DAIRO HERNÁN MESA GRAJALES

\title{
ANÁLISE DOS MECANISMOS DE DANO DE AÇOS INOXIDÁVEIS AUSTENÍTICOS COM ELEVADO TEOR DE NITROGÊNIO DURANTE DESGASTE EROSIVO POR CAVITAÇÃO
}

Tese apresentada à Escola Politécnica da Universidade de São Paulo para obtenção do Título de Doutor em Engenharia Metalúrgica. 


\section{ANÁLISE DOS MECANISMOS DE DANO DE AÇOS INOXIDÁVEIS AUSTENÍTICOS COM ELEVADO TEOR DE NITROGÊNIO DURANTE DESGASTE EROSIVO POR CAVITAÇÃO}

Tese apresentada à Escola Politécnica da Universidade de São Paulo para obtenção do Título de Doutor em Engenharia Metalúrgica.

Área de concentração:

Engenharia Metalúrgica e de Materiais

Orientador:

André Paulo Tschiptschin 
Ficha Catalográfica

, DAIRO HERNÁN MESA GRAJALES

ANÁLISE DOS MECANISMOS DE DANO DE AÇOS INOXIDÁVEIS AUSTENÍTICOS COM ELEVADO TEOR DE NITROGÊNIO DURANTE DESGASTE EROSIVO POR CAVITAÇÃO. São Paulo, 2010. 134 p.

Tese (Doutorado) - Escola Politécnica da Universidade de São Paulo. Departamento de Engenharia Metalúrgica e de Materiais.

1. Aços Inoxidáveis Austeníticos. 2. Nitretação Gasosa em Alta Temperatura. 3. $\quad$ Desgaste por Cavitação. 4. Orientação Cristalográfica. I. Universidade de São Paulo. Escola Politécnica. Departamento de Engenharia Metalúrgica e de Materiais. II. Título. 
A meu filho Juan José por ter chegado na hora certa para alegrar as nossas vidas e a minha esposa Olga Lucía pela sua paciência. 


\section{Agradecimentos}

- Agradeço principalmente a Deus por todas as coisas boas que sempre têm chegado na minha vida.

- Aos meus Pais Octavio e Aurentina (in memoriam) por facilitar a minha presença neste mundo.

- Ao meu colega e amigo Carlos Mario Garzón Ospina por sua infinita paciência e dedicação e pelas orientações sempre acertadas para levar adiante este trabalho.

- Aos meus irmãos e familiares pelas contínuas palavras de apoio.

- À CAPES e COLCIENCIAS - LASPAU pela ajuda financeira para a realização deste trabalho.

- À Universidade Tecnológica de Pereira - Colômbia por acreditar em mim e me outorgar a comissão de estudos.

- Ao Prof. Dr. André Paulo Tschiptschin por me permitir fazer parte do seu grupo de pesquisa e pela confiança e o aprendizado.

- Aos meus companheiros de trabalho na Universidad Tecnológica de Pereira Faculdad de Tecnología e Programa de Tecnología Mecánica, especialmente aos professores Yesid Ortiz e Héctor Álvaro González e à colega Alba Franco.

- Ao meu amigo Jimy Unfried Silgado pelas palavras sempre positivas e pela ajuda para obter algumas das amostras.

- Aos meus amigos Mario González, Anderson Ariza, Wilmar Calderón, James Rodríguez, Daniel Liuz Rodrigues, Alexander Hincapie, Rafael Maia, Vinicius Elias, Paula Silva, Alexandre farina, Julio Klein e Abel Recco pelo apoio incondicional .

- Aos colegas e amigos do LFS. Ao Prof. Dr. Amilton Sinatora por facilitar o uso do equipamento de cavitação e por estar disposto sempre a compartilhar o seu conhecimento e ao Prof. DR. Roberto Martins pelas indicações sempre acertadas. 
- Aos colegas e amigos do Departamento de Engenharia Metalúrgica e de Materiais. 


\section{TRABALHOS GERADOS DURANTE O DOUTORADO}

\subsection{Publicações em periódicos}

1. MESA, G. Dairo. H; GARZÓN, O. Carlos. M; TSCHIPTSCHIN, A. Paulo. Avaliação da resistência ao desgaste erosivo gerado por cavitação em aços inoxidáveis austeníticos com alto teor de nitrogênio: estudo dos mecanismos de desgaste. Revista da Escola de Minas (REM). V. 63. n. 1, p 147-152, 2010.

2. MESA, G. Dairo. H; GARZÓn, O. Carlos. M; TSCHIPTSCHIN, A. Paulo. Mesoscale plasticity anisotropy at the earliest stages of cavitation-erosion damage of a high nitrogen austenitic stainless steel. Wear, v. 267, p. 99$103,2009$.

3. MESA, G. Dairo. H; GARZÓn, O. Carlos. M; TSCHIPTSCHIN, A. Paulo. Estudio del desgaste erosivo por cavitación a nivel del tipo de límites y orientación cristalina de los granos en un acero inoxidable austenítico de alto nitrógeno. Scientia et Technica, v. 41, p. 291-296, 2009.

4. MESA, G. Dairo. H; GARZÓn, O. Carlos. M; TSCHIPTSCHIN, A. Paulo. Uso de la difracción de electrones retro-proyectados-EBSD en el estudio del desgaste erosivo por cavitación de un acero austenítico de alto nitrógeno. Scientia et Technica, v. 39, p. 291-296, 2008.

5. LÓPEZ, Diana. M; TSCHIPTSCHIN; MESA, G. Dairo. H. Efecto del nitrógeno en el desgaste erosivo y corrosivo del acero inoxidable austenítico UNS S30403 (AISI-SAE 304L). Scientia et Technica, v. 1, p. 225-230, 2006.

\subsection{Trabalhos submetidos para publicação}

1. MESA, G. Dairo. H; GARZÓN, O. Carlos. M; TSCHIPTSCHIN, A. Paulo. Estudio del desgaste erosivo por cavitación de un acero austenítico de alto nitrógeno apoyado en el uso de la difracción de electrones retro-proyectadosEBSD. Revista Ingenerie. Chile.

2. MESA, G. Dairo. H; GARZÓn, O. Carlos. M; TSCHIPTSCHIN, A. Paulo. Improvement of the cavitation erosion resistance of uns 31803 stainless steel by duplex treatment. Revista: Surface and Coatings Technology. 


\subsection{Trabalhos publicados em anais de congressos}

1. MESA, G. Dairo. H; GARZÓN, O. Carlos. M; TSCHIPTSCHIN, A. Paulo. Improvement of the cavitation erosion resistance of UNS S 31803 stainless steel by duplex treatment. In: 37th International conference on metallurgical coatings \& thin films (ICMCTF), San Diego-California, USA. Abril 26-30, p35 G6-11, 2010.

2. MESA, G. Dairo. H; GARZÓN, O. Carlos. M; TSCHIPTSCHIN, A. Paulo. Mesoscale plasticity anisotropy at the Earlier stages of erosive damage during cavitation of austenitic stainless steels: the role of the grain boundary character. In: 11 International Conference on Advanced Materials (ICAM-2009), Rio de Janeiro.

3. MESA, G. Dairo. H; GARZÓn, O. Carlos. M; TSCHIPTSCHIN, A. Paulo. Analysis of Cavitation-Erosion Deterioration Mechanisms at the Micrometer Scale in Austenitic High Nitrogen Steels. In: Conference of High Nitrogen Steel (HNS 2009), Moscou: A.G. Svyazhin, V.G. Prokoshkina,, 2009. v. 1. p. 150-155.

4. MESA, G. Dairo. H; GARZÓN, O. Carlos. M; TSCHIPTSCHIN, A. Paulo. Estudio de los mecanismos de desgaste erosivo por cavitación a nivel microestructural en un acero inoxidable austenítico con alto contenido de nitrógen. In: $9^{\circ}$ Congreso Iberoamericano de Ingeniería Mecánica, 2009, Las Palmas de Gran Canaria. Anais $9^{\circ}$ Congreso Iberoamericano de Ingeniería Mecánica. Las Palmas de Gran Canaria-España: Air Express Gran canaria, 2009. v. 1. p. $10-15$.

5. MESA, G. Dairo. H; GARZÓn, O. Carlos. M; TSCHIPTSCHIN, A. Paulo. Meso-anisotropia da deformação plástica e do desgaste durante a erosão por cavitação de um aço austenítico com alto teor de nitrogênio. In: $63^{\circ}$ Congresso Anual da ABM - 2008, 2008, Santos-São Paulo. Anais 63 Congresso Anual da ABM. São Paulo : Associação Brasileira de Metalurgia e Materiais, 2008. v. 1. p. 3704-3712.

6. MESA, G. Dairo. H; GARZÓn, O. Carlos. M; TSCHIPTSCHIN, A. Paulo. Avaliação da resistência ao desgaste erosivo gerado por cavitação em aços inoxidáveis austeníticos com alto teor de nitrogênio: estudo dos mecanismos de desgaste. In: IX Seminário Brasileiro do Aço Inoxidável, 2008, São Paulo. Nucleo Inox, 2008. v. 1. p. 202-209. 


\section{Resumo}

Neste trabalho são estudados os mecanismos de desgaste, atuantes na escala do tamanho de grão (meso-escala), durante ensaios de cavitação vibratória, para diferentes amostras de aços inoxidáveis austeníticos ligados com nitrogênio. Amostras com teores superficiais de nitrogênio de aproximadamente 0,9\%massa, 1,4\%-massa e 20\%-massa, obtidas a partir do aço inoxidável dúplex UNS S31803, foram estudadas.

As amostras do aço inoxidável duplex UNS S31803, com aproximadamente $0,9 \% N$ - massa, foram obtidas por nitretação gasosa em alta temperatura (temperatura de nitretação entre 1050 e $1200{ }^{\circ} \mathrm{C}$ ) e consistiram em três grupos diferentes: amostras com nitrogênio em solução sólida e solubilizadas, amostras com precipitação de nitretos e amostras com nitrogênio em solução sólida e encruadas. Já as amostras com teor de nitrogênio próximo de $20 \% N$ - massa foram processadas por meio de nitretação a plasma na temperatura de $400{ }^{\circ} \mathrm{C}$, obtendo-se uma camada superficial de "austenita expandida".

As amostras de ensaio foram submetidas à caracterização de textura por difração de elétrons retroespalhados, EBSD, e posteriormente à cavitação vibratória em água destilada. Os ensaios de cavitação foram periodicamente interrompidos com o intuito de estudar a deterioração das amostras por exame das mesmas no microscópio eletrônico de varredura, MEV, e por medidas de perda de massa.

Quando comparadas com os aços inoxidáveis austeníticos convencionais (UNS S30403 solubilizado e UNS S31803 como recebido), sem adição de nitrogênio e livre de encruamento, as amostras estudadas apresentaram resistência ao desgaste por cavitação superior, quantificada tanto pelo tempo de incubação do dano com perda de massa quanto pela taxa máxima de perda de massa nos estágios avançados do dano.

A taxa máxima de perda de massa para cada tipo de amostra estudada, com relação à taxa máxima do material de comparação, o aço inoxidável convencional sem adição de nitrogênio e livre de encruamento (UNS S30403) solubilizado, foi de: amostras com precipitação de nitretos (318HTGN+Nit), 6,9 vezes menor; amostras com nitrogênio em solução sólida e solubilizadas (318HTGH+Sol) e laminadas e solubilizadas (318HTGN+Lam+Sol), 26,8 e 25 vezes menor, respectivamente; amostras com nitrogênio em solução sólida e encruadas (318HTGN+Enc) 145 vezes menor; e amostras com camada superficial de austenita expandida (obtidas por nitretação a plasma), (318HTGN+Plas e 304LSol+Plas) 290 e 1,77 e vezes menor respectivamente.

O efeito benéfico da adição de nitrogênio na resistência à erosão por cavitação dos aços inoxidáveis austeníticos estudados foi atribuído a:

(i) aumento na resistência à deformação plástica; 
(ii) distribuição mais homogênea da deformação plástica induzida pelas ondas de choque e micro-jatos característicos do processo de cavitação; e

(iii) aumento da importância relativa dos mecanismos de perda de massa com elevado consumo de energia de impacto.

Nos primeiros estágios do dano erosivo por cavitação se observou clara evidência de deformação plástica, acompanhada de formação de microreelevo superficial e de protrusão de bandas de escorregamento. A perda de massa em nível microscópico (observações no MEV) começa como destacamento de material em microtrincas e micropites.

Observou-se que tanto a nucleação do dano como o seu crescimento se apresenta de forma heterogênea na escala do tamanho de grão.

Os sítios microestruturais nos quais se iniciou o dano com perda de massa foram preferencialmente protuberâncias nas protrusões de bandas de escorregamento, protuberâncias nos contornos de grão e as interfaces matriznitreto.

O incremento do teor de nitrogênio (em solução sólida) na amostra aumentou a importância relativa dos contornos de grão como locais de nucleação do dano, em relação ao dano iniciado no interior dos grãos.

Observou-se que o interior dos grãos com planos 100 ou 111 orientados de forma aproximadamente paralela à superfície das amostras são regiões muito suscetíveis à incubação do dano e ao crescimento do mesmo. Já os grãos com planos 101 orientados aproximadamente paralela à superfície das amostras, apresentam regiões com resistência ao dano bem maior. Esses resultados são discutidos, considerando as diferenças de tensão (resultantes da ação de ondas de choque causadas pela implosão de bolhas de cavitação) crítica projetada para cisalhamento de grãos com diferentes orientações.

O dano ocorre preferencialmente em contornos de grãos com acentuados gradientes de tensão resolvida para a deformação plástica, onde se desenvolve elevada concentração de tensões. Em particular, os contornos de macla CSL $\Sigma-3$ são acentuadamente mais suscetíveis à incubação do dano que os outros tipos de contornos CSL e que os contornos não CSL. 


\section{Abstract}

High nitrogen austenitic stainless steels containing 0.9 wt- $\% \mathrm{~N}$ and $\sim 20$ wt$\% \mathrm{~N}$ were tested in a ultrasonically induced vibratory cavitation testing device. Incubation times for damage initiation and mass losses were periodically measured during the cavitation-erosion tests. Scanning Electron Microscopy observation of the damaged surfaces allowed identifying the wear mechanisms operating during each step of the cavitation-erosion test.

0.9 wt-\% N specimens were obtained through High Temperature Gas Nitriding UNS S31803 duplex stainless steel, at temperatures between 1050 and $1200{ }^{\circ} \mathrm{C}$. Three groups of specimens were obtained: solubilized with all nitrogen in solid solution, solubilized and work hardened specimens and nitride containing specimens. The $\sim 20$ wt- $\% \mathrm{~N}$ specimens were obtained through Low Temperature Plasma Nitriding the already High Temperature Gas Nitrided specimens and getting an expanded austenite layer at the surface.

The specimens were firstly characterized by Electron Backscattered Diffraction - EBSD techniques and then submitted to the cavitation-erosion tests in distilled water. When compared to conventional UNS S30403 lean nitrogen solubilized austenitic stainless steel specimens, greater incubation times and smaller maximum wear rates were observed. The maximum wear rates (compared to those of the solubilized UNS S30403 steel) were: for the nitride containing specimen 6.9 times smaller; for textured and non-textured all nitrogen in solid solution specimens 26.8 and 25 times smaller, respectively; for the solubilized and work hardened specimen 145 times smaller; for the expanded austenite layer, with circa 20 wt- $\% \mathrm{~N}$, specimens 300 times smaller.

The beneficial effect of nitrogen on the cavitation-erosion resistance of the studied specimens was attributed to:

(i) an increase in resistance to plastic deformation;

(ii) a more homogeneous distribution of the plastic deformation; and

(iii) an increase of the relative participation of energy consuming mass loss mechanisms.

Plastic deformation accompanied by formation of micro relief at the surface and slip bands protrusions were clearly identified, during the first stages of cavitation erosion. The first evidences of mass loss (detected by SEM observations) were seen as particles detaching from micro cracks and micro pits formed at the grain surface.

Nucleation and growth of cavitation damage was heterogeneously distributed at the grain scale. Slip bands protrusions, grain boundary protrusions and nitride matrix interfaces sites were more prone to nucleating the damage. 
Increasing nitrogen contents in solid solution increased the relative contribution of grain boundary nucleated damage, compared to the total amount of nucleation sites.

Grains with 100 and 111 crystallographic planes approximately parallel to the surface were more prone to nucleation and growth of cavitation damage. Grains with 101 planes // surface were much more resistant to cavitation-erosion damage. These results are discussed considering differences of critical resolved shear stresses for grains with different orientations.

Cavitation erosion damage occurs preferentially at grain boundaries across which steep stress gradients arise. Particularly, CSL $\Sigma-3$ twin boundaries are much more susceptible to cavitation erosion damage incubation than other types of CSL boundaries and non CSL boundaries. 


\title{
Sumário
}

\section{Lista de Figuras}

\author{
Lista de Tabelas
}

\section{Lista de Abreviaturas e Símbolos}

1 Introdução 1

2 Revisão Bibliográfica 4

2.1 Tribologia ........................ 4

2.2 Introdução ao estudo do desgaste . . . . . . . . . . . . . . . . . . 4

2.2.1 Tipos de desgaste . . . . . . . . . . . . . . 5

2.2.2 Mecanismos de desgaste . . . . . . . . . . . . . 7

2.3 A cavitação . . . . . . . . . . . . . . . . . . . . 10

2.3.1 Desgaste erosivo por cavitação (EC) . . . . . . . . . . . 11

2.4 Deformação plástica . . . . . . . . . . . . . . . . . . . . . . . . 18

2.4.1 Tensão de cisalhamento crítica projetada para escorregamento . . . . . . . . . . . . . . . . 19

2.4.2 Modos de falha presentes durante o desgaste por EC . . . 24

2.4.3 Materiais utilizados em aplicações onde se tem desgaste EC 25

2.5 Aços inoxidáveis . . . . . . . . . . . . . . . . . . 26

2.5.1 Aços inoxidáveis dúplex . . . . . . . . . . . . . 27

2.5.2 Aços inoxidáveis austeníticos . . . . . . . . . . . . . . 29

2.5.3 Aços inoxidáveis com alto teor de nitrogênio (HNS) . . . . 30

2.6 Tratamento termoquímico de nitretação . . . . . . . . . . . . 31 
2.6.1 Nitretação gasosa de aços inoxidáveis em alta temperatura 31

2.6.2 Nitretação por plasma . . . . . . . . . . . . . . 34

2.6.3 Resistência ao desgaste erosivo por EC de aços HNS . . . . 35

2.7 Difração de Elétrons Retroespalhados (EBSD) . . . . . . . . . . 36

2.7.1 Aplicações da técnica EBSD . . . . . . . . . . . . 38

2.7.2 Orientação cristalográfica (análise da textura cristalográfica) 45

3 Objetivos

3.1 Objetivo geral . . . . . . . . . . . . . . . . . . 49

3.2 Objetivos específicos . . . . . . . . . . . . . . . 49

4 Materiais e Métodos $\quad 51$

4.1 Materiais utilizados . . . . . . . . . . . . . . 53

4.1.1 Materiais no estado como recebido . . . . . . . . . 53

4.2 Tratamentos térmicos, termoquímicos e termomecânicos . . . . . . 53

4.2.1 Nitretação gasosa em alta temperatura (HTGN) . . . . . 53

4.2.2 Nitretação gasosa em alta temperatura com o intuito de formar nitretos .................. 57

4.2.3 Nitretação a plasma em baixa temperatura . . . . . . . . 57

4.2.4 Materiais de comparação . . . . . . . . . . . . . 58

4.3 Ensaios de cavitação vibratória . . . . . . . . . . . . . . 60

4.4 Caracterização microestrutural . . . . . . . . . . . . . . . . . 60

4.4 Microscopia óptica . . . . . . . . . . . . . . . 60

4.4.2 Microscopia eletrônica de varredura (MEV) . . . . . . . 61

4.4.3 Análise dos mecanismos de desgaste. . . . . . . . . . . . 62

4.4.4 Difração de elétrons retroespalhados . . . . . . . . . . 62

4.5 Relações entre desgaste erosivo por cavitação e parâmetros cristalográficos ........................ 63

4.5.1 Relação entre desgaste EC, orientação cristalográfica e FT 64 
4.5.2 Relação entre desgaste erosivo por cavitação e tipo de contornos de grão . . . . . . . . . . . . . . . 66

4.5.3 Relação entre orientação cristalográfica, tipo de contornos de grão e Fator de Taylor FT . . . . . . . . . . . . . . 68

\section{Resultados e discussão}

5.1 Caracterização dos materiais em estudo . . . . . . . . . . . . 69

5.1.1 Caracterização dos aços inoxidáveis no estado como recebido 69

5.1.2 Caracterização dos materiais de estudo antes dos ensaios de desgaste por EC . . . . . . . . . . . . . 71

5.2 Análise dos mecanismos de desgaste por EC . . . . . . . . . . . 82

5.2.1 Aços inoxidáveis com estrutura completamente austenítica e solubilizados $($ tipo 1$) \ldots \ldots . . \ldots 83$

5.2.2 Aços inoxidáveis com estrutura completamente austenítica e encruados $($ tipo 2$) \ldots \ldots . \ldots 90$

5.2.3 Aços inoxidáveis com estrutura austenítica contendo dispersão de nitretos (tipo 3 ) . . . . . . . . . . . . . 94

5.2.4 5.2.4. Aços inoxidáveis nitretados a plasma com estrutura de austenita expandida (tipo 4) . . . . . . . . . 96

5.2.5 Materiais de comparação (tipo 5) . . . . . . . . . . . 104

5.3 Relação entre desgaste por EC com aspectos cristalográficos . . 108

5.3.1 Relação entre desgaste EC, orientação cristalográfica e FT 109

5.3.2 Relação entre desgaste erosivo por cavitação e tipos de contornos de grão . . . . . . . . . . . . . . . 116

5.3.3 Relação entre orientação cristalográfica, desgaste EC em contornos de grão e FT . . . . . . . . . . . . . . . . . . . 119

\section{Conclusões}

6.1 Condicionamento da superfície do aço UNS S31803 . . . . . . . 123

6.2 Desempenho do aço UNS S31803 tratado superficialmente em ensaios de Erosão Cavitação . . . . . . . . . . . . . . . . . . . . . 124 
6.3 Das relações entre desgaste por cavitação e características cristalográficas . . . . . . . . . . . . . . . . 125

$\begin{array}{llr}7 & \text { Sugestões para trabalhos futuros } & 126\end{array}$

$\begin{array}{lr}\text { Referências } & 127\end{array}$ 


\section{Lista de Figuras}

2.1 Micrografia MEV mostrando o fenômeno de pulverização na subsuperfície decorrente de ondas de tensão cisalhantes (CHEN et al., 2008). . . . . . . . . . . . . . . . .

2.2 Representação esquemática do fenômeno da cavitação: (a) nucleação e colapso de micro-bolhas emitindo ondas de choque, (b) formação e colapso de microjatos. Adaptado de (STECK; SOMMERFIELD; SCHNEIDER, 2006) _ . . . . . . . . . . . . . 10

2.3 (a) Modelo da deformação de uma micro-bolha e (b) fotografias a cada 2 milissegundos da formação de micro jatos durante a cavitação respectivamente . . . . . . . . . . . . . . . . . . 12

2.4 Esquema de funcionamento de um equipamento de ensaio de cavitação utilizado para ensaios de EC vibratória (ASTM-G32, 2009) 15

2.5 Representação esquemática da fragmentação de grãos e formação de bandas de escorregamento e arranjos celulares de discordâncias para baixas deformações (KESTENBACH, 2003). . . . . . . . . . . 19

2.6 Relações geométricas entre o eixo de tração, plano de escorregamento e direção de escorregamento utilizadas para calcular a tensão de cisalhamento projetada para um monocristal. Adaptação (CALLISTER, 2006) . . . . . . . . . . . . . . 20

2.7 Etapas do processo de desgaste por EC (JEAN; JEAN, 2005) . . . .

2.8 Diagrama de Schaeffler. Efeito dos elementos de liga sobre a estrutura básica de aços inoxidáveis Cr-Ni (BHADESHIA; HONEYCOMBE, 2006) . . . . . . . . . . . . . .

2.9 Sítios intersticiais octaédricos - (i) e tetraédricos (il): (a) na estrutura CFC, (b) na estrutura CCC, (c) tamanho, em nm, dos espaços octaédricos $\left(r_{6}\right)$ e tetraédricos $\left(r_{4}\right)$ no ferro (GAVRILJUK; BERNS, 1999) . . . . . . . . . . . . . . . . 32 
2.10 Principio de funcionamento do EBSD e posicionamento da amostra (a) e principio de formação de padrões de Kikuchi (b)(LEIBNIZInSTITUTE, 2007). . . . . . . . . . . . . . .

2.11 Geração das linhas de Kikuchi a partir dos cones formados pelos elétrons retroespalhados (COURTAS et al., 2006) . . . . . . . 38

2.12 Variação do IC durante uma varredura EBSD (TSL-INC, 2003). . .

2.13 Artifício matemático usado pelo software TSL para re-indexar portos com baixo IC (TSL-INC, 2003) . . . . . . . . . .

2.14 Mapa OIM de distribuição de orientações cristalográficas de um aço inoxidável austenítico (a) e triângulo unitário de referência das cores utilizadas $(\mathrm{b}) . \ldots \ldots \ldots \ldots$

2.15 (a) Mapa OIM mostrando a linha teste através da qual se quer saber a diferença de orientação cristalográfica entre os grãos por onde passa . (b) Perfil de diferença de orientação referente a linha

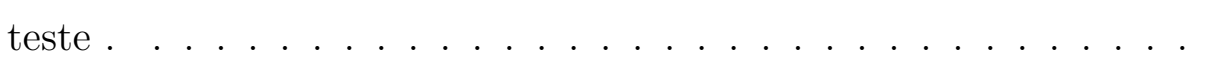

2.16 Formação de uma estrutura local de coincidência CSL (fronteira) (interpenetração teórica) de dois reticulados vizinhos desorientados por $\theta / U V W$, onde $\theta$ e UVW são o ângulo e o eixo de desorientação, respectivamente. (Por simplicidade um limite inclinado é representado) (a). Representação bidimensional do contorno CSL (b) (RANDLE; ENGLER, 2000) . . . . . . . . . .

2.17 Classificação dos contornos de grão em especiais e não especiais no aço $318 H T G N+$ Sol. . . . . . . . . . . . . . . . . . .

2.18 Medição do tamanho de grão, (a) em área, (b) em diâmetro e (c) como distribuição de tamanhos (TSL-INC, 2003) . . . . . . . . .

2.19 Mapa da variação do fator de Taylor (a) em uma amostra carregada em compressão normal ao plano que contém a direção de laminação com sua respectiva escala de valores. (b) mapa OIM. . . . . . . .

2.20 Representação da orientação cristalográfica grão a grão em uma amostra (a) com textura aleatória e (b) texturada (TSL-INC, 2003).

2.21 (a) Componente de textura $\{001\}\langle 110\rangle$ em uma placa e (b) textura de fibra $\{h k l\}\langle 100\rangle$ em uma barra trefilada (CHIN, 1985) . . . . 
2.22 (a) Família de pólos 001 de um cristal cúbico representados em uma projeção estereográfica e (b) família de pólos do cristal (BUNGE.,

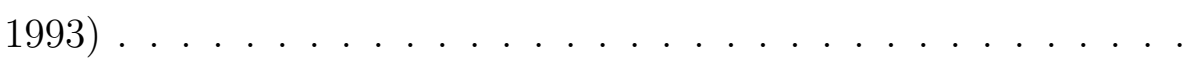

2.23 (a). Figura de pólo inversa obtida através de uma projeção estereográfica (BUNGE., 1993; RANDLE; ENGLER, 2000) . . . . . .

4.1 Equipamento utilizado na realização dos diferentes tratamentos térmicos e termoquímicos. (a) sistema geral, (b) subsistema de entrada de gases e controle da pressão e (c) subsistema de entrada de amostras e manipulação do vácuo. . . . . . . . . . . . .

4.2 Isopletas do diagrama de fases do aço inoxidável UNS S31803, calculado no programa Thermocalc (c). O conjunto de linhas traçadas desde a parte superior esquerda até a parte inferior direita do diagrama corresponde ao equilíbrio com gás $N_{2}$ em diferentes pressões. . . . . . . . . . . . . . . . . . .

4.3 Equipamento de cavitação. (a) vista geral, (b) detalhe do portaamostra, (c) esquema do dispositivo de ensaios. . . . . . . . . . 61

4.4 Área varrida, demarcada sobre a superfície por meio de endentações Vickers. Foto obtida diretamente do programa EBSD antes da varredura da superfície. A área é quadrada mas a amostra está inclinada $70^{\circ}$, daí a sua assimetria. . . . . . . . . . . .

4.5 Esquema de uma chapa onde se mostra a direção de aplicação da tensão para o cálculo do FT. (DL e DN representam as direções de laminação e direção normal à direção de laminação respectivamente). 65

4.6 Para o aço 318HTGN+Lam+Sol: (a) mapa de distribuição de orientações cristalográficas (OIM), (b) área destaca em (a) usada para classificar os tipos de contornos mostrados no mapa à direita

5.1 Micrografias ópticas dos materiais de estudo no estado como recebido, (a) aço inoxidável 304L mostrando grãos austeníticos e (b) aço inoxidável 318 mostrando grãos de austenita e ferrita. Ataque eletrolítico com ácido oxálico $10 \%$ em ambos os materiais.

5.2 (a) micrografia óptica sem ataque do aço inoxidável 304L mostrando inclusões de sulfeto de manganês e (b) espectro EDS confirmado inclusões de sulfeto de manganês. . . . . . . . . . . . 
5.3 Microestrutura do aço inoxidável 318HTGN+Sol. Ataque eletrolítico com ácido oxálico $10 \%$. . . . . . . . . . . . 72

5.4 (a) mapa de distribuição de orientações cristalográficas (OIM) para o aço inoxidável 318HTGN+Sol obtido por EBSD, (b) Figura de pólo inversa IPF. $[\mathrm{TSL} / \mathrm{OIM}] \ldots$. . . . . . . . . . . . . 73

5.5 Micrografia da superfície do aço inoxidável 318HTGN+Lam+Sol. Ataque eletrolítico com ácido oxálico $10 \%$. . . . . . . . . . . 74

5.6 (a) mapa de distribuição de orientações cristalográficas para o aço inoxidável 318HTGN+Lam+Sol obtido por EBSD, (b) Figura de pólo inversa IPF. . . . . . . . . . . . . . . . . . 74

5.7 Microestrutura da superfície do aço 318HTGN+Enc mostrando grãos deformados contendo bandas de cisalhamento grosseiras. Ataque eletrolítico com ácido oxálico $10 \%$. . . . . . . . . 75

5.8 Microestruturas da superfície do aço 318HTGN+Nit: (a) sem ataque, b) atacado eletrolíticamente com ácido oxálico $10 \%$. . . 76

5.9 Para o aço 318HTGN+Nit: (a) mapa de distribuição de orientações cristalográficas, (b) IPF. . . . . . . . . . . . . . . . . 77

5.10 Microestrutura da seção transversal do aço 318HTGN+Plas. (a) microestrutura com núcleo dúplex de austenita e ferrita e superfície de austenita, (b) camada grossa de austenita obtida por nitretação gasosa, e (c) camada fina de austenita expandida obtida por nitretação a plasma. Ataque eletrolítico com ácido oxálico 10 \%.

5.11 Mapa de distribuição de orientações cristalográficas OIM da superfície do aço inoxidável 318HTGN+Plas (b) IPF . . . . . . .

5.12 Para o aço 304LSol+Plas: (a) micrografia com pequenos aumentos após nitretação a plasma, (b) detalhe da região destacada em (a) mostrando a fina camada superficial de austenita expandida. Ataque eletrolítico com ácido oxálico $10 \%$. . . . . . . . . . .

5.13 Microestrutura do aço inoxidável 304LSol. Ataque eletrolítico com ácido oxálico $10 \%$. . . . . . . . . . . . . . . . . . 80

5.14 Mapa de distribuição de orientações cristalográficas OIM da superfície do aço inoxidável 304LSol, (b) IPF. . . . . . . . . . . . 8 
5.15 Microestrutura da superliga de cobalto Stellite-6 no estado como recebida (bruta de fundição). Amostra sem ataque. . . . . . . . . 81

5.16 Perda de massa acumulada em função do tempo de ensaio em experimentos de desgaste EC . . . . . . . . . . . . . . . 82

5.17 Micrografia MEV geral da superfície cavitada por 4 horas para o aço 318 HTGN+Sol. . . . . . . . . . . . . . . . . . . . . . 8

5.18 Micrografias MEV para 4 horas de ensaio de desgaste EC mostrando as regiões de inicio de dano durante o período de incubação do dano para o aço $318 \mathrm{HTGN}+$ Sol. . . . . . . . . . . .

5.19 Micrografias MEV mostrando a evolução do processo de desgaste EC no aço 318HTGN+Sol para (a) 4 h, (b) 9 h, (d) 16 h, (d) 25 h, (e) $36 \mathrm{~h}$ e (f) $64 \mathrm{~h}$ de ensaio de desgaste por EC.

5.20 Micrografia MEV onde é apresentada a aparência superficial da amostra de aço 318HTGN+Sol ensaiada em EC por 49 horas mostrando evidências de desgaste por arranque de micro-plaquetas por fratura frágil .

5.21 Micrografia MEV onde se apresenta a aparência da superfície cavitada no aço 318HTGN+Sol ensaiada por 49 horas mostrando estrias de fadiga, indicativas da ocorrência desse mecanismo de falha. 88

5.22 Micrografia MEV onde se apresentam as regiões de início do dano durante o período de incubação do desgaste EC para o aço 318HTGN+Lam+Sol.

5.23 Micrografias MEV apresentando a evolução do processo de desgaste EC no aço 318HTGN+Lam+Sol para (a) 4 h, (b) 9 h, (d) $16 \mathrm{~h}$, (d) $25 \mathrm{~h}$, (e) $36 \mathrm{~h}$ e (f) $64 \mathrm{~h}$ de ensaio.

5.24 Micrografias MEV do aço 318HTGN+Lam+Sol, onde se mostra (a) o destacamento de material por fratura frágil decorrente da alta deformação plástica sofrida pela superfície, (b) micro-lascamento.

5.25 Micrografia MEV geral do aço 318HTGN+Enc ensaiado em EC por 4 horas em EC. O detalhe (a) mostra o curvamento de alguns contornos devido à deformação e o detalhe (b) mostra micro-pites formados nas incrustações decorrentes do processo de laminação. . 
5.26 Micrografias MEV mostrando a evolução do processo de desgaste EC no aço 318HTGN+Enc para (a) 4 h, (b) 9 h, (c) 16 h, (d) 25 h, (e) $36 \mathrm{~h}$ e (f) $64 \mathrm{~h}$ de ensaio. . . . . . . . . . . . . . . 93

5.27 Micrografias MEV onde se apresenta as regiões de inicio do dano por EC no aço 318HTGN+Nit para (a) 4 horas e (b) 9 horas de ensaio.

5.28 Micrografias MEV mostrando a evolução do processo de desgaste EC para o aço 318HTGN+Nit para: (a) 16 h, (b) 25 h, (c) $36 \mathrm{~h} \mathrm{e}$ (d) $64 \mathrm{~h}$ de ensaio.

5.29 Micrografias MEV para o aço 318HTGN+Nit onde se apresentam: (a) locais de início de dano e (b) evidência de desgaste por fratura frágil decorrente da intensa deformação plástica sofrida pela superfície . . . . . . . . . . . . . . . . . . 9

5.30 Micrografia MEV onde se apresentam os locais de início do dano no aço 318 HTGN+Plas para 4 horas de ensaio por EC. . . . . . .

5.31 Micrografias MEV onde se apresenta a evolução do processo de desgaste no aço 318HTGN+Plas para (a) 4 h, (b) 9 h, (d) 16 h, (d) $25 \mathrm{~h}$, (e) $36 \mathrm{~h} \mathrm{e} \mathrm{(f)} 64 \mathrm{~h}$ de ensaio de desgaste por EC.

5.32 Micrografias MEV para o aço 318HTGN+Plas onde se apresenta: (a) o início e (b) a propagação do dano em contornos altamente resistentes ao desgaste EC. . . . . . . . . . . . . . . . . . . 100

5.33 Micrografias MEV onde se visualizam regiões que mostram o dano por EC no aço 318HTGN+Plas para tempos de ensaio avançados (100h). (a) contornos de grão, interior do grão e (c) e (d) bandas de escorregamento.

5.34 Micrografias MEV onde se apresentam os primeiros sintomas de desgaste no aço 304LSol+Plas ensaiado a EC por 0,5 horas: (a) micrografia geral e (b) micrografia do detalhe mostrado na figura (a)

5.35 Micrografias MEV onde se apresenta o avanço do dano por EC no aço 304LSol+Plas: (a), (b) e (c) micrografias para 3, 6 e 12 horas de ensaio respectivamente, e (d), (e) e (f) detalhes dos destaques mostrados nas figuras (a), (b) e (c) respectivamente. . . . . . . . 103 
5.36 Micrografias MEV apresentando os primeiros sintomas de dano durante o período de incubação no aço 304LSol: (a) aspecto geral da superfície, (b) detalhe da figura (a). . . . . . . . . . . . . . 104

5.37 Micrografias MEV onde se apresenta a evolução do processo de desgaste no aço 304LSol em função do tempo de ensaio de desgaste EC para: (a) 1.5, (b) 3 e (c) 6 horas. (d), (e) e (f) são detalhes de regiões nas superfícies (a), (b) e (c) respectivamente. . . . . . . 106

5.38 Micrografias MEV onde se apresentam os primeiros sintomas de dano na superliga Stellite-6 durante o período de incubação do desgaste por EC para 4 horas de ensaio.

5.39 Micrografia MEV da seção transversal da amostra de Stellite-6 mostrando quebra de carbonetos após ter sido ensaiada em EC por 64 horas.

5.40 Micrografias MEV onde se apresenta a evolução do processo de dano em etapas avançadas do desgaste por EC no Stellite-6: (a), (b) e (c) são micrografias correspondentes a 16, 36 e 49 horas de ensaio de desgaste EC respectivamente; (d), (e) e (f) são detalhes de regiões nas superfícies (a), (b) e (c) respectivamente. . . . . . . .

5.41 Para o aço 318HTGN+Sol, após 4 horas de ensaio de desgaste EC: (a) mapa OIM, (b) micrografia MEV correspondente com o mapa (a), (c) destaque dos grãos mais conservados segundo a micrografia (b), (d) mapa OIM de grãos mais conservados correspondente com a figura (b) e (c)

5.42 Para o aço 318HTGN+Sol após 64 horas de ensaio de desgaste EC: (a) mapa OIM, (b) micrografia MEV correspondente com o mapa da figura (a), (c) destaque dos grãos mais conservados segundo a micrografia (b), (d) mapa OIM de grãos mais conservados correspondente com a figura (b) e (c) . . . . . . . . . . . .

5.43 Para o aço 318HTGN+Sol: (a) mapa de distribuição de orientações cristalográficas OIM, (b) micrografia MEV onde se destacam grãos com orientação 101 paralela à superfície, (c) mapa de distribuição de orientações cristalográficas OIM mostrando grãos isolados com orientação 101 destacados em (b), (d) mapa de FT para tensão de compressão normal à superfície cavitada . . . . . . . . . . . . . . 112 
5.44 Para o aço 318HTGN+Lam+Sol após 64 horas de ensaio de desgaste EC: (a) mapa OIM, (b) micrografia MEV correspondente ao mapa em (a) com grãos 101 destacados, (c) Mapa OIM de contornos mais conservados correspondente com a figura (b), (d) mapa do FT (b) e (c). . . . . . . . . . . . . . . . . . . 113

5.45 (a) Mapa OIM do aço 318HTGN+Lam+Sol de textura aleatória, contendo aproximadamente 100 grãos, usado para classificar o desgaste, (b) IPF correspondente com a figura (a), (c) e (d) são micrografias MEV onde se mostra a intensidade do desgaste para 9 e 25 horas de ensaio de desgaste EC, respectivamente. . . . . . . 114

5.46 Mapas EBSD de grãos para o aço 318HTGN+Lam+Sol em destaque (colunas 1 e 3), com sua respectivas IPFs (colunas 2 e 4), correspondentes as micrografias mostradas nas figuras 5.45 (c) e (d) e usados para avaliar a resistência ao desgaste EC para 9 horas de ensaio (figuras (a) a (e) e 25 horas de ensaio (figuras (f)

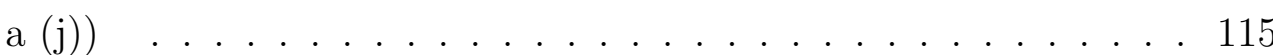

5.47 Para o aço 318HTGN+Lam+Sol apresenta-se mapas de tipos de contornos de grão assim: (a) CSL e Não CSL, (b) contornos CSL $\sum-3$ (maclas), (c) outros CSL utilizados para analisar o desgaste em contornos de grão . . . . . . . . . . . . . . . 117

5.48 Para para o aço 318HTGN+Lam+Sol apresenta-se a superfície da amostra danificada durante o ensaio de desgaste EC. A região analisada é a mesma mapeada na figura 5.50 (a). Identificação e classificação do estado de diferentes tipos de contornos em função do tempo de ensaio EC: (a) 4h de EC: (b) 9h de EC, (c) 16 h de EC e $($ d) 25 h de EC. . . . . . . . . . . . . . . . . . . 118

5.49 Para o aço 318HTGN+Lam+Sol, varição da porcentagem de tipos de contornos de grão danificados em função do tempo de exposição à EC, para contornos de grão especiais e não especiais. . . . . . . 118

5.50 Para o aço 318HTGN+Lam+Sol: (a) micrografia MEV da superfície de uma amostra cavitada 16 h, (b) mapa OIM de orientação cristalográfica, (c) mapa de Taylor para tensão de compressão normal a superfície cavitada. . . . . . . . . . . . . . . 120 
5.51 Diferença do fator de Taylor de grãos separados por contornos conservados para 16 horas de ensaio em experimentos de desgaste EC . . . . . . . . . . . . . . . . . . 121 


\section{Lista de Tabelas}

2.1 Variação percentual do parâmetro de rede do ferro CFC gerada pela adição de N e C; 100 x $(\Delta a \div a o) x \%$-atômica (GAVRILJUK; BERNS, 1999) . . . . . . . . . . . . . . . . . . 32

4.1 Composição química nominal dos aços utilizados. . . . . . . . . 53

4.2 Informações referentes a tratamentos térmicos, termoquímicos e termomecânicos, e características macroestruturais e mecânicas dos materiais utilizados neste trabalho. . . . . . . . . . . . 59

5.1 Tempo de incubação (ti), taxa de desgaste (w) e resistência ao desgaste EC relativa $(\mathrm{mg} / \mathrm{h})$ para todos os materiais utilizados com relação aos materiais 304LSol, 318CR e Stellite-6. . . . . . . 83 


\section{Lista de Abreviaturas e Símbolos}

\section{Abreviaturas}

CFC: Estrutura cristalina cúbica de faces centrada.

EC: Desgaste erosivo por cavitação, erosão cavitação ou erosão por cavitação.

MEV: Microscopia eletrônica de varredura.

EBSD: Difração de elétrons retroespalhados (Electron Backscattering Diffraction).

EDE; Energia de efeito de empilhamento.

IC: Índice de qualidade.

MET: Microscopia eletrônica de transmissão.

$N_{2}$ : Nitrogênio gasoso.

WDS: Espectrometria de raios $\mathrm{X}$ de comprimento de onda dispersiva (Wavelength dispersive X-ray spectroscopy ).

EDS: Espectrometria de raios X de dispersão de energia (Energy Dispersive Xray Spectroscopy).

HTGN: Nitretação gasosa em alta temperatura (High Temperature Gas Nitriding).

318CR: Aço inoxidável UNS S31803 no estado como recebido.

318HTGN+Sol: Aço inoxidável UNS S31803 no estado nitretado a gás e solubilizado.

318HTGN+Lam+Sol: Aço inoxidável UNS S31803 no estado nitretado a gás, laminado e solubilizado.

318HTGN+Enc: Aço inoxidável UNS S31803 no estado nitretado a gás e laminado (encruado). 
318HTGN+Nit: Aço inoxidável UNS S31803 no estado nitretado a gás com precipitação de nitretos de cromo.

318HTGN+Plas: Aço inoxidável UNS S31803 no estado nitretado a gás e depois nitretado a plasma.

304LSol: Aço inoxidável UNS S30403 no estado solubilizado.

304LSol+Plas: Aço inoxidável UNS S30403 no estado solubilizado e nitretado a plasma.

FT: Fator de Taylor.

OIM: Microscopia de imagens de orientação (Orientation Imaging Microscopy).

PMT-EPUSP: Departamento de Engenharia Metalúrgica e de Materiais da Universidade de São Paulo.

EP-USP: Escola Politécnica da Universidade de São Paulo.

HV: Dureza em escala Vickers.

CSL: Reticulado de coincidência (Coincidence site lattice).

Mapa EBSD: Mapa de distribuição de orientações cristalográficas.

IPF: Figura de pólo inversa (Inverse pole figure).

LTPN: Nitretação a plasma em baixa temperatura (Low temperature plasma nitriding).

CBs: Blocos de células de discordâncias ("Cell Blocks"). 
Símbolos 


\section{Introdução}

A cavitação é um tipo de desgaste que afeta grande número de componentes de máquinas e equipamentos submetidos à ação de fluxos, principalmente líquidos, os quais por condições de projeto ou manipulação inadequada podem atingir valores de pressão tão baixos que permitem a geração de bolhas ou cavidades de vapor durante o uso do equipamento. Tais bolhas, quando do retorno da pressão a valores elevados, implodem liberando ondas de choque e micro-jatos de alta energia que são capazes de provocar dano em superfícies sólidas próximas às implosões. Esse tipo de dano é conhecido como desgaste por cavitação ou de erosão por cavitação (EC) pelo fato do dano ser provocado por impacto repetido de múltiplas ondas de choque e micro-jatos.

O desgaste por cavitação é encontrado portanto, em sistemas mecânicos como rotores de bombas, impelidores, turbinas hidráulicas, turbinas de vapor, hélices de barcos, assentos de válvulas entre muitos outros componentes industriais.

Em países da América Latina, onde grande parte da energia elétrica é gerada em usinas hidrelétricas e termoelétricas, este problema tem merecido uma atenção especial, uma vez que há uma grande incidência da cavitação em turbinas hidrelétricas e de vapor.

Os efeitos do desgaste por cavitação vão desde a diminuição da eficiência até a danificação completa dos equipamentos, gerando grandes perdas econômicas.

Levando em consideração o enorme impacto econômico do desgaste erosivo por cavitação, vários estudos têm sido realizados visando minimizar os efeitos deletérios deste fenômeno; seja pela otimização das condições de operação e do projeto dos equipamentos, seja pelo desenvolvimento de materiais avançados e mais resistentes à cavitação. No que diz respeito ao desenvolvimento de novos materiais, na procura de ligas econômica e tecnologicamente mais viáveis, nas últimas décadas, os aços inoxidáveis ligados com nitrogênio (HNS-High Nitrogen Steels) têm-se apresentado como materiais simultaneamente resistentes ao desgaste e à corrosão, particularmente ao desgaste erosivo por cavitação. 
O acentuado efeito benéfico de adições de até aproximadamente 1,0\% em massa de nitrogênio em solução sólida em aços inoxidáveis na resistência à erosão por cavitação tem sido reportado (BERNS; SIEBERT, 1996; QIAO et al., 2007; GAVRILJUK; BERNS, 1999; MESA; GARZÓN; TSCHIPTSCHIN, 2009b), embora o efeito da adição de nitrogênio nos mecanismos de desgaste não tenha sido ainda claramente elucidado.

O efeito benéfico da adição de nitrogênio na resistência à cavitação de aços inoxidáveis pode ser atribuído a:

(i) aumento na resistência à deformação plástica;

(ii) favorecimento de uma distribuição planar e mais homogênea das discordâncias, o que implica em um gasto maior de energia para conseguir movimentá-las durante a deformação plástica; e

(iii) aumento do caráter metálico das ligações atômicas, responsável pela elevada relação limite de escoamento/tenacidade nesses aços.

Por outro lado, o efeito benéfico da diminuição do tamanho de grão sobre a resistência à erosão por cavitação pode ser atribuído ao endurecimento por refino de grão, que leva ao aumento da resistência à deformação plástica e à diminuição da intensidade do micro-relevo gerado na superfície do material por causa da cavitação.

Em investigações realizadas por membros do nosso grupo de trabalho, orientado pelo Prof. Dr. André Paulo Tschiptschin há mais de 10 anos, dentro da linha de pesquisa em propriedades de superfície, foi observado que a adição de nitrogênio em solução sólida realizada em aços inoxidáveis dos tipos dúplex, martensíticos e austeníticos, melhora acentuadamente a resistência à erosão por cavitação, tanto em água destilada quanto em água do mar sintética, onde por meio do controle do teor de nitrogênio, do tamanho de grão, da dureza e da textura cristalográfica é possível diminuir bastante a taxa de perda de massa erosiva por cavitação.

Nesse sentido e buscando avaliar a resistência ao desgaste erosivo por cavitação de aços inoxidáveis dúplex e austeníticos de alto teor de nitrogênio, nitretados a gás em alta temperatura, algumas variações na microestrutura foram utilizadas neste trabalho, com relação a outras condições estudadas pelo grupo em pesquisas anteriores nos mesmos materiais, assim: 
1. Aumentou-se a porcentagem de nitrogênio em solução sólida dentro do aço passando de 0,4\% em média para 0,9\% em massa.

2. Através de tratamentos térmicos como solubilização, tratamentos mecânicos como a deformação a frio e termoquímicos como nitretação gasosa em alta temperatura e nitretação a plasma em baixa temperatura, obtiveram-se vários tipos de aços inoxidáveis austeníticos, com os quais se conseguiu variar a microestrutura dos diferentes materiais, obtendo-se tipos classificados como simplesmente nitretados; nitretados e laminados a frio (encruados); nitretados, laminados a frio e solubilizados; com dispersão de nitretos de cromo e nitretados a plasma.

3. Para efeito de comparação foram usados os aços inoxidáveis duplex UNS S31803 no estado como recebido, o aço inoxidável austenítico UNS S30403 no estado solubilizado e a superliga a base de cobalto Stellite-6 no estado como recebido (bruta de fundição).

Nesses materiais foram estudados os mecanismos de dano envolvidos durante o processo de desgaste por cavitação e a sua relação com aspectos cristalográficos, utilizando técnicas inovadoras como a difração de elétrons retroespalhados EBSD) e técnicas convencionais como a microscopia eletrônica de varredura.

Para alcançar os objetivos deste trabalho, foi realizada uma revisão bibliográfica ampla e abrangente dos temas envolvidos, a qual é apresentada no capítulo 2. No capítulo 3 são apresentados os objetivos do trabalho. No capítulo 4 são descritas as técnicas, processos e equipamentos utilizados para estudar o comportamento frente ao desgaste dos diferentes materiais, este capitulo é intitulado materiais e métodos. No capítulo 5 são apresentados os resultados e as análises de resultados. Finalmente nos capítulos 6 e 7 são apresentadas as conclusões do trabalho e as sugestões para trabalhos futuros respectivamente. 


\section{Revisão Bibliográfica}

\subsection{Tribologia}

A tribologia é uma ciência que apoiada nos princípios da mecânica clássica se encarrega de estudar a relação entre desgaste, atrito e lubrificação e a forma como estes fenômenos levam à deterioração de peças e equipamentos industriais. Para cumprir seu propósito, a tribologia une-se a várias disciplinas como a física, a química, às engenharias: mecânica, de materiais, entre outras, dando lugar a uma nova área de estudo conhecida como engenharia de superfícies (ZUM-GAHR, 1987; HUTCHINGS, 1992)

No que diz respeito ao desgaste, este é um fenômeno conhecido desde a pré-história, quando o homem pré-histórico começou a utilizar elementos naturais como ferramentas e utensílios domésticos. Na atualidade o desgaste, da mesma forma que a corrosão e a fadiga, são temas bastante estudados, por serem as formas mais importantes de degradação de componentes mecânicos e equipamentos industriais (SINATORA, 1997).

\subsection{Introdução ao estudo do desgaste}

Em termos gerais, o desgaste pode ser definido como o dano superficial sofrido pelos materiais após serem submetidos a determinadas condições de trabalho (ASTM-G40, 2010). Nesse sentido, o dano causado pelo desgaste se manifesta de uma forma geral nas superfícies dos materiais, chegando a afetar regiões subsuperficiais. Como resultado tem-se a perda ou deslocamento de material, o que conduz a uma alteração nas dimensões das peças, com a subsequente perda de tolerâncias. De fato, quase todas as máquinas têm diminuída sua vida útil e sua confiabilidade devido ao desgaste. Logo, o controle deste fenômeno é uma necessidade para o desenvolvimento e confiabilidade da tecnologia. 
Os metais podem degradar-se de diferentes formas como consequência das solicitações a que forem submetidos, no entanto, o meio ambiente circundante pode contribuir para acelerar ou retardar o processo de dano. As solicitações às quais um material está submetido variam segundo a forma como o material interage com outros materiais, conhecidos como contra-corpos, e com o meio circundante, seja este sólido, líquido ou gasoso. O conjunto formado entre os materiais que estão se degradando e o meio circundante, e que participa do processo de dano, é conhecido como tribosistema (HUTCHINGS, 1992; BHUSHAN, 1999; ASM-HANDBOOK-VOL-18, 1992).

As taxas de desgaste em um material podem variar no intervalo de $10^{-15}$ a $10^{-1} \mathrm{~mm}^{3} / N . m$, em decorrência do projeto, das condições de operação e dos materiais utilizados, portanto estes parâmetros devem ser considerados elementos chave quando se deseja controlar o desgaste. (ARCHARD, 1953; RABINOWICZ, 1980; BHUSHAN, 1999).

\subsubsection{Tipos de desgaste}

O processo de desgaste pode ser dividido em vários tipos em decorrência das solicitações às quais um material pode estar submetido e dos mecanismos de desgaste que atuam em cada caso. Vários critérios têm sido adotados para classificar o desgaste, por exemplo:

(1) Segundo o movimento relativo entre os corpos que compõem o tribosistema: neste caso, o desgaste é classificado como desgaste por deslizamento, por movimento alternativo "fretting"; por rolamento (ou fadiga de contato), por impacto ou por fluxo (erosão).

(2) Segundo a interação entre os diferentes corpos do tribosistema têm-se: o desgaste por interação sólido com sólido (o mais comum), sólido com líquido ou sólido com gás.

(3) Da situação da interface, ou seja, desgaste a seco ou lubrificado. e

(4) em função dos mecanismos de remoção de material operantes (HUTCHINGS, 1992; BHUSHAN, 1999; PETERSON; WINER, 1980; ASM-HANDBOOK-VOL-18, 1992). 
O tema relacionado com mecanismos de desgaste será discutido detalhadamente a seguir.

Todos os termos apresentados anteriormente são úteis para descrever o tipo de movimento entre superfícies, o que resulta em desgaste, mas eles não descrevem possíveis mecanismos de desgaste pelos quais o dano se apresenta.

A tabela 2.1 mostra um resumo dos diferentes tipos de desgaste e de algumas condições para que este ocorra. Na mesma tabela são apresentados também desenhos representando os diferentes tipos de desgaste, onde se misturam os vários critérios de classificação mencionados.

Classificação dos diferentes tipos de desgaste segundo o estado físico do contra-corpo e do tipo de movimento relativo entre elas. A tabela apresenta também o nome comum desses tipos de desgaste e esquemas do movimento dos corpos envolvidos (PETERSON; WINER, 1980).

\begin{tabular}{|c|c|c|c|}
\hline $\begin{array}{l}\text { Estado físico do } \\
\text { contra-corpo }\end{array}$ & Movimento & Nome Comum & $\begin{array}{l}\text { Desenho represen- } \\
\text { tativo }\end{array}$ \\
\hline \multirow{5}{*}{ Sólido } & Deslizamento & $\begin{array}{l}\text { Desgaste por deslizamento } \\
\text { a seco }\end{array}$ & \\
\hline & Alternativo & Fretting & \\
\hline & Impacto & Desgaste por Impacto & \\
\hline & Rodadura & Desgaste por Rolamento & \\
\hline & $\begin{array}{l}\text { Deslizamento de } \\
\text { partículas }\end{array}$ & $\begin{array}{l}\text { Desgaste Abrasivo a Dois } \\
\text { Corpos }\end{array}$ & \\
\hline $\begin{array}{l}\text { Gás ou Líquido, } \\
\text { Sólido }\end{array}$ & Fluxo & Erosão & $\stackrel{\approx \approx}{\approx}$ \\
\hline Sólido & $\begin{array}{l}\text { Deslizamento ou } \\
\text { Rolamento }\end{array}$ & $\begin{array}{l}\text { Desgaste Abrasivo a Três } \\
\text { Corpos }\end{array}$ & \\
\hline Líquido & Fluxo & Cavitação & 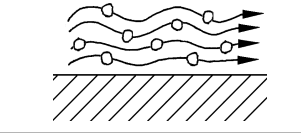 \\
\hline
\end{tabular}




\subsubsection{Mecanismos de desgaste}

Denomina-se mecanismo de desgaste o conjunto de fenômenos físicos e físicoquímicos que fazem com que uma superfície perca material ou se deforme. Os mecanismos de desgaste atuam quando a superfície é submetida a algum dos tipos de desgaste anteriormente mencionados devido ao movimento relativo entre ela e o corpo ou substancia com quem está em contato (ASTM-G40, 2010).

Há casos em que o termo "mecanismo de desgaste"é confundido com o termo tipo de desgaste, e em determinadas ocasiões se usa o mesmo termo para identificar tanto o tipo de desgaste quanto o mecanismo de remoção de material. Tal é o caso da abrasão e da adesão, estes termos definem tanto tipos quanto mecanismos de desgaste.

Os termos desgaste mecânico, desgaste químico e desgaste térmico são usados frequentemente para descrever mecanismos de desgaste presentes durante a ocorrência de dano nas superfícies.

Durante o desgaste mecânico atuam principalmente os mecanismos de deformação plástica, próprio de materiais dúcteis; de fratura, próprio de materiais frágeis e a fadiga, que normalmente é considerada de baixo ciclo (RICHMAN; MCNAUGHTON, 1990; AHMED; HOKKIRIGAWA; OBA, 1994). Com relação ao desgaste químico, este envolve principalmente o mecanismo de crescimento de filmes provenientes de reações químicas ou de processos difusivos. Esses dois mecanismos são conhecidos como reação tribo-química e difusão de espécies químicas respectivamente. Já o desgaste térmico apresenta como principal mecanismo de desgaste a fusão localizada devida ao calor gerado pelo atrito, a qual causa adesão de material na superfície que age como contra-corpo (GWIDON, 2006).

Deve-se deixar claro que em uma superfície podem estar agindo mais de um mecanismo de desgaste ao mesmo tempo, e também que uma superfície pode começar a se degradar através de um tipo de mecanismo e terminar com outro ou outros mecanismos diferentes (BHUSHAN, 1999). Por exemplo, no tipo de desgaste conhecido como erosão por cavitação ou simplesmente erosão cavitação (EC), as superfícies começam a se degradar por deformação plástica, depois ocorre uma mudança de mecanismo e o dano começa a ser controlado por fadiga de baixo ciclo, onde começam a aparecer micro-trincas, que finalmente se unem causando desprendimento de partículas de desgaste por fratura "debris". Neste tipo de desgaste é comum encontrar outros mecanismos de dano causados por efeitos 
térmicos, como a formação de pites térmicos nos pontos da superfície atingida por uma onda de choque que causa um incremento local da temperatura (LIU et al., 2009; HEATHCOCK; BALL; PROTHEROE, 1982; ZHOU; HAMMITT, 1983; WANTANG; YANGZENG; XIAOKUI, 2001). Além dos pites térmicos, outros dois tipos de pites são encontrados nas superfícies submetidas a EC durante o período de incubação do dano, sendo estes os pites completos e incompletos. Chen e Liu (CHEN; LIU, 2009) estudaram os três tipos de pites e concluíram que os micro-jatos, as ondas de choque e as altas temperaturas geradas durante a cavitação, e que atingem as superfícies sólidas, são os parâmetros responsáveis pela aparição dos pites completos, incompletos e térmicos respectivamente.

Em trabalhos recentes, Chen e outros pesquisadores (CHEN et al., 2008) discutiram o fato que o dano nas superfícies submetidas a desgaste EC é causado pela presença de ondas de tensão hiper-velozes, geradas e transferidas por impacto para o sólido durante a implosão de bolhas de cavitação. Estas ondas de tensão provocam deformação plástica no período de incubação do dano, confirmada pela presença de protuberâncias e crateras nas superfícies nos primeiros instantes da EC. Tais ondas de tensão podem ter um efeito cisalhante responsável pela presença das crateras na superfície quando o limite de escoamento é ultrapassado.

Os impactos hiper-velozes das ondas de tensão fazem com que materiais dúcteis falhem por fratura frágil sob a ação de tensões cisalhantes, fato verificado a partir de micrografias MEV, onde foram observadas superfícies de fratura brilhantes e intergranulares sem aparente deformação plástica (CHEN; LIU, 2009) - Estes pesquisadores conseguiram mostrar também que as ondas de tensão afetam a subsuperfície de maneira mais forte do que a superfície devido ao rápido amolecimento dessas regiões. Nas micrografias MEV realizadas na subsuperfície, foi encontrado um tipo de desgaste que foi chamado de pulverização dos grãos, porém é um fenômeno que tem sido pouco estudado. Uma micrografia MEV mostrando a pulverização da subsuperfície é mostrada na figura 2.1.

As ondas de tensão descritas por Chen (CHEN; LIU, 2009) foram classificadas em: 1) ondas de corpo, as quais podem ser de tipo compressivas ou cisalhantes e se propagam radialmente de forma hemisférica a partir da fonte que as produz; e 2) ondas de Raileigh ou superficiais , que se propagam também de forma radial a partir da fonte, porém com formato cilíndrico.

Como conclusões do modelo das ondas de tensão proposto por Chen (CHEN; LIU, 2009), tem-se que a deformação plástica não é a única forma dessas ondas produzirem dano nas superfícies no período de incubação da EC; fratura frágil, 


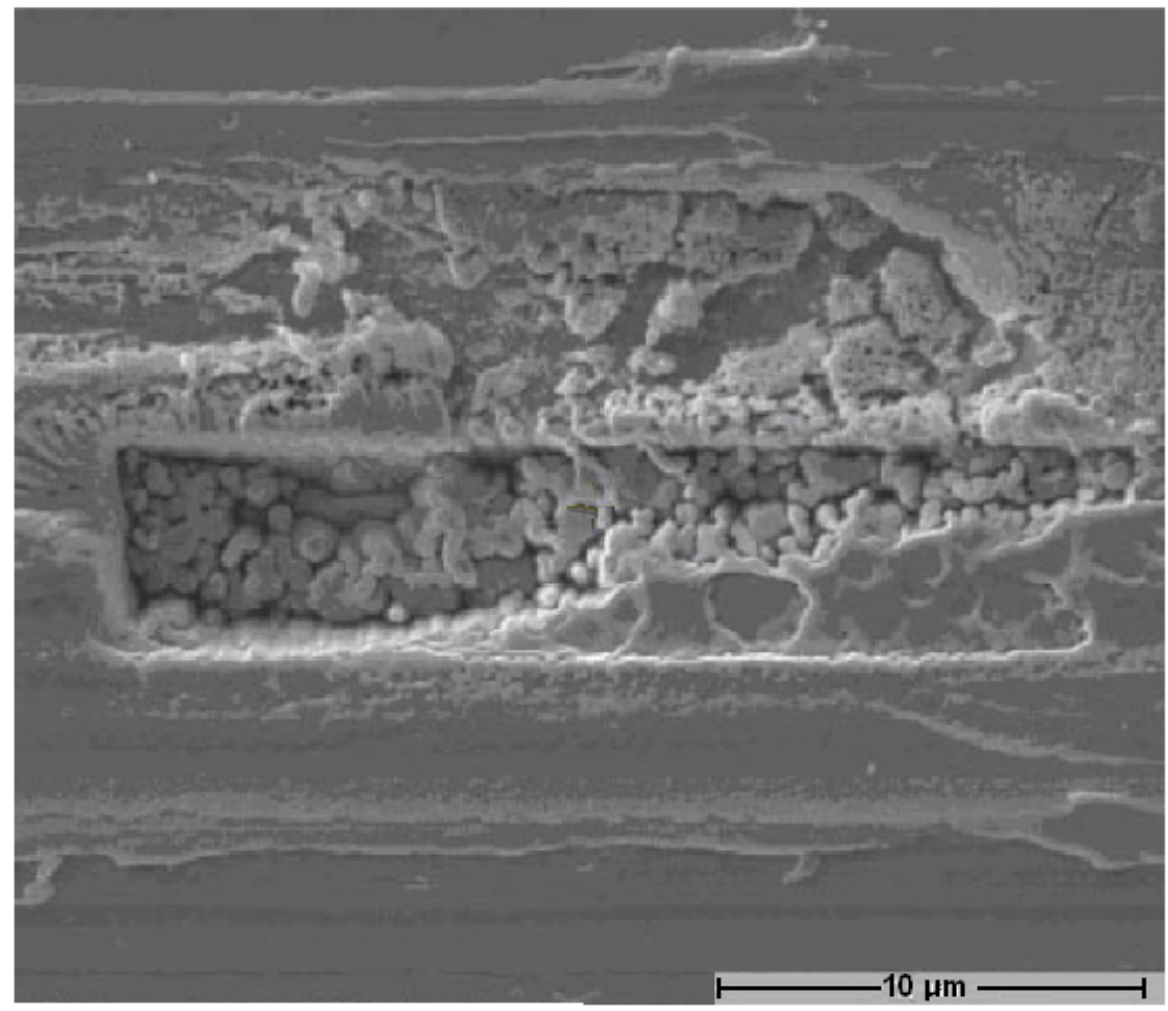

Figura 2.1: Micrografia MEV mostrando o fenômeno de pulverização na subsuperfície decorrente de ondas de tensão cisalhantes (CHEN et al., 2008).

provocada pelas ondas de tipo cisalhante, também acontece neste período sob impacto ultraveloz, o que é verificado pela presença de danos especiais, como a fratura intergranular e a pulverização da subsuperfície da amostra.

Em conformidade com o modelo de ondas de tensão em um material elastoplástico, pode-se pensar que a deformação é causada quando a pressão exercida pelo impacto ultrapassa o limite de escoamento do material, enquanto que a fratura é originada a partir das trincas intergranulares nos contornos de grão geradas pelas ondas de tipo cisalhante.

No caso dos aços inoxidáveis austeníticos convencionais, o mecanismo de deformação plástica durante o período de incubação, é típico de ligas com baixa energia de defeito de empilhamento (EDE). Esta baixa energia evita a recombinação de discordâncias parciais necessárias para que aconteça escorregamento com desvio (Cross Slip). Portanto o mecanismo predominante é por deformação planar. Isso resulta em uma menor interação entre e as discordâncias e os contornos dos grãos, fazendo com que contornos de macla constituam grandes barreiras para a movimentação de discordâncias, daí a formação de degraus nesses contornos de macla (HEATHCOCK; BALL; PROTHEROE, 1982).

Por ser o desgaste EC o tema central deste trabalho, na sequência será feita 
uma revisão detalhada deste tipo de desgaste, onde se discutem os principais mecanismos que atuam durante a remoção de material.

\subsection{A cavitação}

A cavitação é um fenômeno muito comum em sistemas hidráulicos, sendo responsável por grandes custos de manutenção como consequência do grande dano provocado em equipamentos e peças envolvidas no transporte de fluidos.

A cavitação ocorre quando bolhas ou cavidades de vapor são nucleadas dentro de um fluido devido a quedas repentinas de pressão. Estas quedas podem alcançar valores tão baixos, permitindo que parte do fluido atinja a sua pressão de vapor, inclusive à temperatura ambiente, nucleando bolhas de vapor. As bolhas são levadas pelo fluxo e quando alcançam regiões de maior pressão sofrem um colapso violento (implosão), em um tempo muito curto (da ordem de milissegundos), liberando ondas de choque e micro-jatos altamente energéticos. Estes jatos e ondas de choque geram altas tensões mecânicas, da ordem de 1,5 GPa, provocando uma elevação da temperatura da ordem de $1000{ }^{\circ} \mathrm{C}$, de maneira localizada em pontos específicos das superfícies impactadas. Esses dois fenômenos, isto é, as elevadas pressões e temperaturas, ao acontecerem na superfície sólida, provocam a deterioração como mostrado esquematicamente na figura 2.2 (GWIDON, 2006; RAYLEIGH, 1917; SINATORA, 2000; ASTM-G40, 2010).

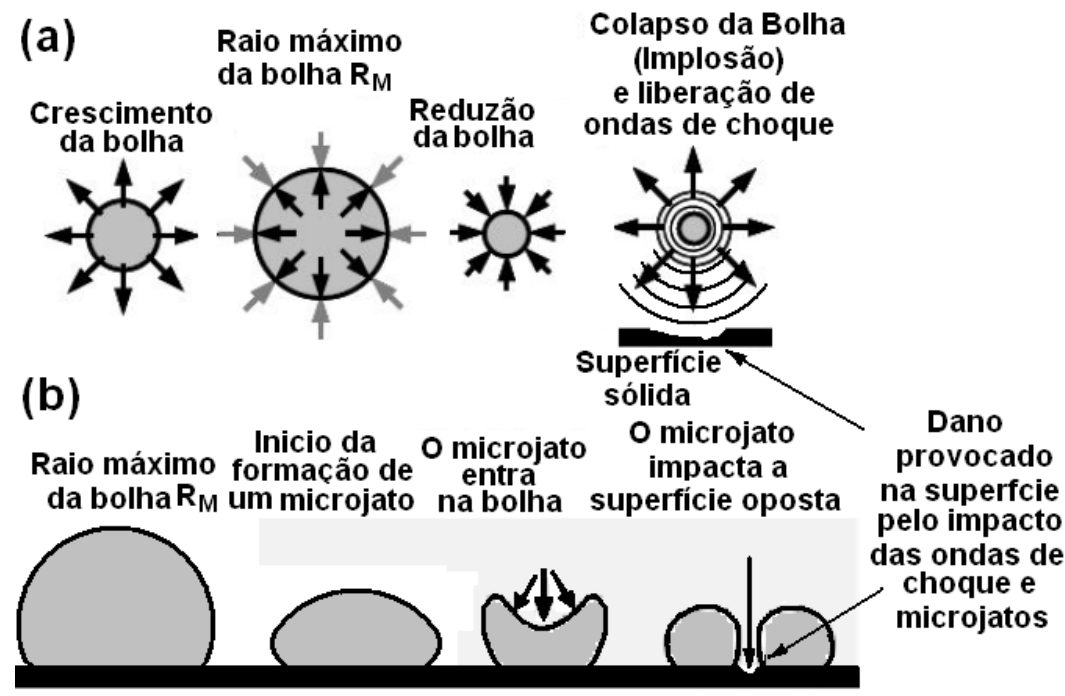

Figura 2.2: Representação esquemática do fenômeno da cavitação: (a) nucleação e colapso de micro-bolhas emitindo ondas de choque, (b) formação e colapso de microjatos. Adaptado de (STECK; SOMMERFIELD; SCHNEIDER, 2006)

A queda de pressão capaz de nuclear bolhas de cavitação pode aparecer 
quando o fluxo de fluido entra em uma geometria divergente, isto é, quando por exemplo, um líquido que atravessa um tubo de diâmetro menor de repente é obrigado a continuar seu percurso através de uma porção do tubo com maior diâmetro. Outro caso típico de formação de bolhas dentro de um fluido é quando um objeto com bordas agudas encontra-se em movimento dentro de um fluido, por exemplo, as hélices de um navio. Essas bordas são particularmente propensas a sofrer desgaste por EC. Dessa forma, um método ideal para prevenir o desgaste é evitar pressões negativas perto das superfícies, coisa que na prática é quase impossível.

Exemplos típicos de equipamentos e peças mecânicas que sofrem desgaste por EC são: hélices de embarcações, bombas e turbinas hidráulicas, pás de turbinas de vapor, superfícies de tubulações, entre muitas outras. Sendo assim, em países como o Brasil e a Colômbia, onde grande parte da energia elétrica é gerada em usinas hidrelétricas, este problema tem merecido uma atenção especial, uma vez que há uma grande incidência da EC neste tipo de indústria. (SINATORA, 1997; CALAINHO et al., 1999).

\subsubsection{Desgaste erosivo por cavitação (EC)}

Segundo a norma ASTM-G40 (ASTM-G40, 2010) denomina-se desgaste erosivo por cavitação (EC) ou cavitação erosão à perda progressiva de material sofrida por uma superfície sólida devido à continua exposição desta à cavitação.

Nesse sentido, quando uma superfície sólida é atingida pelo impacto de partículas, quer sejam, sólidas, líquidas ou gasosas, se diz que o dano provocado por elas é do tipo erosivo. Este é o caso da cavitação, em que mecanismos hidrodinâmicos como ondas de choque e micro-jatos, formados durante a implosão das bolhas de vapor na corrente de escoamento, ao atingirem superfícies sólidas provocam um tipo de desgaste conhecido como desgaste erosivo por cavitação ou simplesmente erosão por cavitação EC (HUTCHINGS, 1992; BHUSHAN, 1999; JEAN; JEAN, 2005).

A erosão das superfícies durante a cavitação é devida à concentração de energia mecânica em áreas muito pequenas das paredes, em consequência do colapso de bolhas de vapor. Essa concentração de energia resulta em níveis de tensão muito altos que podem exceder os limites de resistência do material, isto é, o limite de escoamento e o limite de resistência. O conhecimento da resposta do material a esse micro-bombardeamento, devido ao colapso de milhares bolhas de vapor, constitui ponto chave da mecânica do contínuo, da física dos sólidos e da 
metalurgia para o entendimento do fenômeno de erosão cavitação (JEAN; JEAN, 2005) .

\subsubsection{Mecanismos hidrodinâmicos causadores de dano durante a cavitação}

Como discutido acima, as ondas de choque e os micro-jatos provenientes da implosão de bolhas de cavitação são considerados responsáveis pela deterioração das superfícies sólidas. (RAYLEIGH, 1917; JEAN; JEAN, 2005; CHEN et al., 2008). Rayleigh em seu trabalho sobre cavitação, utilizou um balanço de energia para mostrar a possibilidade do surgimento de altas pressões originadas no colapso de bolhas de cavitação. No estudo, Rayleigh considerou uma bolha imutavelmente esférica, nucleada dentro de um fluido incompressível, não viscoso, em que a pressão interna da bolha fosse desprezível. Embora esta seja uma boa consideração, o modelo falha devido às suas próprias simplificações, já que na realidade todos os fluidos são viscosos e compressíveis e sempre existirá uma determinada quantidade de ar ou gás dissolvido, tanto no líquido quanto no interior da bolha, devido a sua própria nucleação; e mais ainda, as micro-bolhas não mantêm a sua simetria esférica, como mostrado nas imagens da figura 2.3(b) para intervalos de tempo de 2 milissegundos. Esses fatores todos, considerados por Rayleigh como sendo desprezíveis, atuam na realidade como mecanismos de dissipação de energia durante a implosão de uma bolha de cavitação.

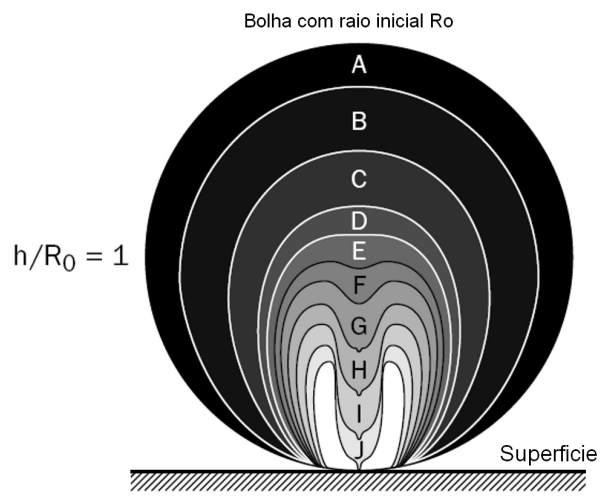

(a)

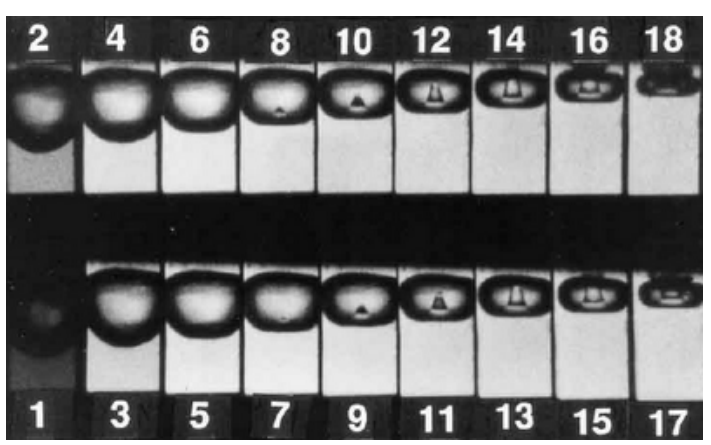

(b)

Figura 2.3: (a) Modelo da deformação de uma micro-bolha e (b) fotografias a cada 2 milissegundos da formação de micro jatos durante a cavitação respectivamente (TOMITA; SHIMA, 1990)

A dissipação de energia ocorre em virtude da viscosidade do fluido, que de maneira geral, pode ser considerado como um fator de amortecimento, transformando a energia mecânica do colapso em energia térmica e em som. (JEAN; JEAN, 2005). A viscosidade também diminui o crescimento do colapso 
das micro-bolhas, reduzindo com isto o dano potencial. A compressibilidade do líquido tem grande influência na formação das ondas de choque na fase seguinte ao colapso. A compressibilidade do líquido tem grande influência na formação e emissão das ondas de choque na fase seguinte ao colapso, causando sua atenuação e diminuindo o dano total provocado.

Para que as ondas de choque possam provocar dano a um material, é necessário que o colapso ocorra muito próximo das superfícies sólidas. Quando o colapso ocorre o fluxo é alterado, dando origem a um segundo mecanismo de dano possível, os micro-jatos.

Quando o colapso da bolha ocorre perto de uma superfície sólida, o fluxo na região entre a superfície e a bolha é restrito. Assim, a velocidade de contração da bolha nessa região é menor do que em regiões onde as bolhas estão mais distantes da superfície sólida. Esta diferença na velocidade de contração provoca uma assimetria do colapso, o que explica a sua forma não esférica. Um modelo apresentando o comportamento da perda da esfericidade de bolhas de cavitação pode ser visto na figura 2.3 (a), em que h representa a distância entre o centro da bolha e a superfície sólida e $R_{0}$ o raio da bolha.

Para validar estas hipóteses, Shima e Tomita (SHIMA; TOMITA; OHSAWA, 1983), usando uma câmera de alta velocidade, fotografaram uma sequência de bolhas formadas dentro de um fluido perto de uma superfície sólida nessa sequência de fotografias apresentadas na figura 2.3(b), eles conseguiram demonstrar a formação de micro-jatos a partir de bolhas em processo de cavitação.

Um micro-jato é produzido quando bolhas de vapor dentro de um fluido implodem sob condições não simétricas, impactando as superfícies, caso seja formado muito perto delas. Os micro-jatos atingem velocidades normais à superfície $(\mathrm{Vj})$ de até $100 \mathrm{~m} / \mathrm{s}$, fazendo com que a pressão no local de impacto aumente muito. $\mathrm{O}$ aumento de pressão $(\Delta p)$ no local de impacto pode ser estimado com ajuda da equação de JOUKOWSKI e ALLIEVI (ARRIS; ALEXANDER, 2009). Isto é:

$$
\Delta p=\rho c V j
$$

onde: c: é a velocidade do som no fluido considerado; e $\rho$ : Densidade do fluido.

Os valores de pressão causados pelos micro-jatos nas superfícies sólidas são 
da ordem de $150 \mathrm{MPa}$ na água. A duração desses pulsos de pressão varia em função do diâmetro $(d)$ da bolha no momento da implosão, sendo esse tempo da ordem de $d / 2 c$, assim, por exemplo, para uma bolha de diâmetro $1 \mathrm{~mm}$, o pulso de pressão exercido pelo micro-jato é da ordem de $0,03 \mu \mathrm{s}$, aumentando na medida que o tamanho da bolha aumenta (JEAN; JEAN, 2005).

A questão de se o dano durante a cavitação é causada pelas ondas de choque ou pelos micro-jatos é um assunto ainda em discussão pelos pesquisadores. Durante os anos 40 e 50, acreditava-se que as ondas de choque eram o mecanismo responsável pelo dano, porém com a descoberta dos micro-jatos, a atenção se voltou para as pressões geradas por estes. Contudo, a questão continua sem se resolver e a posição atual ainda é de que o dano seja causado por uma combinação destes dois mecanismos.

\subsubsection{Resistência à erosão por cavitação:}

Como meio de se estimar a resistência à EC de materiais de engenharia, são realizados ensaios em laboratório utilizando diferentes tipos de dispositivos (cavitômetros), sendo o mais comum o de cavitação vibratória, considerado na norma ASTM-G32/09 (ASTM-G32, 2009). Entretanto, outros aparelhos como tubos venturi, são regularmente utilizados para induzir o desgaste. O objetivo principal desses ensaios é classificar materiais de acordo com a sua resistência à EC, e fazer uma correlação com as propriedades mecânicas clássicas, como dureza, resistência à fluência, elasticidade, resistência à tração, energia de deformação, entre outras.

Em relação ao ensaio da cavitação vibratória, o mesmo induz um desgaste erosivo por cavitação EC na superfície de uma amostra através de uma haste (Horn) que vibra em alta frequência e está imersa no líquido de ensaio (geralmente água). Um esquema apresentado o equipamento de ensaio de desgaste por EC, juntamente com suas partes principais é mostrado na figura 2.4.

A vibração da ponta da haste do equipamento de cavitação, que é a própria amostra no método direto, induz a formação e colapso de bolhas de vapor dentro do líquido, que ao colapsarem produzem o dano (perda de material) na superfície do corpo de prova. Porém, o método de cavitação vibratório permite posicionar o corpo de prova (método indireto) abaixo da ponta vibratória do aparelho, a uma determinada distância, de forma estática. 


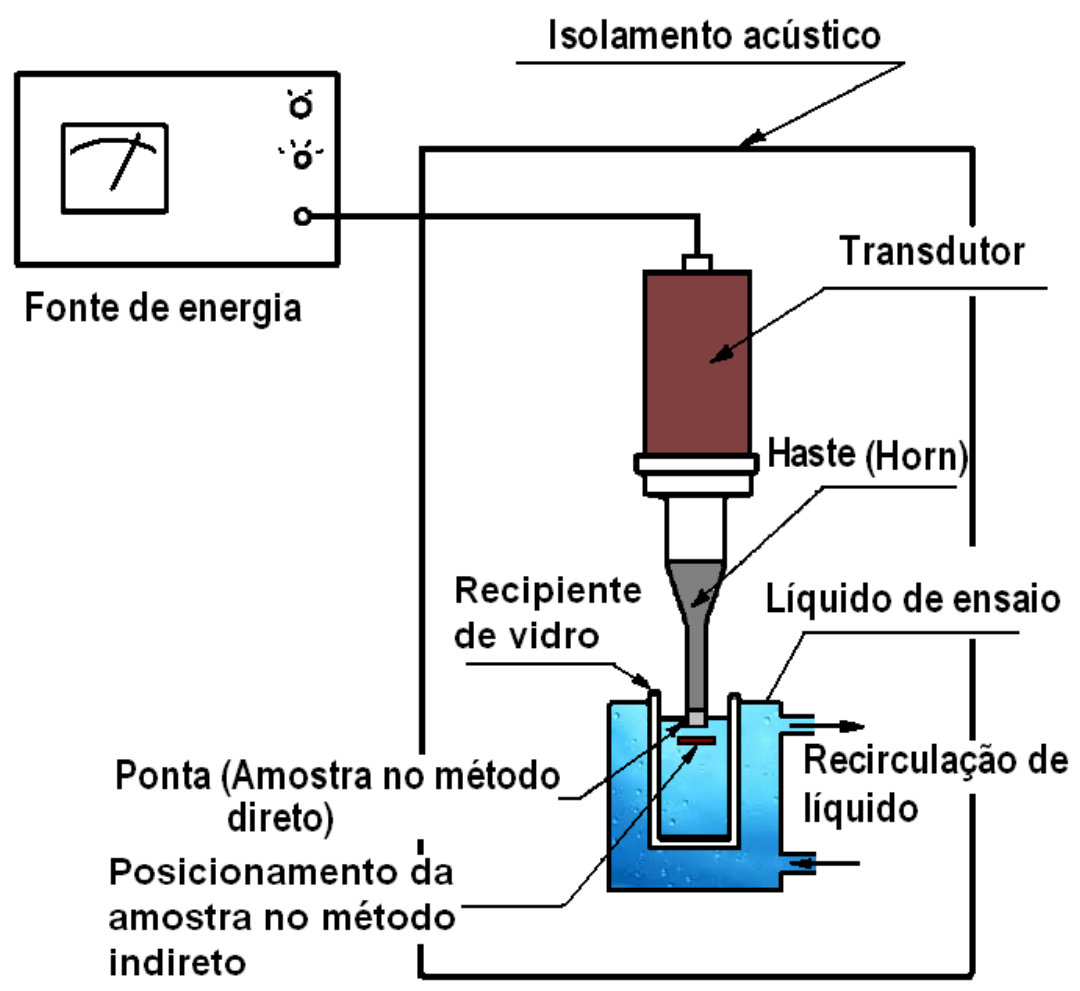

Figura 2.4: Esquema de funcionamento de um equipamento de ensaio de cavitação utilizado para ensaios de EC vibratória (ASTM-G32, 2009) mostrando o posicionamento da amostra no método indireto.

Embora a forma de geração do desgaste EC causado pelo fluido seja diferente da forma como ocorre em sistemas de fluxo e máquinas hidráulicas reais, a natureza dos mecanismos de dano é muito semelhante. Dessa forma, o método oferece um teste relativamente simples e controlável que pode ser usado para comparar a resistência à EC de diferentes materiais.

Entretanto, têm sido os diferentes métodos empíricos desenvolvidos ao longo dos anos e a experiência em máquinas industriais reais, o que tem permitido aos projetistas escolher o material adequado para cada situação industrial e obter uma visão global sobre a influência dos principais parâmetros que governam o processo de EC. Porém, existe ainda uma boa quantidade de problemas a serem resolvidos; envolvendo aspectos relacionados com os materiais, o projeto dos equipamentos e variáveis relacionadas com o ambiente de trabalho.

Dessa forma, correlações entre a resistência à EC de materiais com suas propriedades mecânicas são geralmente muito dispersas e válidas somente dentro de uma gama limitada de parâmetros do escoamento, tais como a velocidade do líquido e do número de cavitação (parâmetro adimensional muito utilizado por projetistas que relaciona propriedades dinâmicas do fluxo, como pressões e temperaturas, para conhecer as velocidades permitidas dentro do fluxo e diminuir problemas de EC), bem como para grupos restritos de materiais. 


\subsubsection{Tensões atuantes em superfícies submetidas ao desgaste EC:}

Tensões presentes na superfície durante o processo de EC são muito difíceis de medir e quantificar, pois o estado de tensões é complexo (estado tri-axial de tensões), e as forças que atuam nas superfícies, derivadas das ondas de choque e micro-jatos formados a partir da implosão de bolhas de vapor, dependem de aspectos tanto hidrodinâmicos, como velocidade, pressão e temperatura do fluido, quanto das propriedades do material, como o limite de escoamento, limite de resistência, tenacidade à fratura, etc. Uma dificuldade adicional para medir as tensões durante a EC está no fato de que nem todas as bolhas formadas no fluido têm o mesmo tamanho e a mesma pressão interna e nem todas estão à mesma distância da superfície afetada.

Um dos pioneiros no estudo de tensões desenvolvidas durante a cavitação foi Hammitt (Hammitt, 1966). Este cientista, em um dos seus primeiros trabalhos sobre cavitação se baseou no critério de falha de Tresca (critério da Tensão de Cisalhamento Máxima) para considerar que a tensão cisalhante projetada crítica, desenvolvida em planos de escorregamento formando aproximadamente $45^{\circ} \mathrm{com}$ o eixo de aplicação das tensões e responsável pela falha em materiais dúcteis submetidos à ação de bolhas de cavitação. Como simplificação do modelo foi considerada uma tensão axial de compressão normal à superfície, por ser a que maior semelhança tem com as tensões desenvolvidas numa superfície submetida à cavitação. Até hoje, esse modelo continua sendo utilizado para avaliar a pressão exercida por uma onda de choque ou um micro-jato ao atingir uma superfície. Alguns destes estudos se descrevem na sequência.

Mathias (MATHIAS; POHL, 1991) descreveram as tensões desenvolvidas sobre uma superfície submetida à cavitação como sendo semelhantes, em muitos aspectos, às produzidas pelo escoamento de material durante o processo de jateamento (shot peening) de superfícies com partículas duras. Os resultados desta pesquisa indicaram que as ondas de choque, durante o período de incubação, são a principal causa da deformação plástica do material, onde a tensão de escoamento dos materiais é reduzida pela alta frequência da carga dinâmica.

Vários outros pesquisadores têm realizado medições da pressão produzida na superfície, utilizando como instrumento de aquisição de dados um transdutor piezelétrico colado na superfície submetida à implosão de bolhas de cavitação. Edwards e Jones (EDWARDS; JONES, 1960), conseguiram medir pressões da ordem de $10 \mathrm{GPa}$, quando bolhas de vapor implodiram em cima de um sensor piezoelétrico. Okada (IWAI; OKADA; TANAKA, 1989), obtiveram valores de 
pressão da ordem de $720 \mathrm{GPa}$, em um teste de EC numa liga de alumínio. Valor que supera em quase 1000 vezes o limite de escoamento do alumínio. Momma (MOMMA; LICHTAROWICZ, 1995), utilizando um sistema de transdutor melhorado, obtiveram um valor de pressão próximo de 336 GPa.

Como se percebe, os valores de pressão obtidos são bastante diferentes, embora suficientemente altos para provocar dano em qualquer superfície sólida.

Procurando melhorar as medidas das pressões presentes nas superfícies submetidas a EC, os pesquisadores também têm utilizado simulações, usando as mais variadas expressões matemáticas e recentemente, auxiliados por programas de computador apropriados, cada um com suas próprias simplificações. Uma das primeiras simulações conhecidas foi realizada por Plesset e Chapman (PLESSET; CHAPMAN, 1971), onde foi considerada a implosão de uma única bolha com crescimento assimétrico, porém desprezando as propriedades do líquido como a viscosidade e a compressibilidade, entre outras. Com este modelo foram encontradas velocidades de colapso de até $1500 \mathrm{~m} / \mathrm{s}$ e pressões (chamadas por eles de pressões devidas a golpe de aríete), de até 0,2 GPa.

Como discutido em 2.2.2, Chen e colaboradores (CHEN; LIU, 2009), utilizavam um teste de cavitação vibratória, em um aço de médio carbono, para simular o efeito da implosão de bolhas de cavitação e para explicar o tipo de tensões atuantes numa superfície submetida a EC. Estes pesquisadores se apoiaram em teorias físicas como as apresentadas no trabalho de Miller and Pursey (MILLER; PURSEY, 1955) acerca da propagação e do tipo de ondas que podem percorrer um corpo sólido, quando estas são originadas por cargas impulsivas, como é o caso da EC. A partir destas teorias e de micrografias obtidas na pesquisa através de um microscópio eletrônico de varredura (MEV), Chen e Liu explicaram a forma como o dano é apresentado, tanto na superfície quanto na subsuperfície, de materiais submetidos a EC.

De qualquer forma, o entendimento do problema da EC, visando diminuir seu efeito em peças e equipamentos industriais, pode ser enfrentado através do conhecimento de fenômenos mecânicos e metalúrgicos que atuam durante o processo de desgaste, como por exemplo, entender a reação física (mudança de forma ou de estado metalúrgico) de um material, quando este é submetido a desgaste EC, levando em conta a forma como as tensões e deformações, decorrentes do processo, se desenvolvem nas superfícies impactadas e o seu efeito imediato sobre elas. Na sequência serão tratados aspectos gerais da forma como uma superfície pode ser degradada durante o processo de desgaste EC. 


\subsection{Deformação plástica}

A deformação plástica ocorre quando um material, submetido a algum tipo de tensões, adquire deformações permanentes causadas pela movimentação de discordâncias ou ocorrência de maclação, repercutindo na mudança de orientação cristalográfica e incorporando defeitos cristalinos ao material, como formação e rearranjo de discordâncias (HULL; BACON, 2001).

Em policristais, a diferença de orientação dos grãos gera restrições de movimentação entre eles, fazendo com que a deformação plástica aconteça de forma heterogênea, variando de grão para grão e mesmo dentro de um único grão.

Durante a deformação plástica, a movimentação de discordâncias e a interação entre elas e com outras imperfeições, reduz a sua mobilidade média, tornando o material mais resistente à deformação, sendo necessárias tensões cada vez maiores para provocar uma deformação adicional. Este fenômeno é chamado de encruamento (ou endurecimento por deformação) (PADILHA, 2000).

As mudanças estruturais devidas à deformação plástica, levam a mudanças nas propriedades dos metais deformados, como por exemplo: aumento de dureza, aumento na resistência mecânica, diminuição da permeabilidade magnética, entre outras.

A deformação plástica em um monocristal ocorre quando planos atômicos densamente compactados atingem uma tensão de cisalhamento máxima, fazendo com que se movimentem uns sobre os outros.

Em materiais policristalinos, os planos e direções associados ao escorregamento correspondem ao sistema com a maior tensão de cisalhamento projetada, sendo que os sistemas de escorregamento estão diferentemente orientados de um grão para outro em decorrência de sua orientação cristalográfica. Em geral, o processo de escorregamento iniciado em um grão está confinado àquele grão podendo ser diferenciado daqueles que ocorrem nos grãos vizinhos. Porém é de se esperar que a deformação não seja homogênea, mesmo dentro de um grão isolado, como já foi dito.

Durante a deformação plástica, fenômenos como fragmentação dos grãos, surgimento de bandas de escorregamento e formação de uma subestrutura celular de discordâncias ocorrem comumente nos materiais metálicos. Esses fenômenos são apresentados esquematicamente na figura 2.5. 


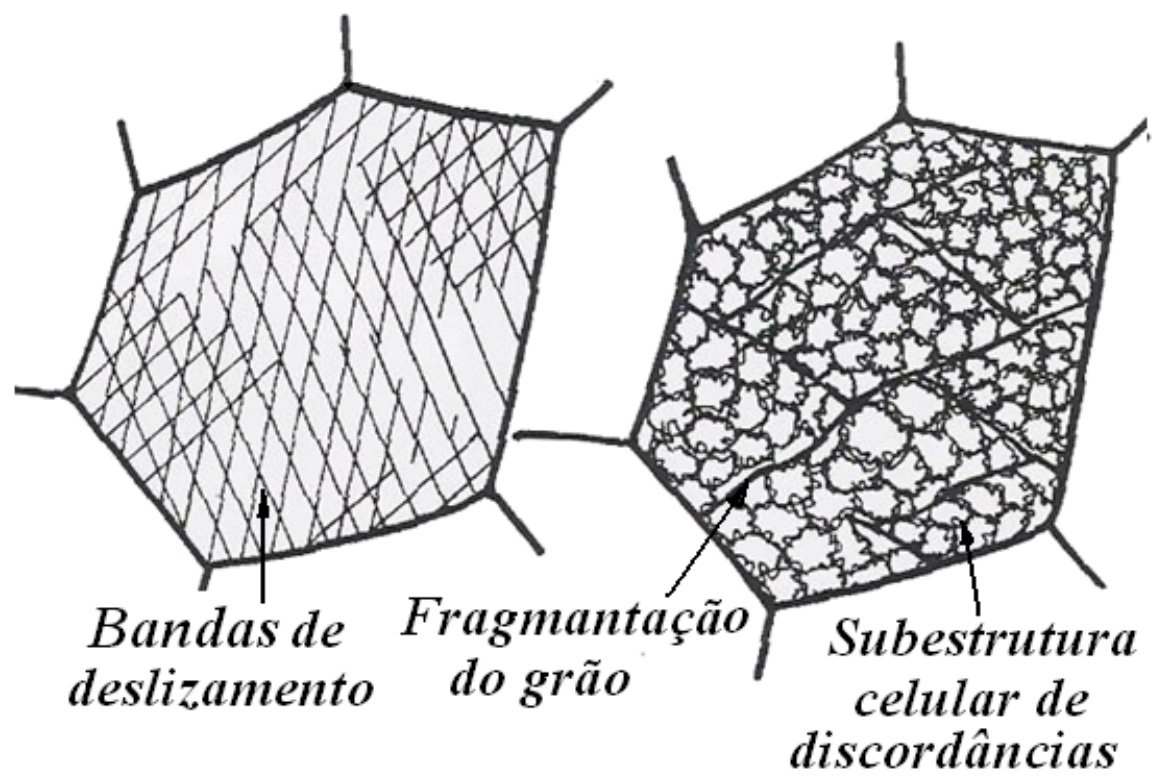

Figura 2.5: Representação esquemática da fragmentação de grãos e formação de bandas de escorregamento e arranjos celulares de discordâncias para baixas deformações (KESTENBACH, 2003).

As bandas de escorregamento, como as mostradas na figura 2.5, indicam que diferentes sistemas de escorregamento foram ativados em diferentes regiões de um determinado grão. Por outro lado, basta pouca deformação plástica para que as subestruturas celulares, conhecidas como CBs (Cell Blocks), aparentemente uniformes, se formem em todas as regiões, caracterizando-se pela ausência de grandes variações em orientação entre as células, devido ao fato de que a subestrutura é formada apenas para diminuir a sua energia armazenada. Porém, devido aos vários sistemas de escorregamento ativados, blocos diferentes sofrem rotações igualmente diferentes durante a deformação. Esta diferença em rotação gera sub-contornos de grão formados por discordâncias, conhecidas como discordâncias geometricamente necessárias (Geometrically Necessary Boundaries "GNBs") que separam os blocos.

\subsubsection{Tensão de cisalhamento crítica projetada para escorregamento}

Quando uma tensão de tração ou compressão pura é aplicada a um material, quer seja um monocristal ou um policristal, não impede que existam componentes de cisalhamento em planos diferentes daqueles paralelos e perpendiculares à direção da tensão, tais componentes são conhecidas como "tensões de cisalhamento". O ângulo onde se atinge a tensão cisalhante máxima corresponde a 45 graus 
com relação ao eixo de aplicação da carga. O plano e a direção cristalográfica, paralela ao plano em que ocorre o escorregamento, constituem um sistema de escorregamento. Nos metais o escorregamento acontece nos planos mais densos e nas direções mais densas. No caso de metais CFC, os sistemas de escorregamento são do tipo $\{111\}\langle 110\rangle$. A figura 2.6 ilustra este mecanismo (CALLISTER, 2006). A magnitude dessas tensões projetadas, no plano e na direção de escorregamento, depende das tensões aplicadas, da orientação cristalográfica do plano considerado e da direção considerada dentro daquele plano. Para determinar a tensão cisalhante crítica responsável pelo escorregamento de planos atômicos pode-se usar os dados geométricos da figura 2.6, em que $\phi$ representa o ângulo entre a normal ao plano de escorregamento e a direção da tensão de tração aplicada $\sigma_{t}$ e $\lambda$ representa o ângulo entre as direções de escorregamento e da tensão aplicada. A tensão de cisalhamento projetada $\tau \prime$, no plano de escorregamento, é dada por:

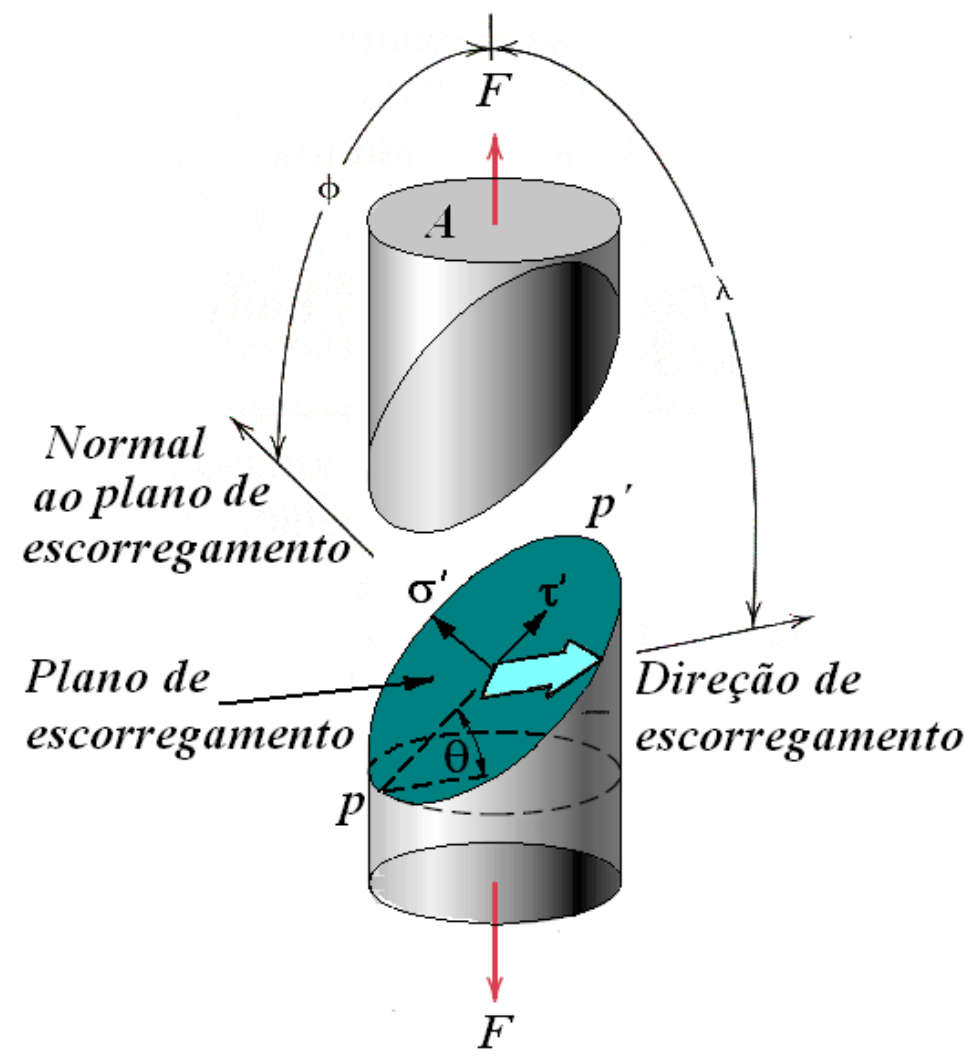

Figura 2.6: Relações geométricas entre o eixo de tração, plano de escorregamento e direção de escorregamento utilizadas para calcular a tensão de cisalhamento projetada para um monocristal. Adaptação (CALLISTER, 2006)

$$
\tau \prime=\sigma_{t} \cdot \cos (\phi) \cdot \cos (\lambda)
$$

No caso de um monocristal metálico, este possui uma quantidade de sistemas de escorregamento diferentes que têm a possibilidade de serem ativados através de 
uma tensão de cisalhamento projetada (no plano e na direção de escorregamento). Essa tensão é diferente para cada sistema, pois a orientação de cada plano, em relação ao eixo de tensão, é também diferente. Porém, sempre haverá um sistema de escorregamento orientado de forma favorável, isto é, que possua a maior tensão de cisalhamento projetada, $\tau \prime$ (máx). Tal tensão, conhecida como tensão de cisalhamento projetada crítica, $\tau_{r c}$; representa a tensão de cisalhamento mínima exigida para iniciar o escorregamento (isto é, para movimentar uma discordância), assim, a tensão de cisalhamento projetada crítica é calculada como:

$$
\tau_{r c}=\sigma_{T} \cos (\phi) \cdot \cos (\lambda)
$$

A equação 2.3 pode ser escrita como:

$$
\tau_{r c}=\frac{F}{A} \cos (\phi) \cdot \cos (\lambda)=\sigma M
$$

onde F é a força de tração aplicada; A a área da seção transversal e $M=$ $\cos (\phi) \cdot \cos (\lambda)$ é conhecido como fator de Schmid.

A tensão de cisalhamento projetada em algum plano particular é simplesmente a tensão aplicada $(\mathrm{F} / \mathrm{A})$ vezes o fator de Schmid (MEYERS; CHAWLA, 2008). Portanto, a tensão de cisalhamento projetada de qualquer sistema de escorregamento é proporcional ao seu fator de Schmid.

Para um valor qualquer de $\phi$, o máximo fator de Schmid ocorre para $\lambda=$ 90- $\phi$. Portanto, o máximo fator de Schmid ocorre no máximo da função $\cos (90-$ $\phi) \cdot \cos \phi$, que é obtido com $\phi=45^{\circ}$. Isto mostra que a tensão de cisalhamento projetada crítica ocorre próxima de um plano a $45^{\circ}$ do eixo de tração e que o maior valor possível do fator de Schmid é 0,5 .

Em conclusão, quando se têm vários sistemas de escorregamento cristalograficamente equivalentes em um monocristal, a lei de Schmid diz que aquele que tiver a maior tensão de cisalhamento projetada se tornará ativo; porém, se dois ou mais sistemas estão igualmente tensionados, haverá escorregamento em todos.

Para o caso de materiais policristalinos, a teoria de deformação de Taylor é ainda hoje bastante aceita (TAYLOR, 1938). Como hipóteses, Taylor assume que deve haver compatibilidade de deformação nos diversos grãos para garantir a coesão intergranular. Portanto, durante a deformação plástica de um material policristalino, todos os grãos do material sofrem a mesma mudança de formato, isto é, os grãos sofrem a mesma deformação que a amostra policristalina (MEYERS; CHAWLA, 2008). 
A diferença de um monocristal, em relação a um policristal, é que o primeiro quando submetido a uma tensão de cisalhamento capaz de movimentar discordâncias em planos atômicos de escorregamento, pode-se deformar livremente, exceto quando houver alguma restrição externa. Esta liberdade não existe para os grãos de um material policristalino, pois eles estão sujeitos a restrições exercidas por cada um dos seus vizinhos, que por sua vez estão se deformando de uma única maneira. Em consequência, como a continuidade deve ser mantida, caso a deformação continue, o processo de deformação será diferente em várias partes de um grão. Assim, um metal policristalino se deforma com o desenvolvimento de orientações que são diferentes de grão para grão e diferentes de região para região dentro de um grão individual.

Para avaliar a sua teoria, Taylor trabalhou com amostras de alumínio (estrutura cristalina CFC com doze sistemas de escorregamento). O problema de Taylor consistia em compreender qual ou quais os sistemas de escorregamento devem operar para permitir a deformação do material. Assim, foi usado o seguinte critério: a combinação de sistemas de escorregamento que fosse capaz de executar certa deformação, com a menor tensão de cisalhamento, seria o sistema de escorregamento dominante que operaria.

Apoiado nos estudos de Von Misses, primeiro pesquisador a notar que no mínimo cinco sistemas de escorregamento independentes são necessários para satisfazer uma determinada deformação incremental imposta a um material policristalino, Taylor considerou que esses cinco sistemas são aqueles que produzem o trabalho interno mínimo $(d w)$ para começar a deslizar, isto é:

$$
d W=\tau_{r c} \sum_{5} \delta \gamma_{i}=\text { minimo }
$$

onde $\delta \gamma_{i}$ é a quantidade de escorregamento no sistema i e $\tau_{r c}$ é a tensão cisalhante crítica.

Fisicamente, realizar o trabalho mínimo quer dizer que o limite de escoamento do material que está sendo deformado é atingido (porém não ultrapassado), em todos os sistemas de escorregamento envolvidos. De igual maneira, em todos estes sistemas, a tensão resolvida de cisalhamento tem igual valor. No seu estudo, Taylor encontrou que a média do fator de Schmid para os cinco sistemas de escorregamento tem um valor de 3,06 para a estrutura CFC. 
Para o caso de um monocristal submetido a uma tensão de tração uniaxial, o trabalho interno mínimo dW é dado por:

$$
d W=\sigma_{x} d \varepsilon_{x}
$$

Onde $\sigma_{x} \cdot d \varepsilon_{x}$ são, respectivamente, a tensão e a deformação de tração aplicadas ao monocristal, o que conduz à definição do Fator $\mathrm{M}$ de Taylor como:

$$
M=\frac{\sigma}{\tau_{c}}=\frac{\sum \delta \gamma}{\delta \varepsilon}
$$

Onde $\sum \delta \gamma$ é a soma dos cisalhamentos nos sistemas de escorregamento cristalograficamente definidos, $\tau_{c}$ é a tensão cisalhamento crítica.

O fator de Taylor FT de um cristal depende da sua orientação cristalográfica e da tensão aplicada para gerar uma determinada deformação. Por exemplo, para um cristal sob carga de tração, assumindo que todos os sistemas de escorregamento têm a mesma tensão de cisalhamento projetada crítica, o fator de Taylor seria portanto a relação da tensão ao longo do eixo de tração com relação à tensão de cisalhamento projetada crítica. Dessa forma o FT é uma medida de quão favorável um cristal está orientado para acomodar a deformação aplicada, sendo que um valor pequeno para o FT indica que o cristal exige um esforço pequeno para se deformar, o que implica que a sua orientação é favorável, e viceversa (SARMA; DAWSON, 1996).

Assim, o FT, que é uma medida do trabalho plástico realizado durante a deformação plástica de cristais, é um parâmetro de interesse particular, já que se tem demonstrado que variações do FT de um grão, com uma determinada orientação, para outro grão com outra orientação cristalográfica totalmente diferente podem ajudar a prever fenômenos de falha em materiais. Por exemplo, Wright (WRIGHT; FIELD, 1998) mostrou que grãos com baixo FT ao lado de grãos com relativamente alto FT, são mais suscetíveis a grandes concentrações de tensões (PRZYBYLA; ADAMS; MILES, 2007). Afinal, tanto o FT quanto o fator de Schmid (FSch) são ambos função da orientação cristalográfica do reticulado no monocristal.

Estudos posteriores aos realizados por Taylor, desenvolvidos por Bishop e Hill (BISHOP; HILL, 1951) ao considerarem uma distribuição uniforme de orientações num material CFC, sob o princípio do trabalho máximo, mostraram que na realidade, ao impor uma dada deformação $d \varepsilon_{i j}$ em um policristal CFC, seis ou oito 
sistemas são ativados simultaneamente em cada cristal (VIANA; PAULA, 2003).

\subsubsection{Modos de falha presentes durante o desgaste por EC}

Em geral, afirma-se que os metais falham pela combinação de cargas de choque e fadiga de baixo ciclo como resultado de tensões geradas durante o colapso de bolhas de cavitação (RICHMAN; MCNAUGHTON, 1990). Neste caso o início do dano, tanto inter quanto intra-granular, depende das propriedades dos contornos de grão e da presença e interação de bandas de escorregamento persistentes, respectivamente, sendo que, as propriedades dos contornos de grão podem afetar as propriedades mecânicas dos materiais policristalinos, entre elas a tenacidade à fractura (BEDKOWSKI et al., 1999; RHO; HONG; NAM, 2000).

A evolução do desgaste durante a cavitação pode ser tipicamente dividida em quatro etapas (ver figura 2.7), em função da atuação de diferentes mecanismos de desgaste. Na primeira delas, conhecida como período de incubação, associase o mecanismo de dano dominado por deformação plástica, em que impactos hidrodinâmicos promovem a formação de linhas de escorregamento (ou bandas de escorregamento persistentes), além da formação de pequenas crateras superficiais (pites). No início do ataque da EC, o material é muito dúctil e apto a absorver uma grande parte da energia de impacto por deformação plástica. O acúmulo de deformações induz a um endurecimento progressivo das camadas superficiais do material, o que diminui sua capacidade de deformação tornando-o mais frágil, tanto que a probabilidade de aparecimento de trincas e microfraturas aumenta. Ao final do período de incubação a densidade de crateras aumenta formando ondulações que chegam a afetar os contornos de grão. Nesta etapa normalmente não se registra perda de massa, porém, isto não significa que as superfícies não tenham sofrido dano e até mesmo que algum material tenha sido arrancado, significa somente que a massa perdida é tão baixa que se encontra abaixo da resolução da balança utilizada para o acompanhamento do desgaste.

No período de aceleração, as trincas formadas na superfície e na sub-superfície se propagam juntando-se umas às outras, levando à formação de cavidades (pites maiores) na superfície, além de desprendimento de partículas de desgaste "debris". Neste período o modo de dano dominante é a fadiga acompanhada de fratura frágil, começando-se a registrar perda de massa (JEAN; JEAN, 2005).

No período de desgaste estável, o dano é generalizado, e os diferentes mecanismos de dano atuam todos de uma vez. Neste período o taxa de desgaste chega a ser constante. 


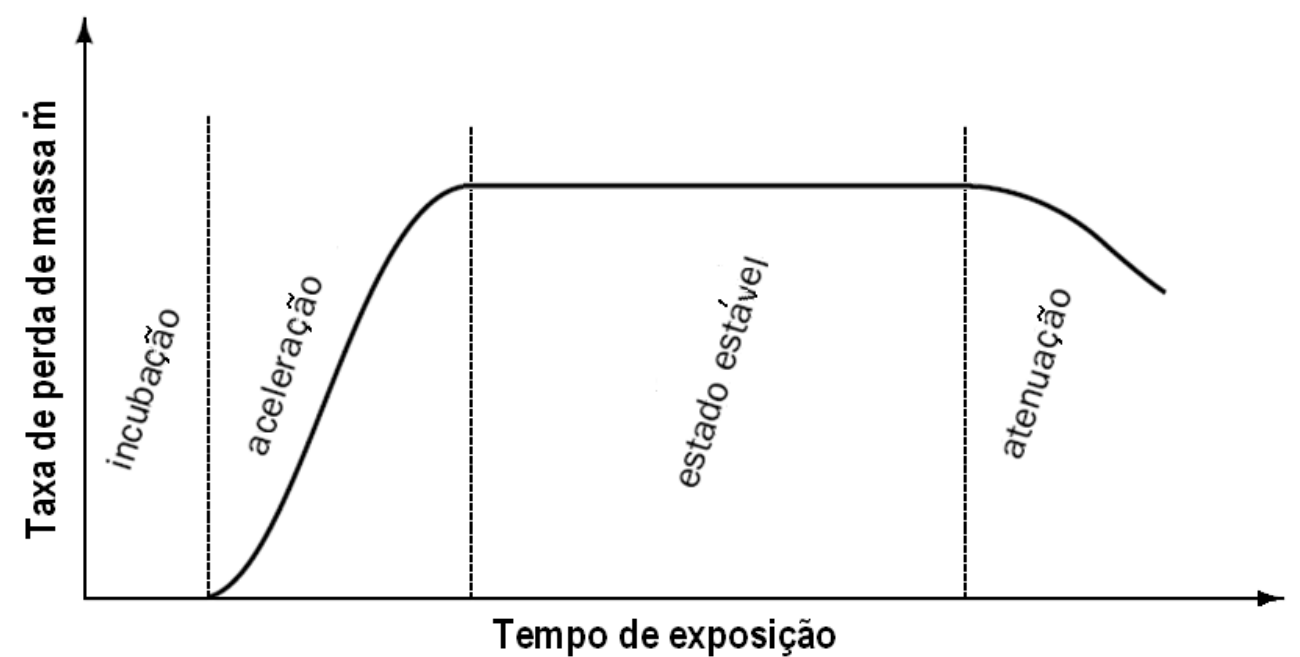

Figura 2.7: Etapas do processo de desgaste por EC (JEAN; JEAN, 2005)

Durante o período de atenuação o material sofre uma queda da taxa de desgaste devido a fenômenos como o endurecimento por deformação e à formação de novas fases mais resistentes, entre outros fenômenos.

\subsubsection{Materiais utilizados em aplicações onde se tem desgaste EC}

Desde o momento que os pesquisadores começaram a estudar o problema do desgaste EC, inúmeros têm sido os materiais e processos testados, visando compreender e minimizar os efeitos deletérios deste fenômeno nas superfícies de trabalho. Um resumo dos materiais testados em relação à resistência ao desgaste por EC pode ser encontrado no trabalho de Hattori e Ishikura (HATTORI; ISHIKURA, 2010).

Nesse sentido, as superligas estão entre os materiais mais utilizados para este propósito, sendo que, uma das subclasses de superligas à base de cobalto é o Stellite-6, material que, em geral, é composto por carbonetos do tipo $M_{7} C_{3}$ e $M_{23} C_{6}$ (onde $\mathrm{M}$ representa principalmente átomos de $\mathrm{W}$ ou $\mathrm{Mo}$ ) dispersos em uma solução sólida rica em cobalto como matriz. A morfologia dos carbonetos no Stellite-6 é bastante dependente da composição química do material e do teor de carbono (HEATHCOCK; BALL; PROTHEROE, 1981). O Stellite6 tem ampla aplicabilidade na produção de peças e recobrimentos utilizados em diversos tipos de turbinas, em que uma alta resistência à corrosão e ao desgaste por EC é requerida. Entretanto, o alto preço destas ligas e a dificuldade da sua usinagem têm motivado a procura por outras ligas mais acessíveis econômica e tecnologicamente. Outros materiais bastante utilizados e que têm 
um comportamento eficiente frente ao desgaste por EC são alguns tipos de aços inoxidáveis como os dúplex (MESA; GARZÓN; TSCHIPTSCHIN, 2009a), austeníticos (GLAVATSKAYA; SOZINOV; PETROV, 1999)e martensíticos (LO; CHENG; MAN, 2003), porém modificados por algum tratamento térmico ou termo-químico.

Em relação aos processos utilizados para aumentar a resistência ao desgaste EC de materiais, os recobrimentos duros têm sido bastante usados (BREGLIOZZI et al., 2005; KRELLA; CZYZNIEWSKI, 2008a, 2008b), além de processos nos quais o endurecimento por deformação superficial é provocado por impacto com jato de partículas duras ( "sand blasting", por exemplo), ou inclusive submeter ao mesmo efeito da EC peças mecânicas (como engrenagens), a partir de um processo conhecido como cavitation shotless peening (CSP). (SOYAMA; MACODIYO, 2005; SOYAMA et al., 2003).

Nos últimos anos, recobrimentos com filmes finos do tipo carbonetos e nitretos de titânio, boro e outros elementos de liga e combinações destes, depositados sob as mais diversas técnicas, têm sido utilizados visando formar camadas resistentes à EC com excelentes resultados (FACTOR; ROMAN, 2002a, 2002b; KLAPKIV; POVSTYANA; NYKYFORCHYN, 2006; KRELLA; CZYZNIEWSKI, 2008b).

Como mostrado acima, são várias as possibilidades de que aços inoxidáveis sejam utilizados na fabricação de peças e equipamentos submetidos ao desgaste por EC. Da mesma forma, os mais diversos processos e tratamentos térmicos, termo-químicos e termomecânicos têm sido utilizados com o objetivo de aumentar a resistência ao desgaste destes materiais.

Dentre os tratamentos termoquímicos que têm fornecido importantes resultados frente ao desgaste por EC, quando realizado nos aços inoxidáveis austeníticos, martensíticos e dúplex (GARZÓN, 2004; GARZÓN et al., 2005; MESA; GARZÓN; TSCHIPTSCHIN, 2009b), estão a nitretação gasosa em alta temperatura e a nitretação por plasma. Na sequência é realizada uma breve apresentação destes tipos de materiais e dos tratamentos termoquímicos acima mencionados.

\subsection{Aços inoxidáveis}

Trata- se de uma família de aços com características muito especiais, tais quais: alta resistência a alguns tipos de corrosão e desgaste, acompanhada de alta ductilidade e moderada resistência mecânica e tenacidade, além de serem completamente recicláveis e de excelente comportamento mecânico em alta temperatura. Estas características são alcançadas graças ao seu conteúdo 
de elementos de liga, principalmente $\mathrm{Cr}$ (> 10,5\%), Ni, e outros elementos em menor proporção como Mo, Ti, V, N, Mn, Si, etc. A excelente resistência à corrosão dos aços inoxidáveis deve-se à capacidade que estes materiais têm

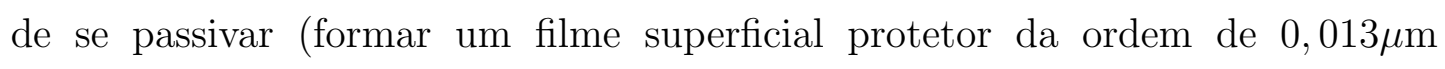
de espessura, em ambientes corrosivos. Este filme tem a capacidade de se reconstruir ao ser danificado, mantendo uma proteção permanente do material. Estas características interessantes dos aços inoxidáveis têm sido responsáveis pelo uso destes materiais nos mais diversos campos da engenharia, abrangendo desde produtos da vida cotidiana até peças mecânicas de grande responsabilidade em indústrias complexas como a química, petroquímica, aeronáutica, nuclear entre outras.

Embora haja mais de 60 tipos de aços inoxidáveis comerciais, estes podem ser agrupados em cinco famílias, sendo estas: ferríticos, austeníticos, martensíticos, endurecíveis por precipitação e dúplex (de estrutura austenita + ferrita). Por serem o $\mathrm{Cr}$ e o $\mathrm{Ni}$ os principais elementos de liga destes aços, tem-se uma classificação das diferentes fases em função da variação do teor equivalente destes dois elementos, como mostrado no diagrama da figura 2.8, conhecido como diagrama de Schaeffler.

$$
\begin{array}{r}
\text { Crequivalente }=(C r)+2(S i)+1.5(M o)+5(V)+5.5(A l)+1.5(T i)+0.75(W) \\
\text { Niequivalente }=(N i)+(C o)+0.5(M n)+0.3(C u)+25(N)+30(C)
\end{array}
$$

A seguir serão apresentados de forma breve as famílias de aços inoxidáveis dúplex e austeníticos, por serem as famílias envolvidas neste trabalho, além dos aços inoxidáveis com alto teor de nitrogênio.

\subsubsection{Aços inoxidáveis dúplex}

Possuem uma estrutura mista de ferrita e austenita, a qual é obtida com o correto balanço entre os elementos de liga formadores da fase alfa (ferrita) como Mo, Ti, $\mathrm{Nb}, \mathrm{Si}, \mathrm{Al}$ e os elementos de liga formadores da fase gama (austenita), como Ni, Mn, C e N, sendo que o conteúdo de Cr deve estar próximo de $20 \%$ em massa, podendo variar entre $18 \%$ e $28 \%$ em massa. Já a proporção exata das duas fases é determinada por tratamento térmico (BHADESHIA; HONEYCOMBE, 2006).

Os aços inoxidáveis dúplex apresentam valores de limite de resistência, limite 


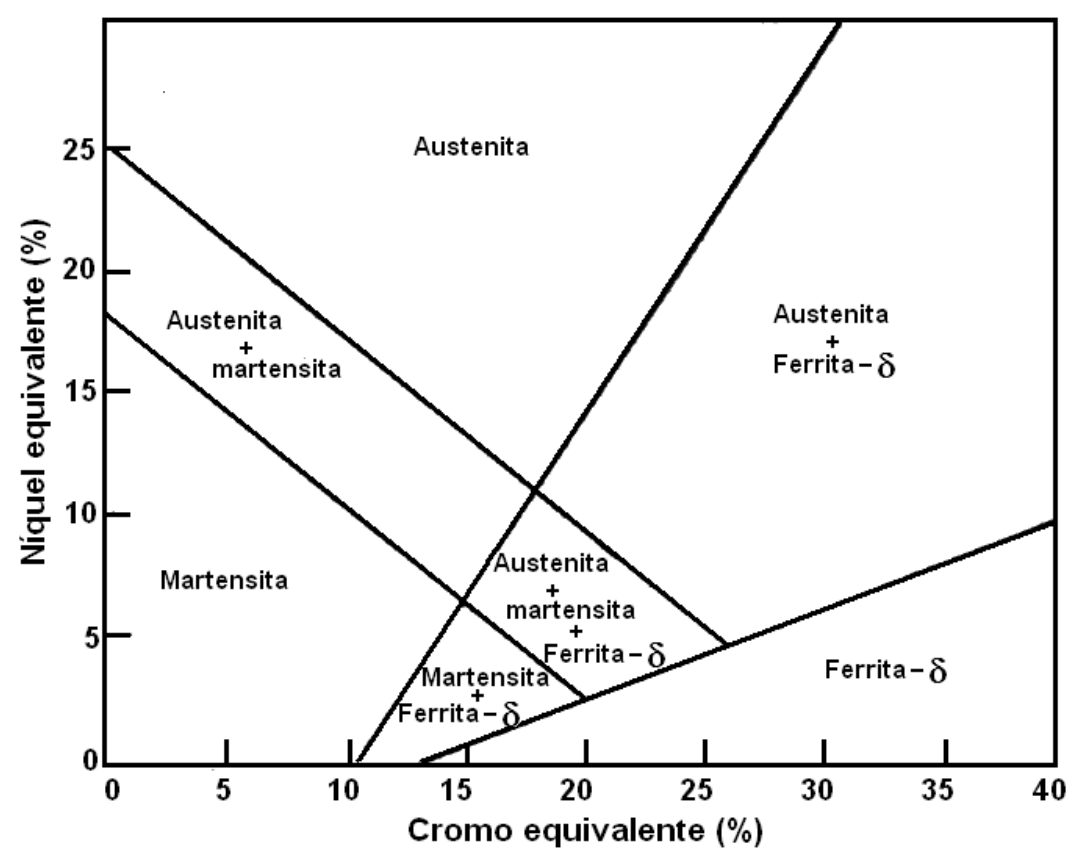

Figura 2.8: Diagrama de Schaeffler. Efeito dos elementos de liga sobre a estrutura básica de aços inoxidáveis Cr-Ni (BHADESHIA; HONEYCOMBE, 2006)

de escoamento e resistência à corrosão sob tensão, maiores do que aços inoxidáveis austeníticos de composição semelhante. Isto se deve ao fato de que a estrutura dúplex apresenta normalmente um tamanho de grão refinado. Por outro lado, se é realizado nestes aços um tratamento termo-mecânico entre $900{ }^{\circ} \mathrm{C}$ e 1000 ${ }^{\circ} \mathrm{C}$, eles podem apresentar superplasticidade, ou seja, alta ductilidade a altas temperaturas.

Suas aplicações principais se encontram em diferentes campos nas indústrias petroquímica (em unidades de dessalinização, dessulfuração e equipamentos para destilação) e papel e celulose (em digestores, plantas de sulfito e sulfato e sistemas de branqueamento). Sua temperatura de trabalho deve estar entre $-50{ }^{\circ} \mathrm{C}$ e 300 ${ }^{\circ} \mathrm{C}$, do contrário a queda de tenacidade poder ser um grande problema (UYN; HUDD, 2000).

O aço inoxidável dúplex mais conhecido é o UNS S31803, que possui ampla utilização nas indústrias químicas, de óleo, gás, papel e celulose, aplicado principalmente em evaporadores, dutos e tanques de condução e armazenamento de material corrosivo. Quanto às propriedades mecânicas, esse material ocupa um lugar de destaque, pois possui um limite de resistência à tração de $770 \mathrm{MPa}$, limite de escoamento próximo de $515 \mathrm{MPa}$ [4] e alongamento em $50 \mathrm{~mm}$ de $32 \%$. Diversos autores mencionam a possibilidade de soldagem no aço UNS S31803 sem prejuízo das propriedades mecânicas e de resistência à corrosão (DAVIS, 1994). 


\subsubsection{Aços inoxidáveis austeníticos}

São materiais não magnéticos com estrutura cúbica de faces centradas, em que os elementos de liga mais importantes são o cromo e o níquel. A composição típica dos aços pertencentes a esta família varia entre: $16 \%$ a $19 \%$ de Cr; $6 \%$ a $22 \%$ de $\mathrm{Ni} ; 0,03 \%$ a $0,25 \%$ de $\mathrm{C} ; 2 \%$ de $\mathrm{Mn}$, podendo conter outros elementos como Ti, Nb, Ta, etc (KRAUSS, 2005). Além desses elementos, acréscimos de Mo promovem uma melhora da resistência à corrosão localizada. Essas ligas não são endurecidas por tratamento térmico, mas sim por deformação (encruamento), porém, possuem baixo limite de escoamento. No entanto, em algumas circunstâncias, por exemplo, após a deformação, ou se o teor de carbono é muito baixo, estes aços podem transformar parcialmente em martensita em temperatura ambiente. Suas principais aplicações abrangem as indústrias farmacêutica, alimentícia, química, petroquímica, aeronáutica, nuclear, artística, arquitetônica, entre outras (BHADESHIA; HONEYCOMBE, 2006; DAVIS, 1994).

Os aços inoxidáveis austeníticos têm evoluído em torno de princípios da metalurgia física como: variação da estabilidade da austenita em relação à formação de martensita durante o trabalho a frio dos tipos (AISI 301, 302 e 304); redução da porcentagem de carbono e elementos de liga para eliminar a formação de carbonetos de cromo e reduzir a corrosão inter-granular nos tipos (AISI 304L, 316L, 321 e 347); adicionar molibdênio para aumentar a resistência à corrosão por pite no tipo (AISI 316), e adicionar quantidades altas de cromo e níquel para aumentar a resistência a altas temperaturas e a resistência à oxidação nos tipos (AISI 309 e 310). Os aços inoxidáveis austeníticos são propensos à corrosão sob tensão, especialmente na presença de íons cloreto, onde umas poucas ppm destes íons pode ser desastroso. A corrosão sob tensão é um tipo de falha que ocorre em alguns ambientes corrosivos ainda em sob baixas tensões, seja delibera ou diretamente aplicadas, como resultado de tensões residuais no material fabricado (BHADESHIA; HONEYCOMBE, 2006; UYN; HUDD, 2000).

Os aços inoxidáveis austeníticos comuns não são materiais muito resistentes. Tipicamente seu limite de escoamento 0,2\% é aproximadamente de $250 \mathrm{MPa}$ e a sua resistência à tração está entre 500 e $600 \mathrm{MPa}$, mostrando que estes aços têm uma capacidade substancial para encruar. No entanto, os aços austeníticos possuem ductilidade muito alta, com alongamento de cerca de $50 \%$ medido em ensaios de tração (BHADESHIA; HONEYCOMBE, 2006). 


\subsubsection{Aços inoxidáveis com alto teor de nitrogênio (HNS)}

Segundo Spidel (SPIDEL, 1989), um aço inoxidável é considerado de alto N quando o seu teor está acima de um determinado valor, assim: em aços inoxidáveis ferríticos, martensíticos e dúplex, esse teor deve ser maior do que 0,08 \% em massa e para aços austeníticos, o teor deve ser superior a 0,4 \% em massa. Para Gavriljuk e Berns (GAVRILJUK; BERNS, 1999), um aço inoxidável de alto N é aquele que apresenta um teor ao redor de 0,1 \% em massa, caso o aço seja usado em condições de fluência. Para aços austeníticos, este teor deve ser pelo menos de 0,9\% em massa. Outros pesquisadores afirmam que um aço pode ser considerado de alto $\mathrm{N}$ quando o teor atinge o limite máximo de solubilidade deste elemento a $1600{ }^{\circ} \mathrm{C}$ ou na temperatura solidus (FEICHTINGER; ZHEN, 1990).

Existem várias rotas através das quais o nitrogênio pode ser introduzido nos aços inoxidáveis, quer seja fazendo parte de camadas nitretadas na forma de nitretos ou intersticial formando uma solução sólida. A adição de nitrogênio em ligas Fe-Cr pode ser realizada através de fusão convencional, fusão sob altas pressões, metalurgia do pó, nitretação gasosa em alta temperatura e nitretação por plasma. Informações detalhadas sobre estas rotas podem ser encontradas na literatura (RAWERS et al., 1992; RAWERS; MAURICE, 1995; HOROVITZ et al., 1996; SIMMONS, 1996; GAVRILJUK; BERNS, 1999; TORO, 2001).

Dependendo da temperatura utilizada, é comum classificar o tratamento de nitretação em baixa ou em alta temperatura. A nitretação em baixa temperatura é realizada basicamente em atmosfera de amônia, nas temperaturas entre $500{ }^{\circ} \mathrm{C}$ e $575^{\circ} \mathrm{C}$, desta forma, o nitrogênio é difundido na ferrita, obtendo-se uma camada de nitretos do tipo $\gamma \prime\left(\mathrm{Fe}_{4} \mathrm{~N}\right)$ e epsilon $\left(\mathrm{Fe}_{2}-{ }_{3} \mathrm{~N}\right)$, a qual é chamada de camada branca. Esta camada confere ao material nitretado uma elevada resistência ao desgaste, principalmente à abrasão; no entanto, a formação desta camada pode ser inibida com a adição de elementos que reduzem o potencial de nitrogênio na atmosfera (ASM-HANDBOOK-VOL:2, 1991).

Com relação à nitretação gasosa em alta temperatura, este processo tem sido bastante utilizado na última década para melhorar a resistência de aços inoxidáveis a diferentes tipos de desgaste como erosão seca, erosão em meio lamacento, deslizamento e erosão por EC. Da mesma forma, tem-se usado este tratamento para aumentar a resistência mecânica, a bio-compatibilidade e a resistência a vários tipos de corrosão, tais quais: a corrosão sob tensão, generalizada e intergranular. (MESA et al., 2003; TORO; MISIOLEK; TSCHIPTSCHIN, 2003; GARZÓN; TSCHIPTSCHIN, 2004; GARZÓN et al., 2005; OSSA; TSCHIPTSCHIN; 
ROGERO, 2006; RECCO et al., 2007; MESA; GARZÓN; TSCHIPTSCHIN, 2009b). Em relação ao desgaste EC, os aços inoxidáveis austeníticos, martensíticos e dúplex, têm sido os mais amplamente utilizados.

Por ser o tratamento de nitretação gasosa em alta temperatura o procedimento utilizado neste trabalho, será realizada na sequência uma descrição detalhada deste tipo de tratamento.

\subsection{Tratamento termoquímico de nitretação}

\subsubsection{Nitretação gasosa de aços inoxidáveis em alta temperatura}

O tratamento termoquímico de nitretação gasosa em alta temperatura visa a formação de camadas sobre aços inoxidáveis, com diferentes teores de $\mathrm{N}$, em que este elemento fique dissolvido da rede cristalina localizado nos sítios intersticiais, isto é, na forma de solução sólida, e preferivelmente sem presença de precipitados (nitretos). Embora sob certas condições de tratamento, tais nitretos podem aparecer. Portanto o teor de N, a sua localização final no aço e a espessura da camada é função dos parâmetros de tratamento utilizados (pressão, tempo e temperatura). O tratamento é feito em peças maciças sob atmosfera rica em $N_{2}$, em temperaturas que podem variar entre 1000 e $1300{ }^{\circ} \mathrm{C}$, obtendo-se camadas até de $2 \mathrm{~mm}$ de espessura, para tempos de tratamento entre 10 a 12 horas e temperaturas de $1200{ }^{\circ} \mathrm{C}$ a $1300{ }^{\circ} \mathrm{C}$ (GAVRILJUK; BERNS, 1999; GARZÓN, 2004).

Para as ligas Fe-Cr-C, Fe-Cr-N e Fe-Cr-C-N, tanto os átomos de carbono quanto os de nitrogênio podem ocupar os sítios intersticiais octaédricos no reticulado cristalino. Na Figura 2.9 são apresentados os raios máximos de esferas que podem ser introduzidas nos espaços octaédricos e tetraédricos, sem distorção do reticulado cristalino, para o ferro cúbico de faces centradas (CFC) e para o cúbico de corpo centrado (CCC). Para o ferro CFC, os átomos intersticiais ocupam preferencialmente os espaços octaédricos, uma vez que esses espaços são maiores que os tetraédricos. Para o ferro CCC, os átomos intersticiais ocupam, também, os espaços octaédricos, mesmo que para essa estrutura cristalina estes sejam menores que os tetraédricos. Isso porque a tensão gerada por um átomo intersticial nos espaços octaédricos da estrutura CCC pode ser aliviada pelo deslocamento dos dois átomos mais próximos, enquanto o deslocamento para um átomo intersticial nos espaços tetraédricos envolveria quatro átomos em direções que podem causar significativas superposições das nuvens eletrônicas (ROTHERY, 
1968).

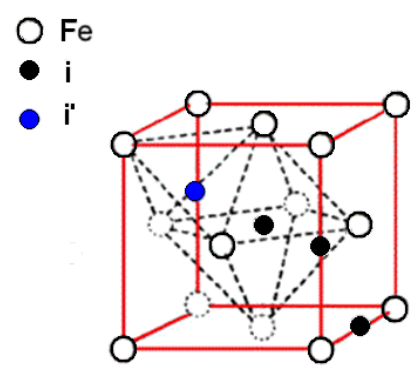

(a)

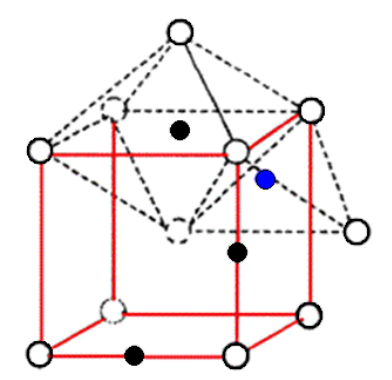

(b)

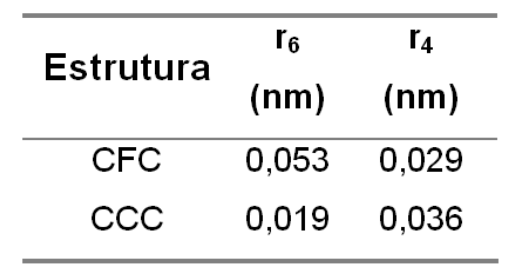

(c)

Figura 2.9: Sítios intersticiais octaédricos - (i) e tetraédricos (il): (a) na estrutura CFC, (b) na estrutura CCC, (c) tamanho, em nm, dos espaços octaédricos $\left(r_{6}\right)$ e tetraédricos $\left(r_{4}\right)$ no ferro (GAVRILJUK; BERNS, 1999)

Embora o raio atômico do carbono seja maior que o do nitrogênio, $r_{c}>r_{N}$, a distorção do reticulado cristalino decorrente da adição de nitrogênio em solução sólida é maior que a provocada pela adição de carbono (GAVRILJUK; BERNS, 1999), conforme mostrado na tabela 2.1.

Tabela 2.1: Variação percentual do parâmetro de rede do ferro CFC gerada pela adição de $\mathrm{N}$ e C; $100 \times(\Delta a \div a o) x \%$-atômica (GAVRILJUK; BERNS, 1999)

\begin{tabular}{ccc}
\hline Liga & Nitrogênio & Carbono \\
\hline Fe & 0,224 & 0,210 \\
\hline Fe-18Cr-10Ni & 0,240 & 0,218 \\
\hline Fe-25Cr-18Ni & 0,214 & - \\
\hline Fe-25Cr-28Ni-2Mo & 0,211 & - \\
\hline
\end{tabular}

Em relação à pressão do gás utilizada na nitretação, seja em baixa ou alta temperatura, é possível fazer a sua escolha de acordo com a porcentagem de nitrogênio que se pretende introduzir. Para isso, pode-se utilizar a lei de Sieverts (GARZÓN, 2004), relação que permite estimar o teor de $\mathrm{N}$ em equilíbrio na interface metal-gás, para uma temperatura determinada, em função da pressão de $\mathrm{N}$ na atmosfera $\left(P_{N_{2}}\right)$. A expressão da lei de Sievert's é dada por:

$$
\% N=K \sqrt{P_{N_{2}}}
$$

onde $\mathrm{K}$ é uma constante que depende da composição química do material e da temperatura.

Por ser um átomo pequeno (intersticial), o N poderia se localizar tanto nos sítios octaédricos quanto nos tetraédricos do reticulado cristalino (GAVRILJUK; SHIVANYUK; SHANINA, 2005). Entretanto, os átomos intersticiais ocupam 
preferencialmente os espaços octaédricos, uma vez que esses espaços são maiores que os tetraédricos.

A melhora de propriedades que o nitrogênio proporciona aos aços inoxidáveis deve-se principalmente à forma como este elemento influencia da estrutura em nível atômico, isto é, a forma de se localizar dentro da rede cristalina e a sua interação com os átomos do material, especialmente com o C e o Cr, além da sua interação com defeitos como lacunas, discordâncias e maclas.

Quando o $\mathrm{N}$ substitui total ou parcialmente átomos de $\mathrm{C}$ num reticulado cristalino, principalmente em aços inoxidáveis austeníticos ou martensíticos, é promovido um ordenamento de curto alcance tanto dos átomos intersticiais quanto dos substitucionais, isto é, há uma tendência dos átomos de $\mathrm{N}$ de ficarem distribuídos homogeneamente no reticulado todo, em quanto que os átomos de $\mathrm{C}$ preferem formar ligações C-C em posições vizinhas do reticulado, dando origem a "clusters" de carbono. Esses "clusters" podem-se localizar tanto nos contornos, quanto no interior dos grãos, fazendo com que a resistência à corrosão localizada e intergranular diminua (GAVRILJUK; BERNS, 1999; GAVRILJUK; SHANINA; BERNS, 2008).

A presença de $\mathrm{N}$ no reticulado cristalino de aços inoxidáveis gera um aumento na concentração de elétrons livres, o que favorece um aumento no caráter metálico das ligações atômicas, e, como consequência, tem-se um aumento da plasticidade do material e da relação limite de escoamento/tenacidade (GAVRILJUK; SHANINA; BERNS, 2008).

Outro efeito do ordenamento de curto alcance dos átomos de $\mathrm{N}$, quando este é adicionado aos aços inoxidáveis, é o favorecimento de uma distribuição planar de discordâncias, fazendo com que o escorregamento no primeiro plano de escorregamento ativado seja a primeira manifestação de deformação plástica, porém o escorregamento em múltiplos planos é reduzido. A consequência deste fato é um aumento na resistência à fluência e à fadiga do material, mas por outro lado, se o aço apresenta um alto teor de N, tem-se uma redução na tenacidade do material. Por outro lado, pesquisas têm mostrado que existe um teor limite de $\mathrm{N}$, acima do qual o efeito benéfico sobre a ductilidade e tenacidade tende a diminuir (GAVRILJUK; BERNS, 1999).

Outras vantagens do $\mathrm{N}$ em aços austeníticos é o aumento da resistência aos tratamentos de sensitização além de deslocar os diagramas TTT (temperatura, tempo, transformação) para a direita, diminuindo a possibilidade do aço sofrer corrosão intergranular. Também foi mostrado (PRESSER; SILCOCK, 1983; 
BREGLIOZZI et al., 2005) que o N atrasa a precipitação de carbonetos e fases intermetálicas, enquanto que, ao mesmo tempo, nitretos de cromo precipitam mais lentamente em comparação aos carbonetos.

\subsubsection{Nitretação por plasma}

Este é outro processo que vem sendo muito utilizado nas últimas décadas para melhorar a resistência ao desgaste e à corrosão de diversos materiais, entre eles os aços inoxidáveis. Esta melhoria ocorre pela formação de camadas duras na superfície do material. No que diz respeito a camadas nitretadas, o N pode ficar dentro do aço, tanto na forma de precipitados como em solução sólida através deste processo.

O processo consiste em submeter um material, o qual é colocado dentro de uma câmara em alto vácuo, a um plasma constituído por um gás parcialmente ionizado contendo íons e elétrons em equilíbrio dinâmico. Com a aplicação de um campo elétrico negativo nas peças a serem tratadas, os íons são acelerados na direção do material. Após a implantação, os íons neutralizam-se e penetram por difusão térmica no corpo do material.

A nitretação por plasma tem algumas vantagens em relação aos processos tradicionais, sendo elas: controle da espessura e do tipo da camada ou camadas que se desejam formar, temperatura de tratamento mais baixa (entre $320{ }^{\circ} \mathrm{C}$ a $450{ }^{\circ} \mathrm{C}$ ), tempo de tratamento inferior para a mesma espessura de camada, uniformidade da espessura da camada, nitretação de peças de formas complexas e maior economia decorrente do menor consumo de gás e energia elétrica (RECCO, 2008).

Em uma das variações da nitretação por plasma, na qual a precipitação de nitretos é suprimida, permite-se a obtenção de uma camada metaestável com o N em solução sólida, denominada austenita expandida. Esta fase, bastante conhecida em aços convencionais austeníticos, apresenta estrutura cúbica de face centrada (CFC) supersaturada em nitrogênio, em que o reticulado CFC da austenita é expandido com relação ao seu estado original, em decorrência da introdução de intersticiais de N em grandes quantidades (10 \% a 40 \% atômico), daí o seu nome (GONTIJO et al., 2005). A deformação do reticulado introduz elevadas tensões residuais de compressão associadas a falhas de empilhamento que promovem o endurecimento superficial sem perda das propriedades de corrosão, capaz de combinar elevada dureza e resistência à corrosão, podendo atingir valores próximos de $1700 \mathrm{HV}$ (HEAT-TECH, 2007). 


\subsubsection{Resistência ao desgaste erosivo por EC de aços HNS}

Um dos primeiros trabalhos envolvendo a avaliação da resistência à EC de aços inoxidáveis austeníticos de alto teor de nitrogênio foi conduzido por Berns e Siebert (BERNS; SIEBERT, 1996). Neste trabalho foi encontrada uma melhora substancial na resistência ao desgaste EC dos materiais nitretados, com nitrogênio em solução sólida, em que as tensões pulsantes, provenientes do impacto após o colapso de bolhas de cavitação, são consideradas como a principal causa do dano superficial. Essas tensões provocam deformação plástica, manifestada no aparecimento de uma superfície rugosa contendo maclas e bandas de escorregamento, que por sua vez são fontes de formação de micro-trincas devido ao efeito de entalhe. A deformação da superfície conduz a um incremento na densidade de discordâncias, provocando endurecimento por deformação, pelo fato de que são necessárias maiores tensões para começar a danificar o material. Este processo todo leva o material a sofrer fadiga, provocando danos severos na superfície do material que falha finalmente por fratura.

Em trabalhos mais recentes tem sido investigada a resistência ao desgaste por EC de aços inoxidáveis austeníticos de alto teor de nitrogênio, porém levando em conta a mais ampla variedade de parâmetros, tanto do ensaio quanto metalúrgicos, que podem influenciar o comportamento destes materiais frente a esse tipo de desgaste. Parâmetros tais como variações no tamanho de grão e do pH da solução. Neste caso, encontrou-se que, à medida que diminui o tamanho de grão aumenta a resistência à EC, por causa da maior quantidade de superfície, representada pelos contornos de grão, os quais têm uma maior ação de sustentação contra as tensões exercidas durante a EC. De igual maneira, no caso de realizar algum tratamento para refinar o tamanho de grão de um material, o efeito benéfico desse refino de grão sobre a resistência à EC pode ser atribuído ao endurecimento por refino de grão, que leva ao aumento da resistência à deformação plástica e à diminuição da intensidade do micro-relevo gerado na superfície devido. (GAVRILJUK; BERNS, 1999; GARZÓN et al., 2005; MESA; GARZÓN; TSCHIPTSCHIN, 2008). No caso da variação do pH, foi encontrado que quanto menor é o valor deste parâmetro, menor é também a resistência à EC. Isto deve-se ao fato que tanto a EC, quanto a corrosão eletroquímica têm a sua atividade aumentada(BREGLIOZZI et al., 2005).

Qiao et al (QIAO et al., 2007), compararam a resistência ao desgaste por EC de um aço HNS (0,66\% de $\mathrm{N}$ em massa) com um aço CrMnN (0,30 \% de $\mathrm{N}$ em massa), encontrando que o aço HNS apresentava uma maior resistência, a qual foi 
atribuída a facilidade que este aço tem de sofrer endurecimento por deformação, a baixa energia de falha de empilhamento e efeitos benéficos de rearranjo de discordâncias e sistemas de escorregamento, que não facilitam a propagação de trincas, mesmo elas estando presentes.

\subsection{Difração de Elétrons Retroespalhados (EBSD)}

A difração de elétrons retroespalhados (EBSD), também conhecida como Electron Backscattering Patterns (EBSP), Electron Backscattering Kikuchi Patterns (BEKP) ou Wide Angle Kikuchi Patterns (WEKP), é uma técnica relativamente recente utilizada para estudar aspectos relacionados com a cristalografia de materiais monocristalinos ou policristalinos tais como textura cristalográfica (orientação preferencial dos cristais) e ocorrência de eventos como oxidação, fratura, precipitação, recristalização, mobilidade de contornos de grão, difusão, entre outros; além de informar sobre o tamanho de grão, tipo e número de fases (incluindo partículas de precipitados), desorientação entre dois ou mais grãos, etc., com resolução de até $50 \mathrm{~nm}$ (RANDLE; ENGLER, 2000). Na realidade, os elétrons retroespalhados já eram conhecidos e utilizados como informação na área de caracterização de materiais há muitos anos, porém foi o pesquisador Dingley (DINGLEY; RANDLE, 1992) quem foi o primeiro a usar uma câmera de TV sensível a luminosidade para adquirir os padrões de difração usando um microscópio eletrônico de varredura, estimulando com isto o desenvolvimento de sistemas comerciais a partir dos quais se abriram novas possibilidades de pesquisa no campo da cristalografia.

O sistema EBSD, capaz de detectar e analisar os elétrons retroespalhados pode ser adaptado ao microscópio eletrônico de varredura (MEV), que fornece o feixe de elétrons necessário que, ao incidirem sobre a amostra geram os elétrons retroespalhados. Esta adaptação permite combinar a técnica EBSD com imagens de elétrons secundários (SE), elétrons retroespalhados (BSE) e micro-análise EDS (Energy Dispersive X-ray Spectroscopy) e WDS (Wavelength dispersive X-ray spectroscopy ) para melhorar as análises realizadas nos materiais. A inovação mais recente tem sido o uso do EBSD em conjunto com a microscopia de alta resolução Field Emission Gun Scanning Electron Microscopy (FEGSEM) e consequente aumento na resolução espacial tem estendido a faixa de aplicação do EBSD (HUMPRHEYS; HATHERLY, 1996; SCHWARTZ; KUMAR; ADAMS, 2000).

Uma importância particular no crescimento do EBSD como técnica metalográfica é o desenvolvimento automatizado de padrões de análise muito 
rápidos, em que sistemas modernos conseguem realizar milhares de medidas de orientação em questão de minutos (SCHWARTZ; KUMAR; ADAMS, 2000).

O uso da técnica EBSD requer que a amostra seja colocada dentro da câmara do MEV ou MET, previamente preparada, inclinada de forma que o ângulo de incidência do feixe de elétrons seja próximo de 70 a $75^{\circ}$, de modo a encurtar o percurso dos elétrons retroespalhados e diminuir a fração de elétrons absorvidos pela própria amostra (RANDLE; ENGLER, 2000). A figura 2.10 mostra o princípio de funcionamento de um sistema EBSD acoplado a um MEV e a formação dos padrões de Kikuchi.

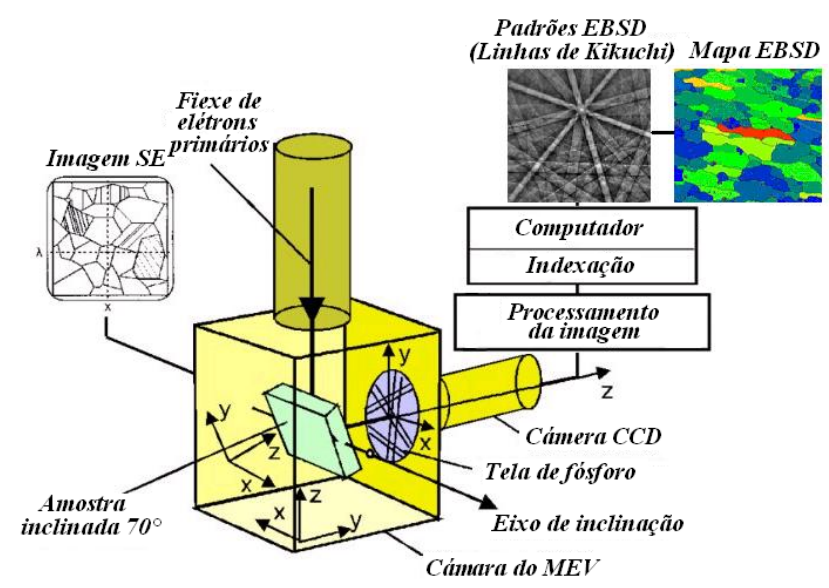

(a)

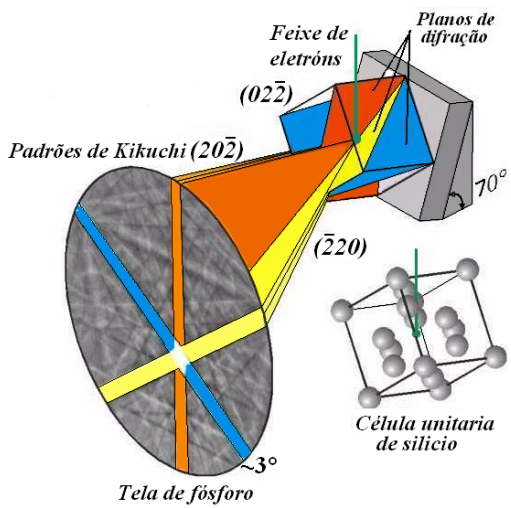

(b)

Figura 2.10: Principio de funcionamento do EBSD e posicionamento da amostra (a) e principio de formação de padrões de Kikuchi (b)(LEIBNIZ-INSTITUTE, 2007).

Os elétrons difratados da superfície incidem em uma tela de fósforo posicionada próxima a amostra, formando a imagem de difração composta por linhas de Kikuchi (ver figura 2.10 (b)). Essas linhas são formadas quando elétrons retroespalhados sofrem difração em planos atômicos favorecidos pela lei de Bragg, formando dois cones de difração, como mostrado na figura 2.11. Cada banda ou par de linhas representa um plano cristalográfico particular. A imagem da tela de fósforo é captada por uma câmera de vídeo de alta sensibilidade e levadas a um computador onde um software especial as analisa e indexa.

Uma vez finalizada a varredura em uma determinada amostra, passa-se a usar o software que acompanha o sistema EBSD para determinar as características cristalográficas de interesse do material em estudo, como a textura, tamanho de grão, tipo de contornos de grão, tipo de fases, etc. 


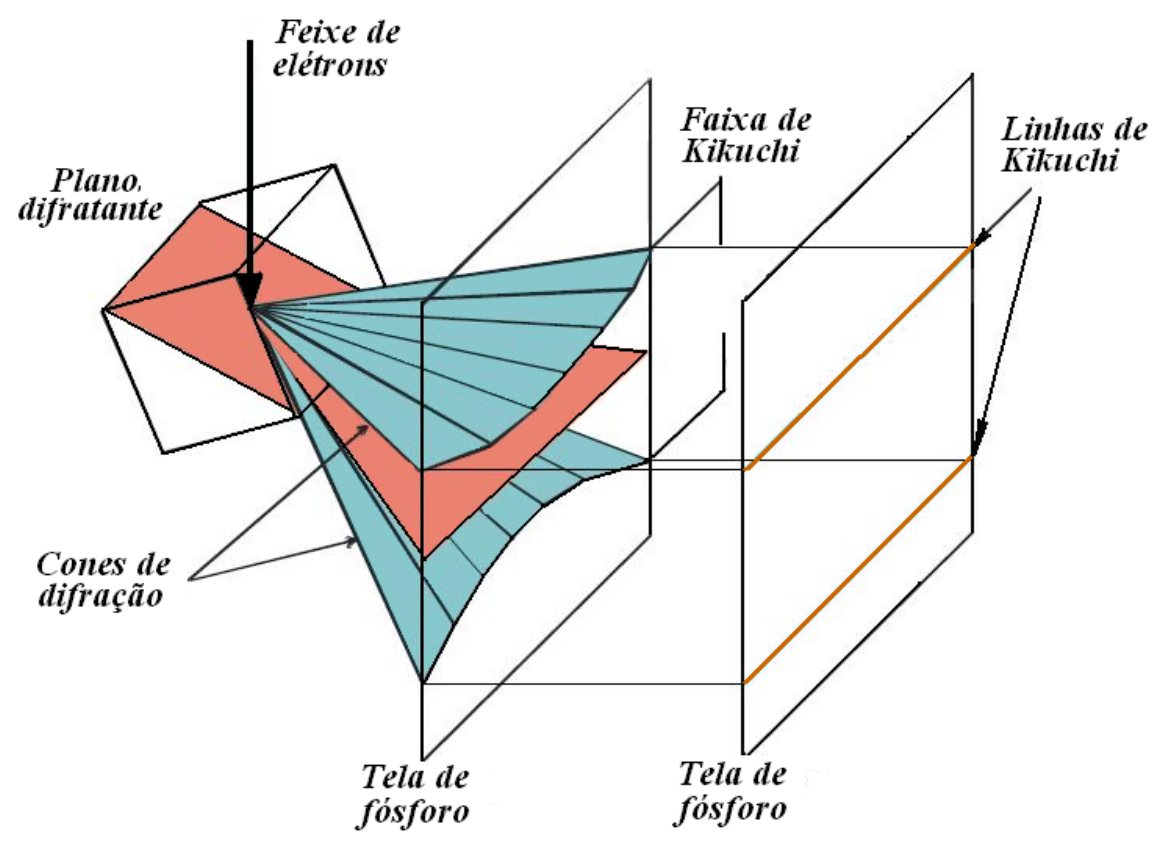

Figura 2.11: Geração das linhas de Kikuchi a partir dos cones formados pelos elétrons retroespalhados (COURTAS et al., 2006)

\subsubsection{Aplicações da técnica EBSD}

Mapas de distribuição de orientação cristalográfica OIM: Os mapas OIM informam acerca da orientação cristalográfica (textura) grão a grão da região analisada por esta técnica. Em materiais sem deformação, comumente, estes mapas apresentam uma homogeneidade de cores dentro de um mesmo grão; porém em amostras deformadas, a qualidade das imagens diminui a medida que se aumenta a deformação. A qualidade da imagem de um mapa OIM é medida pelo índice de confiança (IC), o qual pode variar de 0 a 1 . Estudos mostraram (TSL-INC, 2003) que para um material CFC, os padrões indexados com índice de confiança maiores do que 0,1 têm uma probabilidade de $95 \%$ de estarem indexados corretamente, como é mostrado no gráfico da figura 2.12 .

Os erros de indexação são um problema comum em cristais de baixa simetria como os minerais, porém em metais cúbicos, o erro de indexação é raro se o sistema está bem calibrado e os pontos não indexados aparecem como um pixel isolado no mapa de orientação. Tais pontos podem ser re-indexados (com ajuda do software da TSL) através de um procedimento matemático conhecido como "clean-up", aumentando-se o índice de confiança originalmente obtido. Geralmente pontos com IC abaixo de 0,1 são re-indexados por este método.

O programa permite fazer cinco tipos de limpeza dos dados não indexados, porém o mais utilizado é aquele que permite a correlação com o IC dos grãos 


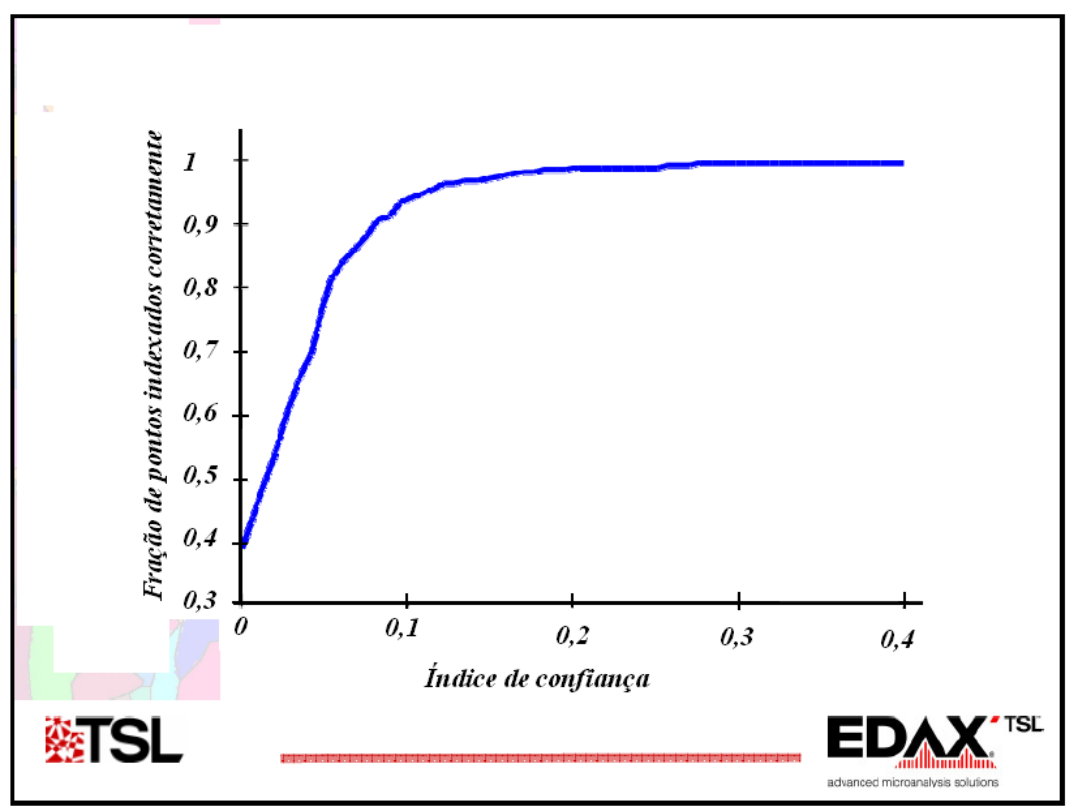

Figura 2.12: Variação do IC durante uma varredura EBSD (TSL-INC, 2003).

vizinhos. Por exemplo, se um ponto particular tem um IC menor do que o valor mínimo, o programa lê os IC's dos pontos ao seu redor para encontrar o vizinho com o IC mais alto. Tanto a orientação quanto o IC do ponto particular são modificados para aqueles valores do ponto vizinho que tem índice máximo. A figura 2.13 apresenta de forma esquemática este procedimento, em que as cores representam a orientação e os números em cada hexágono são os índices de confiança.

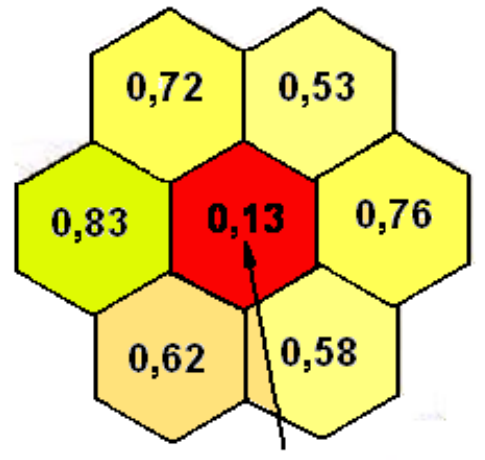

Ponto a ser reindexado

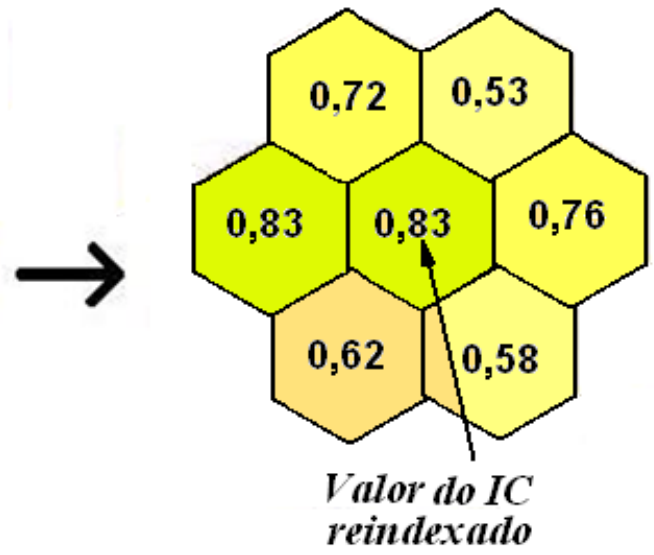

Figura 2.13: Artifício matemático usado pelo software TSL para re-indexar portos com baixo IC (TSL-INC, 2003)

A orientação cristalográfica de cada grão da superfície analisada é obtida com ajuda do programa computacional (Orientation imaging microscopy) (OIM), que acompanha o sistema EBSD. Este programa atribui uma cor diferente para cada orientação cristalográfica do plano paralelo a área analisada, como mostrado na figura 2.14 (a). A cor atribuída para cada orientação cristalográfica 
é obtida a partir de uma figura de pólo inversa PF, em que os grãos aparecem caracterizados em função da sua orientação, em uma escala de cores de diferentes tons, representada por um triângulo unitário de referência, como o apresentado na figura 2.14 (b).

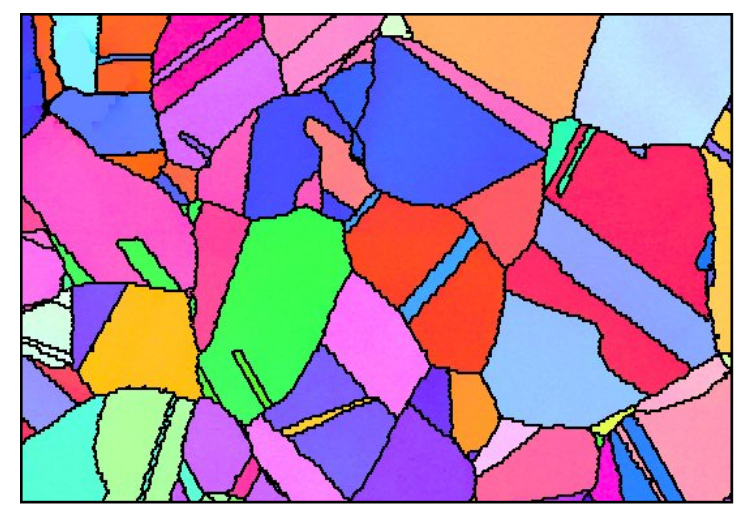

(a)

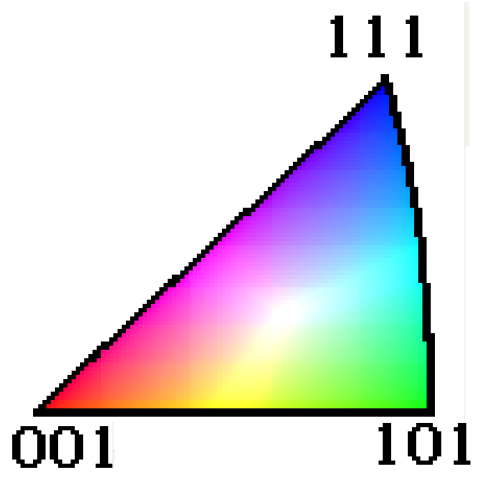

(b)

Figura 2.14: Mapa OIM de distribuição de orientações cristalográficas de um aço inoxidável austenítico (a) e triângulo unitário de referência das cores utilizadas (b).

\subsubsection{Perfil de diferença de orientação}

Esta ferramenta permite obter a diferença de orientação cristalográfica (desorientação) entre dois ou mais grãos, medida ao longo de uma linha teste traçada no mapa OIM na área varrida. A diferença de orientação pode ser analisada de duas formas: ponto-a-ponto e ponto-a-origem.

Em relação aos contornos de grão, estes são classificados como contornos de baixo ângulo, se a desorientação é inferior a $15^{\circ}$, e de alto ângulo se a desorientação é maior do que $15^{\circ}$ (CALLISTER, 2006). Esta classificação permite observar a estrutura do contorno de grão de materiais de difícil ataque, ou até de contornos de subgrão. A ferramenta é usada por pesquisadores no estudo de regiões fragmentadas por deformação plástica, para distinguir bandas de escorregamento e maclas, a partir dos ângulos de desorientação envolvidos, permitindo assim a distinção de estruturas antes confundidas no microscópio ótico. Por exemplo, contornos de macla apresentam desorientação de $60^{\circ}$. Isto ocorre quando maclas de recristalização, em materiais $\mathrm{CFC}$, podem ser caracterizadas com uma rotação de $60^{\circ}$ sobre o eixo de direção $\langle 111\rangle$ Isto significa que uma rotação de $60^{\circ}$ em torno da direção cristalina $\langle 111\rangle$ de um grão trará o reticulado deste grão em coincidência com o reticulado cristalino do grão vizinho. (WRIGHT; FIELD, 1998). Um exemplo do perfil de diferença de orientação é mostrado na figura 2.15 . 


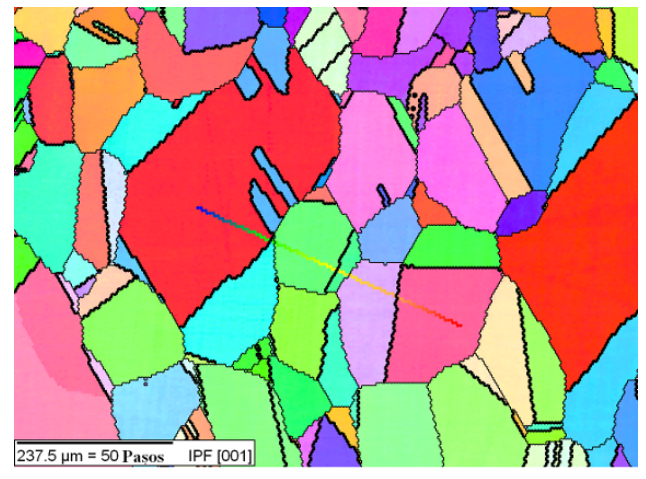

(a)

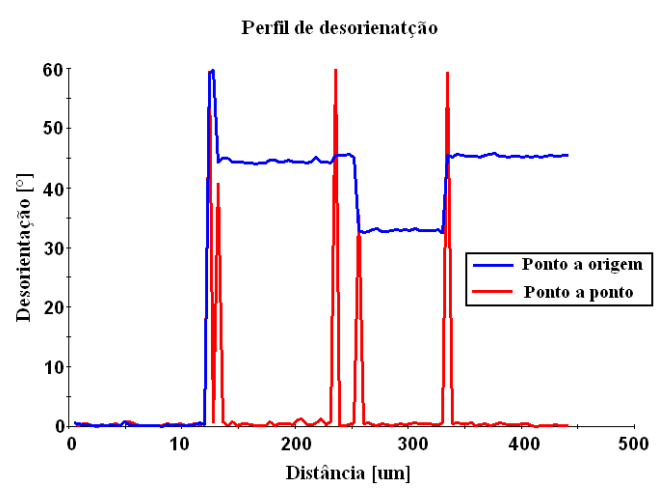

(b)

Figura 2.15: (a) Mapa OIM mostrando a linha teste através da qual se quer saber a diferença de orientação cristalográfica entre os grãos por onde passa .

(b) Perfil de diferença de orientação referente a linha teste .

No mapa OIM da figura 2.15 (a), os contornos de grão desenhados mais espessos correspondem aos contornos de macla, podendo ser verificado na figura 2.13 (b) que a desorientação deste tipo de contornos é de $60^{\circ}$ como informado acima.

\subsubsection{Contornos de grão}

Os contornos de grão podem ser classificados como não especiais e especiais. Os primeiros não têm nenhuma relação de coincidência entre as orientações cristalinas dos grãos que o conformam, sendo classificados como contornos de baixo ângulo < $5^{\circ}$ e de alto ângulo $>15^{\circ}$. Em relação aos contornos especiais, também conhecidos como contornos de coincidência (coincidence site lattice, CSL), estes são formados quando os reticulados cristalinos de dois grãos vizinhos (que apresentam certa desorientação, porém a mesma estrutura cristalina) são superpostos formando um novo reticulado com os átomos coincidentes (reticulado de coincidência), como o apresentado na figura 2.16 .

Os reticulados de coincidência, formados nos contornos de grão, são denotados pelo símbolo $\Sigma$. Este parâmetro indica a relação entre o volume da célula unitária CSL em relação ao volume da célula unitária original, ou equivalentemente $\Sigma$ é descrito como o recíproco dos sítios de coincidência, os quais são caracterizados por números ímpares. Por exemplo, se de cada três átomos superpostos, um deles coincide, o contorno será chamado $\Sigma$-3 e assim por diante.

Contornos associados com baixo valor de $\Sigma$, geralmente $<29$, são de interesse do ponto de vista tecnológico (RANDLE; EngleR, 2000). Por exemplo $\Sigma-3$, que corresponde a um contorno muito especial conhecido como macla, que é um tipo 


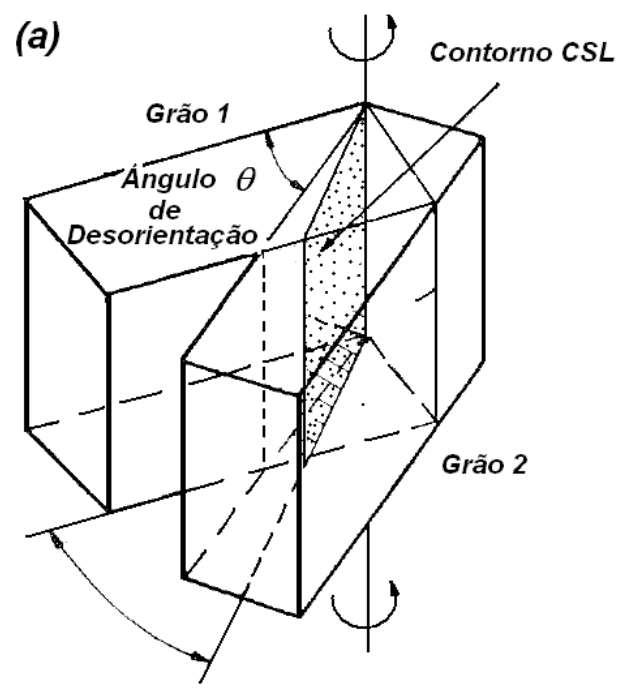

(b)

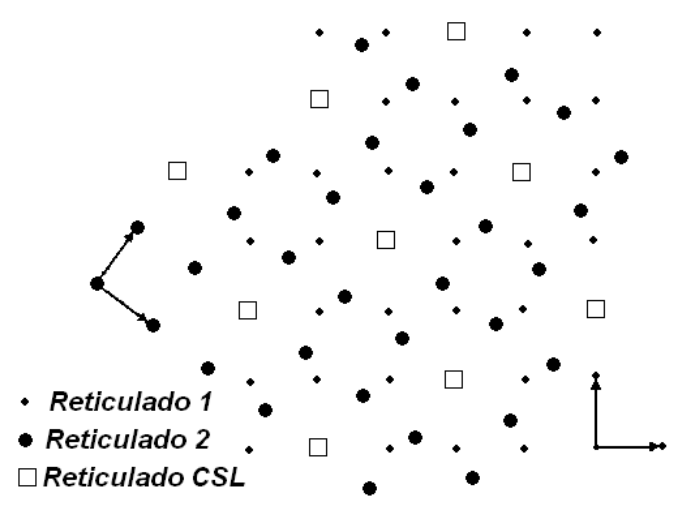

Figura 2.16: Formação de uma estrutura local de coincidência CSL (fronteira) (interpenetração teórica) de dois reticulados vizinhos desorientados por $\theta / U V W$, onde $\theta$ e UVW são o ângulo e o eixo de desorientação, respectivamente. (Por simplicidade um limite inclinado é representado) (a). Representação bidimensional do contorno CSL (b) (RANDLE; ENGLER, 2000)

de contorno presente em materiais de baixa energia de defeito de empilhamento, como os aços inoxidáveis austeníticos. Os contornos especiais de macla são fortemente associados com propriedades especiais como resistência à corrosão e ao desgaste (LIN et al., 1995). Na figura 2.17 apresenta-se um mapa de contornos de grão onde é possível observar a presença tanto de contornos não especiais quanto de especiais.

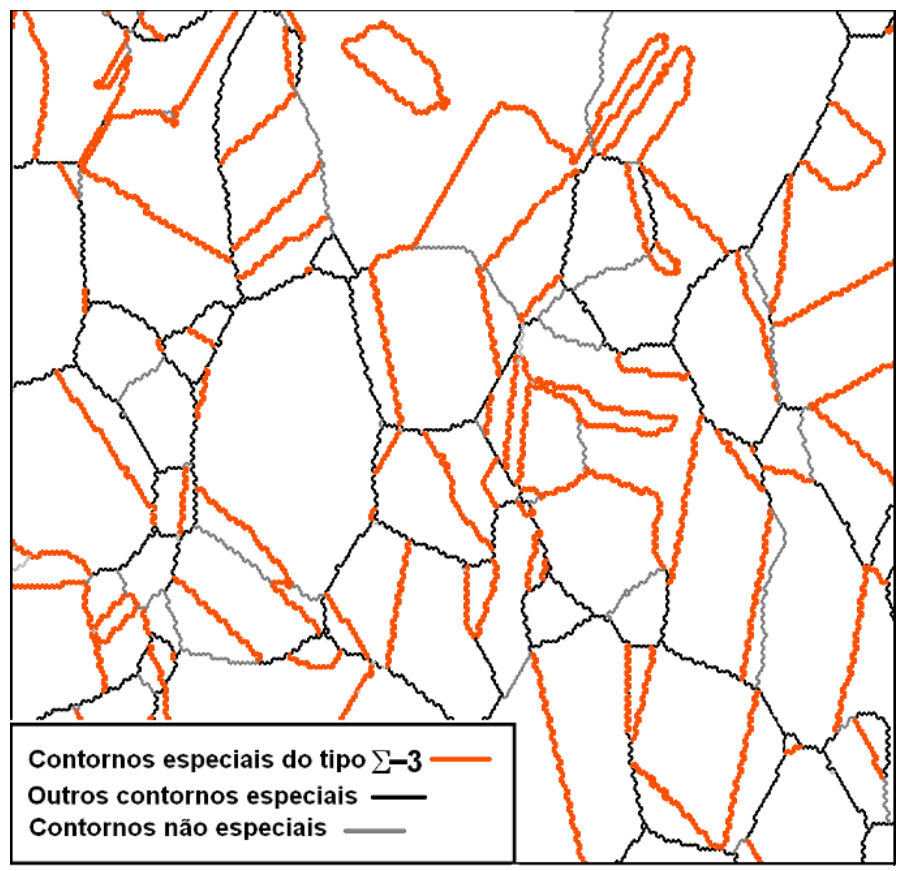

Figura 2.17: Classificação dos contornos de grão em especiais e não especiais no aço $318 \mathrm{HTGN}+$ Sol. 


\subsubsection{Medidas de tamanho de grão}

O tamanho de grão calculado pelo software TSL é especificado como o número de pontos contidos dentro do grão. Alternativamente o software permite a escolha de cálculo do tamanho de grão, por área ou por diâmetro. O diâmetro de um grão particular é calculado por determinação da sua área assumindo que o grão é um círculo. O diâmetro é então igual a duas vezes a raiz quadrada da área dividida por $\pi$. Outro resultado importante relacionado com tamanho de grão é a possibilidade de obter a distribuição de tamanhos. Os resultados obtidos através do software OIM/TSL para medição do tamanho de grão são apresentados nas figuras 2.18 (a) à (c).

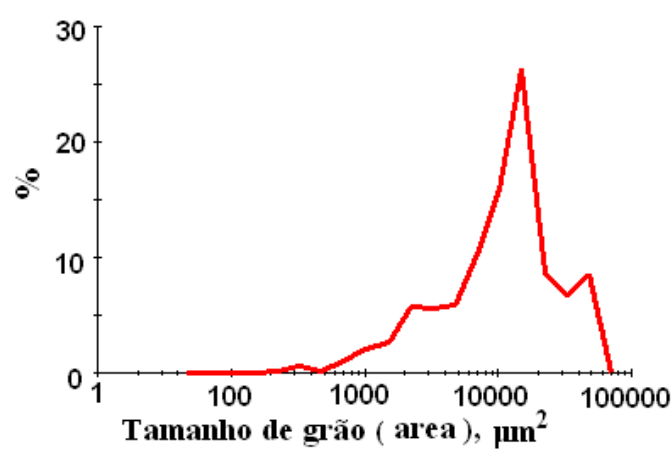

(a)

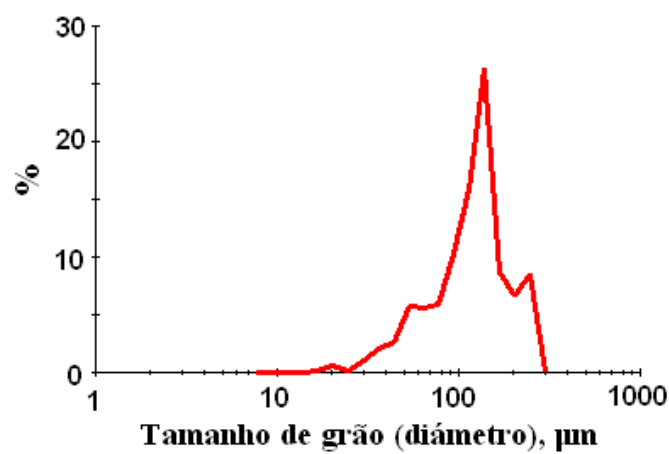

(b)

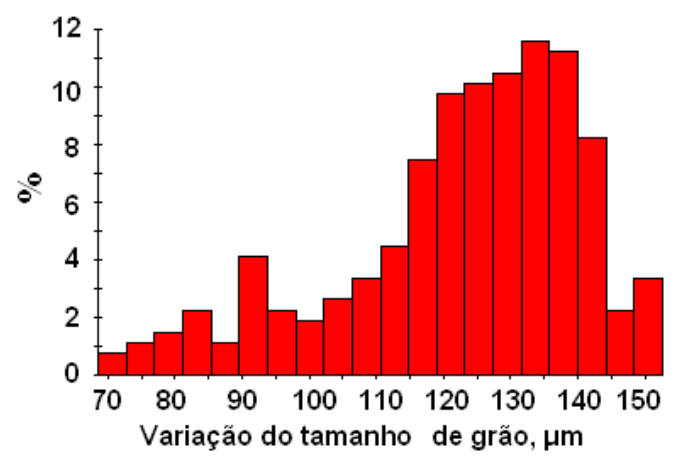

(c)

Figura 2.18: Medição do tamanho de grão, (a) em área, (b) em diâmetro e (c) como distribuição de tamanhos (TSL-INC, 2003)

\subsubsection{Medidas do fator de Taylor ( FT) e do fator de Schmid (FSch):}

O programa computacional OIM permite determinar os fatores de Schmid e Taylor para cada grão dentro da área analisada por EBSD. Estas tensões podem atuar de forma paralela, normal ou transversal à direção de laminação do material.

O FT descreve a resistência de um grão que irá sofrer fluência, sendo que quanto maior o valor do FT, maior deve ser a força necessária para iniciar a 
deformação. O FT se baseia na hipótese de que há deformação por escorregamento ao longo de planos cristalinos específicos. Para calcular o FT deve-se conhecer o sistema de escorregamento, a orientação cristalográfica e a simetria do cristal, juntamente com o estado de tensões.

Os fatores de Taylor ou Schmid se baseiam na orientação do sistema de escorregamento relativo ao estado de tensão. De certo modo o mapa do FT ou do FSch espelha o mapa de orientações (mapa OIM), ilustrando a capacidade do programa OIM para relacionar a orientação cristalográfica com alguma propriedade do material, tal como a fluência.

Os resultados dos fatores de Schmid e Taylor obtidos através do software TSL/OIM, podem estar em forma numérica, em função das coordenadas de cada ponto varrido dentro da área analisada,ou na forma de mapas, onde cada grão corresponde uma cor em função da intensidade da tensão atuante nele e da sua orientação cristalográfica. Um exemplo de um mapa de estado de tensões em que se calcula o fator de Taylor de cada grão em uma amostra com uma tensão uniaxial de compressão paralela à direção de laminação é apresentado na figura 2.19 (a) e na figura 2.19(b) se apresenta o mapa OIM correspondente ao mapa em (a).

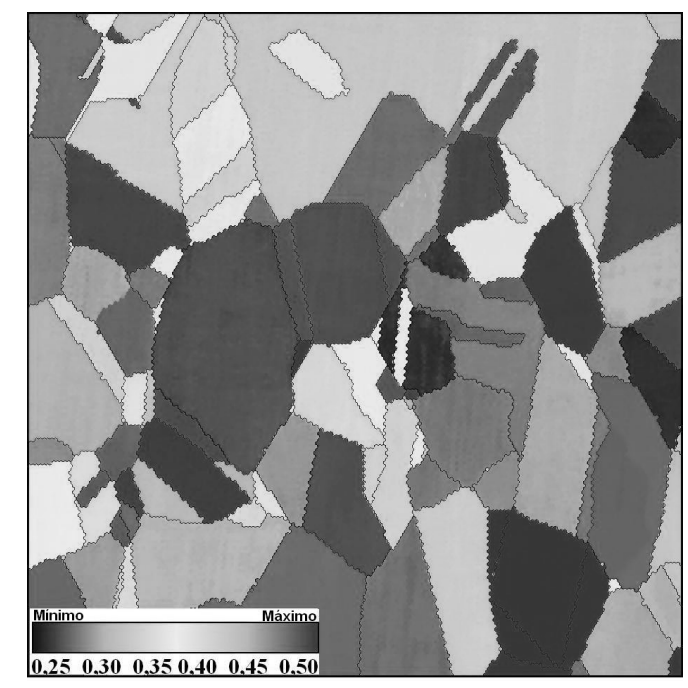

(a)

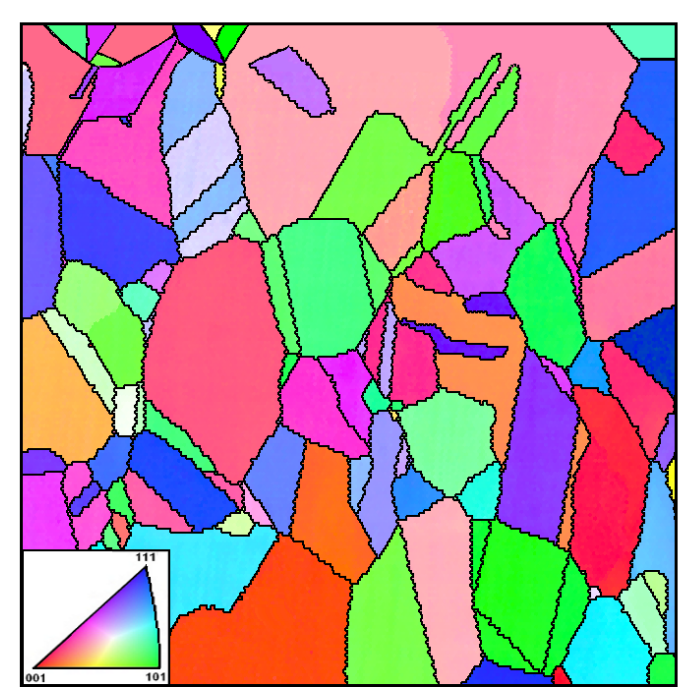

(b)

Figura 2.19: Mapa da variação do fator de Taylor (a) em uma amostra carregada em compressão normal ao plano que contém a direção de laminação com sua respectiva escala de valores. (b) mapa OIM. 


\subsubsection{Orientação cristalográfica (análise da textura crista- lográfica)}

A textura cristalográfica pode ser definida como a orientação preferencial dos grãos, isto é, a tendência estatística de que os cristais ou grãos de um material policristalino estejam orientados em uma ou mais orientações particulares (GARVART; MONTHEILLET, 2000; HUMPRHEYS; HATHERLY, 1996). É frequente o uso do termo textura aleatória para expressar ausência de orientação preferencial. A figura 2.20 (a) e (b) mostra a orientação das células unitárias dentro dos grãos onde não existe textura, figura 2.20 (a) e onde sim existe, figura 2.20(b).

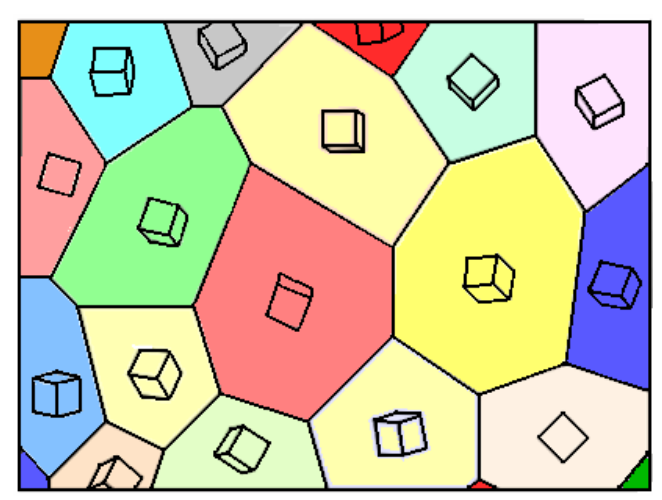

(a)

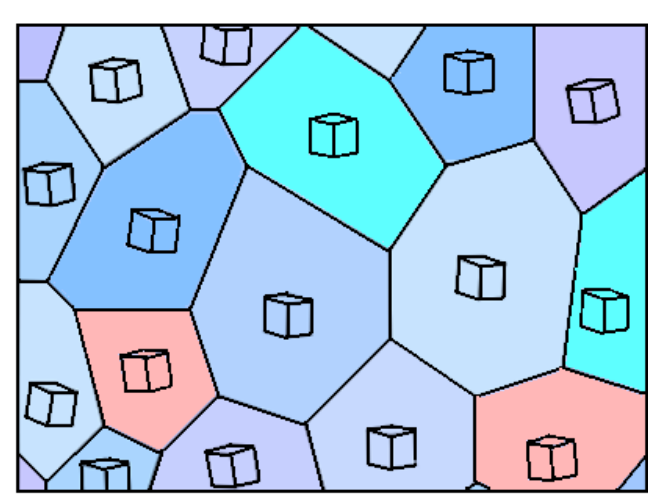

(b)

Figura 2.20: Representação da orientação cristalográfica grão a grão em uma amostra (a) com textura aleatória e (b) texturada (TSL-INC, 2003).

Propriedades físicas e mecânicas como módulo de Young, resistividade, tenacidade, ductilidade, permeabilidade magnética, condutividade elétrica, expansão térmica e estampabilidade são bastante dependentes da textura cristalográfica (RANDLE; ENGLER, 2000)

A textura normalmente se indica na forma de componentes $\{h k l\}\langle u v w\rangle$, em função da família de planos atômicos localizados paralelos à superfície varrida por EBSD e pela direção cristalográfica preferencial na que apontam esses planos. As componentes são representadas por uma orientação cristalográfica ideal, próxima a orientação de um razoável número de grãos agrupados na região estudada. Para o caso de uma placa laminada, uma escolha conveniente de eixos coordenados é aquela que leva em conta a direção de laminação DL ou RD (de Rolling Direction), a direção transversal (DT) e a direção normal à superfície da placa (DN), sendo esses eixos perpendiculares entre eles. Desta forma, o plano cristalino representado por $\{h k l\}$ é paralelo ao plano da placa, e a direção $\langle u v w\rangle$, que pertence ao plano $\{h k l\}$, é tomado paralelo à direção de laminação. Portanto, a posição das células unitárias dentro do grão se fixa com 
relação aos eixos DL, DT e DN da placa. A figura 2.21 (a) mostra a representação da componente de textura $\{001\}\langle 110\rangle$, conhecida como textura de cubo rodado.

Para o caso de produtos cilíndricos como uma barra trefilada, as componentes de textura são representadas pelas direções $\langle u v w\rangle$, paralelas a direção axial da barra, em torno do qual os grãos se organizam. Essas direções são normais aos planos $\{h k l\}$ localizados na seção reta da barra, como pode ser visto na figura 2.21 (b). Este tipo de textura se conhece como textura de fibra. No exemplo da figura 2.21 (b) pode se observa que a textura de fibra inclui vários planos atômicos $\{h k l\}$, contendo a direção $\langle 100\rangle$ (CHIN, 1985; HUMPRHEYS; HATHERLY, 1996).
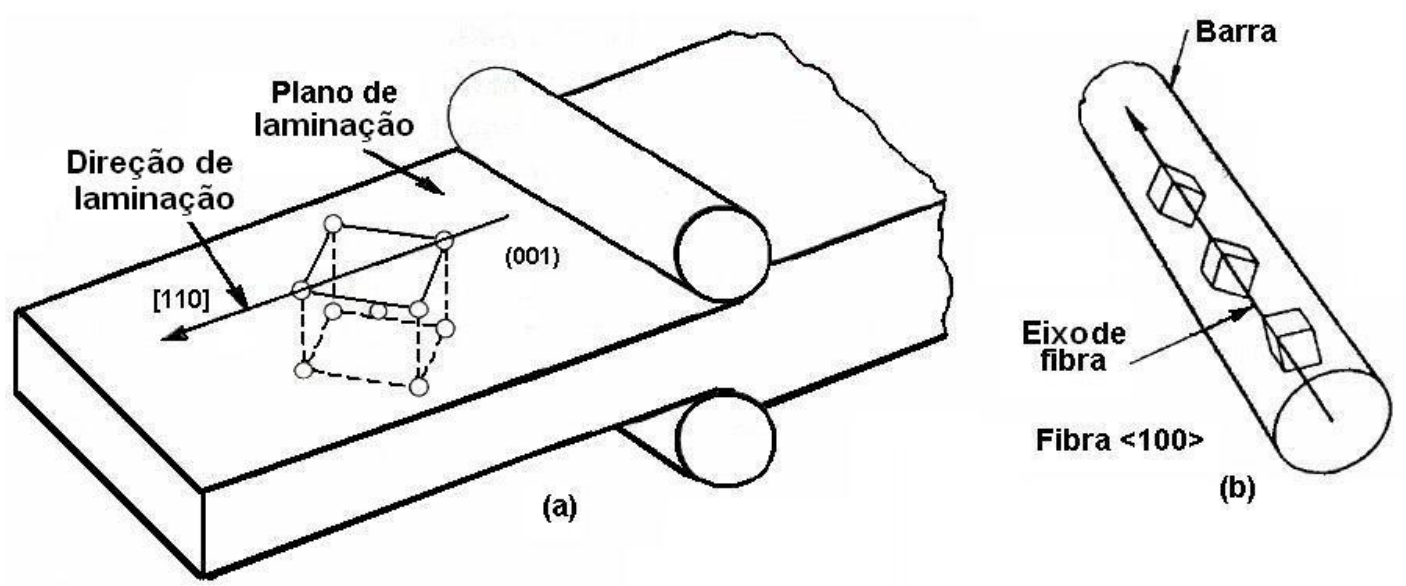

Figura 2.21: (a) Componente de textura $\{001\}\langle 110\rangle$ em uma placa e (b) textura de fibra $\{h k l\}\langle 100\rangle$ em uma barra trefilada (CHIN, 1985)

A textura pode ser introduzida em um material por diversos procedimentos como tratamentos térmicos, processos de fabricação, fundição, deposição de filmes protetores, por deformação, entre outros. O estudo da textura de um material envolve uma parte qualitativa quando se determinam as direções preferenciais de orientação e uma parte quantitativa quando se determina a fração de volume associado a essa orientação preferencial (CHIN, 1985; LIMA; LIMA; PADILHA, 2003).

No que diz respeito a engenharia, a textura é propriedade importante quando se deseja aumentar a anisotropia de algumas propriedades mecânicas e elétricas, daí a necessidade de controlar esta propriedade no material.

\subsubsection{Métodos de representação da textura}

Existem vários métodos para representar a textura, sendo necessário determinar antes as orientações dos grãos. Convencionalmente a textura é descrita através de figuras de pólo. O método mais tradicional para determinar a textura de um material tem sido a difração de raios-X, no entanto a técnica EBSD tem 
alcançado importância devido a que permite correlacionar microestruturas, fazer relações entre grãos vizinhos e determinar à textura de grande quantidade de grãos de uma vez de modo automático e com grande velocidade.

Figuras de pólo: Uma figura de pólo é uma projeção estereográfica que mostra a distribuição de uma direção cristalográfica particular do conjunto de grãos que fazem parte de uma amostra. Uma figura de pólo contem algumas direções de referência relacionadas com a conformação do material, por exemplo, a direção de extrusão (D) em arames ou as direções de laminação (DL ou RD) e as direções transversal (DT) e normal (DN) à direção de laminação contida no plano da chapa. A figura de pólo também pode ser representada como um conjunto de pontos como se mostra na figura (figura 2.22) (b) (GODEC; JENKO, 2000). No caso de textura aleatória, os pólos se distribuem uniformemente na projeção, porém se existe textura como tal, os pólos aparecem ao redor de algumas orientações preferenciais, deixando as demais áreas desocupadas (figura 2.22) (b). Geralmente a direção de laminação (RD) é posicionada na parte superior da esfera ou do círculo que representa a figura de pólo. Já a direção transversal (TD) e posicionada à direita, e a direção normal (ND) ao plano da placa é posicionada no centro do círculo ou da esfera (SCHWARTZ; KUMAR; ADAMS, 2000).
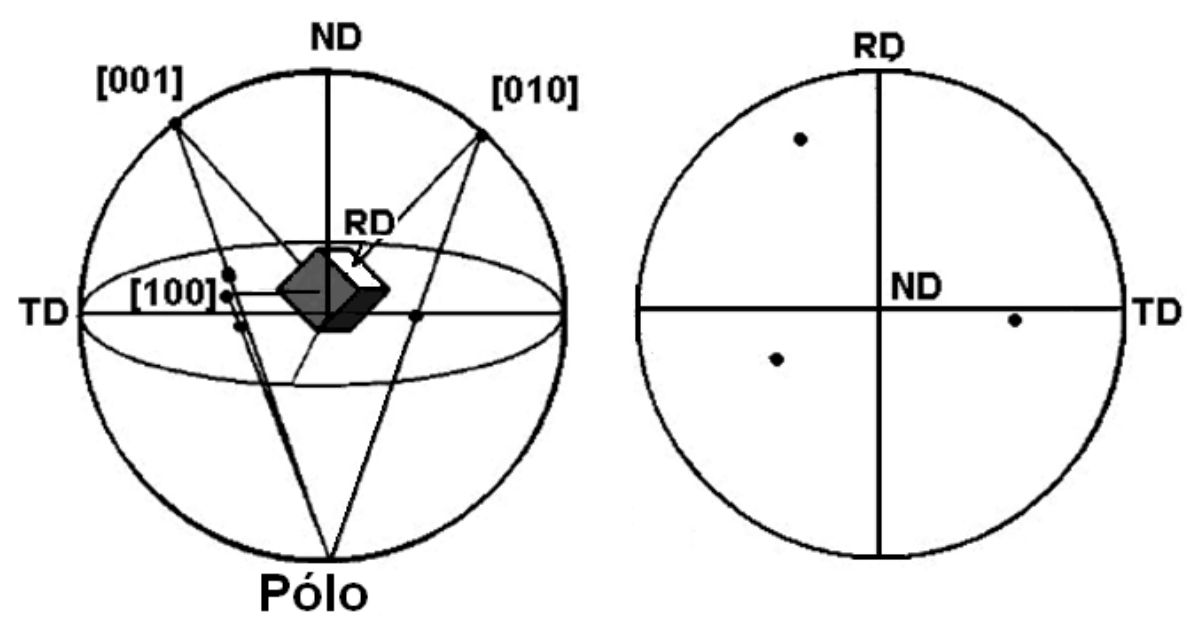

Figura 2.22: (a) Família de pólos 001 de um cristal cúbico representados em uma projeção estereográfica e (b) família de pólos do cristal (BUNGE., 1993)

Figura de pólo inversa (IPF): Em uma figura de pólo inversa, como a apresentada na figura 2.23, se registra a densidade de pólos dos planos hkl, paralelos a uma superfície dada da amostra sobre um triângulo característico, do sistema cristalino do material. Conhece-se como figura de pólo inversa porque é 
a normal à superfície a que varre o triângulo de orientações na busca de aquelas que representam a textura (BUNGE., 1993).

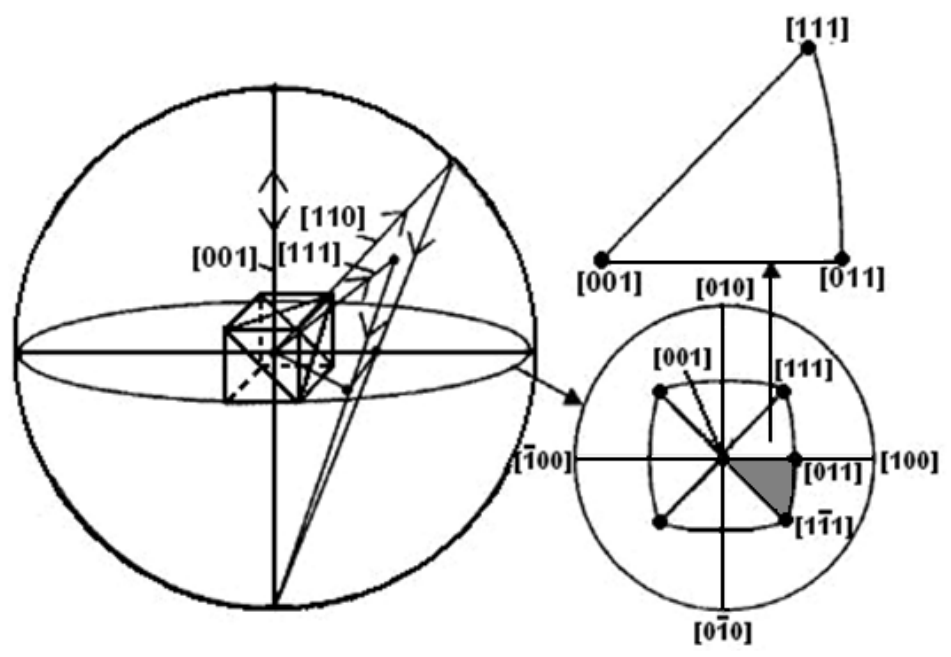

Figura 2.23: (a). Figura de pólo inversa obtida através de uma projeção estereográfica (BUNGE., 1993; RANDLE; ENGLER, 2000)

Outros métodos para descrever a textura de um material, como a função de distribuição de orientação (ODF), podem ser consultados nas referências (RANDLE; ENGLER, 2000; SCHWARTZ; KUMAR; ADAMS, 2000). 


\section{Objetivos}

\subsection{Objetivo geral}

O objetivo do presente trabalho é avaliar os mecanismos de desgaste erosivo por cavitação, na escala do tamanho de grão (meso-escala), operantes durante ensaios de cavitação vibratória, para diferentes amostras de aços inoxidáveis austeníticos ligados ao nitrogênio. Pretende-se examinar tanto estruturas austeníticas convencionais, com teores superficiais de nitrogênio próximos a 0,9\%-massa, quanto estruturas de "austenita expandida" com teores superficiais de nitrogênio próximos a $20 \%$ - massa.

\section{$3.2 \quad$ Objetivos específicos}

1. Obter amostras de aços inoxidáveis de elevado teor de nitrogênio (0,9\%massa), com estrutura austenítica. e amostras com estruturas de austenita expandida com cerca de $20 \%$ - massa.

2. Obter, por meio de tratamentos termoquímicos e termomecânicos de um aço inoxidável dúplex UNS S31803, dois conjuntos de amostras austeníticas com teor de nitrogênio em solução sólida de aproximadamente 0,9 \% massa que apresentem acentuadas diferenças de textura, tamanho de grão e distribuição de tipos de contornos de grão.

3. Caracterizar a microestrutura, a microtextura e a mesotextura das amostras de estudo, por meio de microscopia eletrônica de varredura (MEV) e difração de elétrons retro-espalhados (EBSD).

4. Caracterizar a resistência à cavitação vibratória em água destilada das amostras de estudo, e comparar os resultados obtidos com amostras de comparação: aço dúplex UNS S31803 solubilizado, aço austenítico UNS S30403 solubilizado e liga à base de cobalto Stellite-6 (bruta de fusão). 
5. Caracterizar as superfícies desgastadas, por meio de análises no MEV, identificando os mecanismos de desgaste para diferentes tempos de ensaio de cavitação vibratória.

6. Estudar, comparativamente, o efeito da microestrutura, da textura e do teor de nitrogênio na importância relativa dos mecanismos de desgaste identificados nas diversas etapas dos ensaios de cavitação vibratória.

7. Estudar, comparativamente, o efeito da orientação cristalográfica de grãos individuais na resistência à deterioração induzida pela erosão por cavitação.

8. Estudar, comparativamente, o efeito da desorientação entre grãos e do tipo de contorno de grão (diferentes tipos de contornos CSL e contornos Não CSL) na resistência à deterioração induzida pela erosão por cavitação. 


\section{Materiais e Métodos}

O aço inoxidável dúplex UNS S31803, também conhecido como URANUSß $45 \mathrm{~N}(\mathrm{UR} 45 \mathrm{~N})$ e que será chamado neste trabalho de aço inoxidável 318, foi inicialmente submetido a tratamentos termoquímicos de nitretação gasosa em alta temperatura (High Temperature Gas Nitriding-HTGN), a $1200{ }^{\circ} \mathrm{C}$, por 8 horas e pressão do gás $N_{2}$ de uma (1) atmosfera e nitretação a plasma em baixa temperatura (Low Temperature Plasma Nitriding - LTPN), a $400{ }^{\circ} \mathrm{C}$ e atmosfera de $75 \% N_{2}: 25 \% H_{2}$ por um tempo de 12 horas. Esses tratamentos visavam a obtenção de camadas austeníticas de alto teor de nitrogênio em solução sólida formadas sobre os materiais a estudar. Para este trabalho foram utilizadas amostras finas (aproximadamente 1,5 $\mathrm{mm}$ de espessura) e tempos longos de tratamento (8 horas) com o qual obteve-se uma estrutura homogênea de austenita com alto teor de nitrogênio na amostra toda. Após a nitretação gasosa, várias das amostras do aço 318 foram submetidas a tratamentos térmicos de solubilização e termomecânicos (laminação seguida de recozimento para recristalização), com o intuito de modificar a estrutura austenítica e obter materiais com diferentes microestruturas. Esses materiais foram depois submetidos a ensaios de desgaste EC com o intuito de avaliar os mecanismos de desgaste operantes nos diferentes estágios do processo de EC. Para os ensaios foi utilizado o método indireto de cavitação vibratória, em que amostras, planas, foram colocadas embaixo da ponta vibratória a $0,5 \mathrm{~mm}$ de distância.

As várias condições de tratamento utilizadas permitiram classificar os diferentes materiais em tipos, sendo estes:

(a) aços inoxidáveis de estrutura completamente austenítica e solubilizados;

(b) aços inoxidáveis de estrutura completamente austenítica e encruados;

(c) aços inoxidáveis de estrutura austenítica contendo dispersão de nitretos;

(d) aços inoxidáveis com estrutura completamente austenítica, com uma camada adicional de estrutura de austenita expandida; e 
(e) materiais de comparação: foram usados materiais convencionais como o aço inoxidável austenítico 318 no estado como recebido CR e que neste trabalho será chamado 318 CR; o aço inoxidável austenítico UNSS30403 (AISI $S A E 304 L)$ no estado solubilizado e que neste trabalho será chamado de aço inoxidável 304L Sol. Também foi usada a superliga de cobalto Stellite-6 no estado como recebido (bruta de fundição). Os materiais utilizados como comparação são comumente utilizados em aplicações onde o desgaste por cavitação é um problema frequente. Para o aço 318CR não foram avaliados os mecanismos de desgaste, esta condição só será usada para comparar a variação da taxa de desgaste dos diferentes demais materiais.

O aço inoxidável dúplex 318 foi escolhido para realizar este estudo já que é possível transformá-lo, através do tratamento HTGN, em um aço austenítico de alta estabilidade microestrutural, isto é, não sofre facilmente transformação de fase martensítica induzida por deformação. Devido ao seu alto teor de cromo é possível obter por nitretação gasosa em alta temperatura um elevado teor de nitrogênio em solução sólida próximo de $1 \%$, teor que nos aços da família dos inoxidáveis austeníticos, fica em torno de $0,5 \%$ de $\mathrm{N}$ em solução sólida.

É sabido que aços inoxidáveis austeníticos convencionais, por possuírem austenita metaestável, transformam-se facilmente em martensita quando submetidos à deformação. No que diz respeito ao aço inoxidável 304L, este foi escolhido para comparação por possuir microestrutura austenítica, que é a estrutura que se quer avaliar além de ser um material muito usado em peças submetidas à cavitação. Com relação à superliga de cobalto Stellite-6, esta foi selecionada porque tipicamente possui uma das maiores resistências ao desgaste erosivo por cavitação já reportadas (HATTORI; MIKAMI, 2009).

Para avaliar os mecanismos de desgaste operantes durante os ensaios de cavitação e caracterizar os materiais utilizados, foram usadas as técnicas de microscopia eletrônica de varredura e difração de elétrons retroespalhados (Electron Backscattered Diffraction - EBSD). A técnica EBSD permitiu relacionar a severidade do desgaste com algumas características cristalográficas dos materiais utilizados, como a orientação cristalográfica dos grãos, tipo de contornos de grão e o fator de Taylor. Este fator permitiu ter uma ideia da capacidade de deformação dos grãos quando são aplicadas tensões (tração ou compressão), em diferentes direções do material. 


\subsection{Materiais utilizados}

\subsubsection{Materiais no estado como recebido}

Características iniciais dos materiais no estado como recebido, a partir dos quais se obtiveram as diferentes amostras:

- (a) o aço inoxidável 318 na forma de placas laminadas a quente de $9 \mathrm{~mm}$ de espessura,

- (b) o aço inoxidável 304L na forma de chapas laminadas a quente e recozidas de $3 \mathrm{~mm}$ de espessura, e

- (c) Stellite-6 na forma de placas de $5 \mathrm{~mm}$ de espessura.

Os materiais utilizados neste trabalho, bem como as suas composições químicas nominais são apresentados na tabela 4.1. A composição química de cada aço foi informada pelo fabricante, razão pela qual será chamada de composição química nominal.

Tabela 4.1: Composição química nominal dos aços utilizados.

\begin{tabular}{|c|c|c|c|c|c|c|c|c|c|c|}
\hline \multicolumn{10}{|c|}{ Material } & \multicolumn{8}{|c|}{ Elementos químicos (\% em peso) } \\
\hline UNS & AISI & $\mathrm{Cr}$ & $\mathrm{C}$ & $\mathrm{Ni}$ & $\mathrm{Mo}$ & $\mathrm{Mn}$ & $\mathrm{Si}$ & $\mathrm{Cu}$ & $\mathrm{N}$ & $\mathrm{S}$ \\
\hline S31803 & - & 22,5 & 0,019 & 5,4 & 3,0 & 1,9 & - & 0,14 & 0,16 & 0,001 \\
\hline S30403 & 304L & 18,7 & 0,03 & 9,6 & - & 1,9 & 0,95 & - & - & 0,02 \\
\hline \hline \multicolumn{2}{|c|}{$\begin{array}{l}\text { Superliga } \\
\text { Stellite-6 }\end{array}$} & $\mathrm{Cr}$ & $\mathrm{C}$ & $\mathrm{Ni}$ & $\mathrm{Mo}$ & $\mathrm{Mn}$ & $\mathrm{Si}$ & $\mathrm{Co}$ & $\mathrm{W}$ & $\mathrm{Fe}$ \\
\cline { 2 - 11 } & 30,0 & 1,2 & 3,3 & 1,5 & 1,0 & 2,0 & $\mathrm{Bal}$ & 4,5 & 3,0 \\
\hline
\end{tabular}

\subsection{Tratamentos térmicos, termoquímicos $\mathrm{e}$ termomecânicos}

Na sequência serão apresentados os diferentes tipos de tratamentos realizados nas amostras, para obter os 5 tipos de materiais estudadas.

\subsubsection{Nitretação gasosa em alta temperatura (HTGN)}

Amostras quadradas (1,7 x 1,7 $\mathrm{cm}$ de lado e de 1 a $1,5 \mathrm{~mm}$ de espessura) do aço 318 foram nitretadas a gás em alta temperatura $\left(1200{ }^{\circ} \mathrm{C}\right)$, em uma atmosfera gasosa de $N_{2}$ de alta pureza $(99,999 \%$ ), sob uma pressão de 1,0 atm e um tempo de nitretação de 8 horas. As amostras foram previamente lixadas, utilizando 
lixas d'água, mantendo a seguinte sequência de desbaste: 100, 220, 400 e 600 mesh. Posteriormente as amostras foram lavadas com água e sabão de maneira a evitar contaminações que poderiam dificultar a entrada de nitrogênio no aço. As amostras foram aquecidas sob vácuo de aproximadamente $6,5 \times 10^{-5}$ atm, a uma taxa de aquecimento de $0,5^{\circ} \mathrm{C} / \mathrm{s}$ em um forno de retorta horizontal marca Lindberg, aquecido por resistências elétricas, esquematizado na figura 4.1 (a). Nas figuras 4.1 (b) e (c) são apresentados em detalhe os subsistemas de vácuo e entrada de gases. A limpeza da atmosfera no interior da retorta é garantida ao se fazer várias purgas (pressurização com argônio até atingir níveis de pressão positivos e despressurização através do sistema de vácuo). As purgas são realizadas enquanto a temperatura do sistema atinge o valor de tratamento. O resfriamento final foi realizado em água por têmpera direta.

O tratamento de nitretação gasosa em alta temperatura foi realizado com o objetivo de:

(1) transformar o aço inoxidável 318, de estrutura dúplex (austenita e ferrita), em um aço de estrutura $100 \%$ austenítica, contendo ou não nitretos, em função da temperatura e da pressão do gás $N_{2}$ utilizada. Isto graças ao efeito estabilizador da austenita do nitrogênio;

(2) obter um aço com alto teor de $\mathrm{N}$ em que as condições de temperatura e pressão utilizadas permitiram alcançar um teor aproximado de 0,9\% de $\mathrm{N}$ em massa e camadas de até $1 \mathrm{~mm}$ de espessura. Como as amostras utilizadas têm uma espessura de aproximadamente $1,5 \mathrm{~mm}$, espera-se obter uma estrutura austenítica, homogênea, de alto teor de nitrogênio em toda a seção transversal do material; e

(3) melhorar a resistência ao desgaste por EC dos aços inoxidáveis nitretados.

As condições de temperatura e pressão foram calculadas para o aço 318, de tal forma a se obter um material com alto teor nitrogênio em solução sólida. Tais condições foram definidas usando o diagrama de fases para este aço obtido através do programa Thermocalc (C), usando a base de dados TCFE/ 2000, e apresentado na figura 4.2, onde (a) representa as condições para obter uma estrutura austenítica em solução sólida e (b) representa as condições para obter uma estrutura austenítica com nitretos precipitados.

Para as amostras do aço 318, nas quais se queria obter uma microestrutura austenítica livre de precipitados, a cada duas horas de tratamento à temperatura 


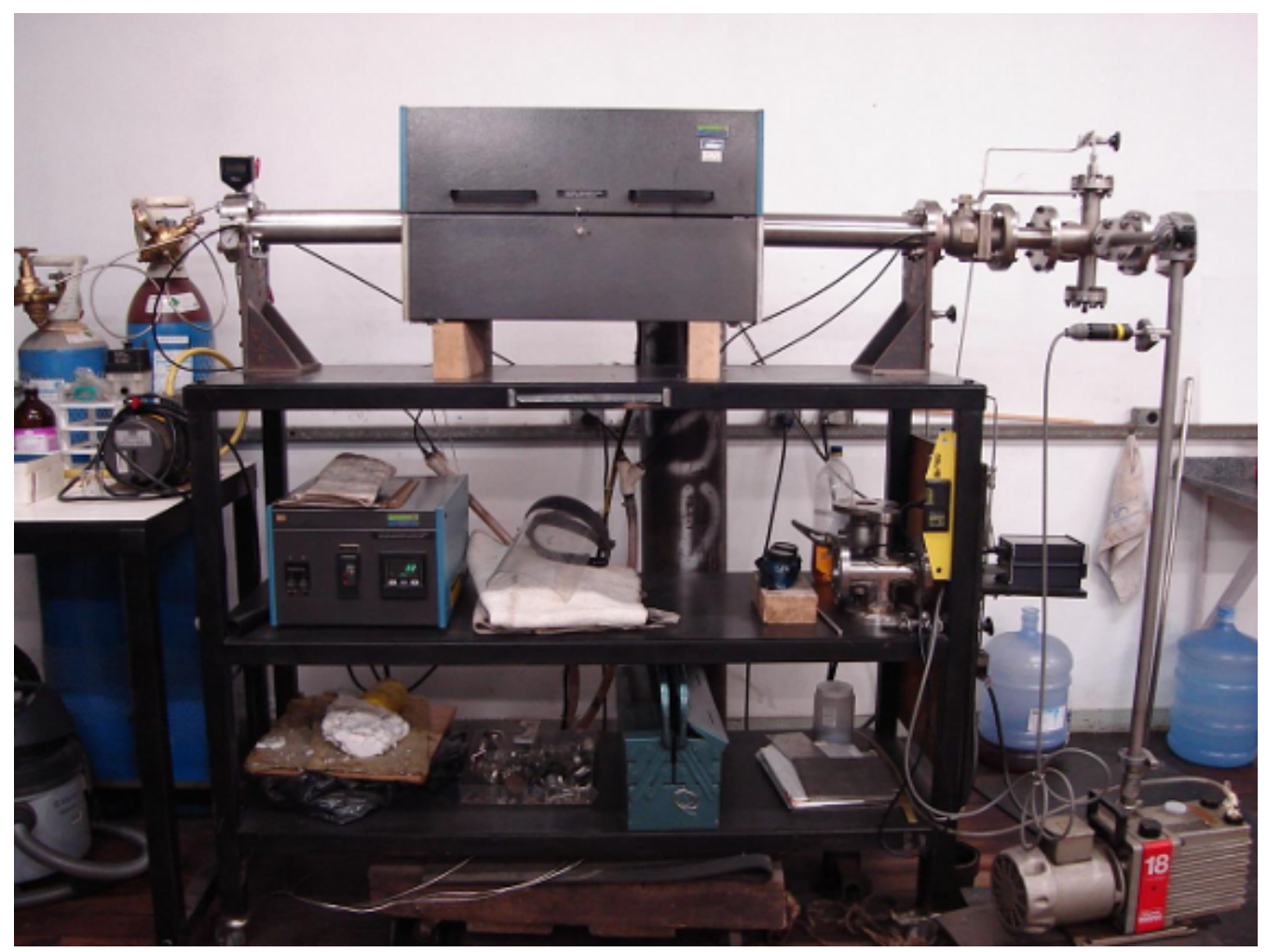

(a)

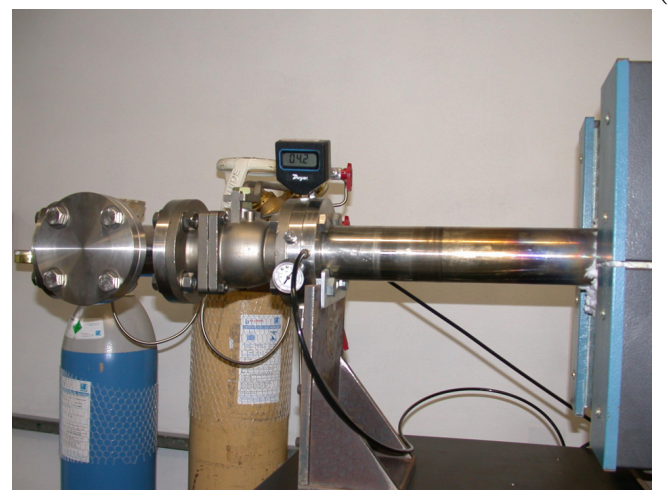

(b)

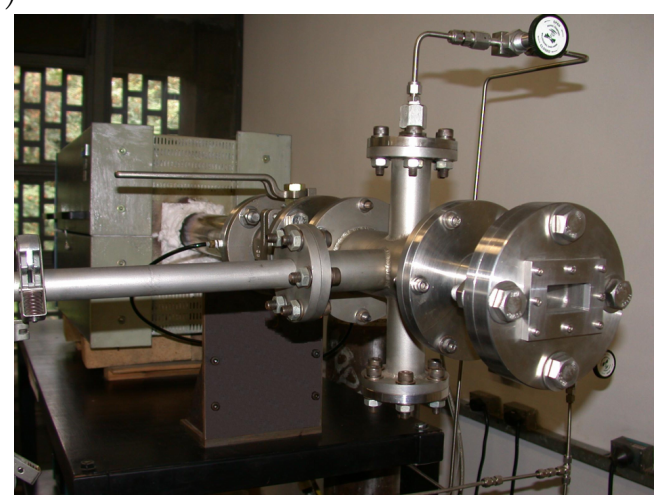

(c)

Figura 4.1: Equipamento utilizado na realização dos diferentes tratamentos térmicos e termoquímicos. (a) sistema geral, (b) subsistema de entrada de gases e controle da pressão e (c) subsistema de entrada de amostras e manipulação do vácuo.

de $1200{ }^{\circ} \mathrm{C}$, foi realizado vácuo por 15 minutos com o fim de dissolver possíveis nitretos ou carbonitretos formados durante o tratamento.

Verifica-se na figura 4.2 , que para uma temperatura de $1200{ }^{\circ} \mathrm{C}\left(1473{ }^{\circ} \mathrm{K}\right)$ linha (a), e uma pressão do gás $N_{2}$ de 1 atm, o teor de nitrogênio a obter deve ser de aproximadamente $0,9 \% N$ em massa

O teor de nitrogênio na superfície das amostras foi determinado por meio de microanálise química WDS com detector Oxford acoplado a um microscópio textitCambridge Instruments Stereoscan 440, por procedimento desenvolvido por 


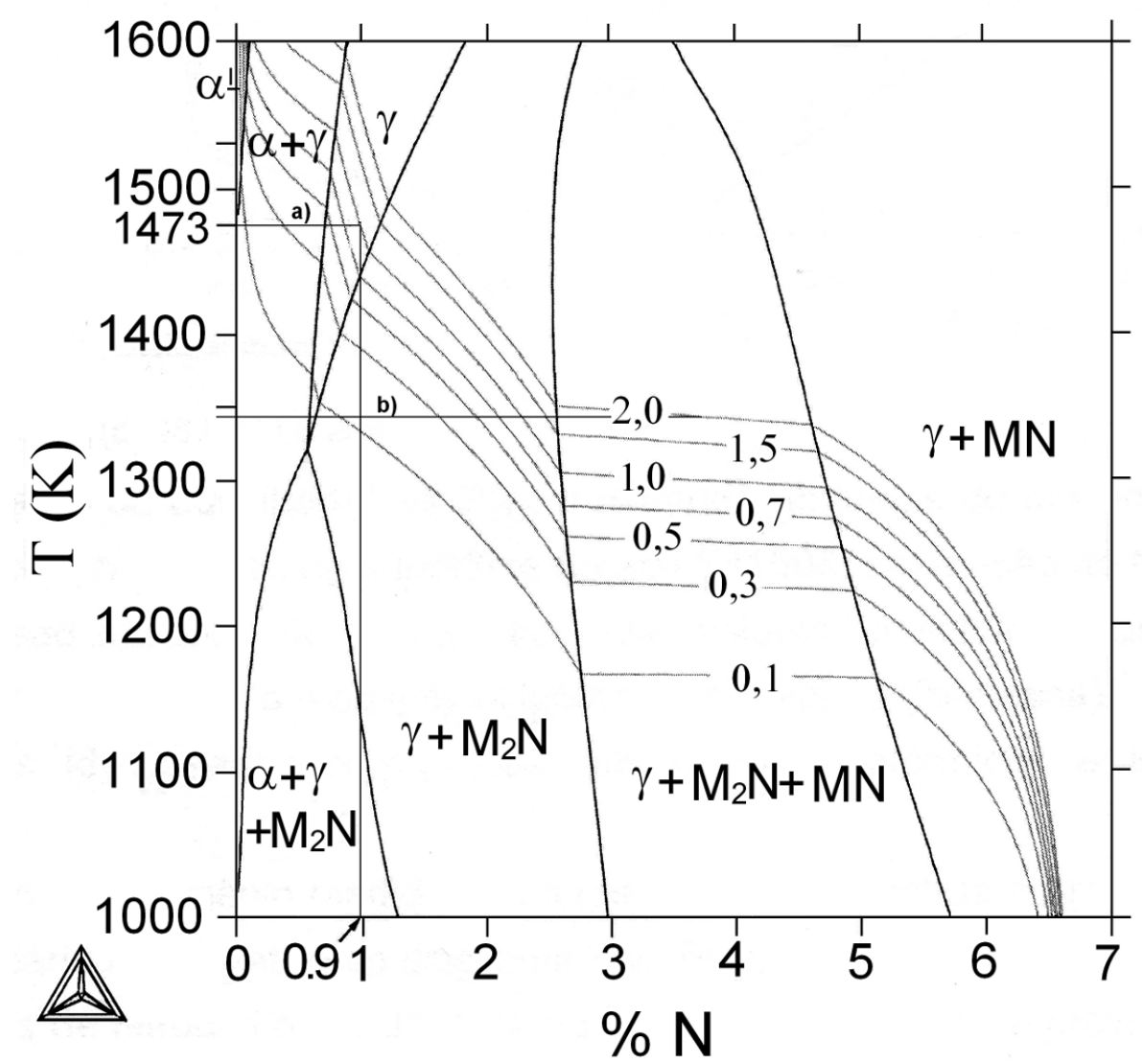

Figura 4.2: Isopletas do diagrama de fases do aço inoxidável UNS S31803, calculado no programa Thermocalc (C). O conjunto de linhas traçadas desde a parte superior esquerda até a parte inferior direita do diagrama corresponde ao equilíbrio com gás $N_{2}$ em diferentes pressões.

Toro, (TORO; TSCHIPTSCHIN, 2010).

A partir das amostras nitretadas a gás em alta temperatura foram obtidas três amostras que fizeram parte do primeiro e segundo tipos de aços inoxidáveis austeníticos com alto teor de nitrogênio.

O primeiro tipo, chamado de "aços inoxidáveis de estrutura completamente austenítica e solubilizados", foi ensaiado em desgaste EC sob duas condições:

(1) nitretada a gás em alta temperatura $\left(1200{ }^{\circ} \mathrm{C}, 8\right.$ horas, 1 atm de $N_{2}$ ) e solubilizada $\left(1200{ }^{\circ} \mathrm{C}, 1\right.$ hora, 1 atm de $\left.N_{2}\right)$ ), a qual foi chamada de 318HTGN+Sol (amostra 1). A solubilização posterior à nitretação foi realizada com o intuito de aumentar o tamanho de grão austenítico e comparar o efeito desta variável na resistência ao desgaste por erosão cavitação, e

(2) nitretada a gás em alta temperatura $\left(1200{ }^{\circ} \mathrm{C}, 8\right.$ horas, 1 atm de $\left.\left.N_{2}\right)\right)$ ), posteriormente laminada a frio até atingir uma deformação de aproximadamente $30 \%$ de redução da espessura e solubilizada $\left(1200{ }^{\circ} \mathrm{C}, 1\right.$ hora, 1 atm de 
$N_{2}$ ) a qual foi chamada de 318HTGN+Lam+Sol, isto é, aço inoxidável 318, nitretado, laminado e solubilizado, (amostra 2). A laminação a frio foi realizada no Hall Tecnológico Prof. Dr. Carlos Dias Brosch do PMT-EPUSP, usando laminador marca Eletrauri. A laminação seguida de solubilização destas amostras promove a rescristalização dos grãos deformados, resultando em grãos austeníticos poligonais, contendo maclas de recozimento e teve como objetivo recuperar o formato equiaxial dos grãos na estrutura deformada, e obter estrutura completamente austenítica.

O segundo tipo, chamado de "aços inoxidáveis de estrutura completamente austenítica e encruados", consistiu de amostras nitretadas a gás em alta temperatura $\left(1200{ }^{\circ} \mathrm{C}, 8\right.$ horas, 1 atm de $\left.N_{2}\right)$ e posteriormente laminados a frio, até atingir uma deformação (redução da espessura) de aproximadamente $30 \%$, porém não solubilizados. Este tipo de aços foi chamado de inoxidáveis de estrutura completamente austenítica e encruados, e identificado como 318HTGN+Enc.

\subsubsection{Nitretação gasosa em alta temperatura com o intuito de formar nitretos}

Trabalhos prévios (BERNS; SIEBERT, 1996; GARZÓN; TSCHIPTSCHIN, 2004) sobre nitretação gasosa em alta temperatura mostraram que quando ocorre precipitação de nitretos a resistência à corrosão é diminuída, porém a resistência a alguns tipos de desgaste pode-se comportar de forma ambivalente (ou aumenta ou diminui), em função das condições de ensaio. Visando avaliar a resistência à cavitação de aços inoxidáveis austeníticos com nitretos precipitados, foi realizada nitretação do aço 318 a $1070{ }^{\circ} \mathrm{C}$ e 2 atm de pressão do gás $N_{2}$ ), por um tempo de 3 horas, condições verificadas pela condição (b) no diagrama de fases apresentado na figura 4.2, e resfriamento em água por têmpera direta. De acordo com o diagrama da Figura 4.2 é de se esperar que o tipo de nitretos precipitados sejam do tipo $\mathrm{CrN}$ e $\mathrm{Cr}_{2} \mathrm{~N}$, entretanto estes nitretos não foram caracterizados. Com estas condições obteve-se o terceiro tipo de amostras a serem submetidas a ensaios de desgaste por EC, conhecidos como aços inoxidáveis de estrutura austenítica contendo dispersão de nitretos e nomeado de 318HTGN+Nit.

\subsubsection{Nitretação a plasma em baixa temperatura}

Visando a obtenção de uma camada de austenita expandida e avaliar o comportamento desta microestrutura frente ao desgaste por cavitação, os aços 
318 e 304L foram submetidos a tratamento superficial de nitretação a plasma em baixa temperatura, a $400{ }^{\circ} \mathrm{C}$ e atmosfera de $75 \% N_{2}: 25 \% H_{2}$, por um tempo de 12 h, num reator de Nitretação a Plasma por arco pulsado, localizado na empresa Heat Tech Ltda, em Mogi das Cruzes, São Paulo.

Antes da nitretação a plasma, o aço 318 foi nitretado a gás em alta temperatura segundo as condições descritas para os aços 318HTGN+Sol e 318 HTGN+Lam+Sol, porém por um tempo de $2 \frac{1}{2} \mathrm{~h}$ e resfriamento final em água por têmpera direta. Essas condições permitiram obter um material com microestrutura duplex (austenita e ferrita) no núcleo e uma camada de austenita de alto teor de $\mathrm{N}$ em solução sólida de aproximadamente $100 \mu \mathrm{m}$ de espessura, sobre a qual foi formada a camada de austenita expandida. Já o aço 304L foi nitretado a plasma nas mesmas condições (após ter sido solubilizado a $1100{ }^{\circ} \mathrm{C}$, por uma hora com resfriamento final em água por têmpera direta).

O tratamento de nitretação a plasma permitiu a obtenção dos dois conjuntos de amostra que constituíram o quarto tipo de materiais estudados em EC, nomeados de 318HTGN+Plas e 304LSol+Plas (amostras 5 e 6).

\subsubsection{Materiais de comparação}

Como já foi dito, para efeitos de comparação foram usados o aço inoxidável 304L, no estado solubilizado, e a superliga de cobalto Stellite-6, no estado como recebido (bruta de fundição). O aço $304 \mathrm{~L}$ foi solubilizado a $1100{ }^{\circ} \mathrm{C}$, por $1 \mathrm{~h}$, com resfriamento final em água por têmpera direta, nomeado como 304LSol.

O segundo material usado para efeito de comparação foi a superliga de cobalto "Stellite-6", selecionado por sua elevada resistência ao desgaste por EC reportada. Estes dois materiais constituíram o quinto tipo de materiais submetidos a ensaios de desgaste por EC (amostras 7 e 8).

Na tabela 4.2 é apresentado um resumo dos diferentes tipos de materiais utilizados neste estudo, assim como a sua identificação, condições de tratamento térmico, termoquímico e termomecânico aos quais foram submetidas as amostras antes dos diferentes testes realizados, bem como características microestruturais e mecânicas como microestrutura e dureza respectivamente. 
Tabela 4.2: Informações referentes a tratamentos térmicos, termoquímicos e termomecânicos, e características macroestruturais e mecânicas dos materiais utilizados neste trabalho.

\begin{tabular}{|c|c|c|c|c|c|c|}
\hline Material & Tipo & $\begin{array}{c}\text { Identificação } \\
\text { da amostra }\end{array}$ & Tratamento & $\begin{array}{l}\text { Microestrutura } \\
\text { da superfície }\end{array}$ & $\begin{array}{l}\text { Dureza } \\
H V 0,1\end{array}$ & $\begin{array}{l}\text { Tamanho } \\
\text { de grão }\end{array}$ \\
\hline \multirow{5}{*}{$\begin{array}{l}\text { UNS } \\
\text { S31803 }\end{array}$} & \multirow[t]{2}{*}{1} & $\begin{array}{l}(1) \\
\text { 318HTGN+ } \\
\text { Sol }\end{array}$ & $\begin{array}{c}\text { Nitretado em } \\
\text { alta } \\
\text { temperatura } \\
\text { com Nitrogênio } \\
\text { em solução } \\
\text { sólida. Aprox. } \\
0,9 \% N \text {. }\end{array}$ & $\begin{array}{l}\text { Austenita com } \\
\text { alto teor de } \mathrm{N} \\
\text { livre de } \\
\text { encruamento e } \\
\text { textura } 110 / / \\
\text { superfície }\end{array}$ & 330 & 160 \\
\hline & & $\begin{array}{l}(2) \\
318 \mathrm{HTGN}+ \\
\text { Lam+Sol }\end{array}$ & $\begin{array}{c}\text { Nitretado em } \\
\text { alta } \\
\text { temperatura, } \\
\text { laminado } 30 \% \text { e } \\
\text { solubilizado. } \\
\text { Aprox. } 0,9 \% N\end{array}$ & $\begin{array}{l}\text { Austenita com } \\
\text { alto teor de } \mathrm{N} \\
\text { livre de } \\
\text { encruamento e } \\
\text { textura } \\
\text { aleatória }\end{array}$ & 330 & 120 \\
\hline & 2 & $\begin{array}{l}(3) \\
\text { 318HTGN+ } \\
\text { Enc }\end{array}$ & $\begin{array}{c}\text { Nitretado em } \\
\text { alta } \\
\text { temperatura e } \\
\text { laminado } 30 \% \text {. } \\
\text { Aprox. } 0,9 \% \mathrm{~N}\end{array}$ & $\begin{array}{l}\text { Austenita com } \\
\text { alto teor de N } \\
\text { encruada }\end{array}$ & 470 & 120 \\
\hline & 3 & $\begin{array}{l}(4) \\
318 \mathrm{HTGN}+ \\
\text { Nit }\end{array}$ & $\begin{array}{c}\text { Nitretado em } \\
\text { alta } \\
\text { temperatura } \\
\text { com nitrogênio } \\
\text { tanto em } \\
\text { solução sólida } \\
\text { quanto } \\
\text { formando } \\
\text { nitretos }\end{array}$ & $\begin{array}{l}\text { Austenita com } \\
\text { alto teor de } \mathrm{N} \\
\text { livre de } \\
\text { encruamento e } \\
\text { com dispersão } \\
\text { heterogênea de } \\
\text { nitretos }\end{array}$ & 330 & 85 \\
\hline & 4 & $\begin{array}{l}(5) \\
\text { 318HTGN+ } \\
\text { Plas }\end{array}$ & $\begin{array}{c}\text { Nitretado em } \\
\text { alta } \\
\text { temperatura e } \\
\text { nitretado a } \\
\text { plasma em } \\
\text { baixa } \\
\text { temperatura. } \\
\text { Aprox. } 20 \% N\end{array}$ & $\begin{array}{c}\text { Austenita } \\
\text { expandida e } \\
\text { textura } 110 / / \\
\text { superfície }\end{array}$ & $\begin{array}{l}1700 \\
\text { HV0.05 }\end{array}$ & 150 \\
\hline $\begin{array}{l}\text { UNS } \\
30403\end{array}$ & 4 & $\begin{array}{l}6) \\
\text { 304LSol+ } \\
\text { Plas }\end{array}$ & $\begin{array}{c}\text { Solubilizado e } \\
\text { nitretado a } \\
\text { plasma em } \\
\text { baixa } \\
\text { temperatura. } \\
\text { Aprox. } 20 \% N\end{array}$ & $\begin{array}{c}\text { Austenita } \\
\text { expandida e } \\
\text { textura } \\
\text { aleatória }\end{array}$ & $\begin{array}{l}1500 \\
\text { HV0.05 }\end{array}$ & 120 \\
\hline$(304 \mathrm{~L})$ & 5 & (7) $304 \mathrm{LSol}$ & Solubilizado & $\begin{array}{l}\text { Austenita sem } \\
\text { adição de N, } \\
\text { livre de } \\
\text { encruamento e } \\
\text { textura } \\
\text { aleatória }\end{array}$ & 180 & 120 \\
\hline $\begin{array}{l}\text { Stellite- } \\
6\end{array}$ & 5 & (8) Stellite-6 & Como recebido & $\begin{array}{l}\text { Matriz de alta } \\
\text { liga com } \\
\text { carbonetos de } \\
\mathrm{W} \mathrm{e} \mathrm{V}\end{array}$ & 660 & - \\
\hline
\end{tabular}




\subsection{Ensaios de cavitação vibratória}

Com o objetivo de avaliar a resistência ao desgaste e os mecanismos de dano que operam nas primeiras etapas do desgaste EC nos diferentes tipos de materiais, foram realizados ensaios de cavitação vibratória conforme a norma ASTM G32 (ASTM-G32, 2009), utilizando a técnica de ensaio indireta, que consiste em colocar o corpo de prova por baixo da ponta vibratória.

Os ensaios foram realizados em equipamento Telsonic SG 1000 operando a $20 \mathrm{kHz}$ de frequência e amplitude de vibração de $40 \mu \mathrm{m}$. As amostras foram colocadas a uma distância de $0,5 \mathrm{~mm}$ da ponta do equipamento. O ambiente de ensaio foi água destilada a $20 \pm 0,5^{\circ} \mathrm{C}$. A massa das amostras foi medida periodicamente, interrompendo os ensaios, com o intuito de quantificar a perda de massa dos materiais ensaiados e levantar curvas de taxa de desgaste em função do tempo de ensaio. Para isto foi usada uma balança Shimadzu AUW220D com resolução de 0,01 mg localizada no Laboratório de Microscopia Eletrônica do PMT-EPUSP.

A figura 4.3 (a) e (b) apresenta fotografias do equipamento de cavitação vibratória utilizado nesta pesquisa. Na figura 4.3 (c) é apresentado um esquema da forma como são colocadas as amostras e as diferentes partes que compõem o sistema. O equipamento está localizado no Laboratório de Fenômenos de Superfície (LFS) no prédio de Engenharia Mecânica da EPUSP.

\subsection{Caracterização microestrutural}

Para a caracterização das amostras foram usadas as técnicas de microscopia óptica, eletrônica de varredura, a difração de elétrons retroespalhados. $\mathrm{Na}$ sequência é apresentado um breve resumo do trabalho realizado com estas técnicas.

\subsubsection{Microscopia óptica}

Esta técnica foi usada para avaliar a microestrutura inicial das diferentes amostras, onde foi possível identificar desde defeitos como inclusões, assim como as fases presentes. A partir de micrografias ópticas também foi possível fazer a quantificação do tamanho de grão utilizando o método proposto na norma ASTM E112 (ASTM-E112, 2004). 

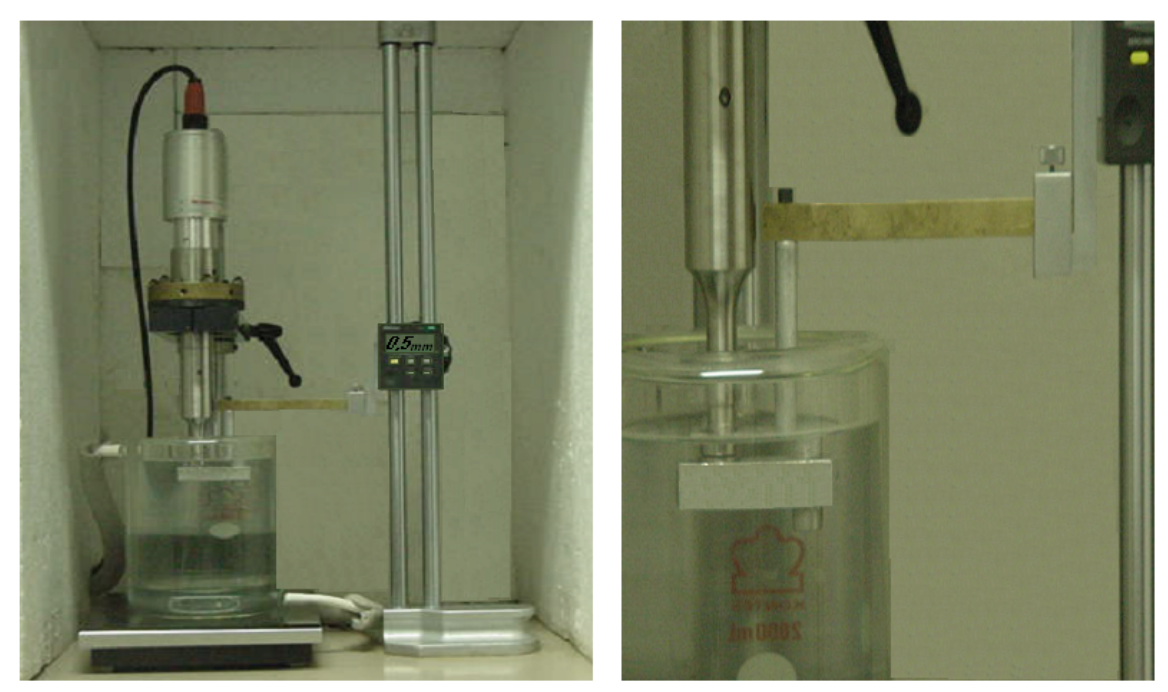

(a)

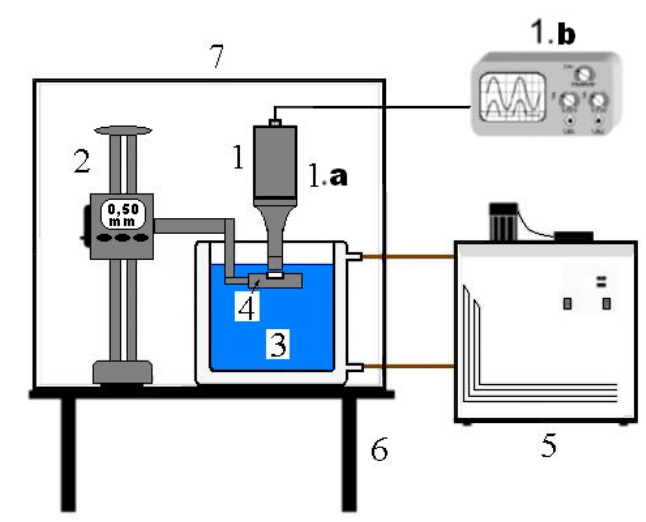

(b)

\begin{tabular}{|c|c|c|}
\hline Item & & Descrição \\
\hline \multirow{2}{*}{1} & \multirow{2}{*}{$\begin{array}{l}\text { Módulo } \\
\text { vbratónio, } \\
\text { TELSONIC SG } \\
1000\end{array}$} & $\begin{array}{l}\text { 1.a. Transdutor e atuador } \\
\text { (titânio). }\end{array}$ \\
\hline & & 1.b. Gerador e controlador. \\
\hline 2. & \multicolumn{2}{|c|}{$\begin{array}{l}\text { Suporte magnético com braço articulado com encaixe } \\
\text { e relógio comparador. }\end{array}$} \\
\hline 3 & \multicolumn{2}{|c|}{ Cuba com falsa parede para refrigeraçäo, 21.} \\
\hline 4 & \multicolumn{2}{|l|}{ Porta amostras. } \\
\hline 5 & \multicolumn{2}{|c|}{ Banho temmostático, Quimis modelo Q-214M2. } \\
\hline 6 & \multicolumn{2}{|l|}{ Suporte. } \\
\hline 7 & \multicolumn{2}{|c|}{ Câmeras de isolação acústica, construção artesanal. } \\
\hline
\end{tabular}

(c)

Figura 4.3: Equipamento de cavitação. (a) vista geral, (b) detalhe do porta-amostra, (c) esquema do dispositivo de ensaios.

\subsubsection{Microscopia eletrônica de varredura (MEV)}

Esta técnica foi utilizada para realizar o estudo morfológico das superfícies ensaiadas através do acompanhamento do desgaste EC. As micrografias foram obtidas a cada vez que os ensaios de cavitação eram interrompidos para medição da perda de massa. Para isto, foi usado um microscópio eletrônico de varredura Philips XL30TMP. Para análises mais simples, como micrografias gerais da microestrutura, antes e após dos diferentes tratamentos térmicos, termoquímicos e termomecânicos, onde se pretendia observar presença de precipitados, óxidos ou inclusões, foi usado um microscópio ótico Olympus (modelo BX60M).

A preparação metalográfica das amostras foi realizada segundo norma ASTM E-407 (ASTM-E407, 2007), isto é, lixamento grosseiro em lixas de grana 220 até 2500, e polimento fino com acabamento final em pano de $1 \mu \mathrm{m}$, utilizando pasta de diamante. 
Para revelar a microestrutura tanto nos aços no estado como recebido, quanto nos aços tratados, foi usada uma solução $10 \%$ em massa de ácido oxálico, através de polimento eletrolítico em equipamento ATMKristall - 620 , localizado no Laboratório de Metalografia do PMT-EPUSP. Os parâmetros usados para o ataque eletrolítico foram $3,5 \mathrm{~V}$ e tempo entre 30 e $40 \mathrm{~s}$, para amostras com tamanho entre 10 e $20 \mathrm{~mm}^{2}$.

\subsubsection{Análise dos mecanismos de desgaste.}

Para cada uma das amostras ensaiadas em EC, foram analisados os mecanismos de dano que operam nas diferentes etapas do desgaste, utilizando microscópio eletrônico de varredura (MEV) para diferentes tempos de ensaio, sempre na mesma área, e dentro dessa área, analisando sempre os mesmos locais. Esta técnica permitiu acompanhar o processo de dano para tempos específicos e para o intervalo de tempo de duração dos ensaios.

As micrografias permitiram observar que tipo de defeitos superficiais, entre pites, bandas de deslizamento ou protuberâncias eram formados para os diferentes tempos de ensaio, identificando os possíveis locais em que diferentes mecanismos de desgaste podiam operar mais facilmente.

\subsubsection{Difração de elétrons retroespalhados}

A técnica de difração de elétrons retroespalhados, EBSD, foi usada para a caracterização da microtextura das amostras 1,2,4,5 e 7 segundo a tabela 4.2, pois essas amostras apresentaram, em experiências preliminares, forte textura.

Para os materiais em que foi possível utilizar a técnica EBSD, ela foi usada para construir mapas de distribuição de orientação cristalográfica, medir o tamanho de grão onde fosse possível, determinar o tipo de contornos de grão, e identificá-los pelo índice de coincidência CSL - Coincidence Site Lattice, utilizando o software OIM Analysis, desenvolvido pela TSL. O sistema usado foi um EBSD/TSL acoplado ao microscópio eletrônico de varredura Philips XL30TM, anteriormente mencionado.

O polimento final das amostras analisadas pela técnica EBSD foi realizado em politriz automática Struers, girando a $250 \mathrm{rpm}$, com uma carga de $300 \mathrm{~g}$, usando sílica coloidal 0,25 $\mu \mathrm{m}$, por no mínimo $1 \mathrm{~h}$. Este equipamento encontrase localizado no laboratório de metalografia do PMT-EPUSP. A preparação do aço 304L foi feita por polimento eletrolítico, devido ao fato deste material 
sofrer transformação martensítica durante o polimento, mesmo sob baixas cargas. Assim sendo, as amostras deste aço foram polidas até lixa $n^{\circ} 600$ mesh e levadas ao sistema de polimento eletrolítico ATM Kristall 620. Para o polimento usou-se uma solução de ácido perclórico (940 ml de etanol (absoluto), $6 \mathrm{ml}$ de água destilada e $54 \mathrm{ml}$ de $\mathrm{HClO}_{4}$, com uma voltagem de $35 \mathrm{~V}$ e um tempo de aproximadamente $40 \mathrm{~s}$. As amostra não precisaram ser atacadas por substâncias químicas, pois o polimento eletrolítico já é suficiente para obter um bom resultado.

Deve-se mencionar que para as amostras do aço 318HTGN+Enc e Stellite-6, não foi possível a realização da varredura EBSD, isto porque o primeiro material apresenta uma estrutura deformada, fato que dificulta a obtenção de padrões de Kikuchi e o segundo uma estrutura bastante complexa. Assim, a discussão sobre os mecanismos de desgaste operantes é feita a luz do que foi observado nas micrografias MEV, não sendo possível fazer uma correlação com a orientação cristalográfica dos grãos desses materiais nem com o tipo de contornos de grão.

\subsubsection{Realização da varredura EBSD e obtenção de mapas.}

Para garantir que o acompanhamento do desgaste EC fosse realizado na mesma área varrida por EBSD, após a preparação metalográfica e com a ajuda de um equipamento de microdureza Vickers, foram feitas quatro marcas (carga de $1 \mathrm{~kg}$ ), de modo a formar uma área retangular, com espaçamento de 1,5 mm de uma marca para outra, sobre a superfície das amostras onde foi realizada a varredura EBSD, como mostra a figura 4.4 .

As diferentes varreduras EBSD foram realizadas com passos variando na faixa de 2 a $4 \mu \mathrm{m}$ entre cada par de pontos analisados, com uma voltagem de $25 \mathrm{kV}$ de aceleração dos elétrons e uma inclinação da superfície de 70 graus devido à geometria do sistema.

\subsection{Relações entre desgaste erosivo por cavitação e parâmetros cristalográficos}

Depois de terminada a varredura EBSD das amostras, os dados foram processados utilizando o programa computacional OIM Analysis, a partir do qual se obtiveram mapas de distribuição de orientação cristalográfica mapas de tipos de contornos de grão Orientation Image Maps - OIM, e mapas dos fatores de Taylor para várias condições de tensão, com os quais foi possível correlacionar o processo de dano decorrente do desgaste EC, com as propriedades cristalográficas de alguns 


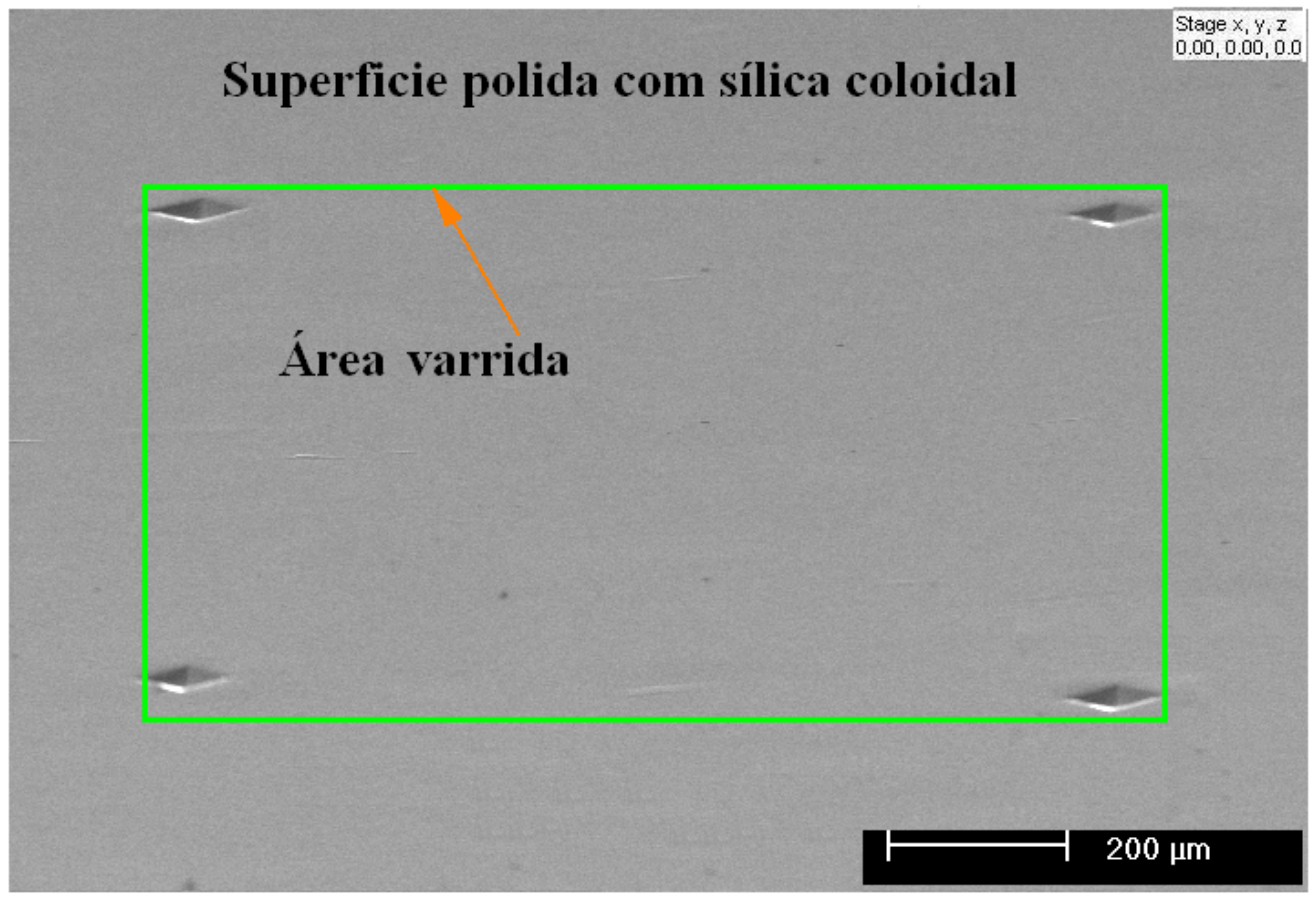

Figura 4.4: Área varrida, demarcada sobre a superfície por meio de endentações Vickers. Foto obtida diretamente do programa EBSD antes da varredura da superfície. A área é quadrada mas a amostra está inclinada $70^{\circ}$, daí a sua assimetria.

dos materiais utilizados. Estas relações são apresentadas na sequência.

\subsubsection{Relação entre desgaste EC, orientação crista- lográfica e FT}

Quando os ensaios de desgaste por cavitação eram interrompidos, as amostras eram pesadas e posteriormente fotografadas no MEV, onde se tinha cuidado de focar sempre a mesma área em que havia sido obtido o mapa de distribuição de orientações cristalográficas OIM. Localizada a área, foram realizadas fotografias gerais (em baixos aumentos), para observar a forma como se apresentava o dano na superfície exposta à cavitação, isto é, se era generalizada ou localizada e quais regiões começavam a ser mais ou menos afetadas (dentre grãos, contornos de grão e defeitos cristalográficos como maclas, bandas de deslizamento, protuberâncias, pites, etc).

Para determinar quais orientações cristalográficas eram mais ou menos afetadas pelo desgaste EC, ao longo do tempo de ensaio, foram inicialmente determinados, de forma visual e com ajuda de micrografias MEV, os grãos que apresentavam a superfície mais conservada ou mais danificada, dentro de uma região da área ensaiada em cavitação. Os grãos identificados como os mais conservados nesta área, foram destacados (pintados em concordância com a cor 
indicada pelo triângulo de referência ou IPF como mostra a figura 2.14 (b)), com ajuda do programa Adobe - Photoshop@. Finalmente foi obtido o mapa OIM, só para os grãos que se apresentavam mais conservados ou mais danificados, de forma a identificar qual ou quais eram as orientações de maior e menor resistência ao desgaste EC através do tempo de ensaio. A identificação dos grãos mais conservados e mais danificados só foi realizada para tempos de ensaio de 4 e 64 horas, nos materiais 318HTGN+Sol e 318HTGN+Lam+Sol (amostras 1 e 2).

Para verificar quais orientações cristalográficas apresentam maior ou menor resistência ao desgaste EC, foram calculados mapas do fator de Taylor, assumindo que as tensões que atuam na superfície, devidas as ondas de choque e microjatos provenientes da implosão de bolhas de cavitação, sejam de compressão uniaxial normal à superfície e que se propagam de forma radial para dentro do material exercendo uma compressão num determinado volume (CUPPARI; SOUZA; SINATORA, 2005; HAMMITT, 1966). Para simular esta condição, foi usado um dos modelos propostos pelo programa TSL/OIM em que a deformação no material é do tipo compressiva, obtida quando uma tensão de compressão, normal à superfície cavitada é exercida, conforme se observa no esquema da figura 4.5. O mapa do FT foi calculado para os dois materiais do tipo 1 (318HTGN+Sol e 318HTGN+Lam+Sol, (amostras 1 e 2)).

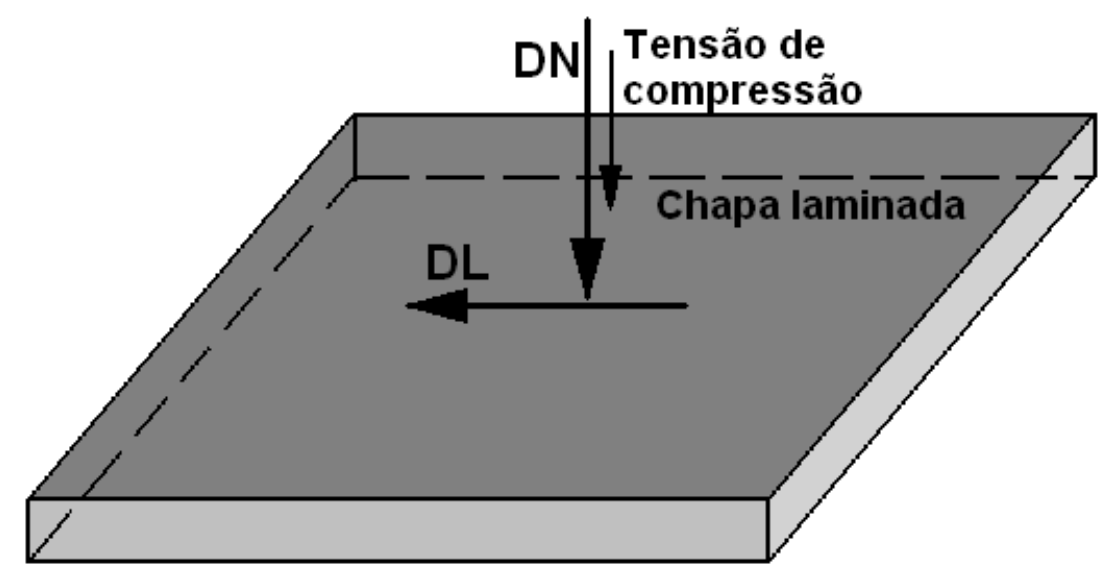

Figura 4.5: Esquema de uma chapa onde se mostra a direção de aplicação da tensão para o cálculo do FT. (DL e DN representam as direções de laminação e direção normal à direção de laminação respectivamente).

Para fazer um acompanhamento mais detalhado do desgaste por EC envolvendo diferentes orientações e tempos de ensaio, foi selecionada uma região dentro do mapa OIM, obtido para o aço 318HTGN+Lam+Sol. contendo aproximadamente 100 grãos. A área sobre a superfície do material ensaiada corresponde com a parte do mapa OIM escolhido foi fotografada no MEV após tempos de ensaio de 4 e 25 horas. O desgaste foi classificado visualmente para 
cada grão dentro daquela área, na faixa de valores de 1 a 5 , em que um valor de 1 indica que o grão manteve um bom estado de conservação para esse tempo de ensaio. $\mathrm{O}$ valor 2 indica que o interior do grão começou a apresentar indícios de dano, e assim por diante, até chegar ao valor de 5, que indica que esses grãos apresentam a maior quantidade de dano observável.

Para cada tempo de ensaio estudado foram obtidos, com ajuda do programa TSL/OIM, mapas OIM somente daqueles grãos pertencentes a cada valor atribuído na classificação realizada, isto é, um mapa contendo só os grãos de valor 1, um mapa contendo só os grãos com valor 2 e assim por diante. Da mesma forma, foram obtidas figuras de pólo inversa, para cada um desses mapas obtidos, de modo a identificar quais as orientações cristalinas eram mais ou menos afetadas pelo desgaste. Desta forma foi possível fazer uma correlação entre desgaste EC e a orientação cristalográfica de cada grão, para os dois tempos analisados.

\subsubsection{Relação entre desgaste erosivo por cavitação e tipo de contornos de grão}

Para realizar este estudo foi utilizado o aço 318HTGN+Lam+Sol (amostra 2). Com ajuda do Software TSL/OIM, foi calculado um mapa de tipos de contornos de grão, em uma área da região cavitada, contendo aproximadamente 220 grãos. Esses contornos foram classificados de acordo com o índice de coincidência de seus reticulados (CSL), como contornos de grão especiais e contornos de grão não especiais. Neste caso foram considerados contornos de grão especiais, aqueles com $C S L<29$. Para a classificação dos contornos, entre especiais e não especiais foi usado o critério de Brandom (RANDLE; ENGLER, 2000). Este critério diz que a região entre dois grãos pode ser classificada como um contorno especial se a tolerância, $\Delta \theta$, na desorientação entre os dois grãos, com índice de coincidência $\left(\sum\right)$, é $\Delta \theta=15^{\circ} \sum^{-1 / 2}$. Entretanto, tenha-se observado que esse critério classifica alguns contornos que não são especiais como especiais como se fossem. Este fato levou a propor um critério mais restrito para a tolerância $\Delta \theta$, proposto por Palumbo e colaboradores (G.PALUMBO et al., 1998). Este critério diz que $\Delta \theta=15^{\circ} \sum^{-5 / 6}$.

Por sua vez, os contornos especiais foram classificados em dois tipos, aqueles com $\sum=3$ nomeados neste trabalho $\sum-3$ (conhecidos como contornos de macla), e aqueles com $\sum \neq 3$ nomeados neste trabalho como outros CSL. Os contornos não especiais foram aqui chamados de Não CSL. Como mencionado no parágrafo anterior, a classificação dos tipos de contornos foi realizada utilizando 
o programa TSL/OIM em uma região dentro do mapa OIM obtido para o aço selecionado. Este procedimento é mostrado na figura 4.6. A região analisada continha aproximadamente 220 contornos dos três tipos, 80 CSL $\sum-3,35$ de outros CSL e 105 Não CSL. O programa também permitiu obter mapas individuais dos contornos $\sum-3$ e dos outros CSL, facilitando a sua contagem e identificação em micrografias MEV. Realizada a classificação dos contornos, estes foram localizados em micrografias MEV das amostras do aço 318HTGN+Lam+Sol ensaiadas em cavitação por 4, 9, 16 e 25 horas. Essas micrografias correspondem com o mapa de tipos de contornos de grão analisado.

A evolução do desgaste por cavitação foi realizada de forma visual, assim, para cada tempo de ensaio analisado foi contabilizado o número de contornos de cada tipo que apresentavam evidências de dano. Para cada tipo de contorno foi calculada a porcentagem de contornos danificados e a sua variação no tempo de ensaio com relação a ele mesmo. Desta forma foi possível construir gráficos da fração de contornos danificados para cada tipo analisado em função do tempo de ensaio. Tempos superiores a 25 horas não foram analisados porque a superfície dos grãos se apresentava tão danificada, que não era possível identificar muitos dos contornos.

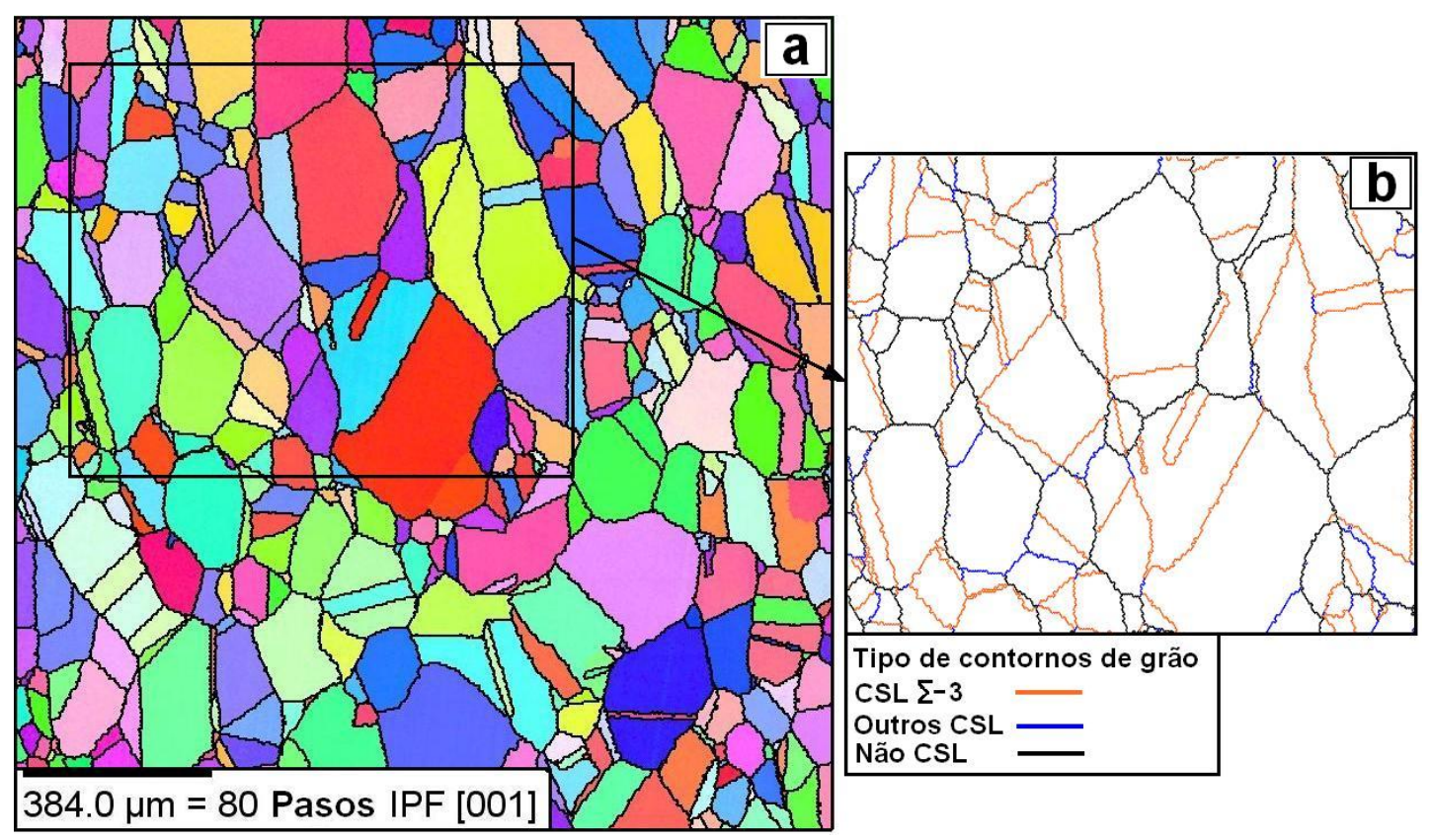

Figura 4.6: Para o aço 318HTGN+Lam+Sol: (a) mapa de distribuição de orientações cristalográficas (OIM), (b) área destaca em (a) usada para classificar os tipos de contornos mostrados no mapa à direita 


\subsubsection{Relação entre orientação cristalográfica, tipo de contornos de grão e Fator de Taylor FT}

Para fazer esta relação foi medida a variação de FT (calculada como a diferença do FT), entre grãos separados por contornos que visualmente se percebiam mais conservados. Neste caso foi utilizada o aço inoxidável 318HTGN+Lam+Sol, pelo fato de apresentar orientação cristalográfica aleatória. Como dito anteriormente, o FT foi calculado através do software TSL/OIM, considerando que as tensões atuantes na superfície desgastada eram de compressão uniaxial normal à superfície da chapa.

A variação do fator de Taylor entre grãos separados por contornos visivelmente conservados foi calculada para um tempo de cavitação 16 horas. Esse tempo foi escolhido porque a superfície apresentava uma quantidade significativa de contornos ainda conservados, sendo que para tempos maiores quase $100 \%$ da superfície apresentava todos os contornos danificados.

Os valores de variação do FT obtidos foram agrupados em 5 intervalos iguais e para cada intervalo foi calculada a fração de contornos visivelmente conservados. A partir dos valores do FT, os grãos adjacentes aos contornos analisados foram classificados como grãos com baixa ou alta diferença de FT. 


\section{$5 \quad$ Resultados e discussão}

Os resultados foram divididos em três partes . Na primeira parte são apresentadas informações gerais dos diferentes tipos de ligas estudados antes de serem submetidos aos ensaios de desgaste EC. Na segunda parte são discutidos os mecanismos de dano operantes durante as diferentes etapas do processo de desgaste EC, para cada uma das ligas estudadas. Por último, na terceira parte são apresentados resultados, onde se relacionam características do desgaste EC com aspectos cristalográficos de alguns dos materiais usados neste estudo.

\subsection{Caracterização dos materiais em estudo}

\subsubsection{Caracterização dos aços inoxidáveis no estado como recebido}

As figuras 5.1 (a) e (b) apresentam micrografias da superfície para os aços inoxidáveis 304L e 318 respectivamente, no estado como recebido. Nessas micrografias é possível identificar, além das fases, a forma e o tamanho dos grãos que estes materiais apresentam.

Da micrografia da figura 5.1 (a), para o aço inoxidável 304L, nota-se que os grãos são do tipo equiaxial e tamanho de grão médio de $35 \mu m$, medido pelo método dos interceptos (GARVART; MONTHEILLET, 2000). A dureza média do material foi de $180 \pm 10 \mathrm{HV}$, medida com carga de 0,1 kgf. Esta micrografia apresenta também algumas regiões escuras, possivelmente, de martensita transformada durante o processo de polimento.

Na microestrutura do aço 304L foram encontradas inclusões não metálicas do tipo sulfeto de manganês, como mostrado na figura 5.2 (a) e verificado pelo espectro de composição EDS, da figura 5.2 (b).

Na figura 5.1 (b), para o aço 318 na condição como recebido, observase microestrutura constituída por grãos alternados de ferrita e austenita (com aproximadamente $50 \%$ em volume de cada fase, confirmado com ajuda do software 


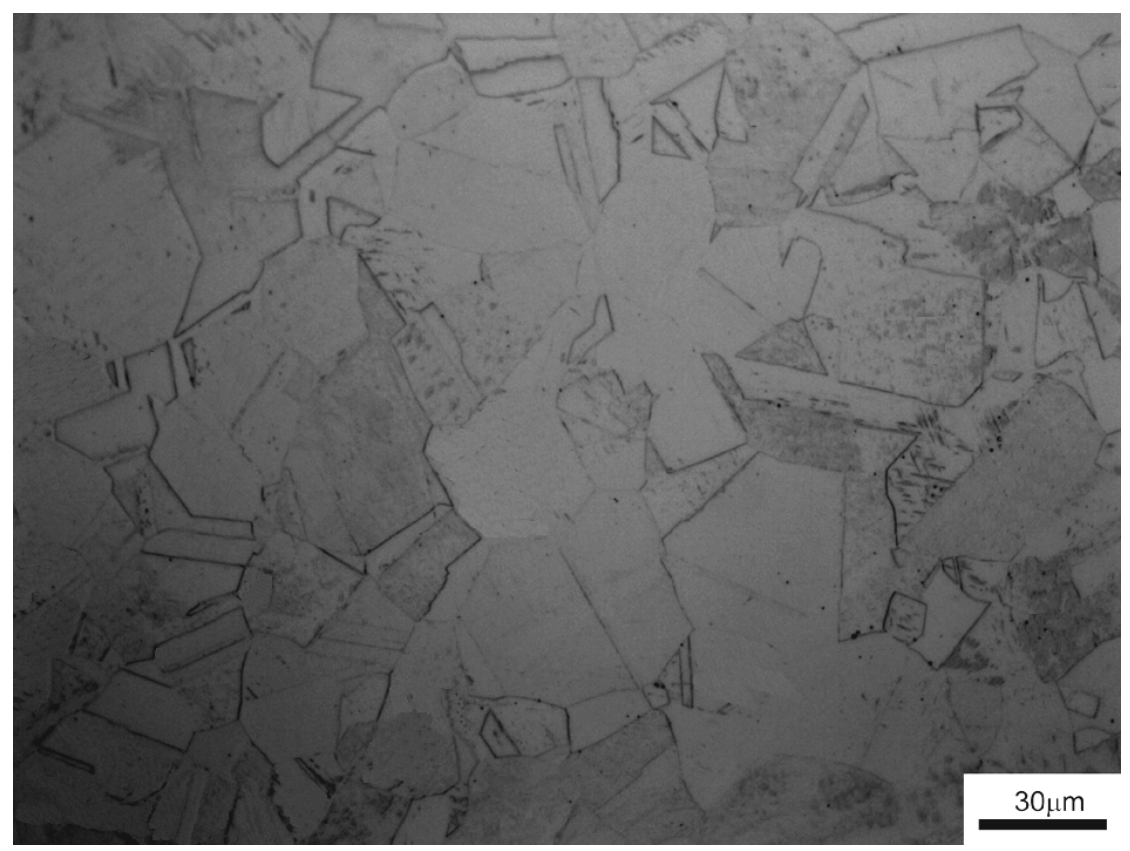

(a)

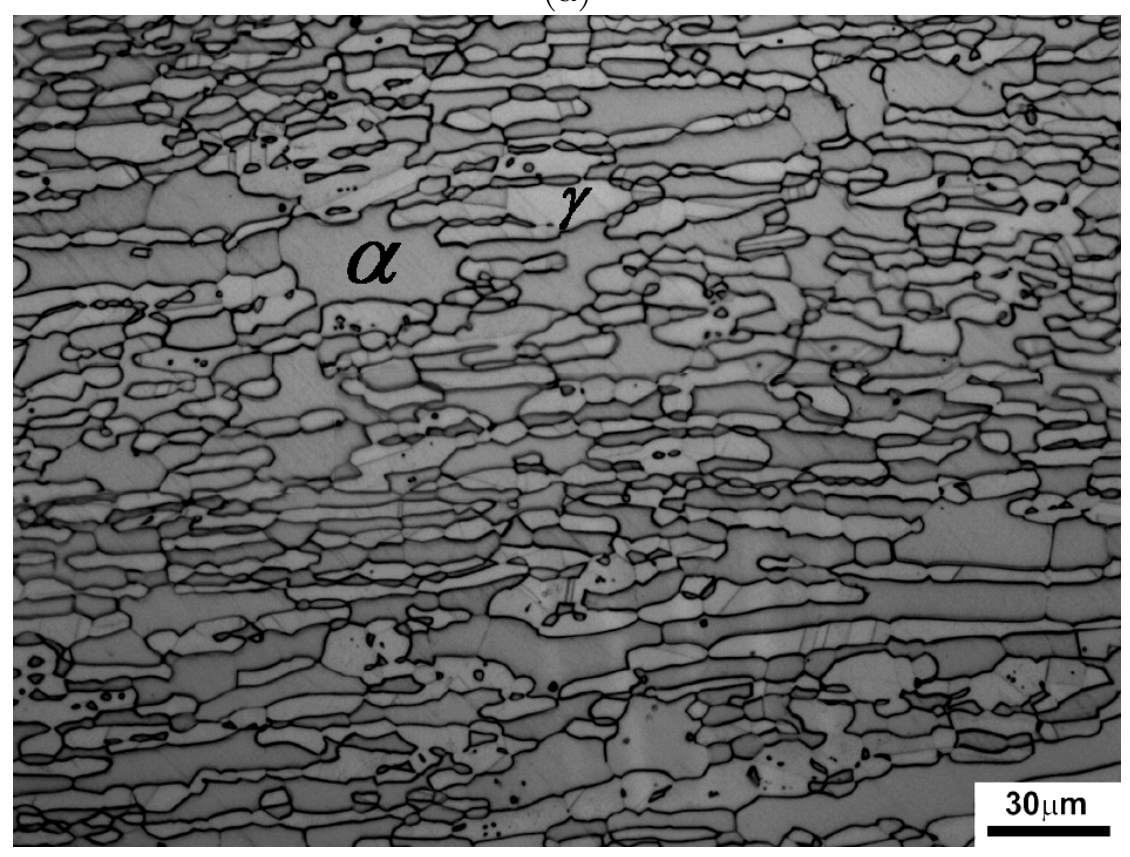

(b)

Figura 5.1: Micrografias ópticas dos materiais de estudo no estado como recebido, (a) aço inoxidável 304L mostrando grãos austeníticos e (b) aço inoxidável 318 mostrando grãos de austenita e ferrita. Ataque eletrolítico com ácido oxálico $10 \%$ em ambos os materiais.

ImageJ), deformados na direção de laminação. Para este material a dureza foi de aproximadamente $250 \pm 10 \mathrm{HV}$, medida com carga de 0,1 kgf. 


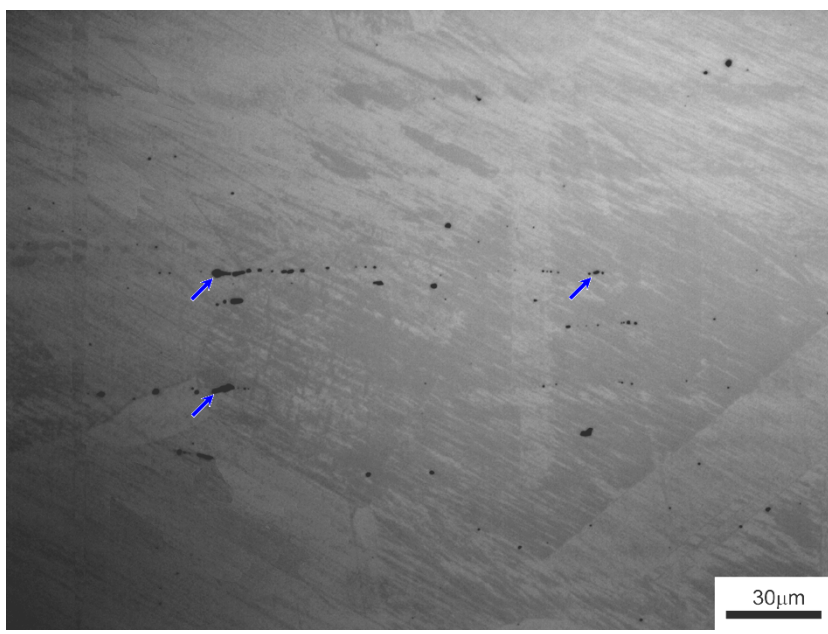

(a)

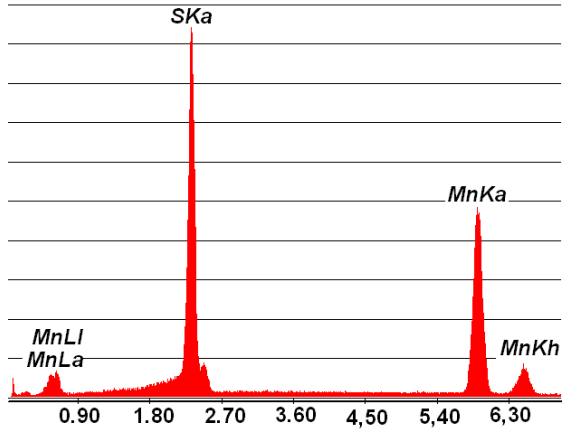

(b)

Figura 5.2: (a) micrografia óptica sem ataque do aço inoxidável 304L mostrando inclusões de sulfeto de manganês e (b) espectro EDS confirmado inclusões de sulfeto de manganês.

\subsubsection{Caracterização dos materiais de estudo antes dos ensaios de desgaste por EC}

Como já foi dito, neste trabalho os materiais foram divididos em 5 tipos em função da microestrutura obtida após terem sido submetidos a diferentes tratamentos térmicos, termoquímicos e termomecânicos, visando obter ligas com alto teor de nitrogênio, exceto nos materiais de comparação que não contêm esse elemento.

A seguir são apresentadas informações sobre as características microestruturais e de propriedades mecânicas de cada uma destes tipos.

\subsubsection{Aços inoxidáveis com estrutura completamente austenítica e solubilizados (tipo 1)}

Estado nitretado e solubilizado 318HTGN+Sol, amostra 1).

Na figura 5.3 é apresentada a micrografia ótica da seção transversal do aço 318HTGN+Sol nitretado sob atmosfera de nitrogênio gasoso utilizando uma pressão de gás N2 de 1 atm, por um tempo de 8 horas, à temperatura de 1200 ${ }^{\circ} \mathrm{C}$ e resfriamento final em água (têmpera direta). O elevado teor de nitrogênio introduzido durante a nitretação (0,9 \% em peso) promoveu total transformação do aço austeno-ferrítico em aço $100 \%$ austenítico. Após nitretação esse aço foi solubilizado a $1200{ }^{\circ} \mathrm{C}$ por 1 hora, apresentando microestrutura constituída por grãos equiaxiais. Nesta micrografia observa-se uma grande quantidade de maclas de recozimento, que se formam devido ao fato dos aços austeníticos apresentarem baixa energia de defeito de empilhamento. 


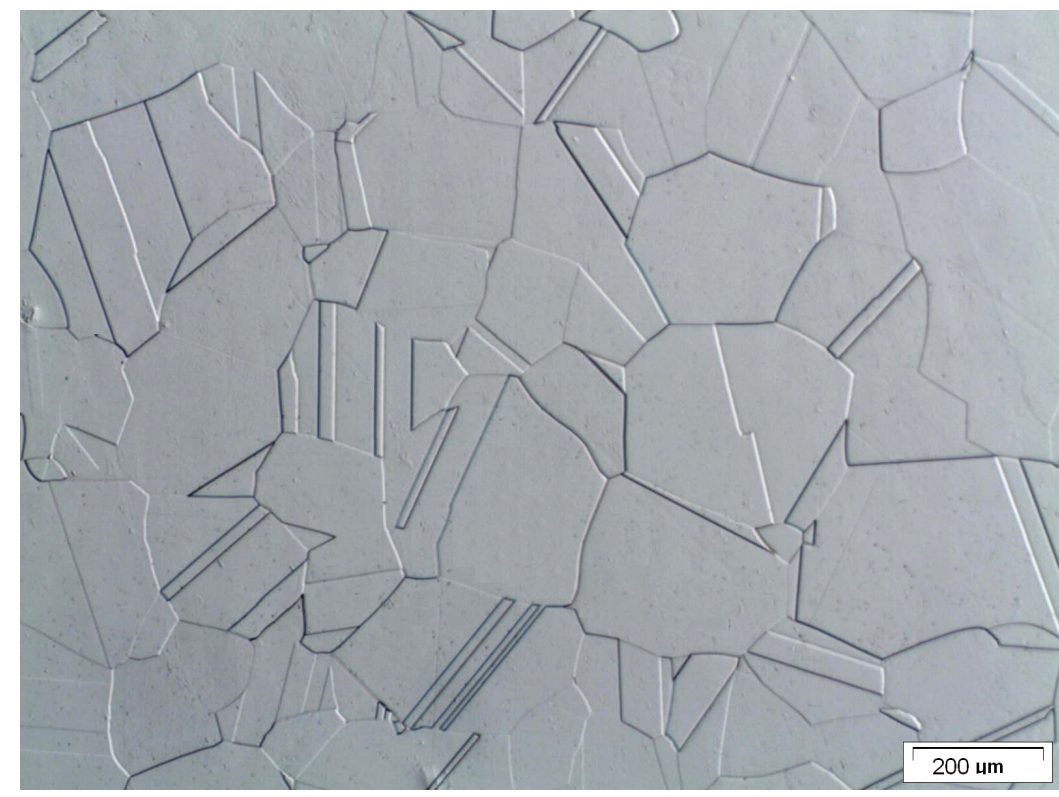

Figura 5.3: Microestrutura do aço inoxidável 318HTGN+Sol. Ataque eletrolítico com ácido oxálico $10 \%$.

Nesse estado o aço 318HTGN+Sol apresenta um tamanho de grão médio de $160 \pm 10 \mu m$ e uma dureza aproximada de $330 \pm 12 H V 0,1$. O teor de nitrogênio, após a nitretação, foi de aproximadamente $0,9 \pm 0,15 \%$ em massa, medido através da técnica WDS.

A figura 5.4 (a) apresenta o mapa de distribuição de orientações cristalográficas (OIM - Orientation Image Map) da superfície do material, no estado nitretado e solubilizado, obtido por difração de elétrons retro-espalhados. Na figura 5.4 (b) encontra-se a figura de pólo inversa (IPF - Inverse Pole Figure) do mapa apresentado na figura 5.4 (a) onde é possível observar se a amostra possui ou não forte textura com predominância de planos cristalográficos paralelos à superfície da amostra.

Do mapa de distribuição de orientações cristalográficas (OIM) mostrado na figura 5.4 (a), é possível verificar a obtenção de um material com uma forte orientação preferencial após o tratamento de nitretação, com acentuada população de grãos com planos 101 orientados paralelos à superfície das amostras como indicado pela predominância de cores verdes na figura 5.4 (a) e pela figura de pólo inversa (figura 5.4 (b). A orientação cristalográfica preferencial é atribuída à forma como é realizado o tratamento de nitretação gasosa em alta temperatura, que como relatado por Tschiptschin e Garzón (GARZÓN; TSCHIPTSCHIN, 2003). Durante o aquecimento sob vácuo do aço UNS S31803 forma-se ferrita. Ao final do ciclo de aquecimento ocorre crescimento seletivo dos grãos ferríticos o que gera uma microestrutura grosseira com uma textura acentuada. Após a exposição do 


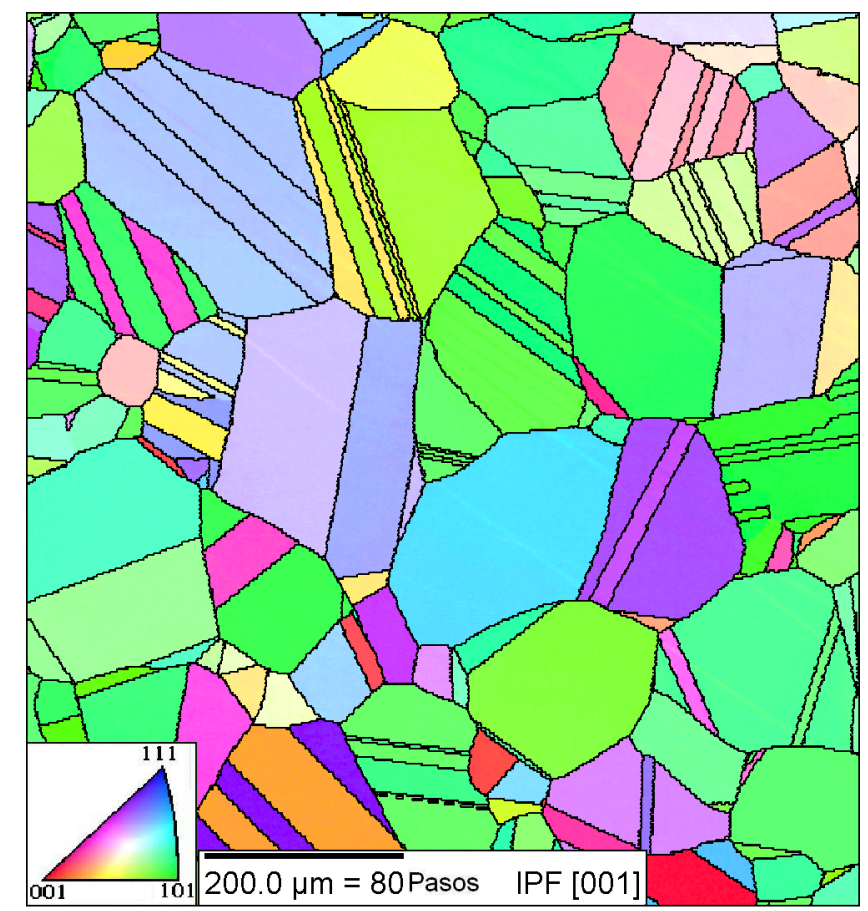

(a)

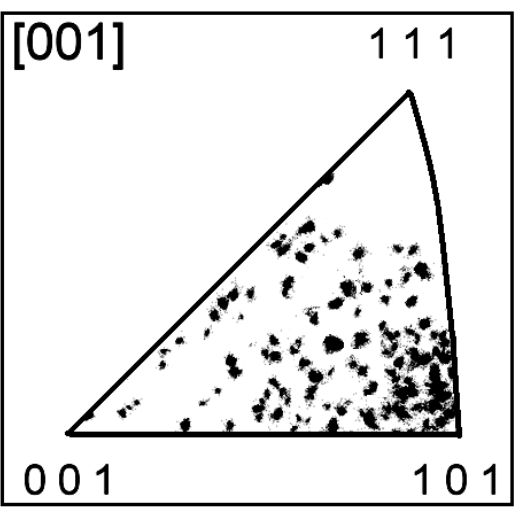

(b)

Figura 5.4: (a) mapa de distribuição de orientações cristalográficas (OIM) para o aço inoxidável 318HTGN+Sol obtido por EBSD, (b) Figura de pólo inversa IPF. [TSL/OIM]

material à atmosfera de nitrogênio, ocorre precipitação de austenita na forma de placas laterais que mantém relações de orientação de Kudjumov-Sachs com os grãos ferríticos com 24 variantes, dai a textura presente neste aço.

Estado nitretado, laminado (30 \%) e solubilizado (318HTGN+Lam+Sol, amostra 2). Na figura 5.5 é apresentada a micrografia da superfície do aço inoxidável 318 na condição nitretado a $1200{ }^{\circ} \mathrm{C}$, por 8 horas sob pressão de nitrogênio de $1 \mathrm{~atm}$, laminado a frio $30 \%$ e solubilizado a $1200{ }^{\circ} \mathrm{C}$ por 1 hora.

Na micrografia da figura 5.5 verifica-se que o tamanho de grão, após deformação por laminação, ficou com um tamanho de grão médio de diâmetro $120 \pm 10 \mu \mathrm{m}$. Observa-se também que a recristalização foi completa, pois todos os grãos apresentam morfologia equiaxial, A dureza também ficou parecida com a do material nitretado e solubilizado, isto é, $330 \pm 3 \mathrm{HV}$.

A figura 5.6 (a) apresenta os resultados de medidas de textura pela técnica de difração de elétrons retroespalhados (EBSD) da superfície do aço 318HTGN+Lam+Sol.

Na figura 5.6 (a) é apresentado o mapa OIM da distribuição de orientações cristalográficas. Nesse mapa se verifica que o material apresenta uma 


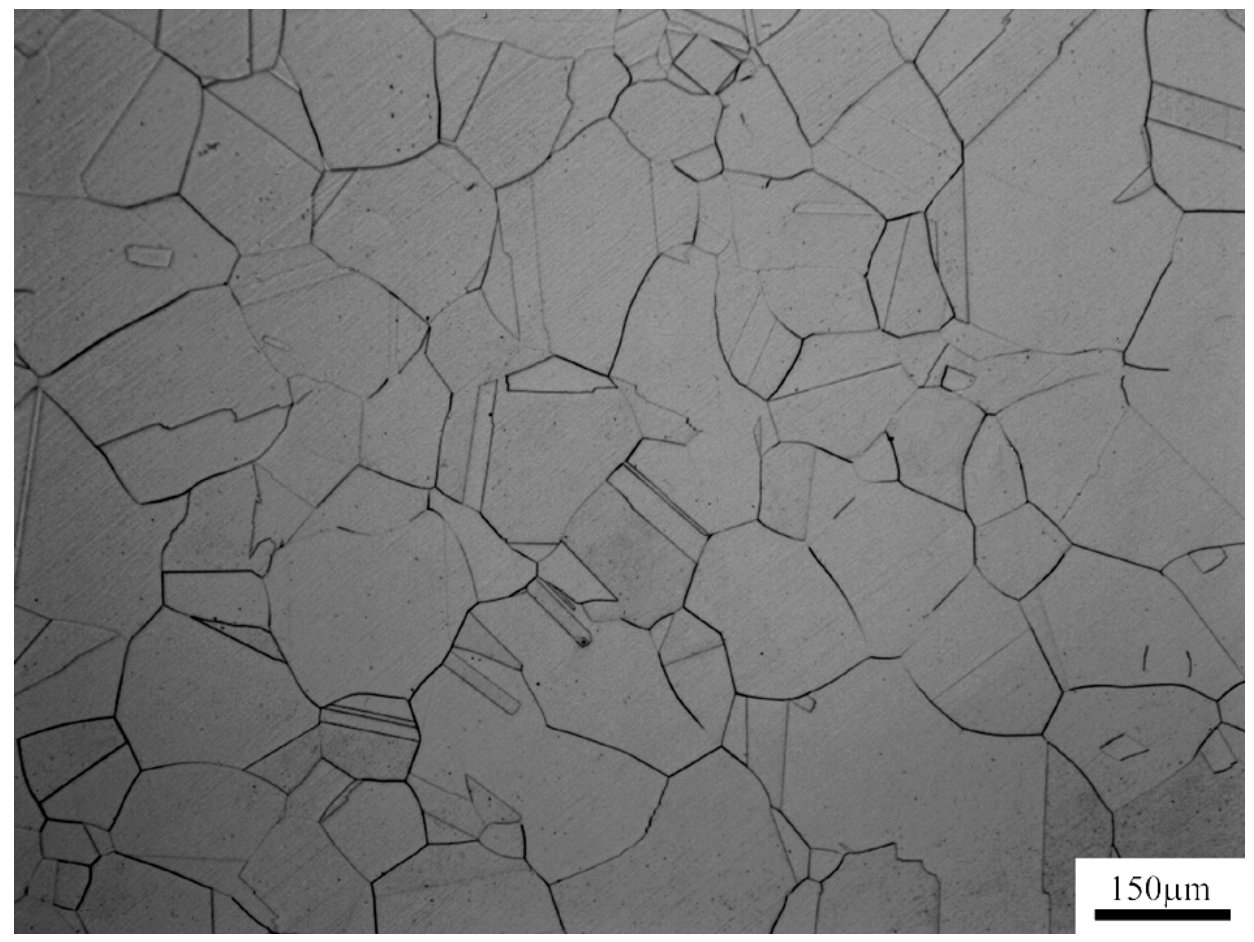

Figura 5.5: Micrografia da superfície do aço inoxidável 318HTGN+Lam+Sol. Ataque eletrolítico com ácido oxálico $10 \%$.

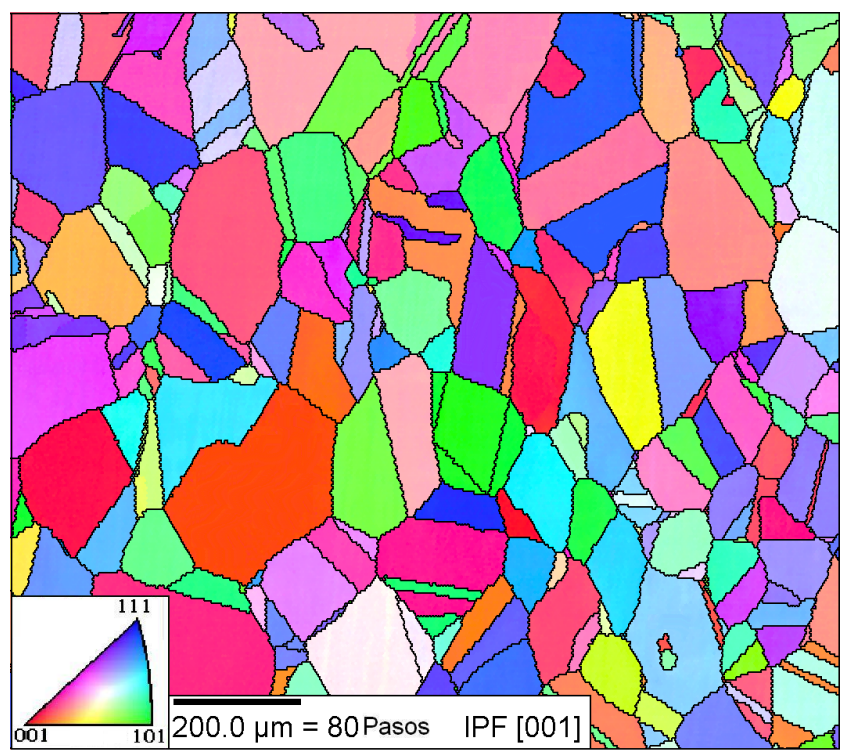

(a)

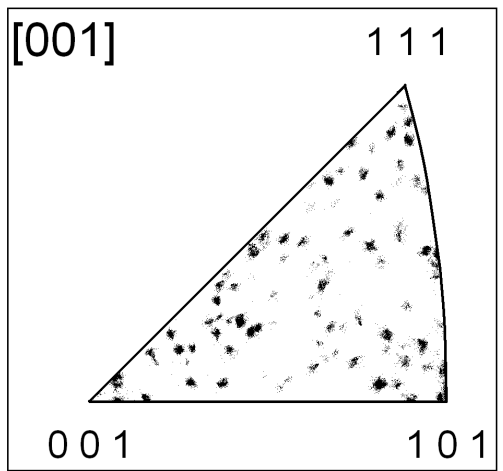

(b)

Figura 5.6: (a) mapa de distribuição de orientações cristalográficas para o aço inoxidável 318HTGN+Lam+Sol obtido por EBSD, (b) Figura de pólo inversa IPF.

distribuição de orientações que pode ser considerada aleatória, produto da laminação e subsequente recristalização durante o tratamento de solubilização. Essa aleatoriedade de orientações pode ser verificada na figura de pólos inversa mostrada na figura 5.6 (b), onde é possível notar que os pontos estão uniformemente distribuídos na área do triângulo, indicando que não há orientações preferenciais quando o aço 318 nitretado em alta temperatura é em 
seguida deformado a frio e recristalizado.

\subsubsection{Aços inoxidáveis com estrutura completamente austenítica e encruados (tipo 2)}

Estado nitretado e laminado (30\%) ( 318HTGN+Enc, amostra 3).

Na figura 5.7 é apresentada uma micrografia da superfície do aço inoxidável 318 na condição de nitretado a $1200{ }^{\circ} \mathrm{C}$, por um tempo de 8 horas e uma pressão de nitrogênio de 1 atm e posteriormente laminado a frio (encruado), até atingir $30 \%$ de redução da espessura.

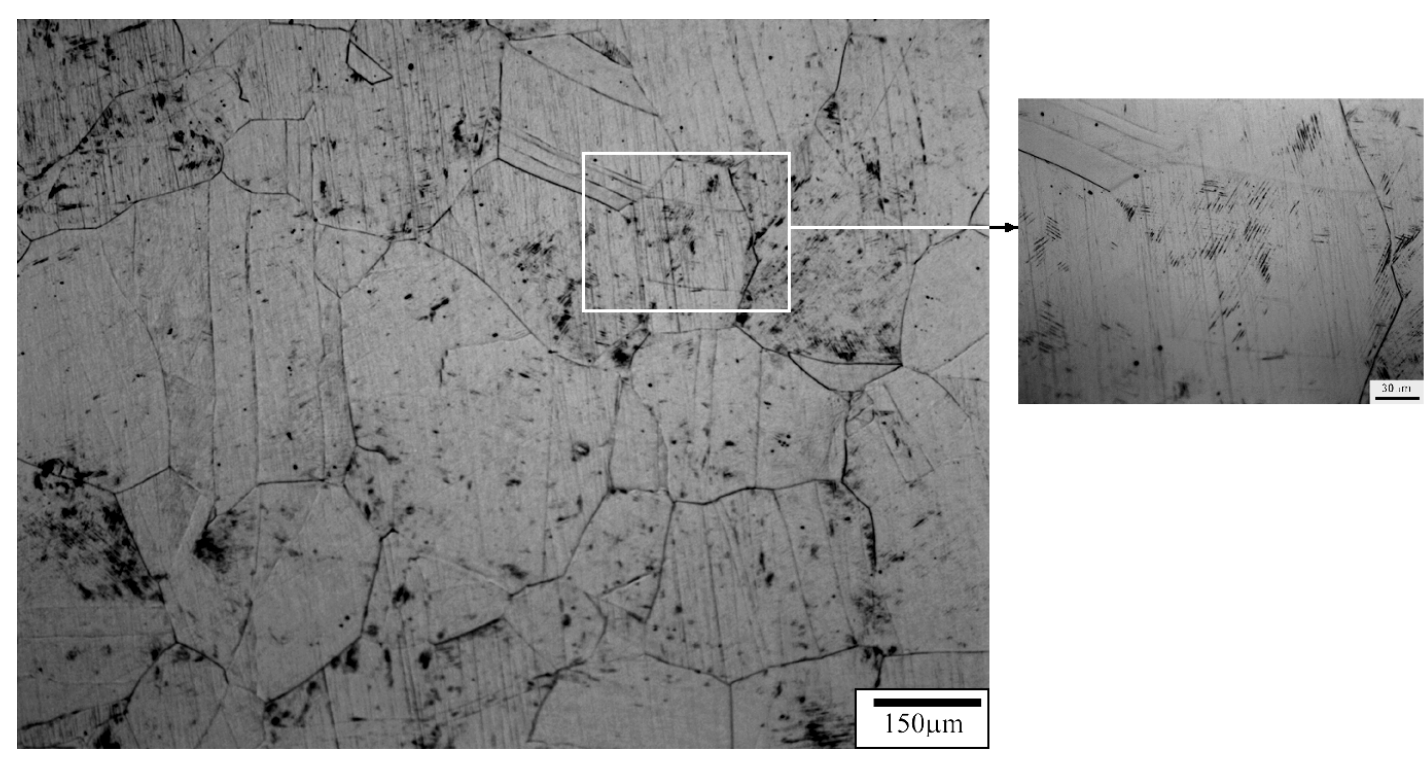

Figura 5.7: Microestrutura da superfície do aço 318HTGN+Enc mostrando grãos deformados contendo bandas de cisalhamento grosseiras. Ataque eletrolítico com ácido oxálico $10 \%$..

No detalhe à direita da micrografia da figura 5.7 é possível notar bandas de cisalhamento dentro de alguns grãos, formadas durante o processo de laminação. A formação dessas bandas deixa em evidência que o processo de deformação foi mais acentuado em alguns grãos do que em outros. Observa-se também que a equiaxialidade dos grãos foi mantida após o processo de laminação, embora a curvatura dos contornos de grão, e especificamente os contornos de macla, tenha mudado levemente. A dureza do material neste estado foi de aproximadamente $470 \pm 14 H V 0,01$ e o tamanho de grão foi de $120 \pm 10$ mum 


\subsubsection{Aços inoxidáveis com estrutura austenítica contendo dispersão de nitretos (tipo 3)}

Estado nitretado com estrutura austenítica e nitretos dispersos (318HTGN+Nit, amostra 4) livre de encruamento. Na figura 5.8 é apresentada a micrografia da superfície do aço inoxidável 318 na condição de nitretado a $1070{ }^{\circ} \mathrm{C}$, por um tempo de 3 horas e uma pressão de nitrogênio de 2 atm, condições que permitiram a obtenção de uma estrutura austenítica com presença de nitretos de cromo. Essa microestrutura foi obtida sob condições de pressão e temperatura (vide figura 4.2) segundo a condição (b) mostrada, em que se obteve uma estrutura composta por austenita com nitretos de cromo precipitados tanto nos contornos quanto no interior dos grãos.

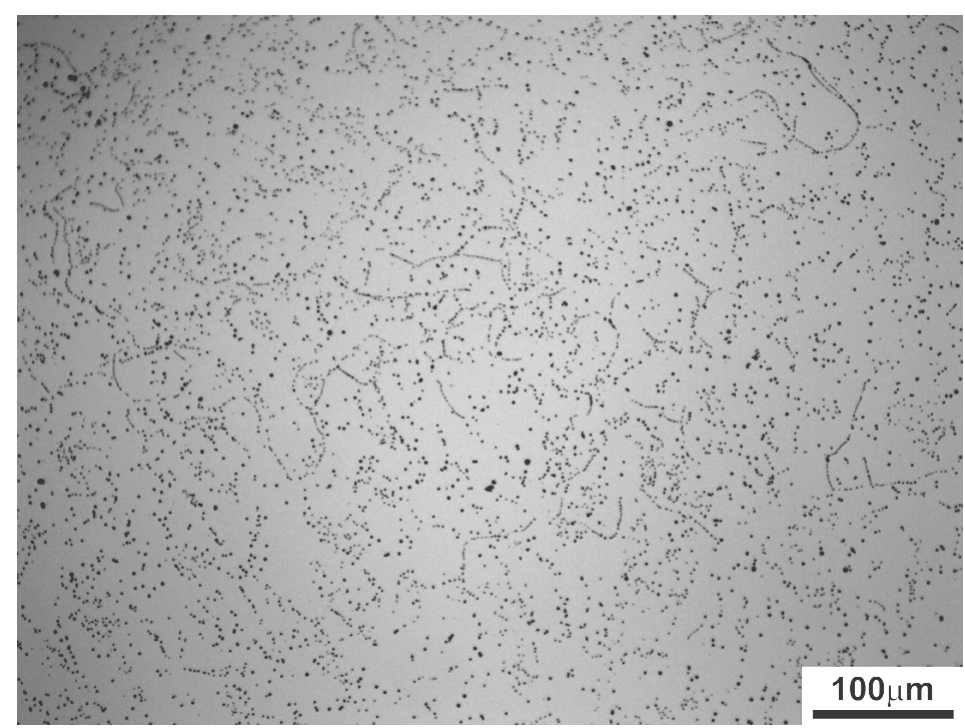

(a)

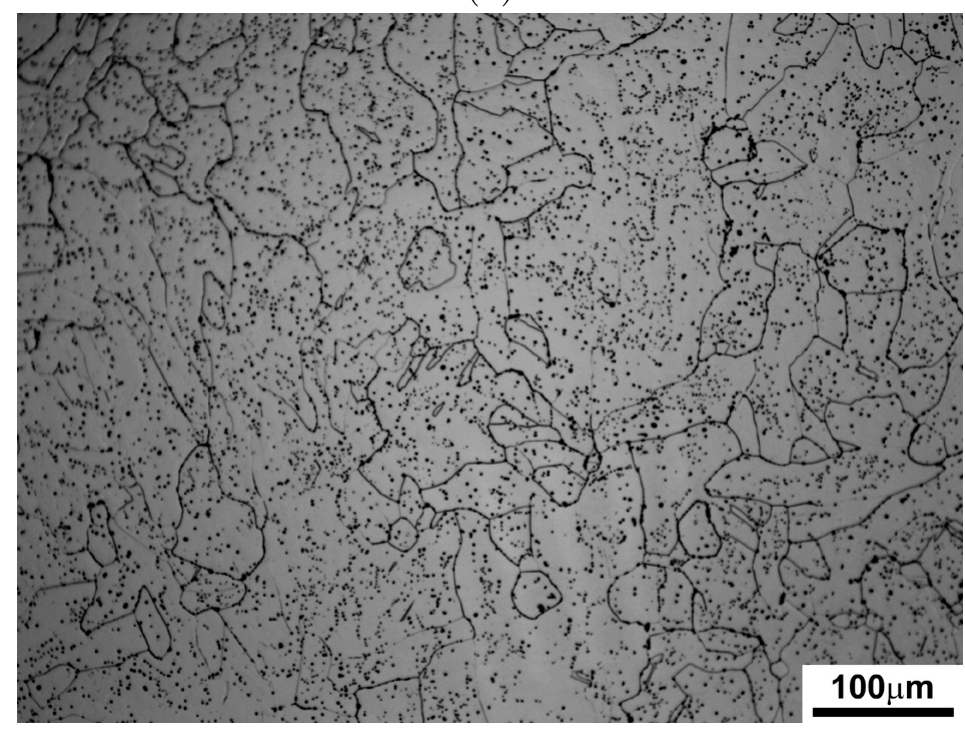

(b)

Figura 5.8: Microestruturas da superfície do aço 318HTGN+Nit: (a) sem ataque, b) atacado eletrolíticamente com ácido oxálico $10 \%$. 
Nas micrografias da figura 5.8 (a) e (b) observa-se uma estrutura de grãos equiaxiais em sua grande maioria, com um tamanho médio de $85 \pm 6 \mu \mathrm{m}$. A dureza do material neste estado é de aproximadamente $340 \pm 12 \mathrm{HV}$.

$\mathrm{Na}$ figura 5.9 se apresenta o mapa de distribuição de orientações cristalográficas OIM da superfície do material, no estado nitretado a gás com presença de nitretos de cromo.

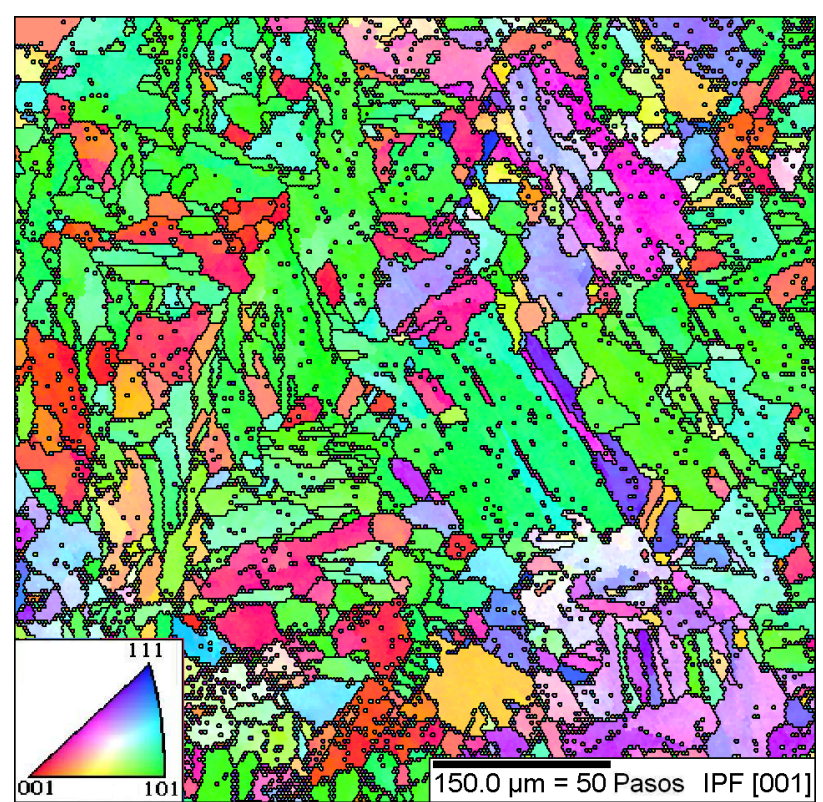

(a)

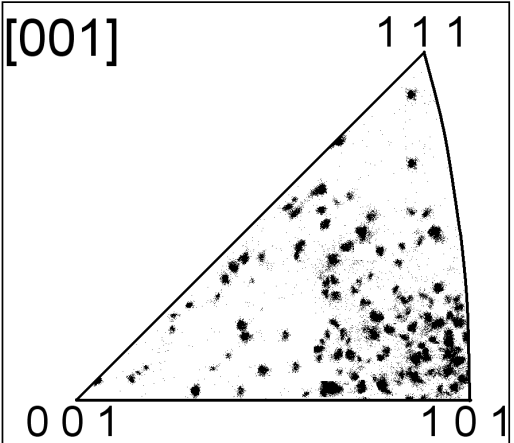

(b)

Figura 5.9: Para o aço 318HTGN+Nit: (a) mapa de distribuição de orientações cristalográficas, (b) IPF.

Do mapa (OIM) da figura 5.9 (a) observa-se uma estrutura composta por grãos alongados de austenita, apresentando uma distribuição homogênea de nitretos, localizados tanto no interior dos grãos quanto ao longo de seus contornos. Do mapa (OIM) é possível notar também que o material apresenta orientação preferencial dos grãos com os planos do tipo (101) paralelos à superfície das amostras, como verificado na IPF apresentada na figura 5.9 (b).

\subsubsection{Aços inoxidáveis com estrutura de austenita expandida (tipo 4)}

Aço 318 nitretado a gás + nitretado a plasma (318HTGN+Plas, amostra 5). Nas figuras 5.10 (a) a (c) são apresentadas micrografias do aço 318 HTGN+Sol nitretado a gás a $1200{ }^{\circ} \mathrm{C}$, por um tempo de $3 \mathrm{~h}$ e uma pressão de nitrogênio de 1 atm, e depois nitretado a plasma a uma temperatura de 400 ${ }^{\circ} \mathrm{C}$ em atmosfera de $75 \% \mathrm{~N}_{2}: 25 \% \mathrm{H}_{2}$ por um tempo de 12 horas.

Da sequência de micrografias apresentadas na figura 5.10 é possível observar 


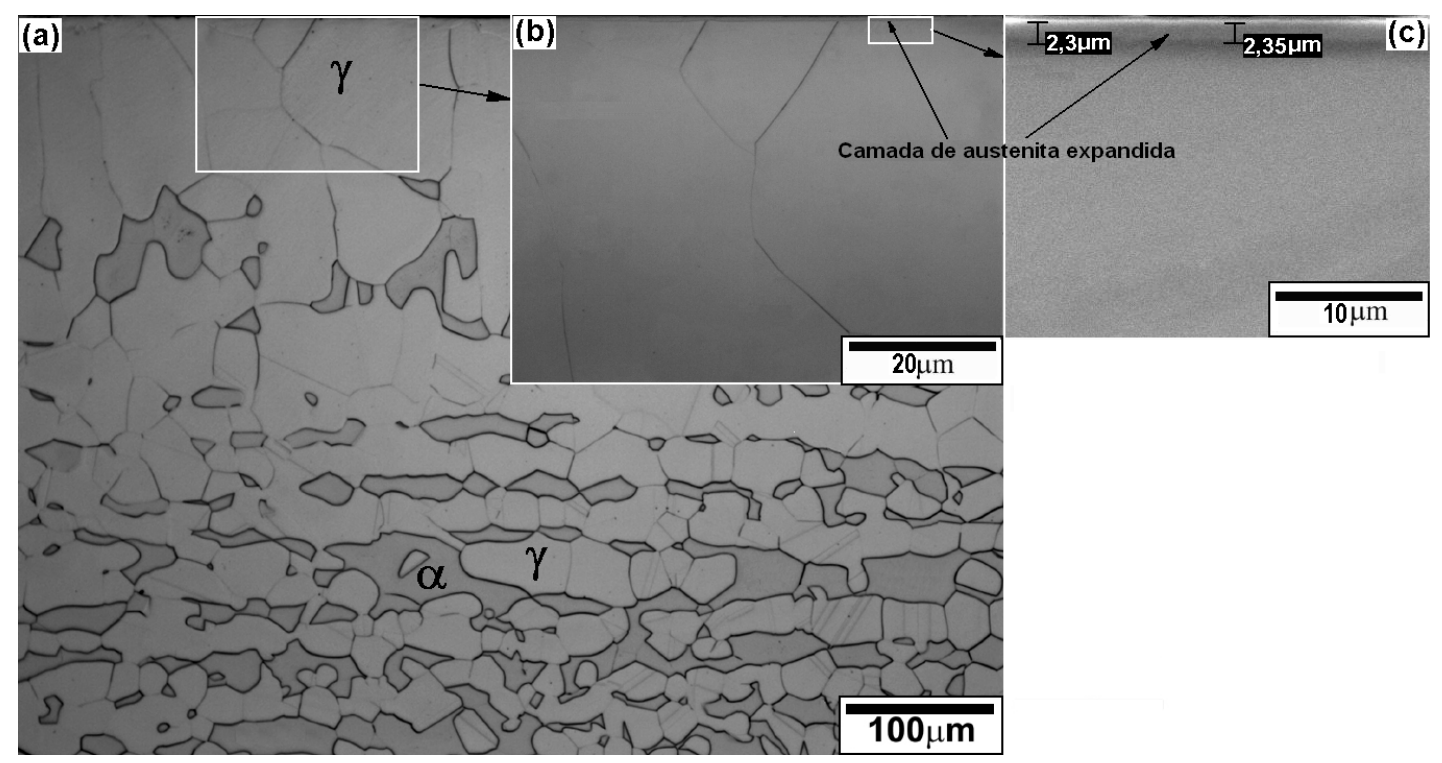

Figura 5.10: Microestrutura da seção transversal do aço 318HTGN+Plas. (a) microestrutura com núcleo dúplex de austenita e ferrita e superfície de austenita, (b) camada grossa de austenita obtida por nitretação gasosa, e (c) camada fina de austenita expandida obtida por nitretação a plasma. Ataque eletrolítico com ácido oxálico $10 \%$.

que com a nitretação gasosa realizada por um tempo de 3 horas, obteve-se uma microestrutura formada por um núcleo bifásico de austenita e ferrita (figura 5.10 (a)), seguida por uma camada de austenita com um teor de nitrogênio em solução sólida de aproximadamente 0,9\% e uma espessura de aproximadamente $100 \mu \mathrm{m}$ (figura 5.10 (b)), e terminando na borda superior com uma fina camada de austenita expandida com espessura aproximada de 2,3 4 m (figura 5.10 (c)). O tamanho de grão da austenita expandida tem correspondência com aquele da camada de austenita obtida por nitretação gasosa que é de $150 \pm 10 \mu \mathrm{m}$. A dureza desta camada foi de $1700 H V 0,005$.

Na figura 5.11 se apresenta o mapa de distribuição de orientações cristalográficas OIM da superfície do aço 318HTGN+Plas.

Do mapa (OIM) da figura 5.11 pode-se observar que a camada de austenita expandida formada na superfície do material previamente nitretado a gás, conserva a orientação preferencial dos grãos com planos do tipo 101 orientados paralelos à superfície das amostras, como pode ser verificado no mapa de orientações da figura 5.11 (a) e da figura de pólo invesa mostrada na figura 5.11 (b). Nota-se também que os grãos são do tipo equiaxiais completamente austeníticos, contendo também, maclas de recozimento.

Aço 304L solubilizado e nitretado a plasma (304LSol+Plas, amostra

6). Na figura 5.12 são apresentadas micrografias do aço 304L nos estados (a) 


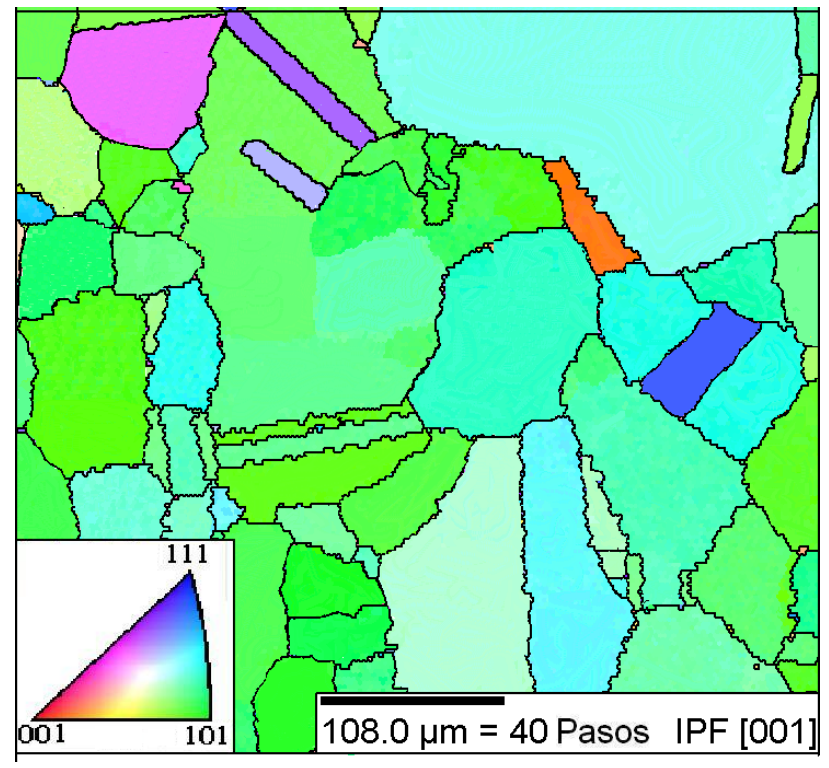

(a)

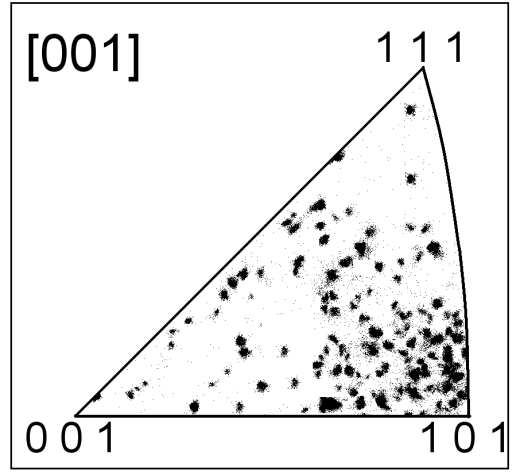

(b)

Figura 5.11: Mapa de distribuição de orientações cristalográficas OIM da superfície do aço inoxidável 318HTGN+Plas (b) IPF

solubilizado e (b) nitretado a plasma.

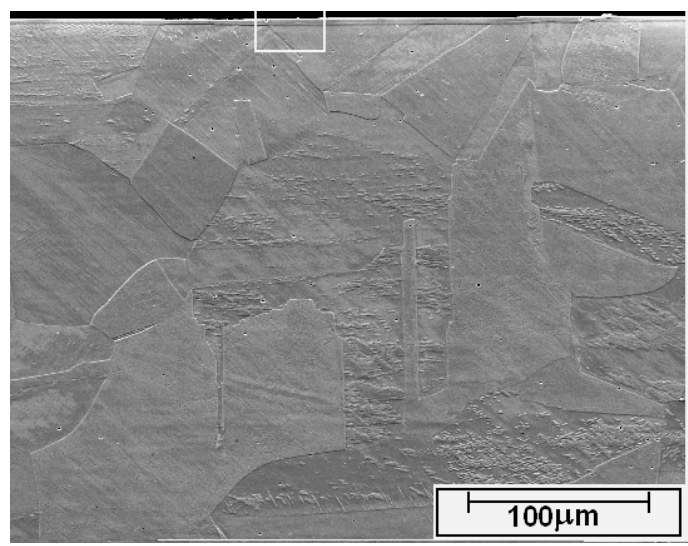

(a)

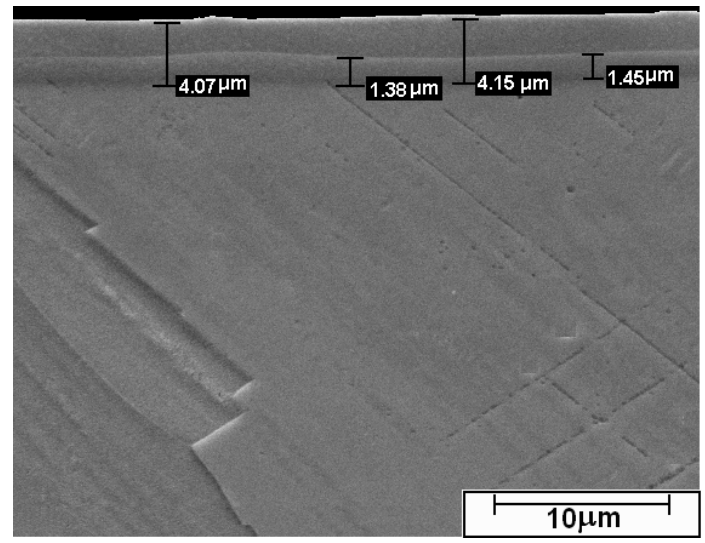

(b)

Figura 5.12: Para o aço 304LSol+Plas: (a) micrografia com pequenos aumentos após nitretação a plasma, (b) detalhe da região destacada em (a) mostrando a fina camada superficial de austenita expandida. Ataque eletrolítico com ácido oxálico $10 \%$.

Na figura 5.12 (b), observa-se que com o tratamento de nitretação a plasma formou-se uma fina camada de austenita expandida (aproximadamente $4 \mu \mathrm{m}$ de espessura) na superfície do aço 304LSol previamente solubilizado. A dureza desta camada é de aproximadamente 1500 HV0,005. O acúmulo de carbono empurrado pelo nitrogênio que está entrando via difusão nessa região, é uma das hipóteses que se têm para explicar a formação de uma segunda camada rica em carbono com cerca de 1,5 $\mathrm{m}$ de espessura. As duas camadas de alta dureza formaram-se 
sobre um substrato mole de aproximadamente $180 \pm 10 H V 0,1$

\subsubsection{Materiais de comparação (tipo 5)}

Aço 304L solubilizado (304LSol, amostra 7). Na figura 5.13 é apresentada a micrografia do aço inoxidável 304L no estado solubilizado.

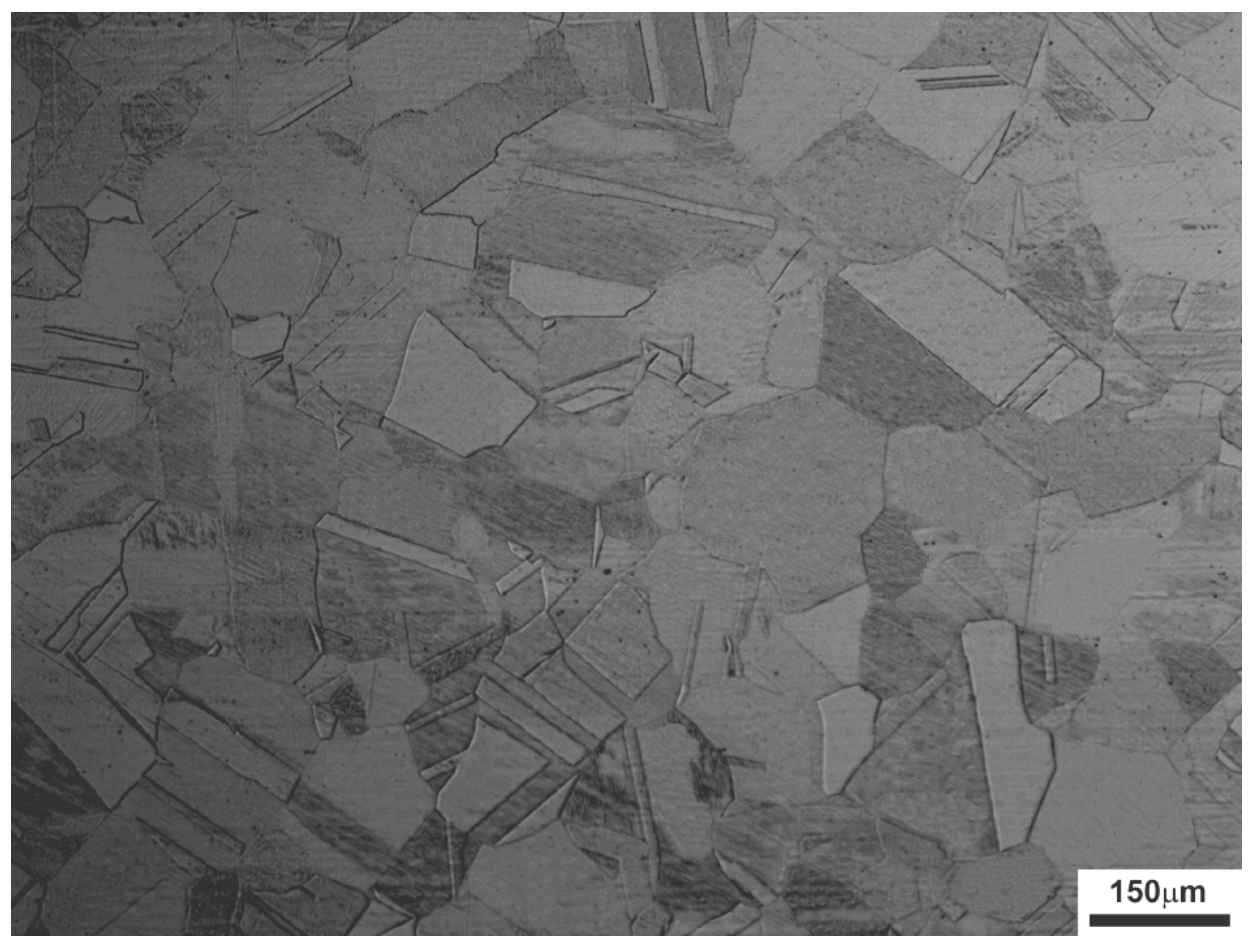

Figura 5.13: Microestrutura do aço inoxidável 304LSol. Ataque eletrolítico com ácido oxálico $10 \%$.

Na figura 5.13 se vê que o tratamento de solubilização realizado neste aço permitiu a obtenção de uma estrutura de grãos equiaxiais, com tamanho médio de $120 \pm 10 \mu \mathrm{m}$ e uma dureza de $180 \pm 10$ HV0,1 .

A figura 5.14 (a) apresenta o mapa de distribuição de orientações cristalográficas OIM da superfície do material, no estado solubilizado.

Do mapa OIM apresentado na figura 5.14 (a) observa-se que o aço 304LSol apresenta orientação cristalográfica aleatória, como confirmado pela figura de pólo inversa IPF mostrada na figura 5.14 (b)

\section{Superliga de cobalto "Stellite-6"(amostra 8). A figura 5.15} apresenta a micrografia da superliga de cobalto Stellite-6 no estado como recebida (bruta de fundição).

A micrografia da figura 5.15 mostra que a liga Stellite-6 é hipoeutética com estrutura composta por dendritas de Co e uma rede de carbonetos de Cr eutéticos 


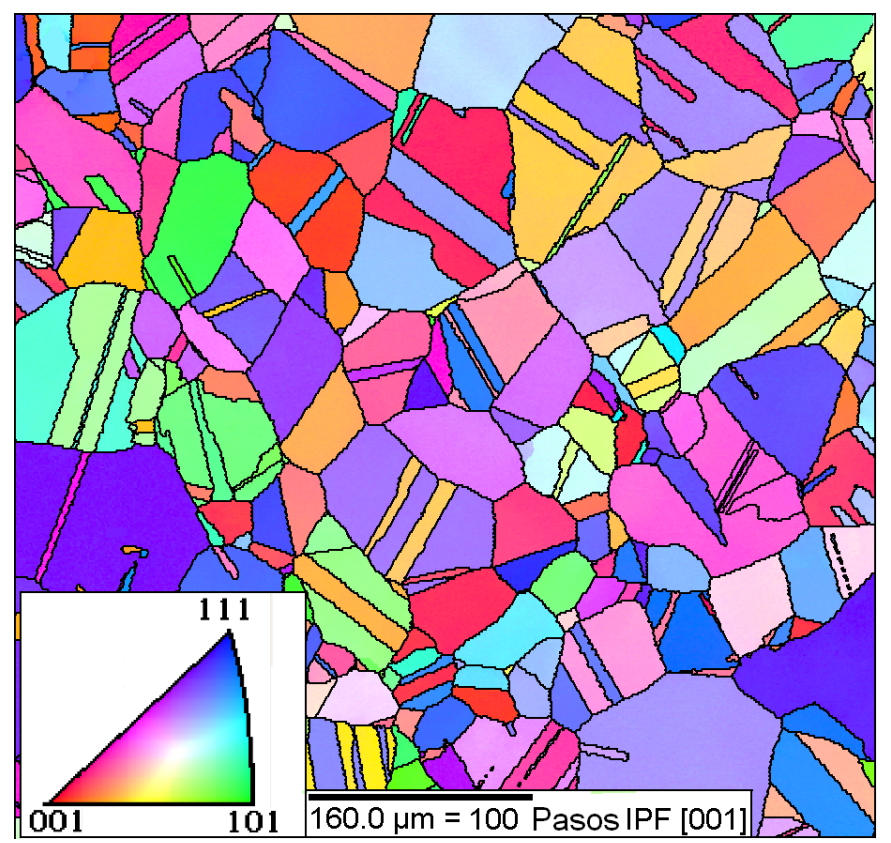

(a)

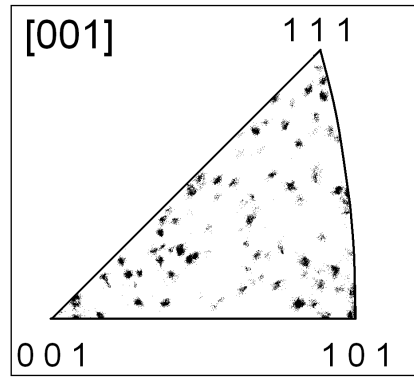

(b)

Figura 5.14: Mapa de distribuição de orientações cristalográficas OIM da superfície do aço inoxidável 304LSol, (b) IPF.

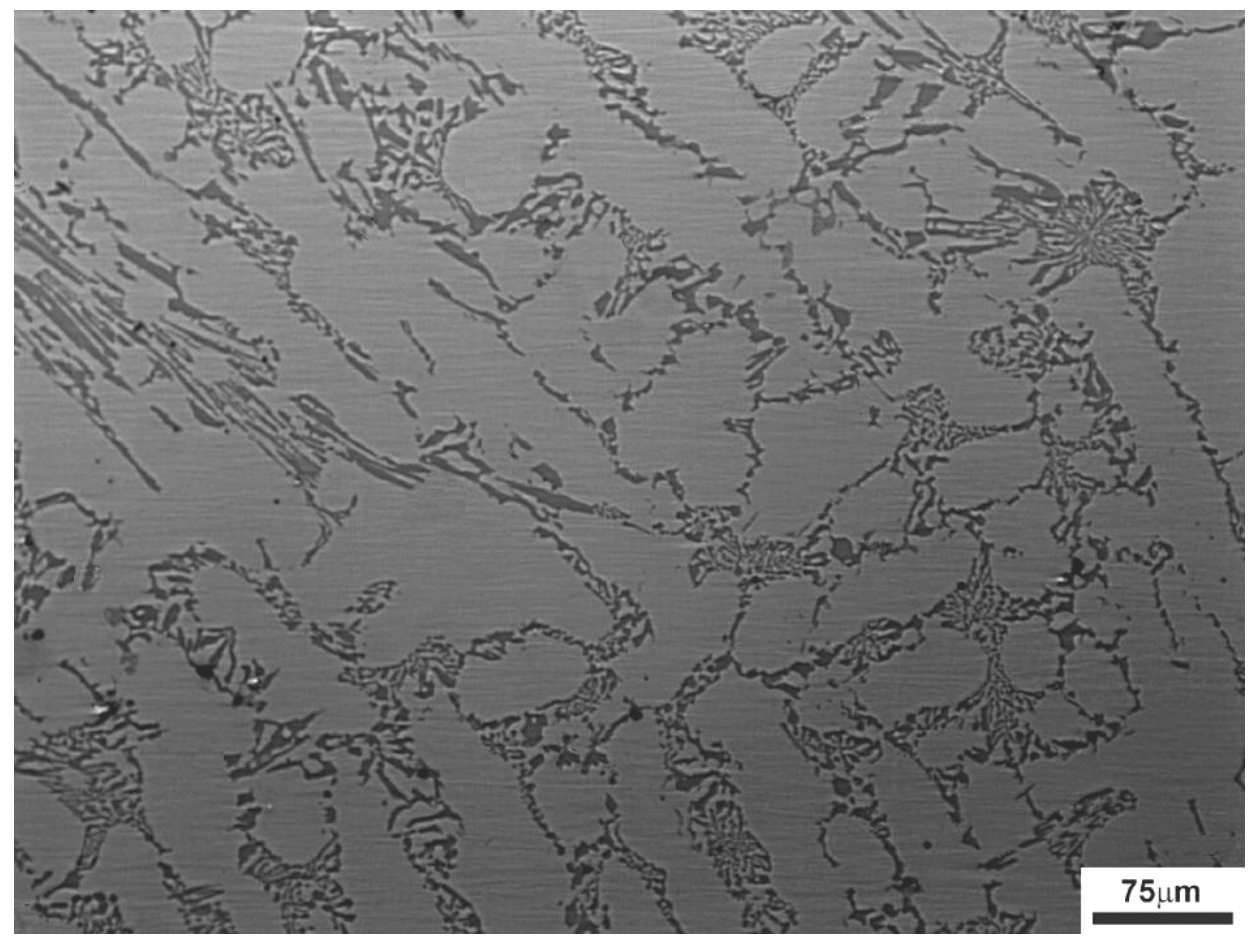

Figura 5.15: Microestrutura da superliga de cobalto Stellite-6 no estado como recebida (bruta de fundição). Amostra sem ataque.

com morfologia irregular. A dureza do material no estado como recebido (bruta de fundição) é de $660 \pm 10 H V 0,1$. 


\subsection{Análise dos mecanismos de desgaste por EC}

Os diferentes tipos de ligas apresentados e caracterizados no item anterior foram ensaiados em erosão cavitação. Na figura 5.16 são apresentados os gráficos de perda de massa em função do tempo de ensaio para os diferentes materiais.

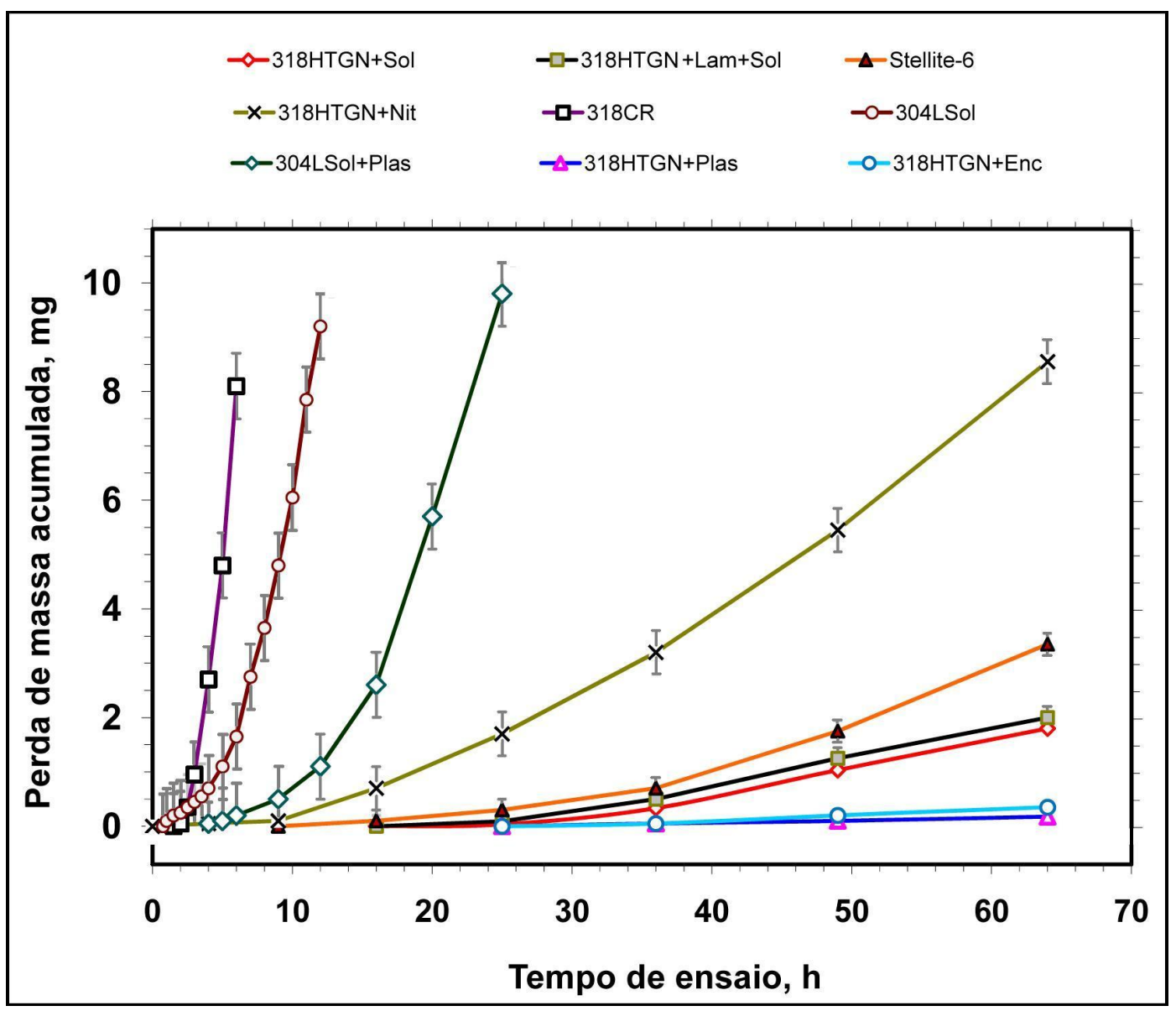

Figura 5.16: Perda de massa acumulada em função do tempo de ensaio em experimentos de desgaste EC.

Observando as diferentes curvas de perda de massa acumulada apresentadas na figura 5.16, verifica-se que, através dos tratamentos de nitretação gasosa e a plasma, realizados nos materiais de estudo 318 e 304L (exceto os de comparação), foi possível melhorar a resistência ao desgaste EC, medida como a relação entre a taxa máxima de desgaste, para cada tipo de amostra estudada, com relação a taxa máxima de desgaste do material de comparação. Os principais resultados obtidos foram: as amostras com precipitação de nitretos (318HTGN+Nit), apresentaram taxa de desgaste 6,9 vezes menor; as amostras com nitrogênio em solução solida e solubilizadas (318HTGH+Sol) e laminadas e solubilizadas $(318$ HTGN+Lam+Sol), apresentaram taxa de desgaste 26,8 e 25 vezes menor respectivamente; as amostras com nitrogênio em solução sólida e encruadas (318HTGN+Enc) apresentaram taxa de desgaste 145 vezes menor e as amostras 
com camada superficial de austenita expandida (obtidas por nitretação a plasma), (318HTGN+Plas e 304LSol+Plas) apresentaram taxa de desgaste 177 e 300 vezes menor respectivamente.

Na tabela 5.1 são apresentados valores do tempo de incubação ti, (h), a taxa máxima de desgaste $\mathrm{w}(\mathrm{mg} / \mathrm{h})$, assim como resistência ao desgaste EC relativa, calculada como a relação entre a taxa de desgaste máxima de todos os materiais de estudo, com relação à dos materiais de comparação 304LSol, 318CR e Stellite-6.

Tabela 5.1: Tempo de incubação (ti), taxa de desgaste (w) e resistência ao desgaste EC relativa $(\mathrm{mg} / \mathrm{h})$ para todos os materiais utilizados com relação aos materiais 304LSol, 318CR e Stellite-6.

\begin{tabular}{|c|c|c|c|c|c|}
\hline Material & ti & w & \multicolumn{3}{|c|}{ Variação da resistência ao des- } \\
& & & \multicolumn{2}{|c|}{ gaste EC com respeito a: } \\
& $(\mathrm{h})$ & $(\mathrm{mg} / \mathrm{h})$ & 304LSol & 318CR & Stellite-6 \\
\hline 318HTGN+Plas & 35 & 0,005 & 290 & 660 & 21,2 \\
\hline 318HTGN+Enc & 30 & 0,010 & 145 & 330 & 10,6 \\
\hline 318HTGN+Sol & 25 & 0,054 & 26,8 & 61,1 & 1,96 \\
\hline 318HTGN+Lam+Sol & 20 & 0,058 & 25,0 & 56,9 & 1,90 \\
\hline Stellite-6 & 10 & 0,106 & 13,7 & 31,1 & - \\
\hline 318 Nit & 8,0 & 0,210 & 6,90 & 15,7 & - \\
\hline 304LSol+Plas & 5,0 & 0,820 & 1,77 & 4,10 & - \\
\hline 318CR & 2,5 & 3,300 & - & - & - \\
\hline 304LSol & 1,5 & 1,450 & - & 1,60 & - \\
\hline
\end{tabular}

Dos dados apresentados na tabela 5.1, observa-se que os aços 318HGTN+plas e 318HGTN+Enc, tiveram o melhor comportamento frente ao desgaste por EC, seguidos pelos aços nitretados a gás sem encruamento 318HTGN+Sol e 318HTGN+Lam+Sol, que superaram em 61 e 57 vezes respectivamente, a taxa de desgaste do aço sem nitrogênio 318CR.

A seguir será apresentada uma descrição detalhada dos mecanismos de desgaste para cada um dos materiais utilizados neste estudo, tomando como base a análise microestrutural observada nas diferentes micrografias, dos dados apresentados na figura 5.16 e na tabela 5.1, além dos mapas obtidos por EBSD quando for necessário.

\subsubsection{Aços inoxidáveis com estrutura completamente austenítica e solubilizados (tipo 1)}

\subsubsection{Aço 318 nitretado e solubilizado 318HTGN+Sol (amostra 1)}

A micrografia apresentada na figura 5.17, para o aço 318HTGN+Sol ensaiado por 4 horas em EC, mostra que, de modo geral, o dano nas primeiras etapas do 
desgaste não foi homogêneo na superfície; observam-se grãos e contornos de grão que se apresentam mais conservados (grãos mais escuros) do que outros que se apresentam mais claros, contendo no seu interior sinais de desgaste como bandas de escorregamento, protuberâncias, pites e outros defeitos. Na micrografia da figura 5.18 são mostrados detalhes ampliados onde se evidencia que o início da deterioração, devido ao desgaste por EC, se apresenta em alguns contornos de grão e bandas de deslizamento.

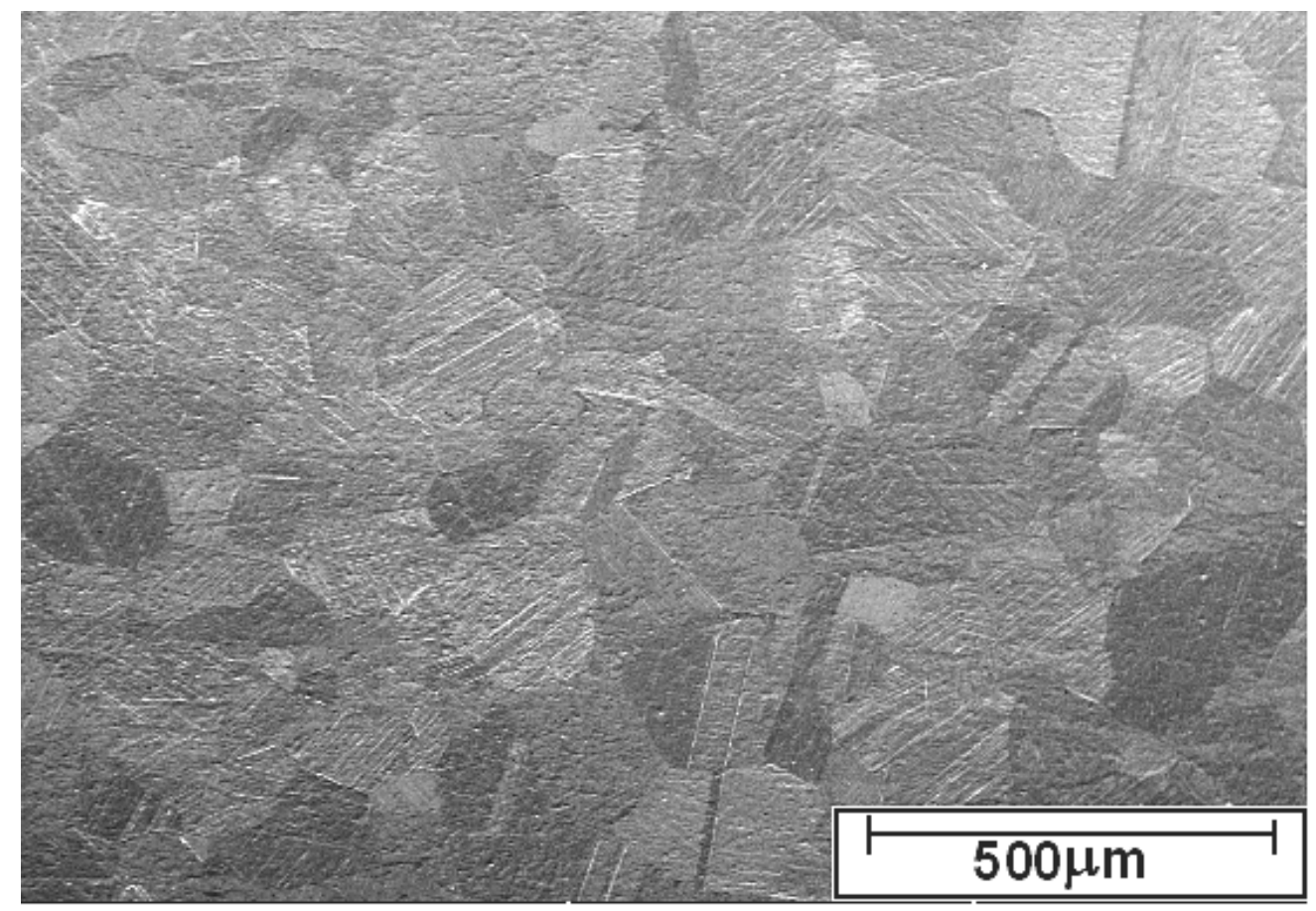

Figura 5.17: Micrografia MEV geral da superfície cavitada por 4 horas para o aço 318 HTGN+Sol.

Nas micrografias (a), (b) e (c) em detalhe apresentadas na figura 5.18 observa-se que durante o período de incubação do desgaste por EC ocorre intensa deformação plástica, evidenciada pela presença de bandas de deslizamento e protuberâncias no interior dos grãos. Esses defeitos superficiais produzem alterações da rugosidade além da formação de pequenos pites na superfície, como pode ser observado no detalhe da figura 5.18 (a). Observa-se também nas micrografias (b) e (c), que contornos de grão e bandas de deslizamento são sítios preferenciais para início do dano, e que a intensidade da deformação é altamente heterogênea, onde grãos vizinhos podem apresentar intensidades de deformação plástica marcadamente diferentes.

Em etapas posteriores do dano por EC, a propagação de trincas provoca fratura do material na forma de partículas de desgaste conhecidos como debris.

Nas figuras 5.19 (a) a (d) é apresentado o avanço do processo de desgaste por EC para 4, 9, 16, 25, 36 e 64 horas de ensaio, abrangendo etapas desde o período 


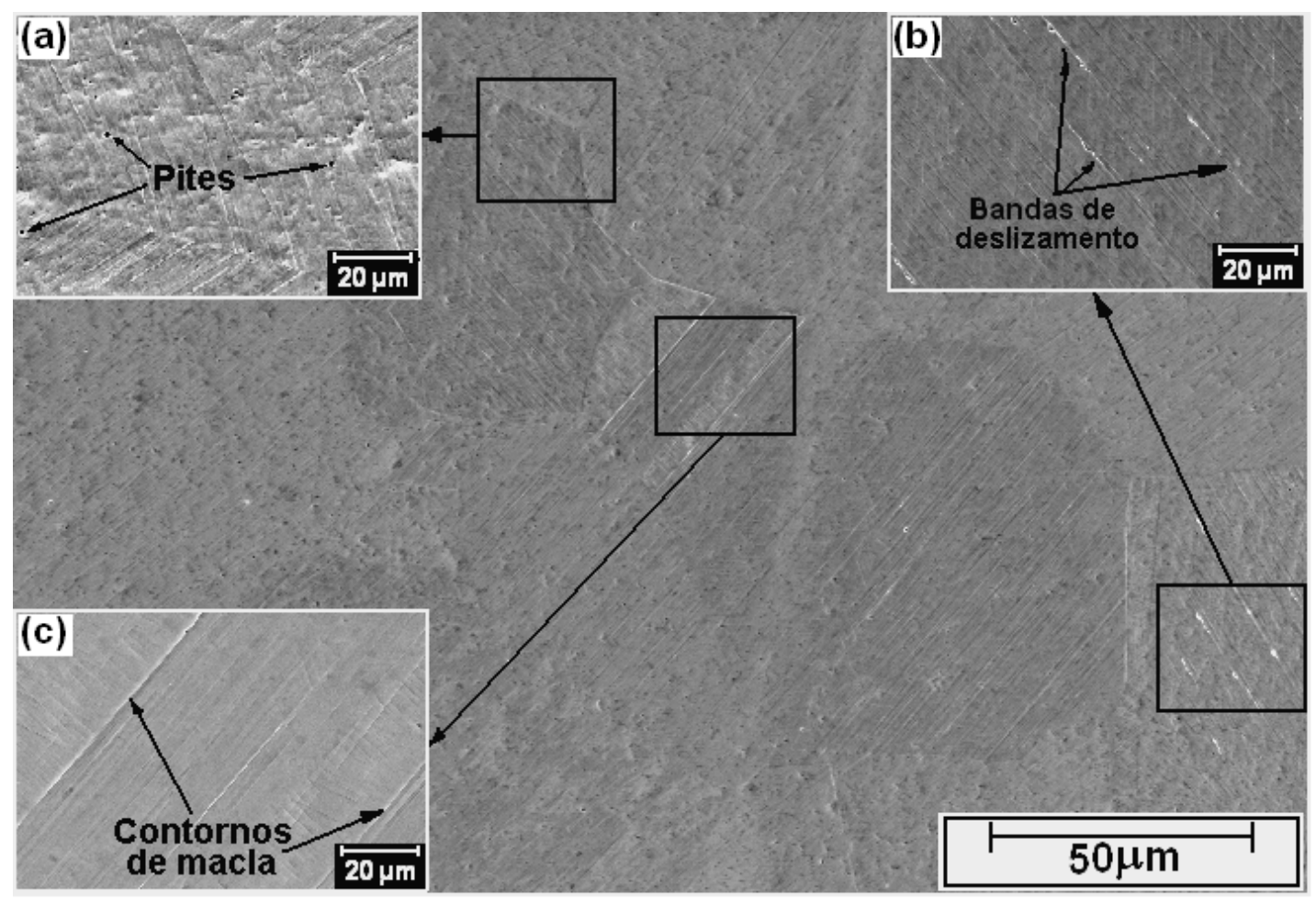

Figura 5.18: Micrografias MEV para 4 horas de ensaio de desgaste EC mostrando as regiões de inicio de dano durante o período de incubação do dano para o aço 318HTGN+Sol.

de incubação até etapas avançadas de desgaste.

Da sequência de micrografias da figura 5.19 observa-se que o dano inicia preferencialmente em contornos de grão e em algumas bandas de deslizamento (figuras 5.19 (a) e (b)) e que o principal mecanismo de desgaste operante é a deformação plástica, trazendo como consequência uma mudança da rugosidade superficial, favorecendo o aparecimento de defeitos como pites, protuberâncias e degraus de escorregamento. A partir de 16 horas de EC as bandas de escorregamento, localizadas no interior dos grãos, começam a se destacar de maneira importante no processo de desgaste como mostra a figura 5.19 (c). No detalhe anexo à figura 5.19 (c) verifica-se a presença de dano por excesso de deformação plástica em contornos de grão altamente danificados, embora a perda de massa ainda não é suficiente para ser quantificada. Entretanto, regiões que ainda não foram deformadas o suficiente para ultrapassar a tenacidade à fratura do material continuam a se deteriorar por deformação plástica devido à ação dos campos de tensões cisalhantes decorrentes da implosão das bolhas formadas no processo de cavitação.

Outro aspecto que pode ser observado na sequência de micrografias da figura 


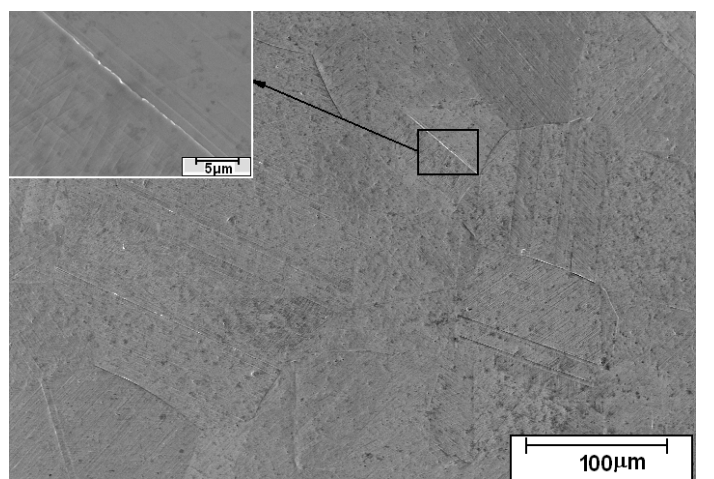

(a) $4 \mathrm{~h}$ EC

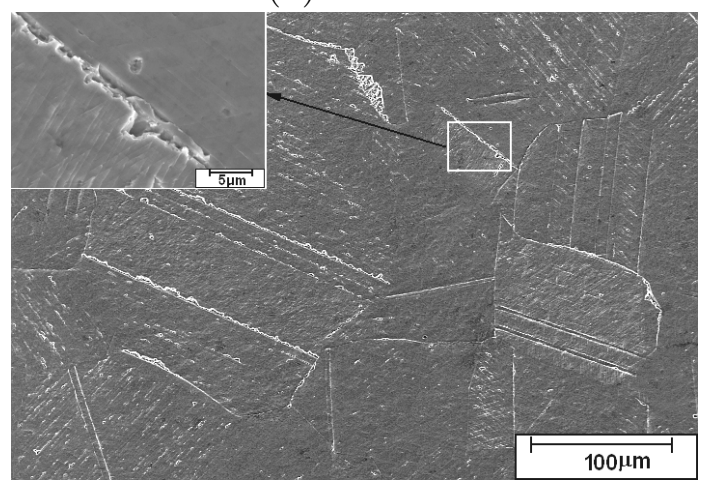

(c) $16 \mathrm{~h} \mathrm{EC}$

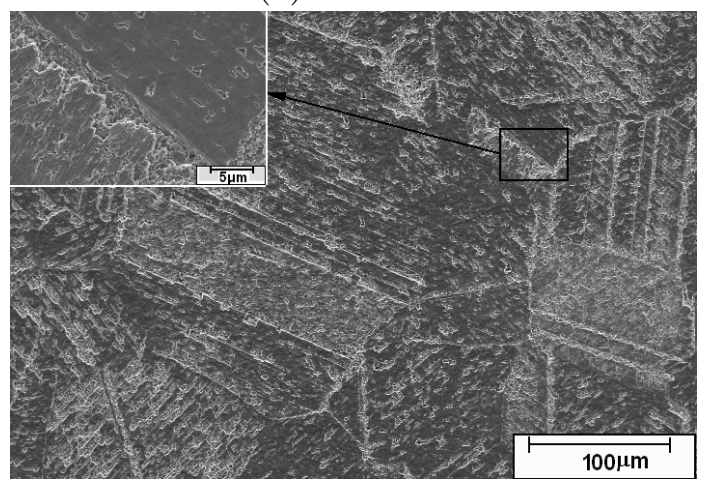

(e) $36 \mathrm{~h} \mathrm{EC}$

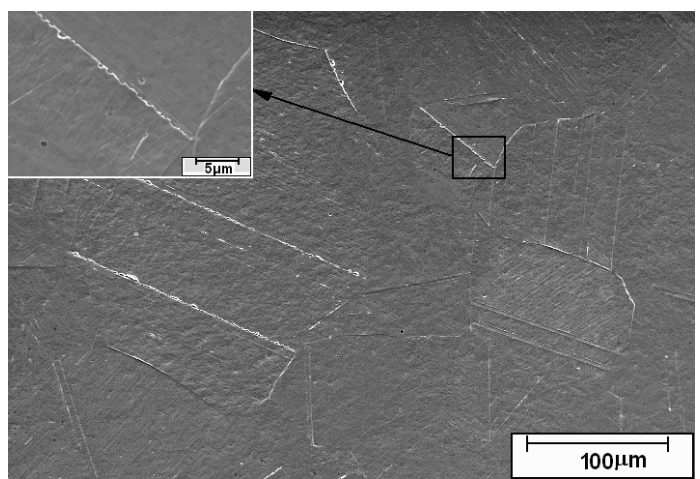

(b) $9 \mathrm{~h} \mathrm{EC}$

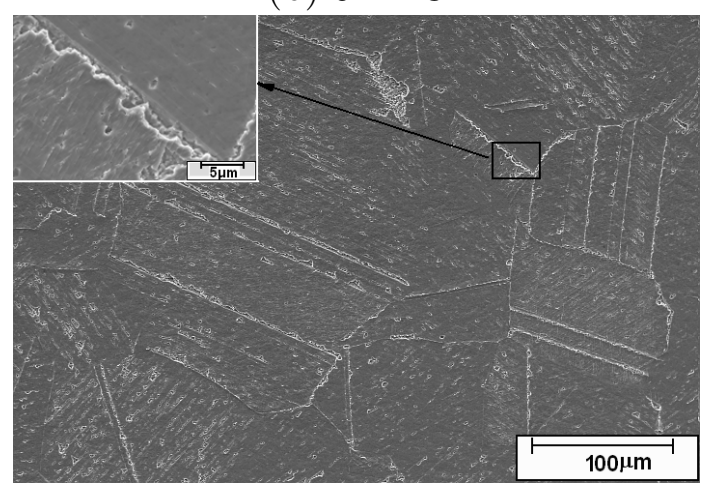

(d) $25 \mathrm{~h} \mathrm{EC}$

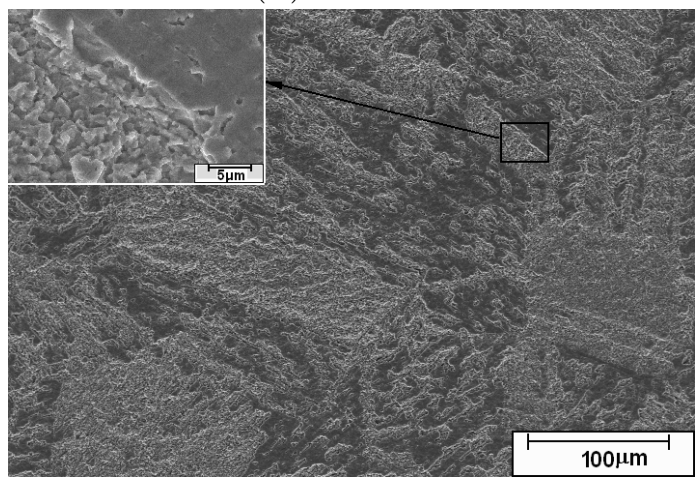

(f) $64 \mathrm{~h} \mathrm{EC}$

Figura 5.19: Micrografias MEV mostrando a evolução do processo de desgaste EC no aço 318HTGN+Sol para (a) 4 h, (b) 9 h, (d) 16 h, (d) 25 h, (e) 36 h e (f) $64 \mathrm{~h}$ de ensaio de desgaste por EC.

5.19 e nos seus detalhes é a forma heterogênea com que o desgaste atua tanto nos contornos quanto no interior dos grãos. Verifica-se que nem todos os contornos e nem todos os grãos se desgastam igualmente, o que faz pensar que as tensões decorrentes da implosão de bolhas de cavitação atuam de forma independente. A heterogeneidade do dano pode ser visualizada nas figuras 5.19 (e) e (f), onde se observam grãos completamente danificados e grãos que mantêm, para elevados tempos de ensaio, parte da sua superfície em bom estado de conservação (regiões escuras), embora altamente deformada. Foi observado, também, que desde os estágios iniciais de perda de massa, até tempos avançados de ensaio, grãos muito danificados estão próximos a outros praticamente intactos, provavelmente devido 
às diferenças de orientação cristalográfica entre eles. A diferença de orientação entre grãos vizinhos pode fazer com que as tensões de cisalhamento projetadas e decompostas em alguns sistemas de escorregamento pertencentes a esses grãos conseguem ou não provocar escoamento, de acordo com a lei de Schmid ou com a lei de Taylor (vide seção 2.4.1).

Para tempos de ensaio acima de 25 horas, verifica-se a competição entre mecanismos de desgaste, em que a deformação plástica deixa de ser o mecanismo principal para dar lugar à fratura frágil, depois que a superfície, possivelmente, acumulou danos por fadiga de baixo ciclo. Para este tempo de ensaio o desgaste da superfície ocorre predominantemente pelo destacamento de micro-plaquetas, como pode ser observado na figura 5.20.

Evidências da ocorrência de alta deformação plástica no interior dos grãos podem ser observadas na figura 5.21, onde são vistos degraus, que talvez sejam estrias de fadiga existentes nas paredes dos grãos cujos vizinhos foram já arrancados.

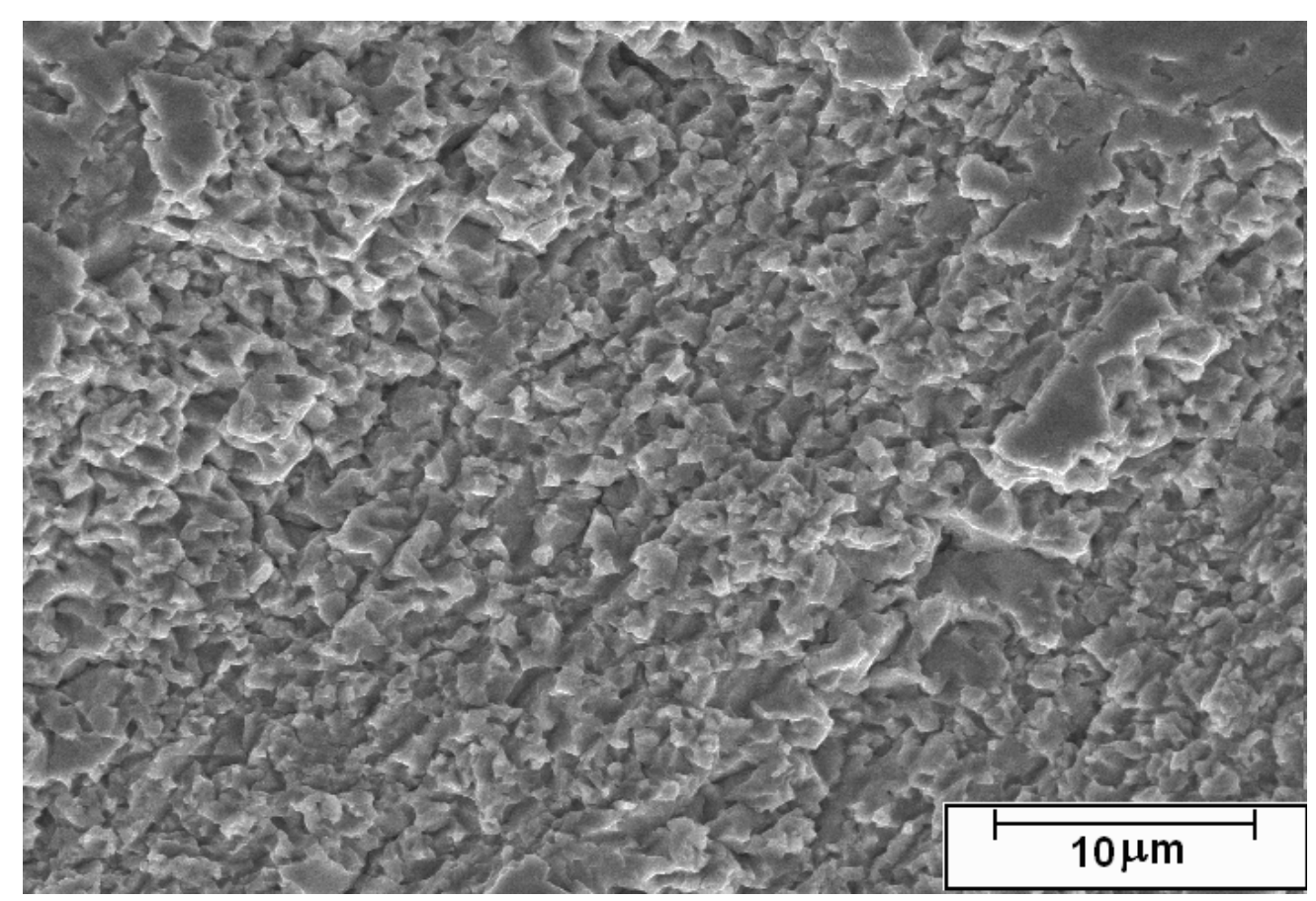

Figura 5.20: Micrografia MEV onde é apresentada a aparência superficial da amostra de aço 318HTGN+Sol ensaiada em EC por 49 horas mostrando evidências de desgaste por arranque de micro-plaquetas por fratura frágil .

O aço 318HTGN+Sol, que apresentou textura preferencial e um maior tamanho de grão do que o aço 318HTGN+Lam+Sol, também apresentou um maior tempo de incubação para o início do dano, assim como uma menor taxa de desgaste dentre os materiais da tipo 1. Este comportamento indica que o refinamento de grão, embora tenha-se mostrado como um fator adequado 


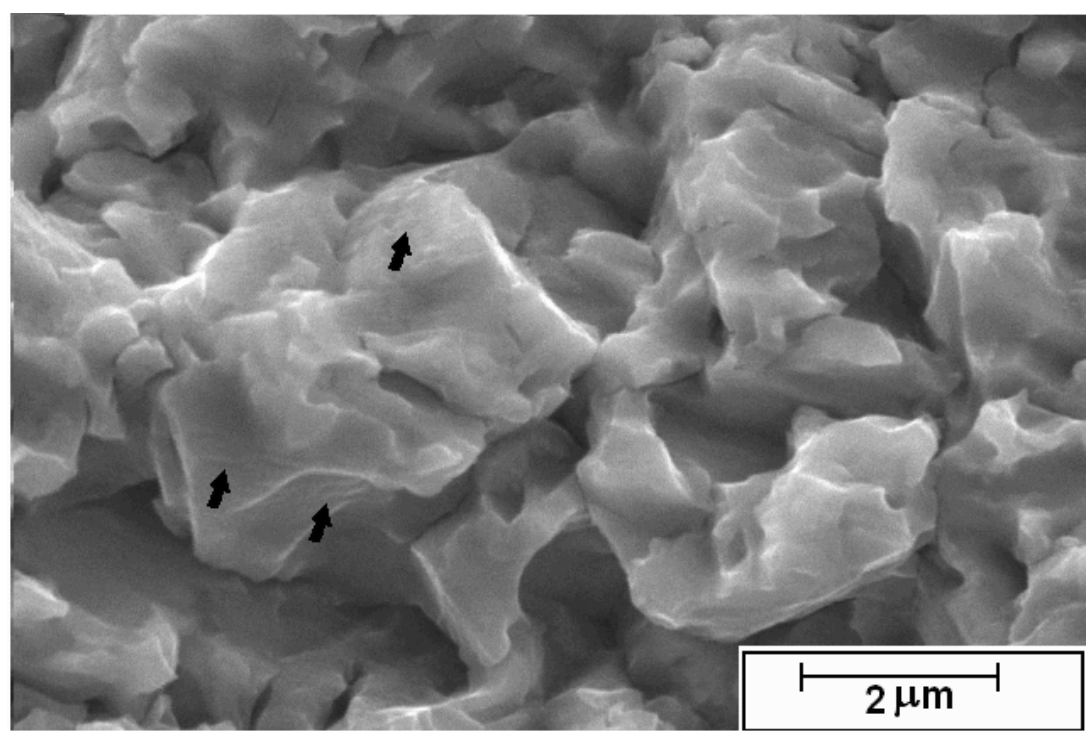

Figura 5.21: Micrografia MEV onde se apresenta a aparência da superfície cavitada no aço 318HTGN+Sol ensaiada por 49 horas mostrando estrias de fadiga, indicativas da ocorrência desse mecanismo de falha.

para melhorar a resistência à EC, por ser fundamentalmente um mecanismo de endurecimento que não deteriora a tenacidade, neste caso, a melhora da resistência ao desgaste, como consequência da orientação preferencial dos grãos é mais significativa (evidenciada nas amostras do aço 318HTGN+Sol). Em outras palavras, o efeito benéfico do aumento da fração de grãos que possuem maiores valores de tensão cisalhante projetada crítica para escoamento, mostrou-se mais acentuado que o efeito deletério da diminuição da fração de contornos de grão, que atuam como obstáculo para a propagação da deformação plástica.

\subsubsection{Aço 318 nitretado, laminado e solubilizado (318HTGN+Lam+Sol, amostra 2).}

A figura 5.22 mostra micrografias, onde se observam as regiões preferenciais de dano durante o período de incubação, para um tempo de ensaio EC de 4 horas no aço 318 HTGN+Lam+Sol.

Da mesma forma que para o aço $318 \mathrm{HTGN}+\mathrm{Lam}+$ Sol, pode-se notar que para o aço 318HTGN+Lam+Sol, micrografias (a) e (b) da figura 5.22, que as regiões de início do dano por EC são semelhantes em ambos os aços. Nota-se que durante o período de incubação alguns contornos de grão e bandas de deslizamento são as regiões onde se apresenta o início do dano. Na micrografia geral da figura 5.22 é possível notar também que o desgaste é mais acentuado em alguns contornos e no interior de alguns grãos do que em outros, confirmando o modo heterogêneo em que este fenômeno se apresenta. 


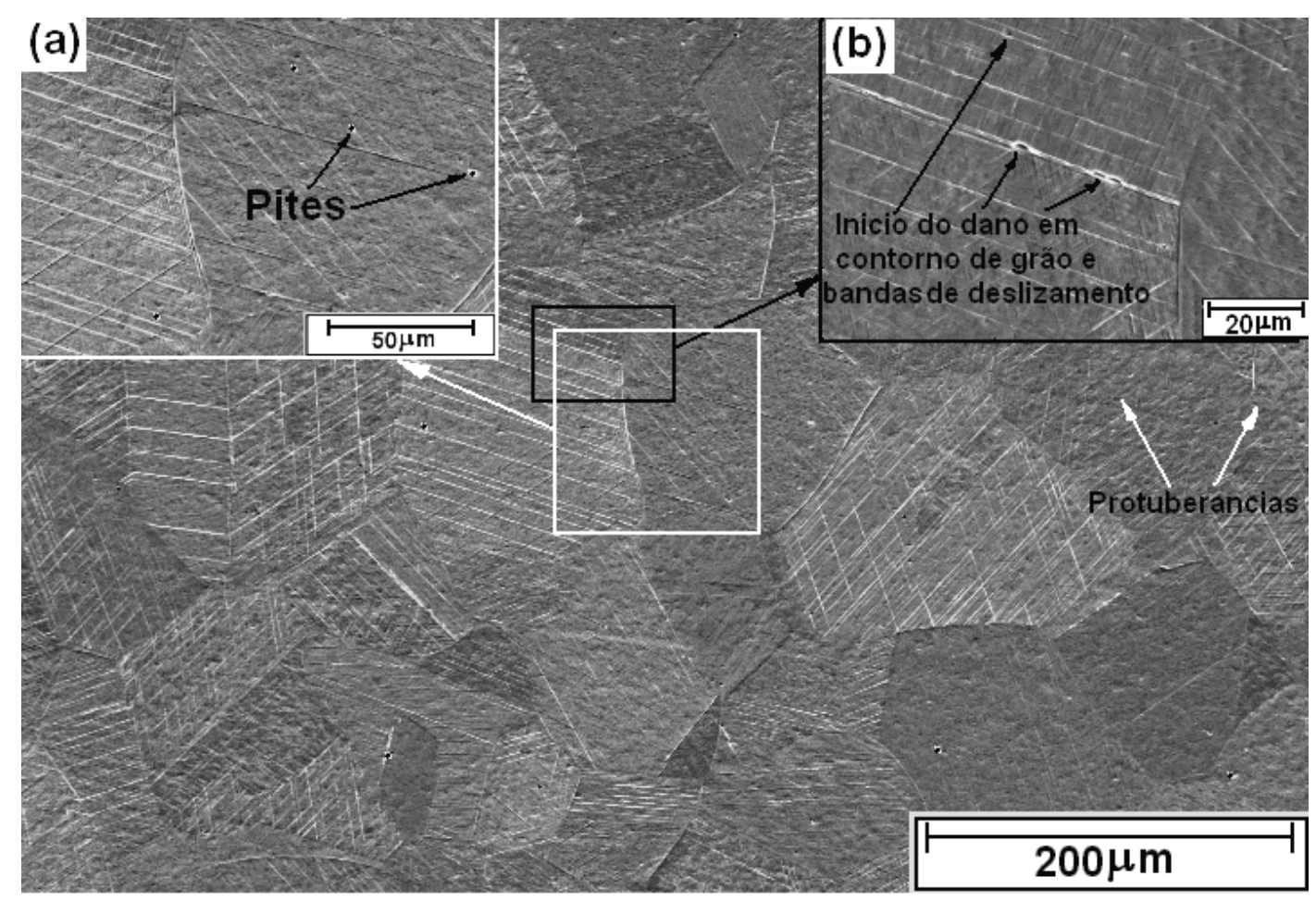

Figura 5.22: Micrografia MEV onde se apresentam as regiões de início do dano durante o período de incubação do desgaste EC para o aço

$$
\text { 318HTGN+Lam+Sol. }
$$

Nas figuras 5.23 (a) a (f) é apresentada uma sequência de micrografias do aço 318HTGN+Lam+Sol ensaiado em EC por 4, 9, 16, 25, 36 e 64 horas. Nessas micrografias é possível observar o avanço do dano como também a sua distribuição heterogênea durante todo o intervalo de duração dos ensaios, tanto nos contornos quanto no interior dos grãos.

No que diz respeito aos mecanismos de desgaste operantes no aço 318HTGN+Lam+Sol, e observando a sequência de micrografias exibidas na figura 5.23 (a) a (f) e nas micrografias em detalhe anexas, pode-se dizer que, em geral, estes são semelhantes aos discutidos para o aço 318HTGN+Sol, dando a entender que a recristalização após encrumento por laminação afeta somente o tamanho de grão do material, e não há grandes modificações no mecanismo de desgaste. Esta hipótese pode ser verificada nas micrografias apresentadas na figura 5.24 (a) e (b), onde é possível observar que o mecanismo principal de desgaste, para maiores tempos de ensaio e após a superfície ter sido submetida à elevada deformação plástica, é a fratura frágil, em que o arrancamento de material se dá por destacamento de microplaquetas. 


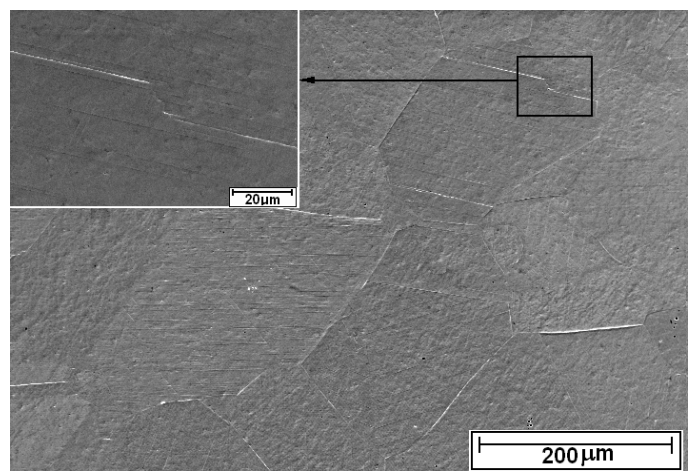

(a) $4 \mathrm{~h}$ EC

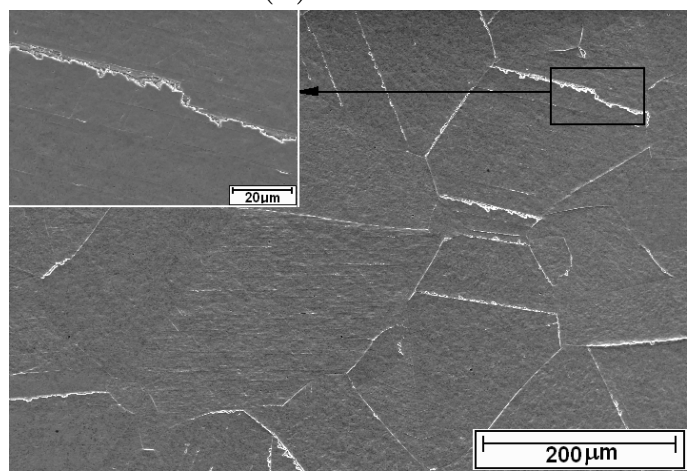

(c) $16 \mathrm{~h} \mathrm{EC}$

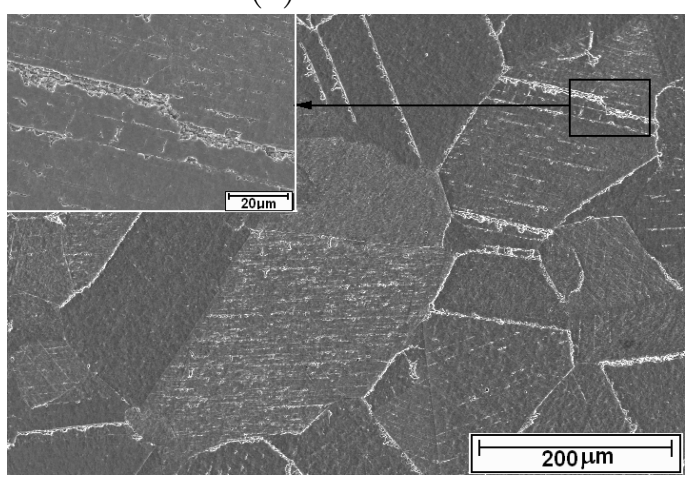

(e) $36 \mathrm{~h} \mathrm{EC}$

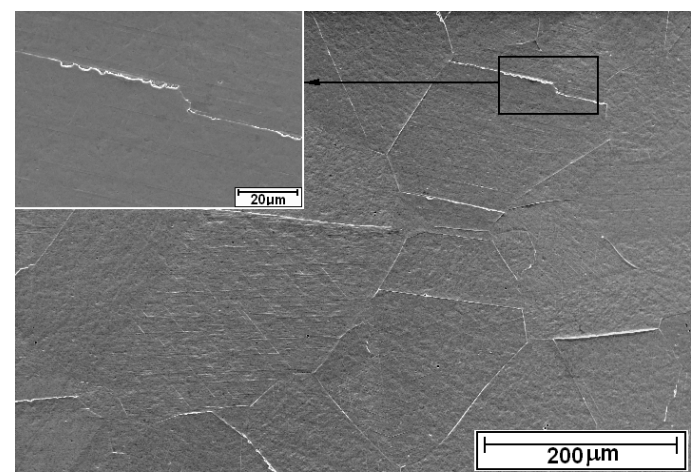

(b) $9 \mathrm{~h} \mathrm{EC}$

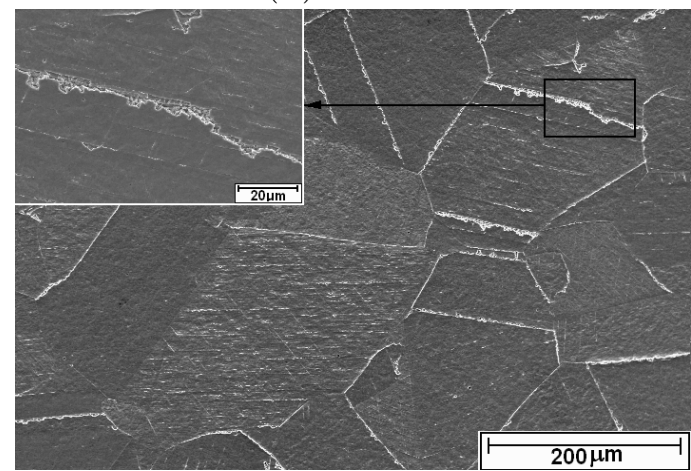

(d) $25 \mathrm{~h} \mathrm{EC}$

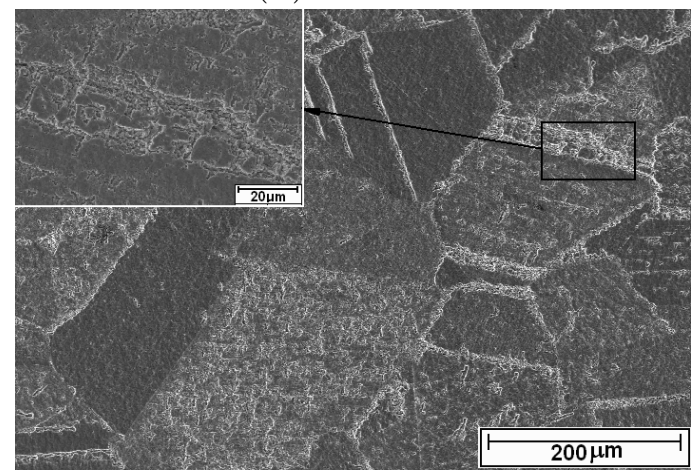

(f) $64 \mathrm{~h} \mathrm{EC}$

Figura 5.23: Micrografias MEV apresentando a evolução do processo de desgaste EC no aço 318HTGN+Lam+Sol para (a) 4 h, (b) 9 h, (d) 16 h, (d) 25 $\mathrm{h},(\mathrm{e}) 36 \mathrm{~h}$ e (f) $64 \mathrm{~h}$ de ensaio.

\subsubsection{Aços inoxidáveis com estrutura completamente austenítica e encruados (tipo 2)}

5.2.2.1 Aço 318 nitretado a gás e encruado (318HTGN+Enc, amostra 3).

$\mathrm{Na}$ figura 5.25, vê-se o aspecto geral da superfície do aço 318HTGN+Enc, nitretado em alta temperatura e deformado por laminação (redução em 30 \% da espessura), ensaiada em EC por 4 horas.

Observando a micrografia da figura 5.25, vê-se que o encruamento, provocou encurvamento de parte dos contornos de grão. A laminação também introduziu 


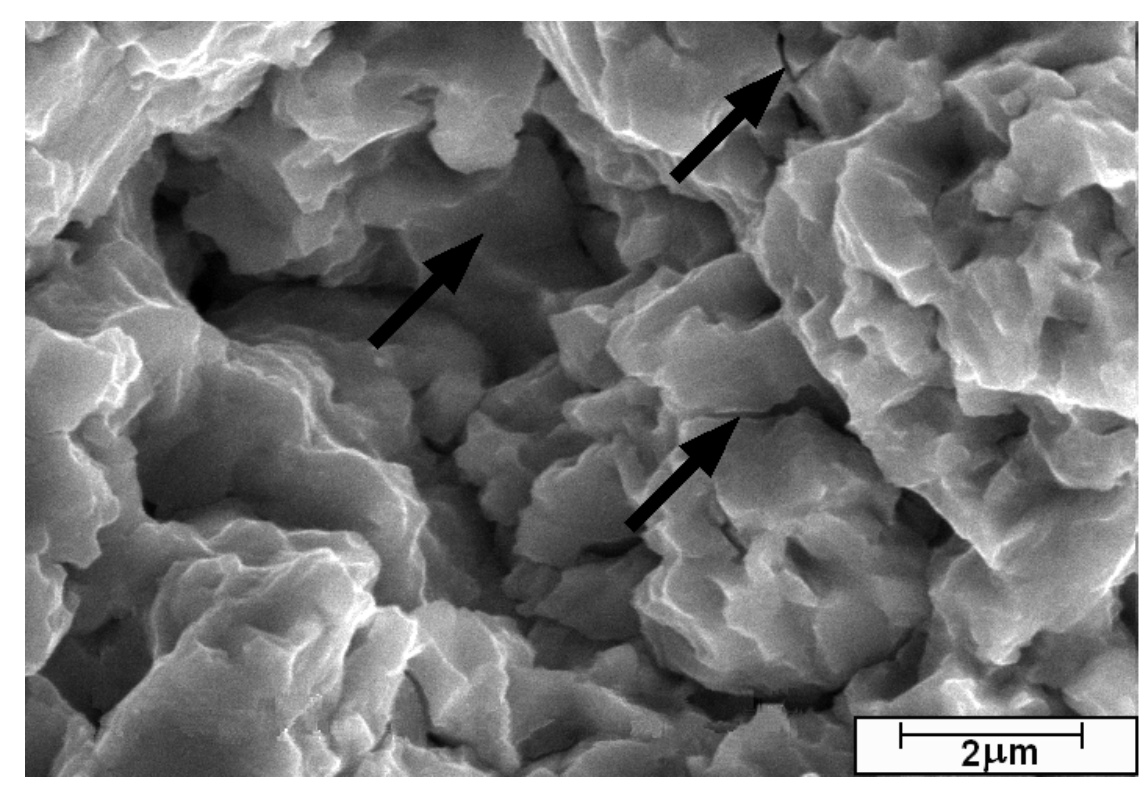

(a)

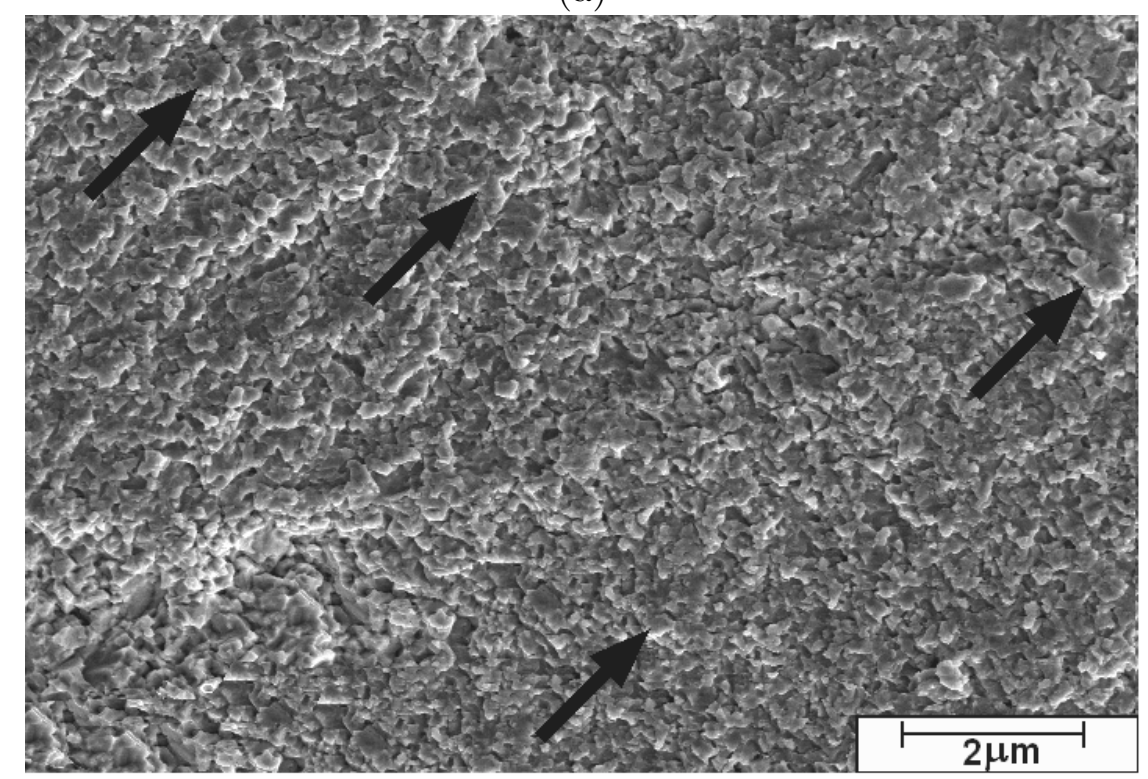

(b)

Figura 5.24: Micrografias MEV do aço 318HTGN+Lam+Sol, onde se mostra (a) o destacamento de material por fratura frágil decorrente da alta deformação plástica sofrida pela superfície, (b) micro-lascamento.

uma série de defeitos superficiais como incrustações de partículas estranhas, as quais permaneceram na superfície após polimento, porém, com o passar do tempo de ensaio foram desaparecendo. Esses defeitos podem ser observados nos detalhes da figura 5.25.

No que diz respeito aos mecanismos de desgaste presentes, observa-se que para as primeiras horas de ensaio houve uma intensa deformação plástica da superfície na forma de ondulações que deram origem à formação de pites, não tendo sido identificadas bandas de escorregamento, como ocorreu com os aços do tipo 1 (aços inoxidáveis nitretado e solubilizados). Outros mecanismos de 

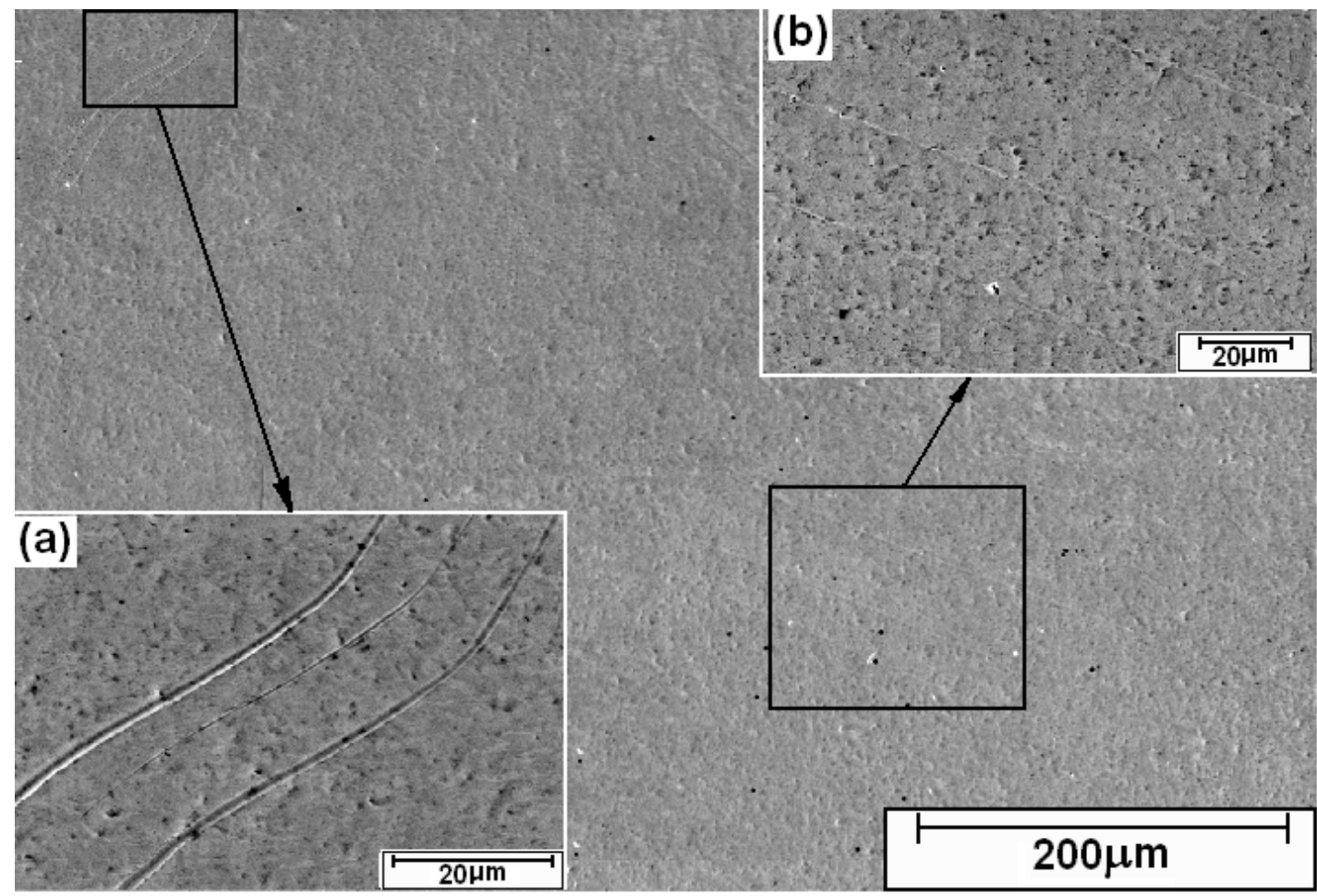

Figura 5.25: Micrografia MEV geral do aço 318HTGN+Enc ensaiado em EC por 4 horas em EC. O detalhe (a) mostra o curvamento de alguns contornos devido à deformação e o detalhe (b) mostra micro-pites formados nas incrustações decorrentes do processo de laminação.

desgaste presentes durante as diferentes etapas da EC, dessa amostra, podem ser verificados na sequência de micrografias da figura 5.26 (a) a (f) para o aço 318HTGN+Enc ensaiado por 4, 9, 16, 25, 36 e 64 horas.

Em geral, o aço 318HTGN+Enc apresentou uma alta resistência ao desgaste por EC, contendo apenas leves sinais de dano até 16 horas de ensaio, tempo em que somente se observa a presença de ondulações, pequenos pites e contornos de grão levemente danificados como pode ser verificado nas micrografias (a), (b) e (c) da figura 5.26. A partir de 16 horas de ensaio, um maior número de contornos de grão começa a apresentar sintomas de dano, como pequenas protuberâncias e microreelevo causado por deformação plástica, porém a quantidade de material arrancado da superfície ainda não é mensurável, pois o tempo de incubação é próximo de 30 horas, como verificado na curva de perda de massa em função do tempo de ensaio (figura 5.16).

Após 30 horas de ensaio, ondulações presentes no interior dos grãos tornam-se regiões preferenciais para o início do dano por formação de microtrincas, porém nem todos os grãos apresentam deterioração homogênea como pode ser observado nas micrografias apresentadas nas figuras 5.26 (d) e (e).

Uma hipótese que pode explicar a alta resistência ao desgaste por EC 


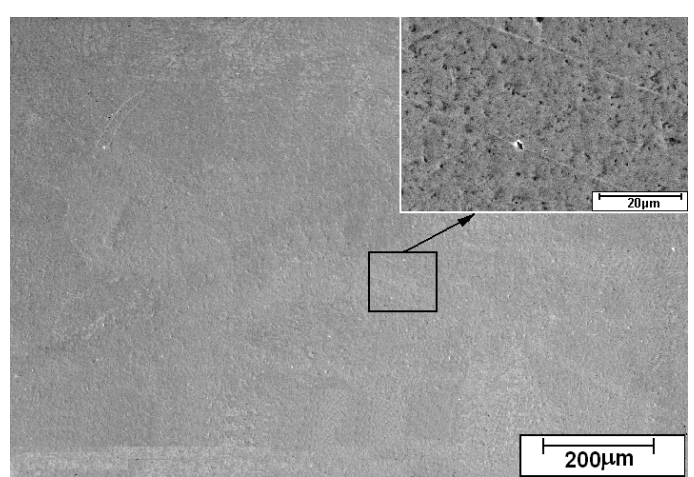

(a) $4 \mathrm{~h}$ EC

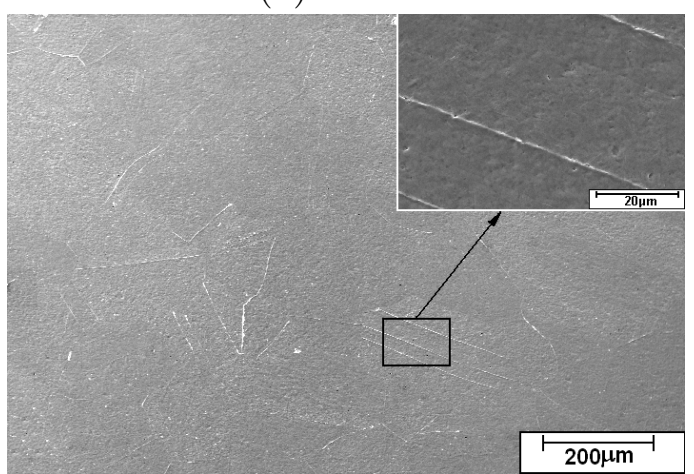

(c) $16 \mathrm{~h} \mathrm{EC}$

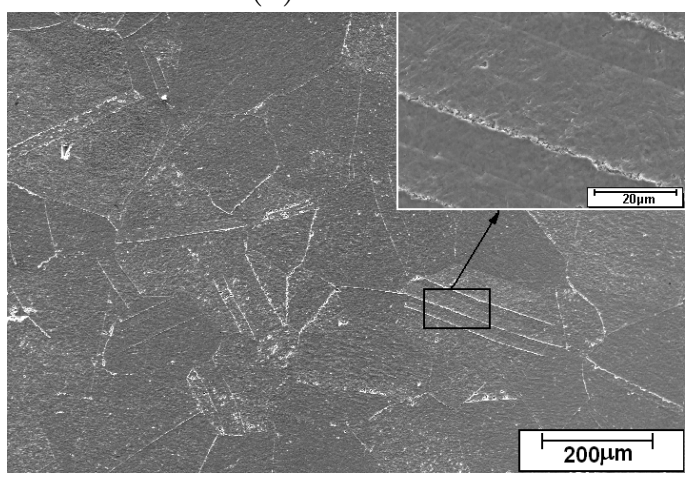

(e) $36 \mathrm{~h} \mathrm{EC}$

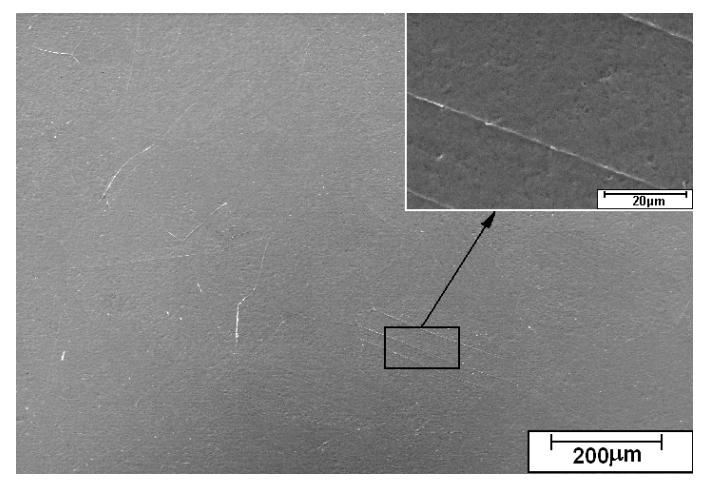

(b) $9 \mathrm{~h} \mathrm{EC}$

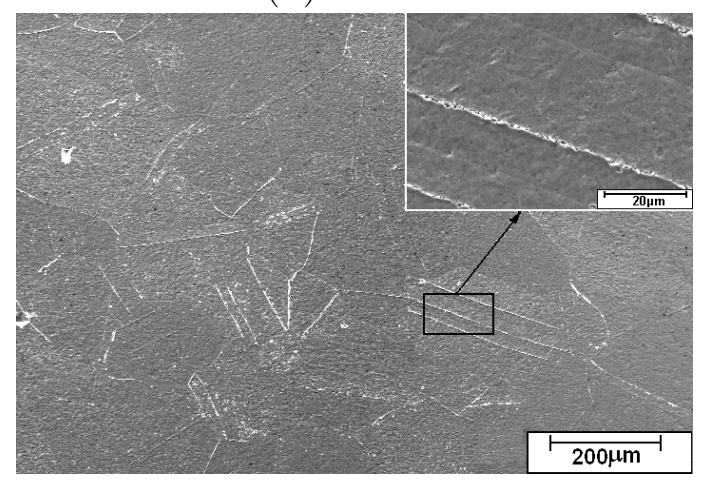

(d) $25 \mathrm{~h} \mathrm{EC}$

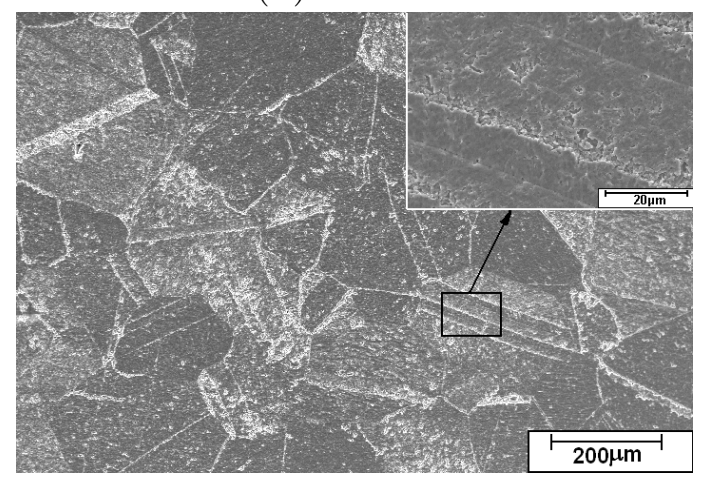

(f) $64 \mathrm{~h} \mathrm{EC}$

Figura 5.26: Micrografias MEV mostrando a evolução do processo de desgaste EC no aço 318HTGN+Enc para (a) 4 h, (b) 9 h, (c) 16 h, (d) 25 h, (e) $36 \mathrm{~h} \mathrm{e}$ (f) $64 \mathrm{~h}$ de ensaio.

do aço 318HTGN+Enc está relacionada com o mecanismo de endurecimento por deformação (encruamento). Isto é, quando um material é deformado a frio são geradas discordâncias, que formam emaranhados e estruturas tipo floresta, dificultando a deformação plástica. Para tempos maiores de ensaio, os emaranhados de discordâncias, formados durante a deformação do material, se tornam sítios nucleadores de dano. A pouca capacidade de deformação plástica explica a ausência de bandas de deslizamento no material durante todo o tempo em que foram realizados os ensaios de desgaste como se pode observar nas micrografias da figura 5.26. 


\subsubsection{Aços inoxidáveis com estrutura austenítica con- tendo dispersão de nitretos (tipo 3)}

\subsubsection{Aço 318 com dispersão de nitretos (318HTGN+Nit, amostra 4).}

As micrografias das figuras 5.27 (a) e (b), para o aço 318 com dispersão de nitretos, apresentam as primeiras evidências do desgaste EC na superfície, após o aço ter sido ensaiado por 4 e 9 horas.

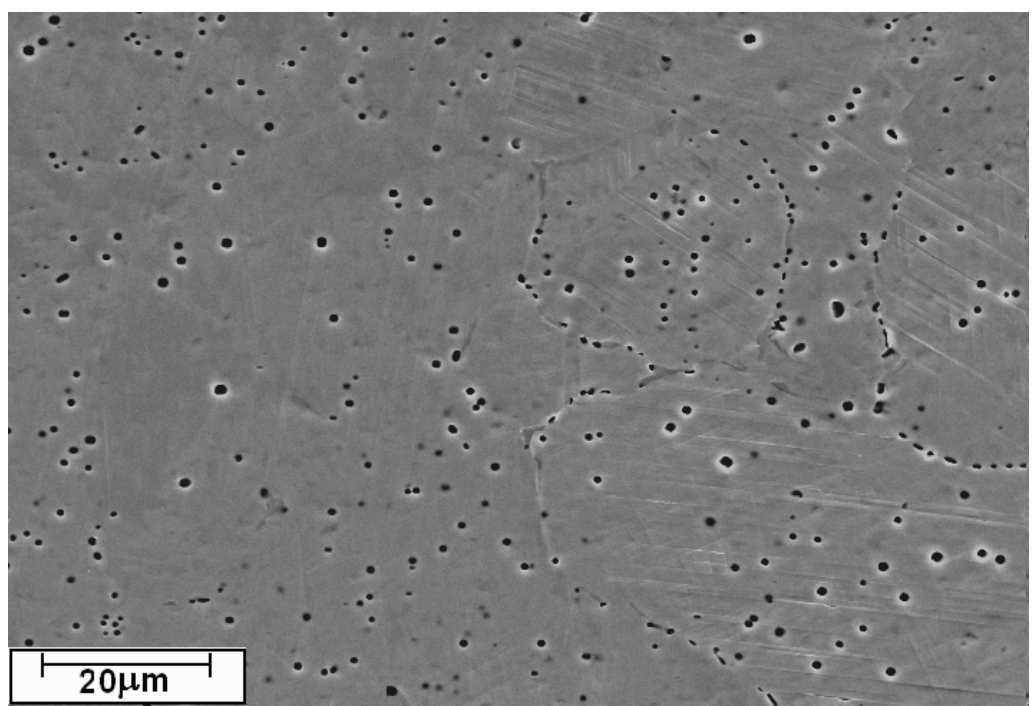

(a)

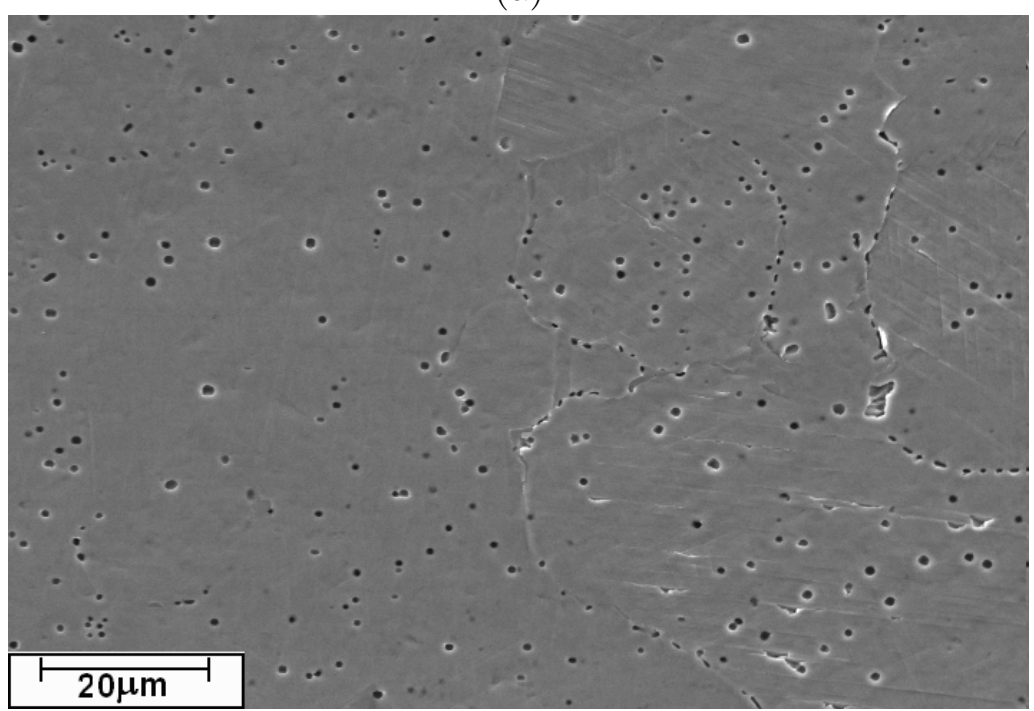

(b)

Figura 5.27: Micrografias MEV onde se apresenta as regiões de inicio do dano por EC no aço 318HTGN+Nit para (a) 4 horas e (b) 9 horas de ensaio.

Na micrografia da figura 5.27 (a) observa-se que para as primeiras 4 horas de ensaio EC tem-se principalmente destacamento dos nitretos da superfície e aparecimento de bandas de deslizamento. Já para 9 horas de ensaio, a micrografia da figura 5.27 (b) mostra que o início do dano ocorre principalmente nessas bandas 
de deslizamento e em vazios deixados pelos nitretos destacados.

O acompanhamento do desgaste e a análise dos mecanismos de desgaste, para tempos de ensaio maiores que 9 horas, pode ser realizado com ajuda das micrografias apresentadas nas figuras 5.28 (a) a (d) para 16, 25, 36 e 64 horas de ensaio EC.

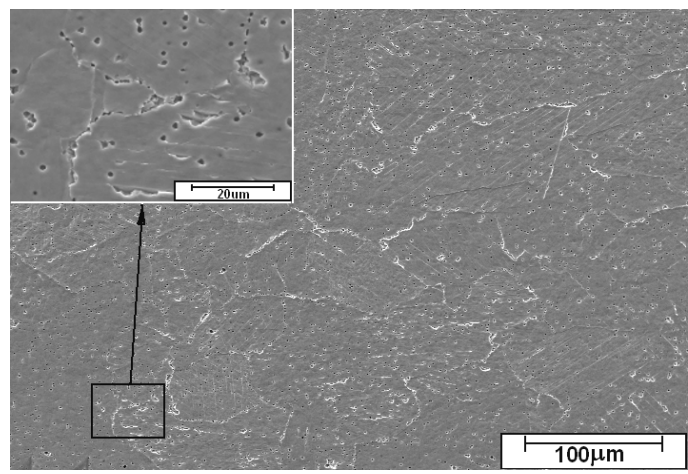

(a) $16 \mathrm{~h} \mathrm{Ec}$

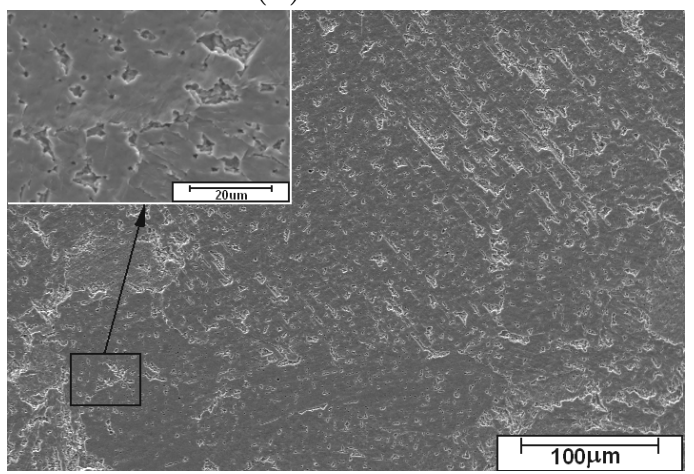

(c) $36 \mathrm{~h} \mathrm{EC}$

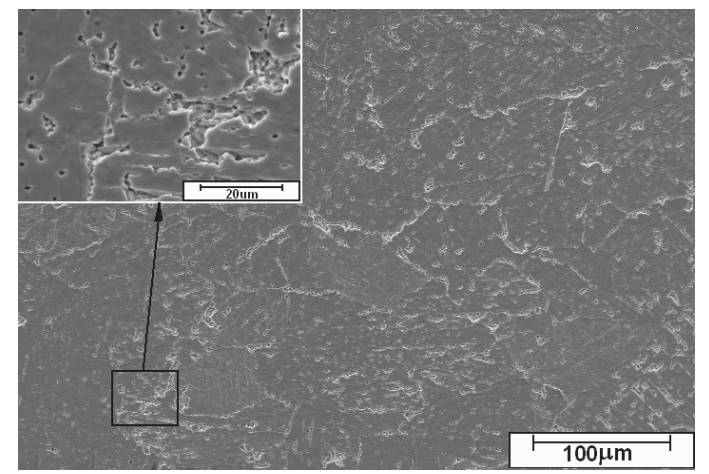

(b) $25 \mathrm{~h} \mathrm{EC}$

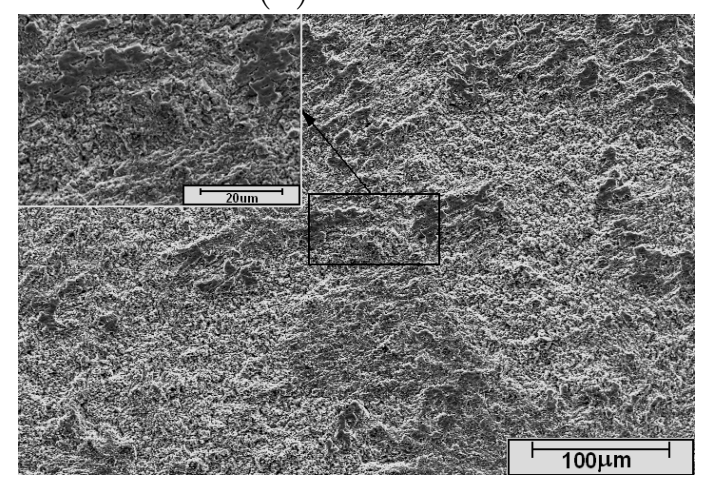

(d) $64 \mathrm{~h} \mathrm{EC}$

Figura 5.28: Micrografias MEV mostrando a evolução do processo de desgaste EC para o aço 318HTGN+Nit para: (a) 16 h, (b) 25 h, (c) $36 \mathrm{~h}$ e (d) $64 \mathrm{~h}$ de ensaio.

Observando as figuras 5.28 (a) e 5.29, para 16 horas de desgaste EC, há três locais preferenciais para o início do dano no aço 318HTGN+Enc, sendo estes:

(i) contornos de grão;

(ii) crateras deixadas pelos nitretos destacados no interior dos grãos; e

(iii) bandas de deslizamento, como mostrado na micrografia da figura 5.29 (a).

Para longos tempos de ensaio (64 horas), em vários dos locais onde se visualiza material arrancado, evidencia-se a presença de um mecanismo de dano por deformação plástica, em função de estrias de fadiga observadas na figura 5.29 (b). 


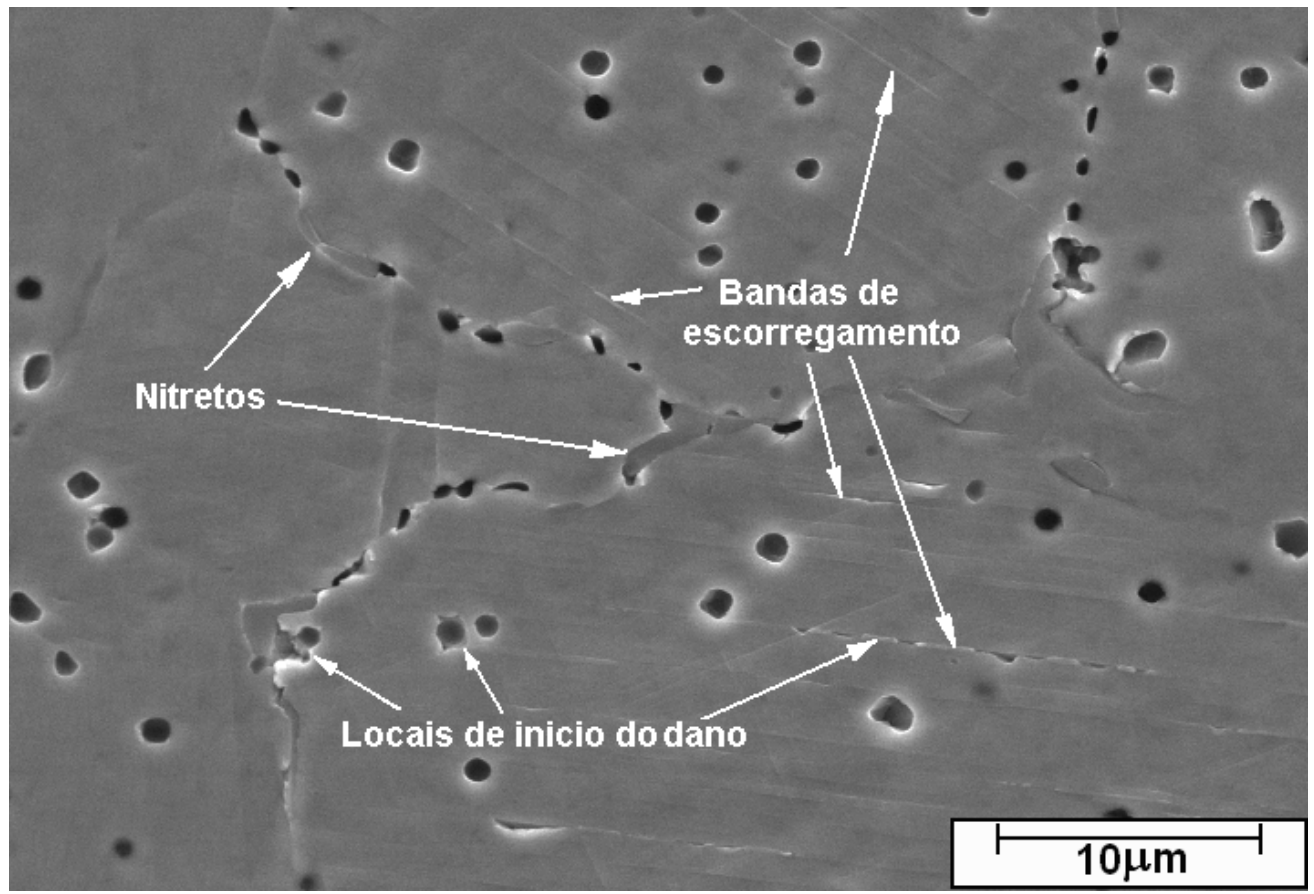

(a)

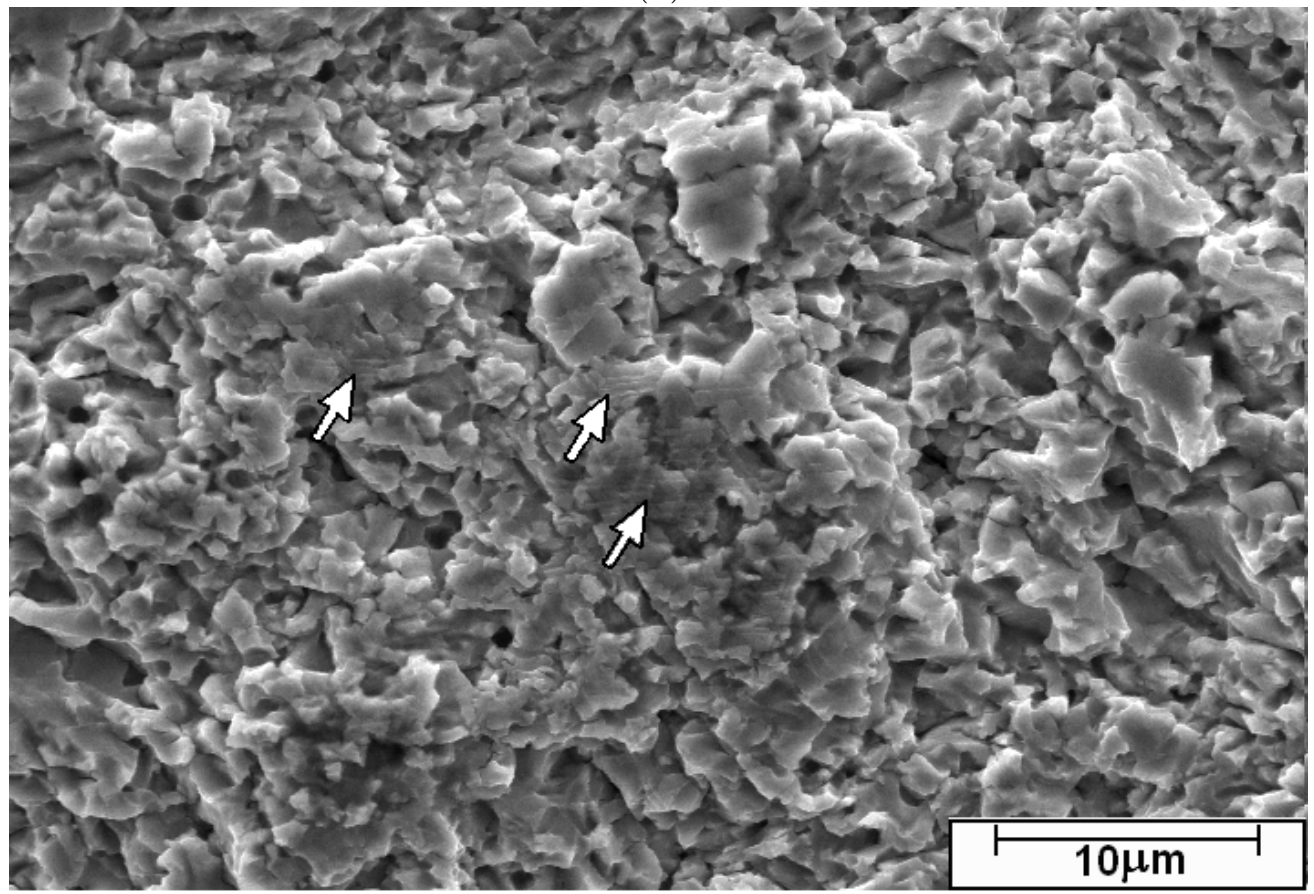

(b)

Figura 5.29: Micrografias MEV para o aço 318HTGN+Nit onde se apresentam: (a) locais de início de dano e (b) evidência de desgaste por fratura frágil decorrente da intensa deformação plástica sofrida pela superfície . As setas mostram evidencias de possíveis estrias de fadiga.

\subsection{Aços inoxidáveis nitretados a plasma com estrutura de austenita expandida (tipo 4)}

5.2.4.1 Aço 318 nitretado a gás e nitretado a plasma (318HTGN+Plas, amostra 5).

Na figura 5.30 é apresentado o início do dano para o aço 318 nitretado a gás e posteriormente nitretado a plasma, para 4 horas de ensaio por EC 


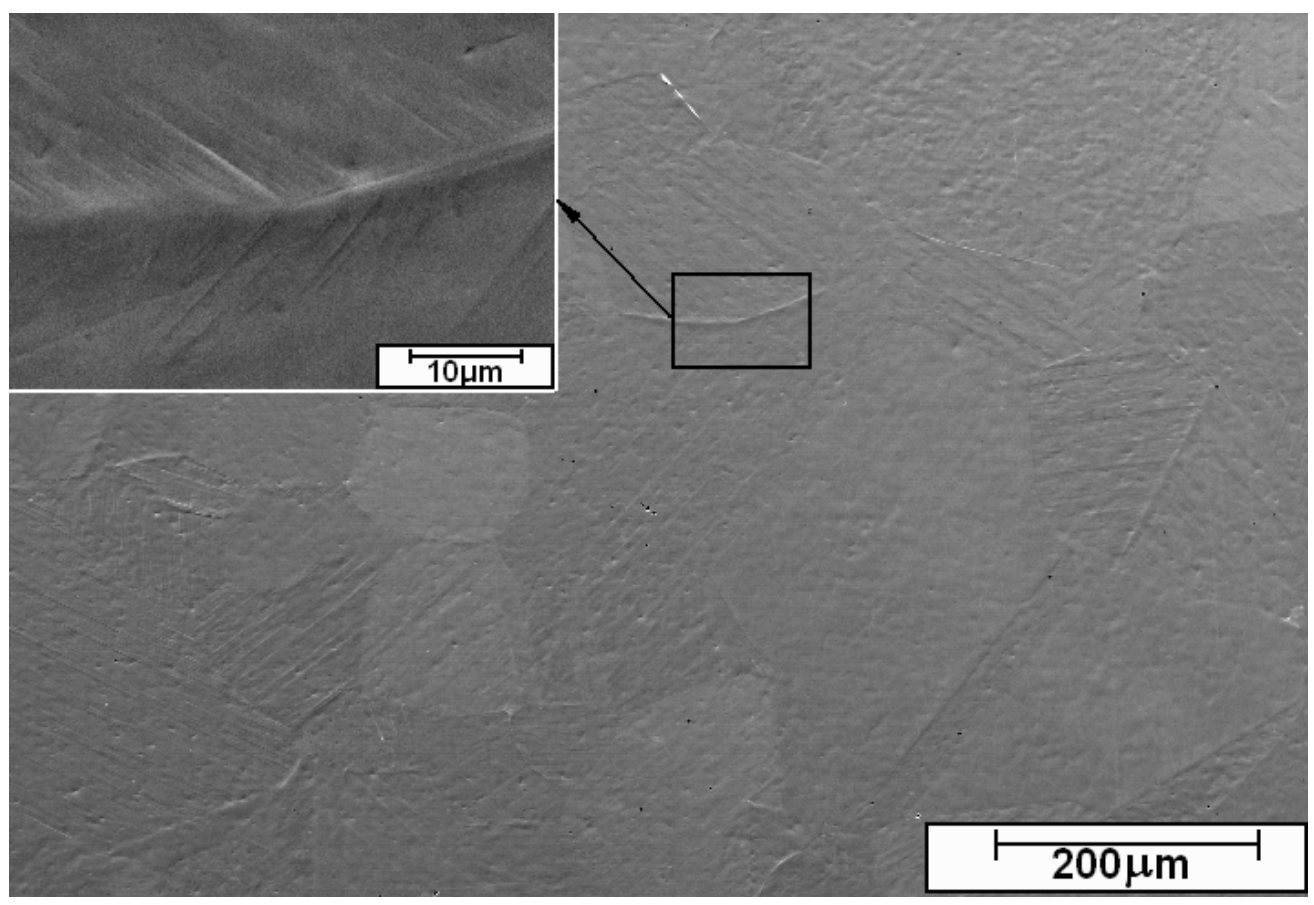

Figura 5.30: Micrografia MEV onde se apresentam os locais de início do dano no aço 318HTGN+Plas para 4 horas de ensaio por EC.

Na figura 5.30 nota-se que o início do dano por desgaste EC, no aço 318HTGN+Plas, ocorre com deformação plástica, evidenciada pela presença de uma superfície rugosa e pelo surgimento de bandas de escorregamento, além de alguns contornos levemente danificados. Esse comportamento é similar ao dos aços do tipo nitretados a gás, com a diferença que a superfície se encontra bem menos danificada para o mesmo tempo de ensaio, neste caso 4 horas.

A elevada resistência ao desgaste EC da camada de austenita expandida, devese à elevada resistência à deformação plástica, conferida pela colossal entrada de intersticiais de nitrogênio, dissolvido na rede cristalina da austenita, atingindo um teor aproximado de $20 \%$ em massa. O forte endurecimento por solução sólida intersticial da austenita dificulta a deformação plástica, diminuindo o número de locais onde ocorre iniciação de dano por cavitação durante as primeiras etapas do dano, principalmente nos contornos de grão.

O avanço do dano com o tempo pode ser acompanhado observando as micrografias (a) a (f) da figura 5.31, onde se observa o modo de ação da EC. Nessas micrografias são mostrados, também, detalhes que explicam melhor os mecanismos de desgaste para cada tempo de ensaio avaliado, isto é, para 4, 9, 16, 25, 36 e 64 horas de EC.

Das micrografias (a) a (f) da figura 5.31 pode-se observar que em geral, a resistência ao desgaste do aço 318HTGN+Plas é bastante elevada, quando comparada com a dos aços contendo $0,9 \% \mathrm{~N}$ em massa, não encruados, pois 


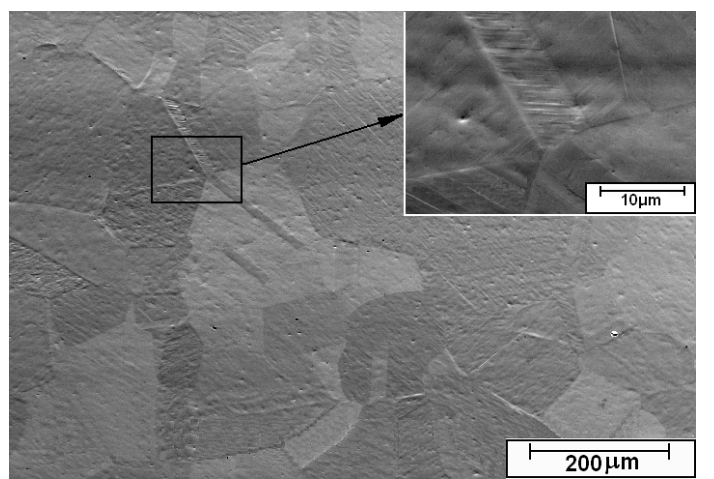

(a) $4 \mathrm{~h}$ EC

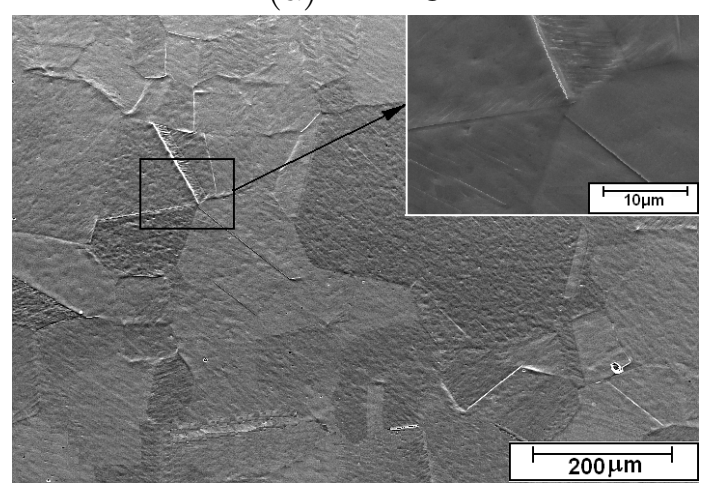

(c) $16 \mathrm{~h} \mathrm{EC}$

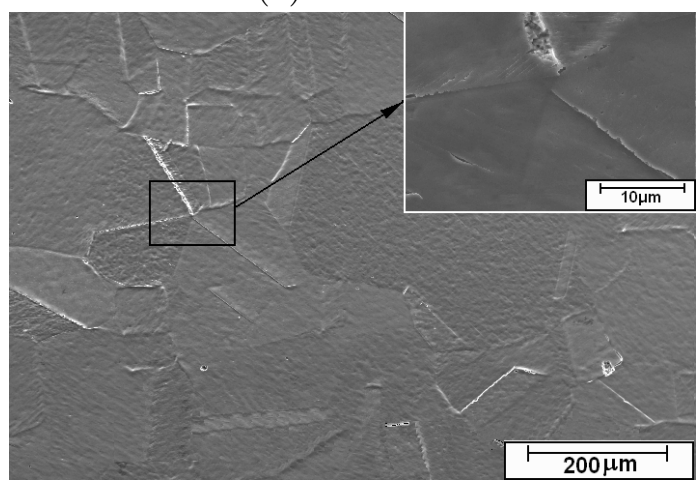

(e) $36 \mathrm{~h} \mathrm{EC}$

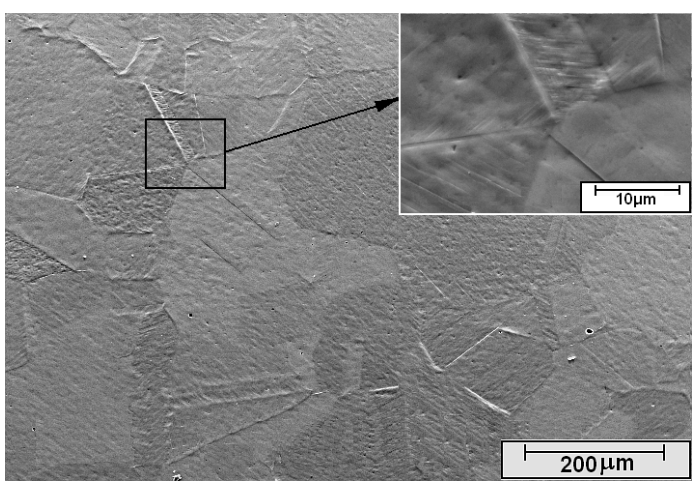

(b) $9 \mathrm{~h} \mathrm{EC}$

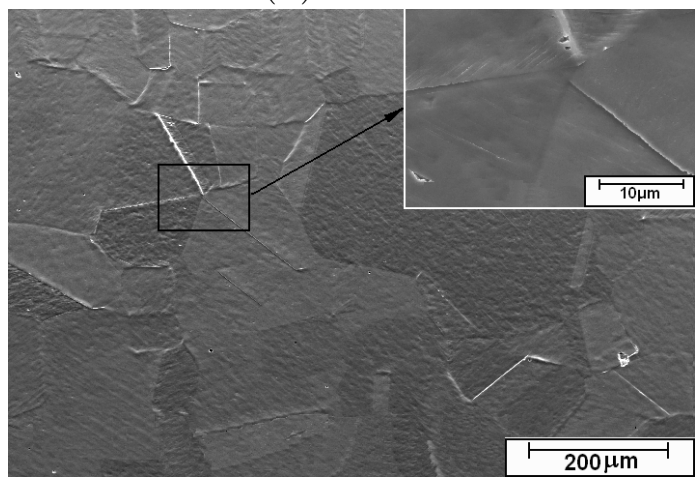

(d) $25 \mathrm{~h} \mathrm{EC}$

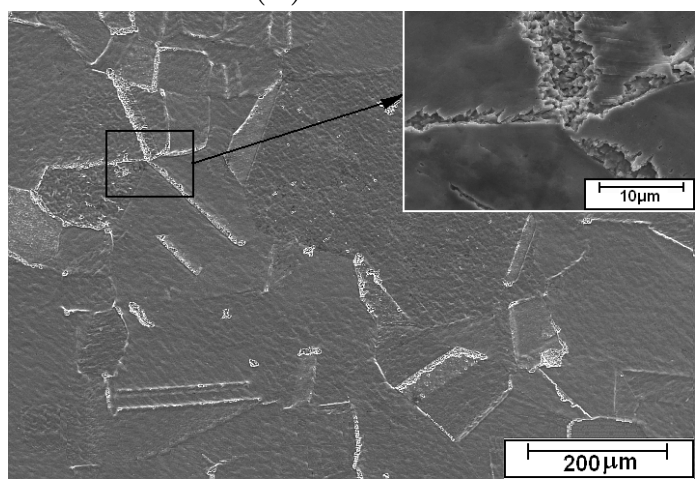

(f) $64 \mathrm{~h} \mathrm{EC}$

Figura 5.31: Micrografias MEV onde se apresenta a evolução do processo de desgaste no aço 318HTGN+Plas para (a) 4 h, (b) 9 h, (d) 16 h, (d) 25 h, (e) 36 $\mathrm{h}$ e (f) $64 \mathrm{~h}$ de ensaio de desgaste por EC.

somente para 64 horas de ensaio, os contornos de grão e bandas de deslizamento formadas mostraram-se danificados. Já no interior dos grãos se evidencia unicamente a presença de uma leve deformação plástica principalmente na forma de protuberâncias que provocam variações da rugosidade. Outras observações realizadas nas micrografias da figura 5.31, são a fraca evidencia de bandas de deslizamento, para tempos de ensaio abaixo de 64 horas, e a formação de pequena quantidade de pites.

No que diz respeito aos mecanismos de desgaste operantes, as micrografias (a) e (b) da figura 5.31, para 4 e 9 horas de ensaio EC, permitem observar, que durante as primeiras etapas de desgaste, tem-se uma leve deformação plástica da 
superfície, evidenciada principalmente na formação de protuberâncias. Já para as últimas etapas de desgaste, micrografias (e) e (f) respectivamente, para 36 e 64 horas de ensaio, observa-se que o mecanismo principal é o destacamento de pequenos debris por fratura frágil, atuando nos contornos de grão. Porém, quando os contornos de grão têm maior resistência ao desgaste, o dano é iniciado em bandas de deslizamento próximas a estes contornos. Assim quando o dano atinge os contornos há uma tendência de propagação de trincas ao longo deles. Estes fatos podem ser observados nas micrografias (a) e (b) da figura 5.32, para 36 e 64 horas de ensaio respectivamente.

A elevada resistência ao desgaste do aço 318HTGN+Plas pode ser considerada como produto da interação dos seguintes fatores:

(a) elevado endurecimento por solução sólida intersticial (1700 HV0,005);

(b) o efeito benéfico na capacidade de suportar carregamento da camada intermediária de austenita com $0.9 \% N$ em massa, obtida por nitretação gasosa em alta temperatura e de dureza mais elevada, proporcionado uma transição menos brusca de dureza entre a camada de austenita expandida e o núcleo austeno-ferrítico mais mole; e

(c) à presença de tensões residuais de compressão na camada de austenita expandida, desenvolvidas durante o tratamento de nitretação a plasma, que aumentam a resistência à fadiga. (MENTHE et al., 2000).

Para etapas avançadas do desgaste EC, constatou-se que as bandas de deformação são mais evidentes, o que indica que a camada de austenita expandida consegue atrasar a atuação dos mecanismos de desgaste, comumente encontrados nos outros materiais para relativos baixos tempos de ensaio.

Regiões onde se apresenta o dano por EC, para tempos avançados de ensaios podem ser observadas nas micrografias da figura 5.33 (a) a (d).

Nas micrografias apresentadas nas figuras 5.33 (a) a (d ) é possível diferenciar 4 regiões onde o dano por EC atua para tempos avançados de ensaio, e onde os mecanismos de deformação plástica, fratura frágil em contornos de grão, bandas de escorregamento e pites ao interior dos grãos competem provocando uma acelerada degradação da camada de austenita expandida. 


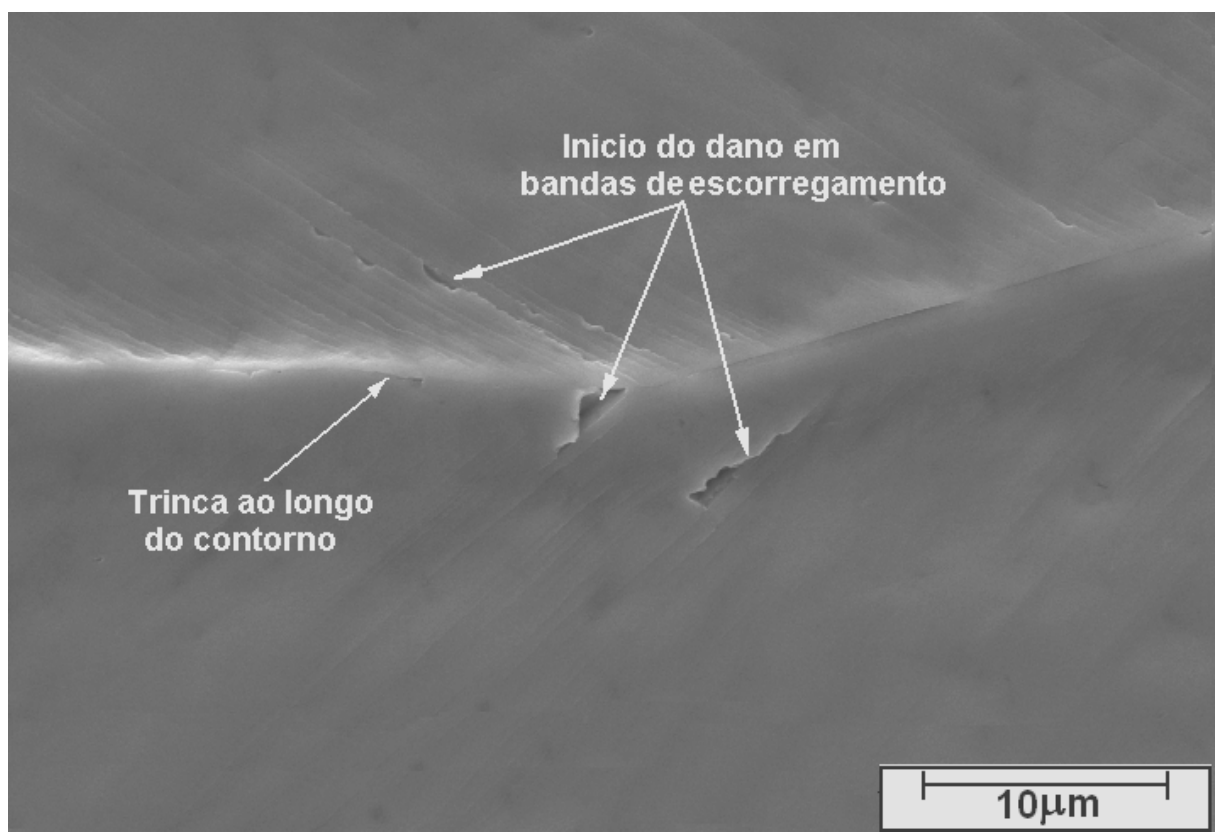

(a) $36 \mathrm{~h} \mathrm{EC}$

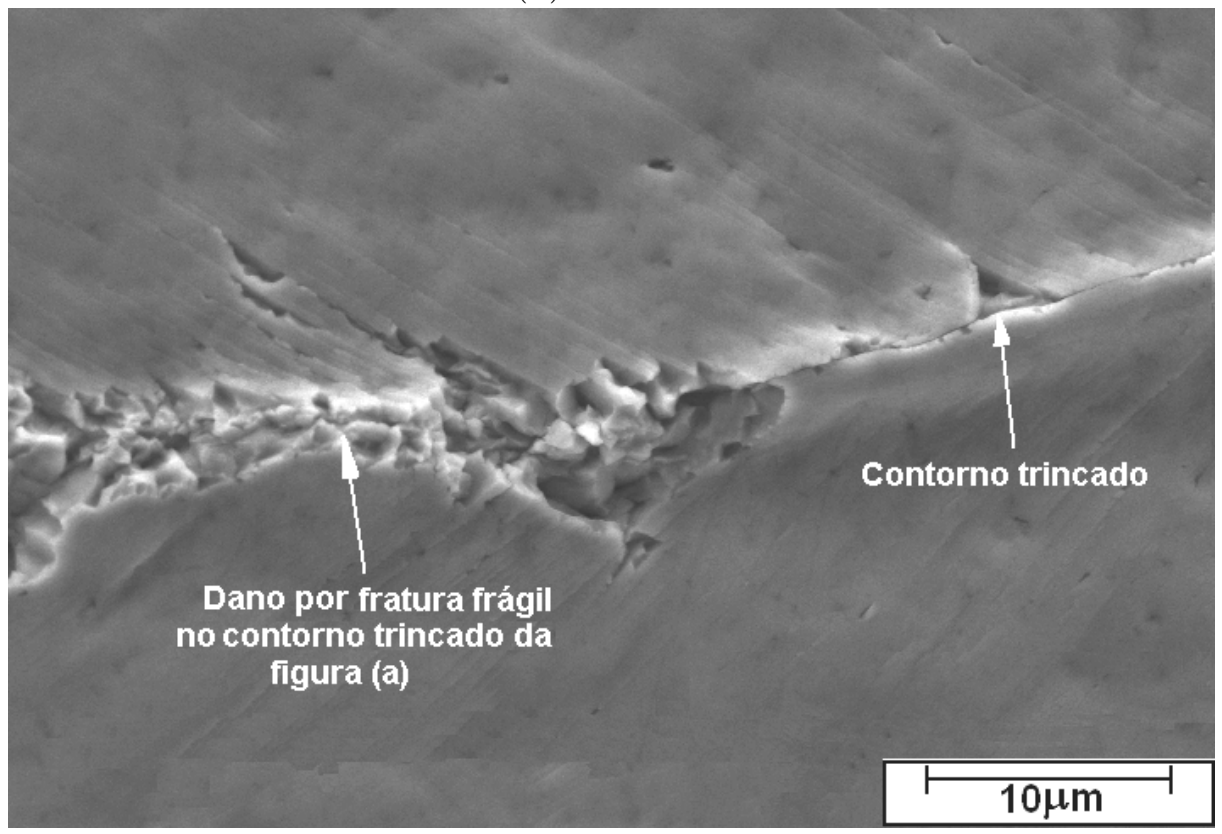

(b) $64 \mathrm{~h} \mathrm{EC}$

Figura 5.32: Micrografias MEV para o aço 318HTGN+Plas onde se apresenta: (a) o início e (b) a propagação do dano em contornos altamente resistentes ao desgaste EC.

\subsubsection{Aço 304L solubilizado e nitretado a plasma (304LSol+Plas. amostra 6)}

Para o aço 304L solubilizado, com formação de austenita expandida por tratamento de nitretação a plasma, são apresentadas micrografias nas figuras 5.34 (a) e (b) para 0,5 horas de ensaio de desgaste EC. Estas micrografias mostram o comportamento deste material frente ao desgaste por EC no período inicial do dano. 


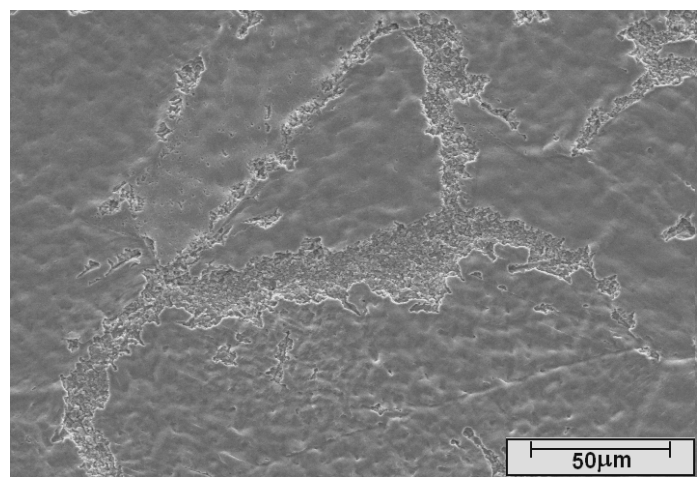

(a)

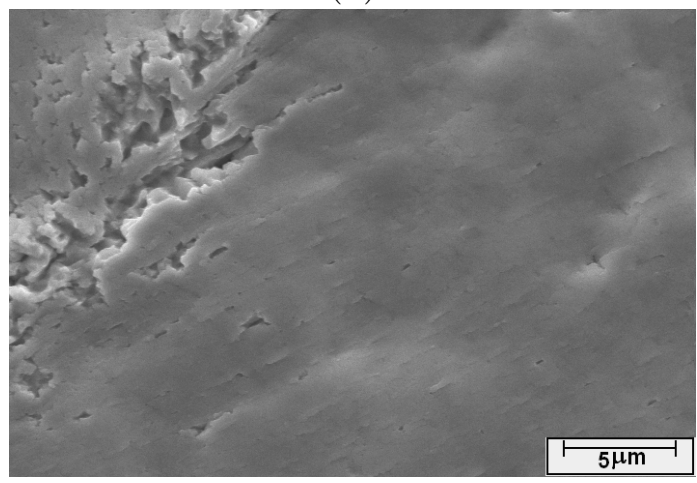

(c)

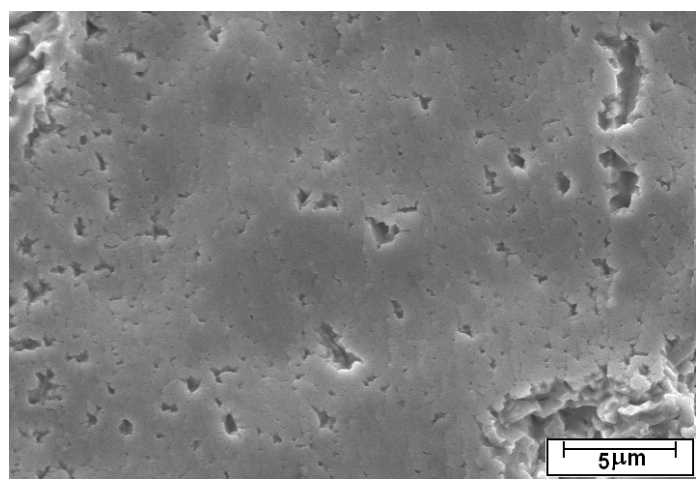

(b)

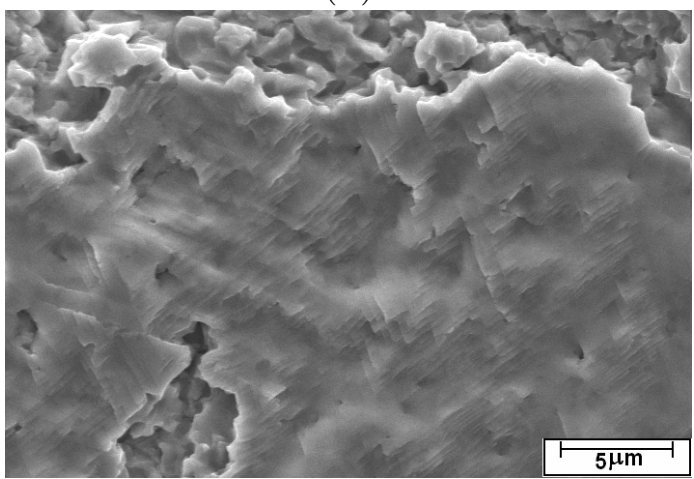

(d)

Figura 5.33: Micrografias MEV onde se visualizam regiões que mostram o dano por EC no aço 318HTGN+Plas para tempos de ensaio avançados (100h).

(a) contornos de grão, interior do grão e (c) e (d) bandas de escorregamento.

Observando a micrografia da figura 5.34 (a), nota-se que as primeiras evidências de dano por EC, se apresentam principalmente em contornos de grão e em menor proporção no interior destes, como pode ser verificado da figura 5.34 (b). Nesta última micrografia percebe-se que a camada de austenita expandida falhou em vários pontos, dando lugar à formação de crateras, expondo o substrato de baixa dureza. Estas crateras se tornaram sítios preferenciais para o ataque da EC para tempos maiores do ensaio. Na figura 5.34(a) observa-se, também, uma mudança na rugosidade da superfície causada por deformação plástica, que pode ser verificada pela formação de protuberâncias, tanto nos contornos como no interior dos grãos. A deformação plástica promove a formação de bandas de deslizamento, onde a ativação simultânea de vários sistemas de deslizamento leva à formação de um padrão de degraus como o observado na figura 5.34 (b). Essas bandas de deslizamento são também regiões preferenciais para o início do dano.

A camada de austenita expandida obtida sobre o aço ligado com 0,9\% em massa de $\mathrm{N}$ apresentou uma resistência acentuadamente superior ao dano por EC quando comparada com a camada de austenita expandida sob o aço sem nitrogênio, embora, ambas camadas apresentaram espessura similar e mesma dureza (1700 HV0,005). 


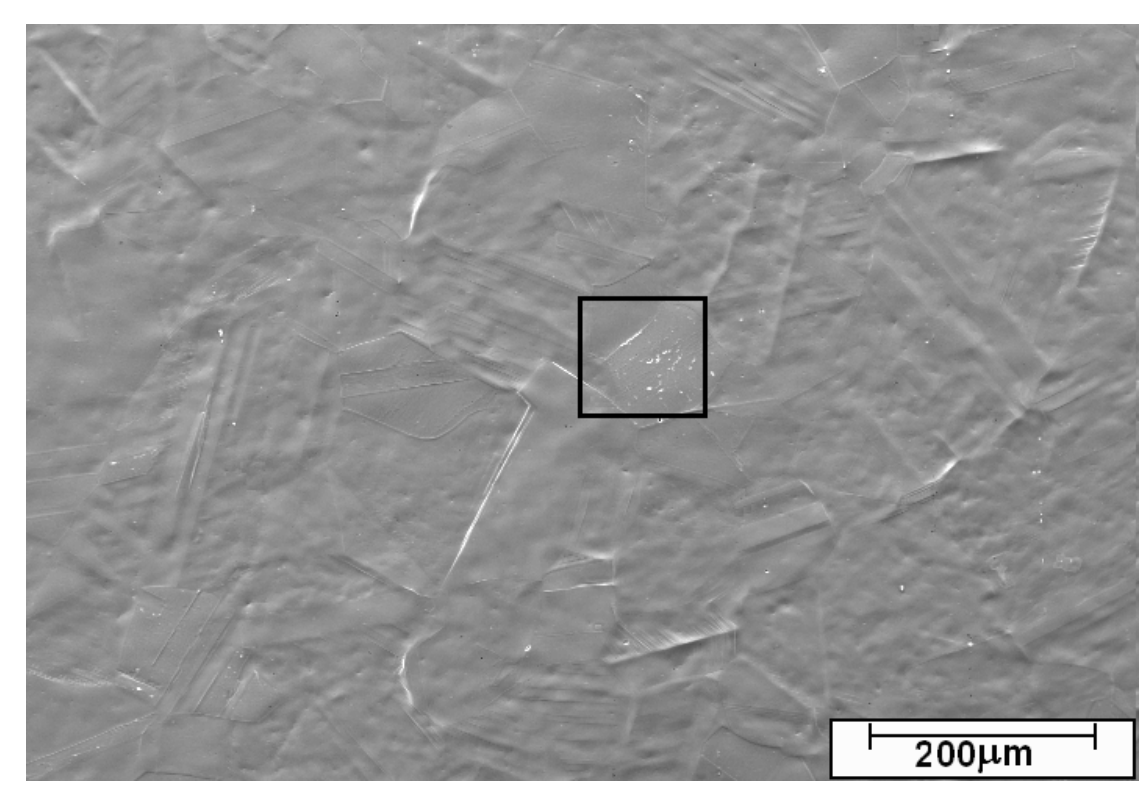

(a)

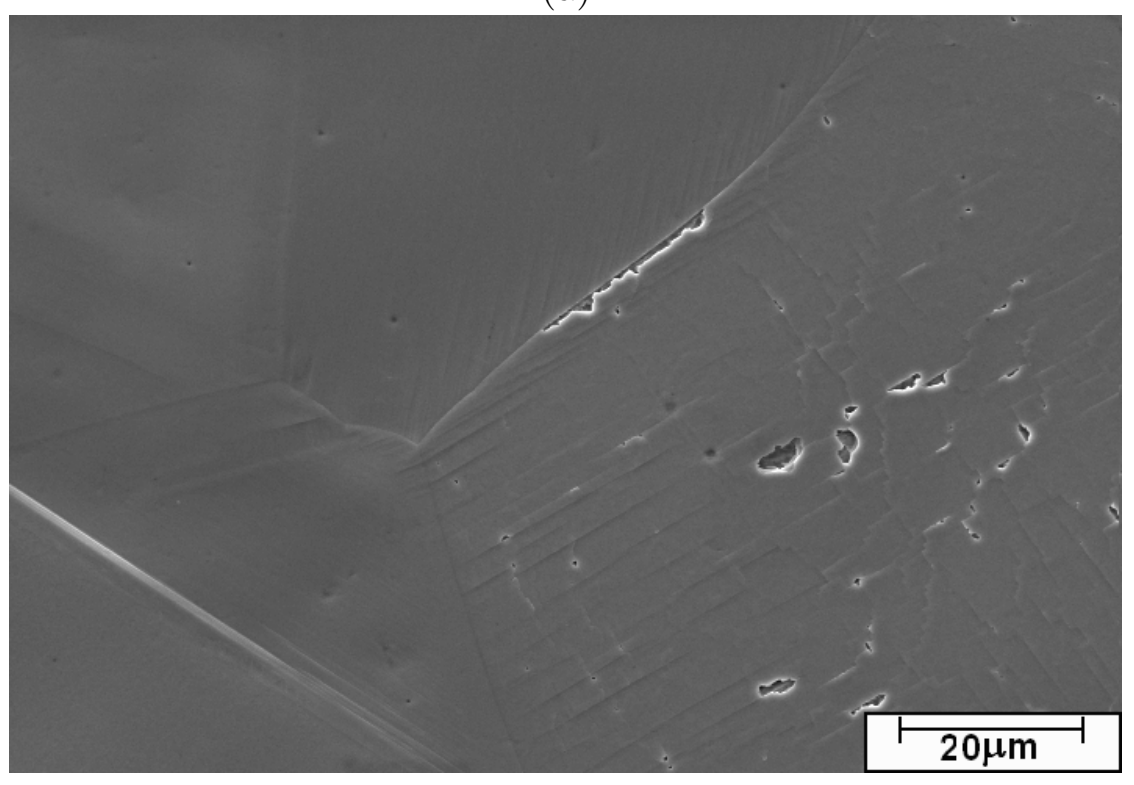

(b)

Figura 5.34: Micrografias MEV onde se apresentam os primeiros sintomas de desgaste no aço 304LSol+Plas ensaiado a EC por 0,5 horas: (a) micrografia geral e (b) micrografia do detalhe mostrado na figura (a).

A grande diferença na resistência à deterioração entre os dois materiais nitretados a plasma, induzida por cavitação, pode ser atribuída principalmente, ao elevado gradiente de propriedades entre a camada de austenita expandida e o núcleo do aço 304L de baixo teor de nitrogênio. Adicionalmente a capacidade de encruamento deste núcleo sem $\mathrm{N}$ é muito baixa. Esses dois fatores contribuem para a falta de sustentação mecânica da camada de austenita expandida.

Nas figuras 5.35 (a) a (c) são apresentadas micrografias para o aço 304LSol+Plas, onde se mostra o avanço do dano EC para 3, 6 e 12 horas de ensaio de desgaste por EC. Nas micrografias da figura 5.35 (d) a (f) são apresentadas 
em detalhe as regiões mostradas nas micrografias (a) a (c), respectivamente.

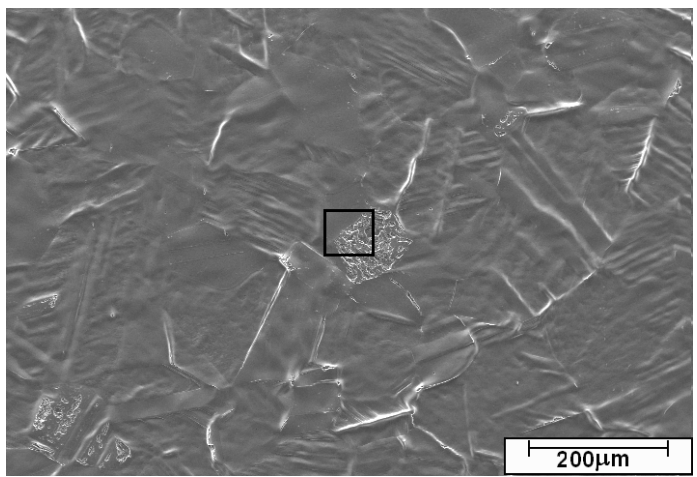

(a) $3 \mathrm{~h} \mathrm{EC}$

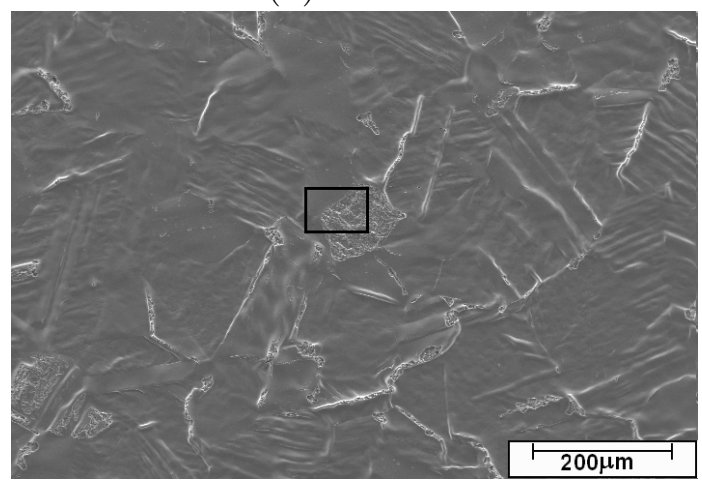

(b) $6 \mathrm{~h} \mathrm{EC}$

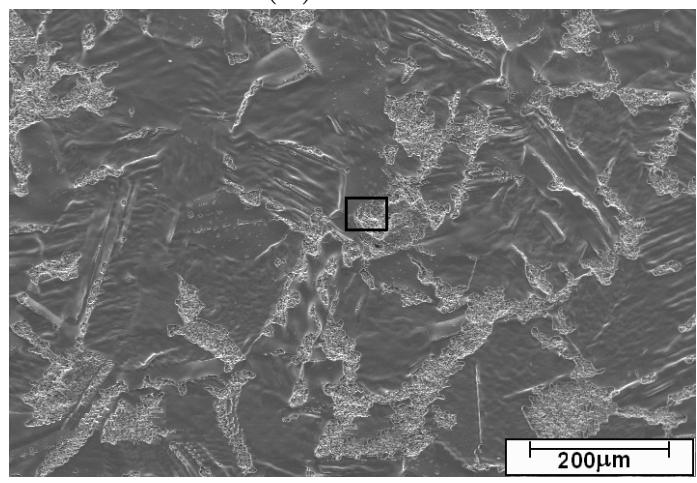

(c) $12 \mathrm{~h} \mathrm{EC}$

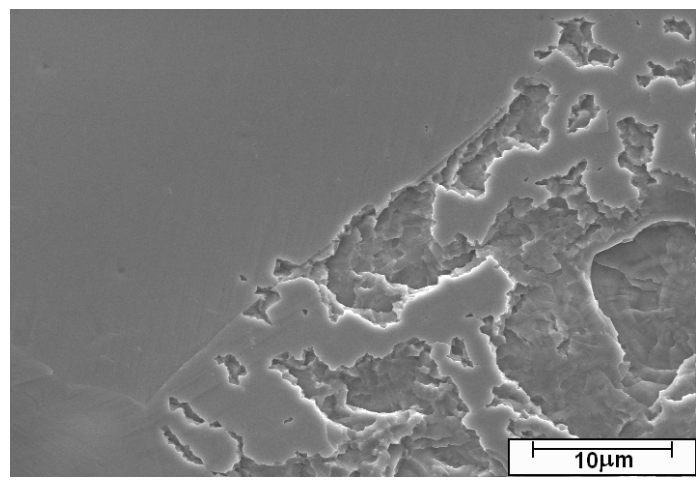

(d) $3 \mathrm{~h} \mathrm{EC}$

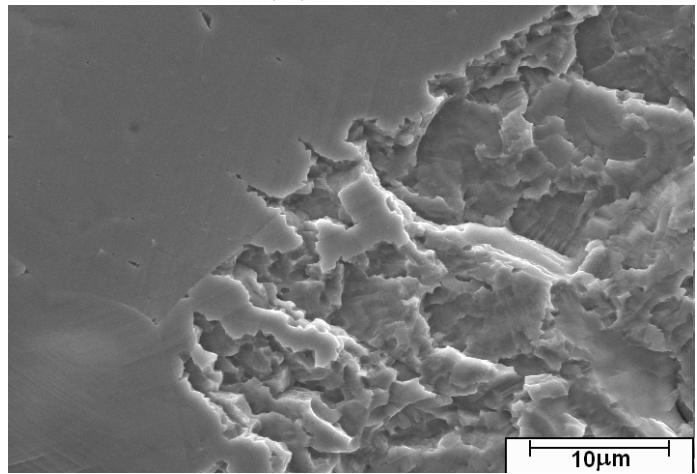

(e) $6 \mathrm{~h} \mathrm{EC}$

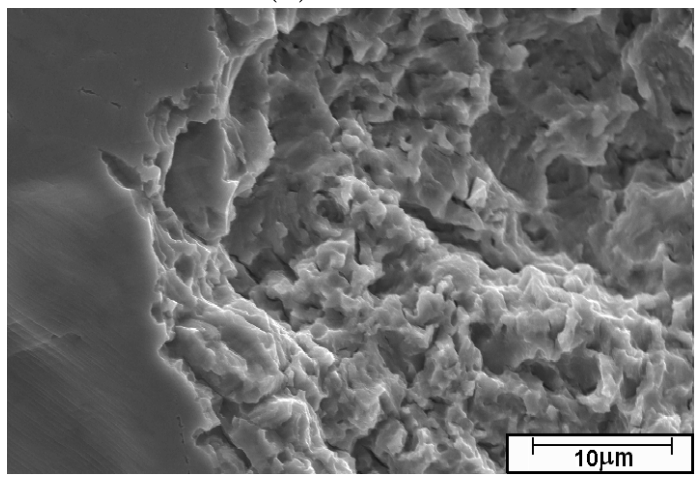

(f) $12 \mathrm{~h} \mathrm{EC}$

Figura 5.35: Micrografias MEV onde se apresenta o avanço do dano por EC no aço 304LSol+Plas: (a), (b) e (c) micrografias para 3, 6 e 12 horas de ensaio respectivamente, e (d), (e) e (f) detalhes dos destaques mostrados nas figuras (a), (b) e (c) respectivamente.

Na sequência de micrografias (a) a (c) da figura 5.35, observa-se que o dano, para longos tempos de ensaio, afeta praticamente a maioria de contornos de grão, porém o interior deles ainda continua visivelmente conservado. Isto evidenciou uma forte aderência da camada de austenita expandida ao substrato. Nota-se, também, das figuras 5.35 (c) a (f) que nas regiões dos grãos onde a camada de austenita expandida foi danificada, esta se degrada rapidamente na direção ao substrato. A elevada taxa de desgaste das amostras do aço 304LSol+Plas devese à baixa resistência ao desgaste do substrato e não da camada de austenita expandida, como se pode observar nas micrografias (d) e (f) da figura 5.35, onde 
há regiões da camada de austenita expandida muito conservadas e regiões no substrato muito danificadas.

\subsubsection{Materiais de comparação (tipo 5)}

\subsubsection{Aço 304L solubilizado (304LSol, amostra 7)}

Nas micrografias da figura 5.36 (a) e (b) se apresenta, para o aço 304L no estado solubilizado, o comportamento da superfície frente ao desgaste EC no período inicial, para os primeiros 20 minutos de ensaio.

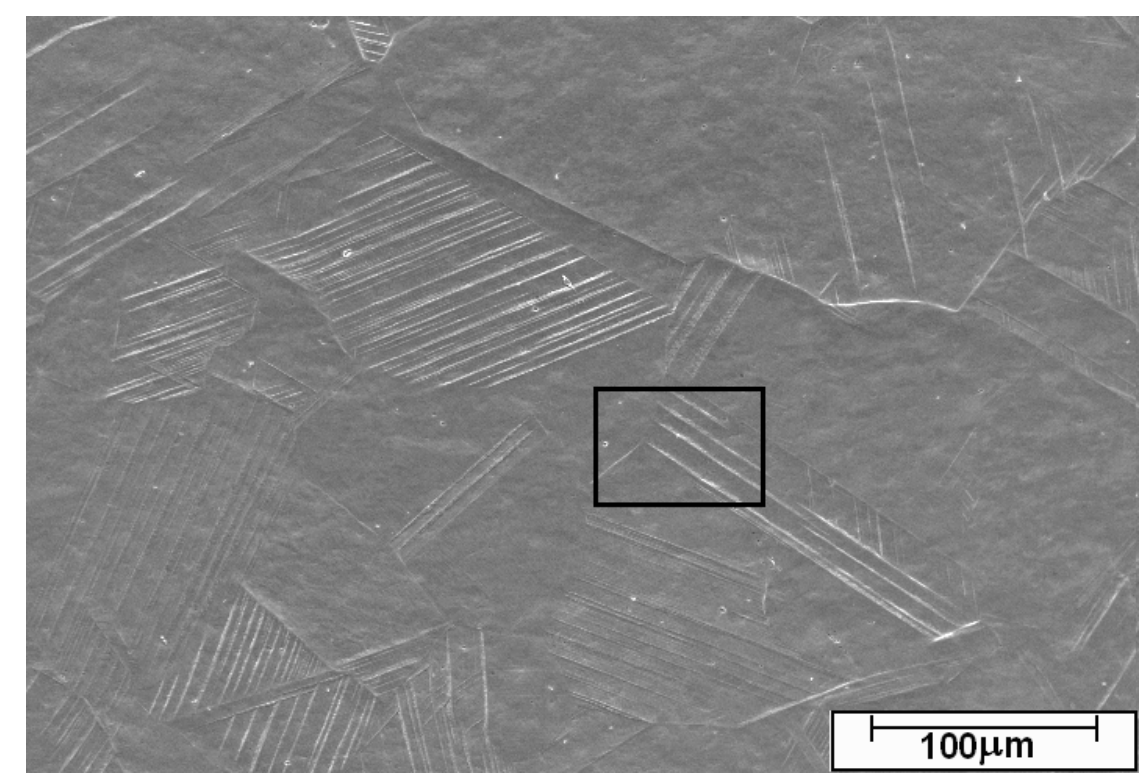

(a)

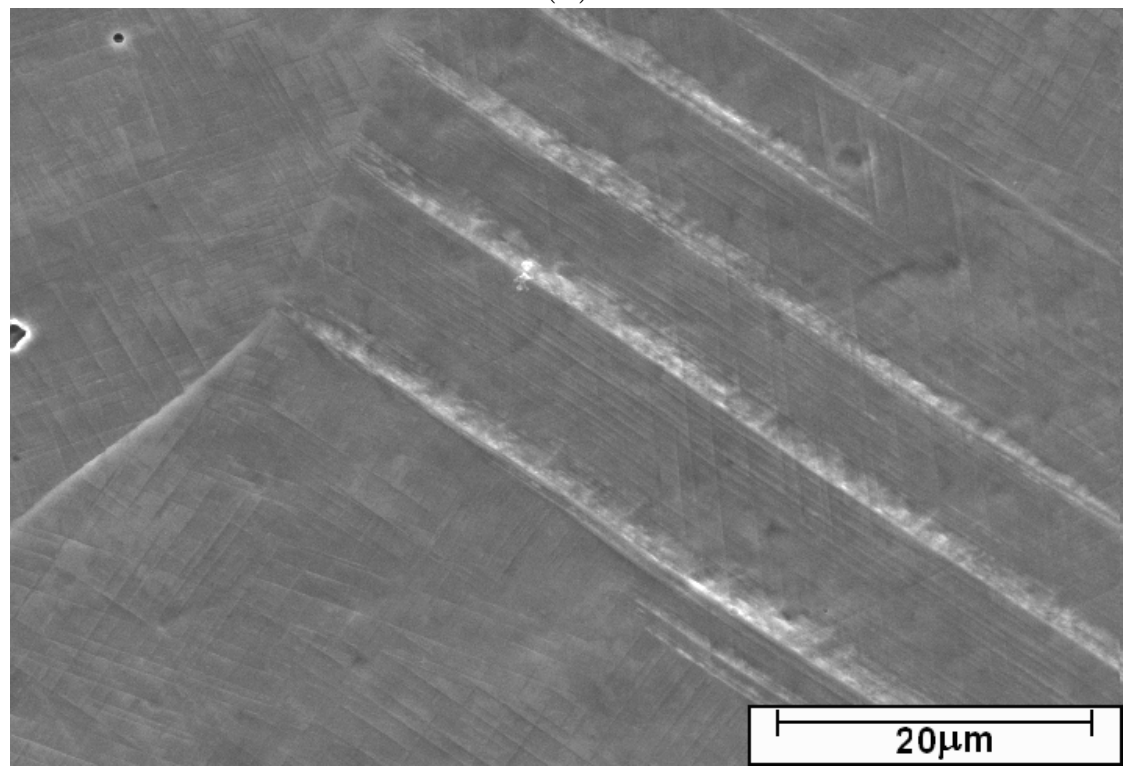

(b)

Figura 5.36: Micrografias MEV apresentando os primeiros sintomas de dano durante o período de incubação no aço 304LSol: (a) aspecto geral da superfície, (b) detalhe da figura (a). 
Nas micrografias apresentadas na figura 5.36 (a) e (b) observa-se que as primeiras evidências de dano ocorrem por deformação plástica o que favorece o surgimento de bandas de escorregamento no interior dos grãos, algumas delas bastante espessas. Outras evidências de dano visíveis na superfície são a presença de pites e protuberâncias, defeitos que acompanham as bandas de escorregamento grosseiras. De modo geral, observa-se que assim como ocorre com os materiais considerados até aqui, a deformação não é homogênea na superfície, concentrando-se mais em alguns grãos e contornos de grão do que em outros.

Nas micrografias apresentadas nas figuras 5.36 (a) a (f), para 1,5; 3 e 6 horas de ensaio, para etapas de desgaste a partir do tempo de incubação, que é de aproximadamente 1,5 horas, e após a superfície ter sofrido intensa deformação plástica, observa-se que a presença de fratura frágil em contornos de grão, protrusões em contornos localizados entre grãos que têm comportamentos diferentes frente á deformação plástica e aumento do relevo são os mecanismos que levam a uma rápida deterioração da superfície do aço.

Nas micrografias apresentadas nas figuras 5.37 (a) e (d), observa-se que o início do destacamento de material ocorre principalmente nos contornos de grão, por esgotamento de capacidade de deformação plástica, quando a superfície é atingida por ondas de choque e as tensões decorrentes da cavitação ultrapassam a tenacidade à fratura do material. Nas micrografias apresentadas nas figuras 5.37 (b) e (e), observa-se que as bandas de escorregamento espessas constituem também regiões preferenciais para o início e avanço do desgaste. Nesta fase, os mecanismos de deformação plástica e fratura frágil atuam de forma competitiva. Finalmente nas micrografias apresentadas nas figuras 5.37 (c) e (f), observa-se que o dano da superfície é generalizado e que a fratura frágil é o principal mecanismo de desgaste.

A diferença de orientação cristalográfica de cada um dos grãos, com relação à dos seus vizinhos, afeta diretamente o valor da tensão de cisalhamento crítica responsável pela deformação; esta é uma das possíveis hipóteses que explicam a heterogeneidade da deformação plástica sofrida por cada um dos grãos.

\subsubsection{Superliga Stellite-6 (Stellite-6, amostra 8):}

As micrografias apresentadas na figura 5.38 (a) e (b) mostram, para a superliga Stellite-6, material que foi utilizado como comparação devido a sua alta resistência ao desgaste EC, o desenvolvimento do dano durante as primeiras etapas do desgaste EC. 


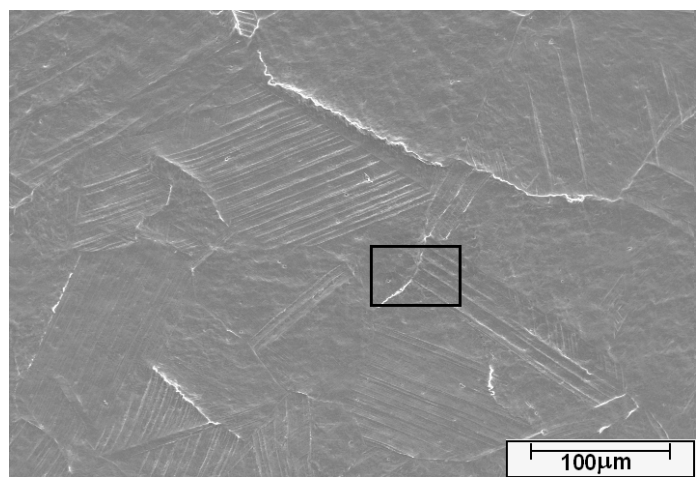

(a) $1.5 \mathrm{~h} \mathrm{Ec}$

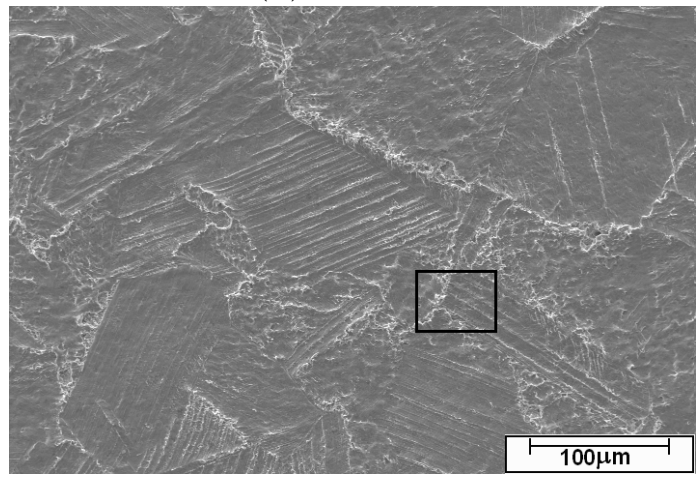

(b) $3 \mathrm{~h}$ EC

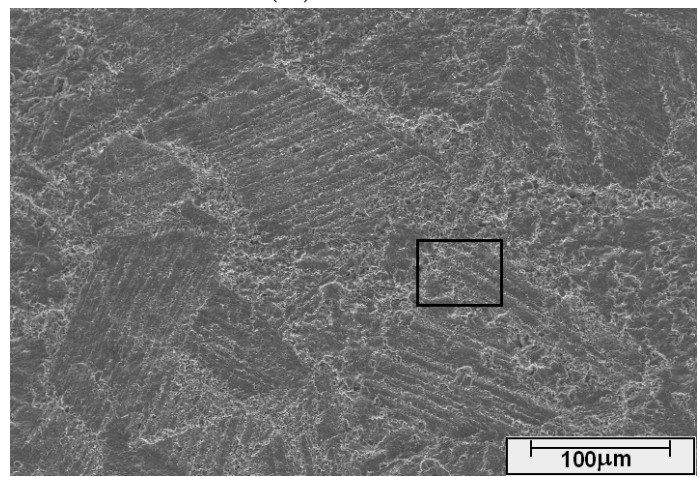

(c) $6 \mathrm{~h} \mathrm{EC}$

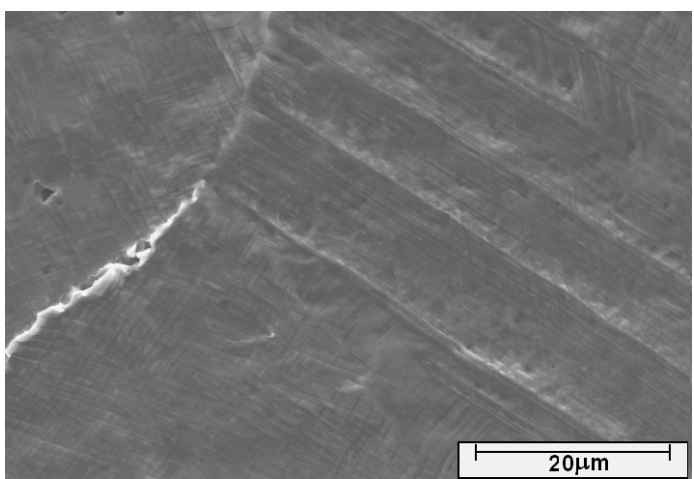

(d) $1.5 \mathrm{~h} \mathrm{EC}$

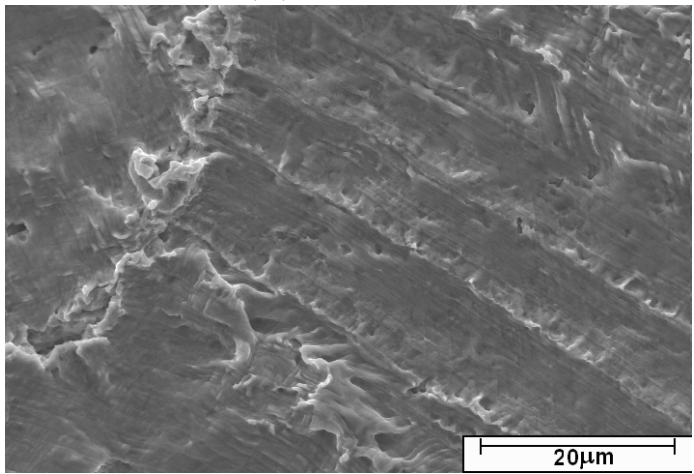

(e) $3 \mathrm{~h}$ EC

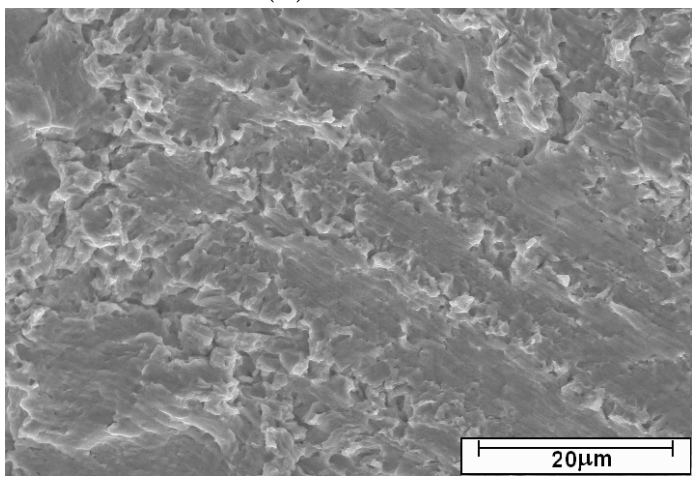

(f) $6 \mathrm{~h} \mathrm{EC}$

Figura 5.37: Micrografias MEV onde se apresenta a evolução do processo de desgaste no aço 304LSol em função do tempo de ensaio de desgaste EC para: (a) 1.5, (b) 3 e (c) 6 horas. (d), (e) e (f) são detalhes de regiões nas superfícies (a), (b) e (c) respectivamente.

Para 4 horas de ensaio não foi observada perda de massa, a qual começou a ser mensurável para tempos maiores que 16 horas.

Na figura 5.38 (a) nota-se que para as primeiras etapas do desgaste, a liga Stellite-6 apresenta a matriz com poucas evidências de dano, no entanto observase uma forte quebra dos seus carbonetos, como pode ser verificado na micrografia apresentada na figura 5.39. O sítio preferencial para o início do dano é a interface matriz-carboneto; nestas regiões os carbonetos foram seletivamente arrancados como se pode observar na figura 5.38 (b). Na mesma figura, em sua parte superior, podem-se observar grãos com presença de bandas de escorregamento, 


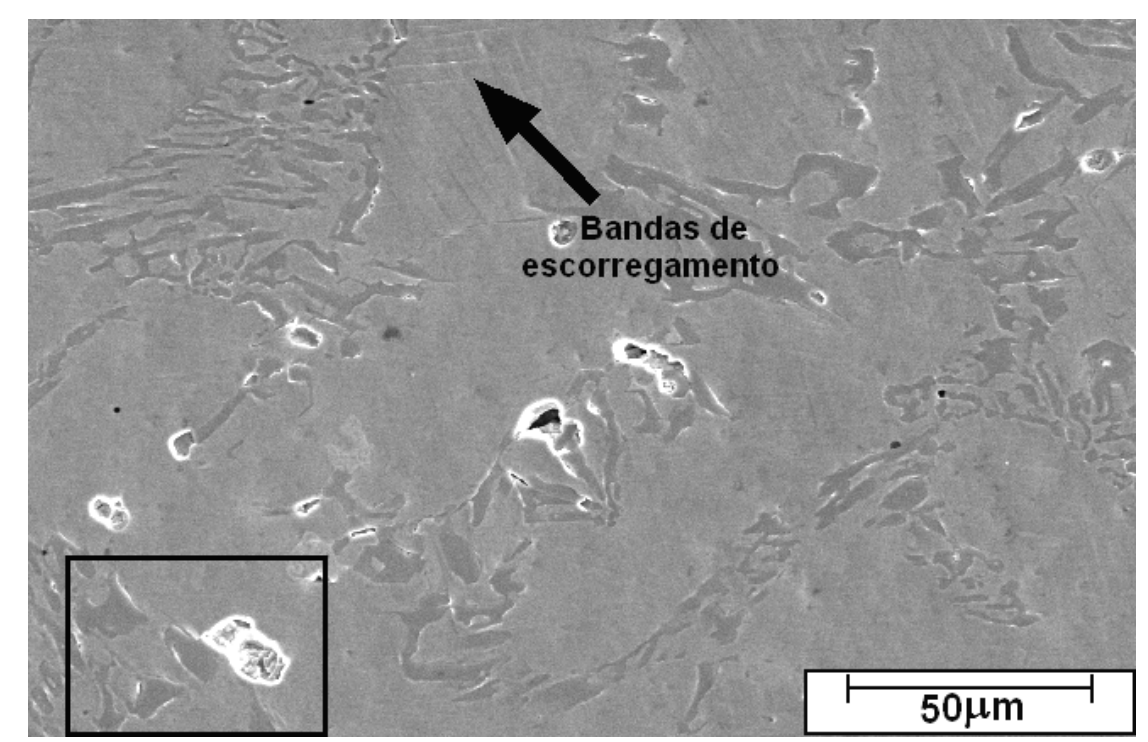

(a)

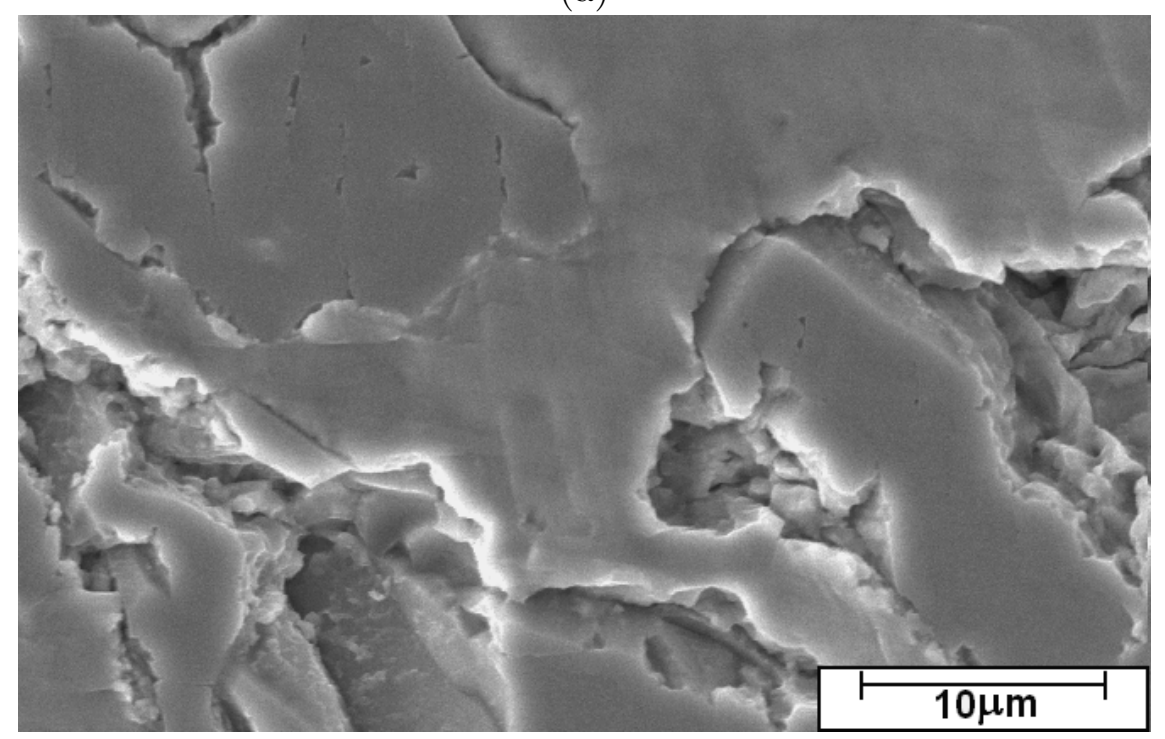

(b)

Figura 5.38: Micrografias MEV onde se apresentam os primeiros sintomas de dano na superliga Stellite-6 durante o período de incubação do desgaste por EC para 4 horas de ensaio.

como consequência da deformação plástica.

Na micrografia apresentada na figura 5.39 observa-se como os carbonetos são quebrados, possivelmente, devido à ação das ondas de choque decorrentes dos ensaios de EC, afetando sua integridade até profundidades consideráveis para dentro do substrato.

As micrografias apresentadas nas figuras 5.40 (a) a (c) mostram o avanço do dano por EC para tempos de ensaio de 16, 36 e 49 horas para a superliga Stellite-6.

Seja qual for o mecanismo de dano dominante na superliga de Stellite-6, o destacamento dos carbonetos é quem limita a resistência ao desgaste desta liga, 


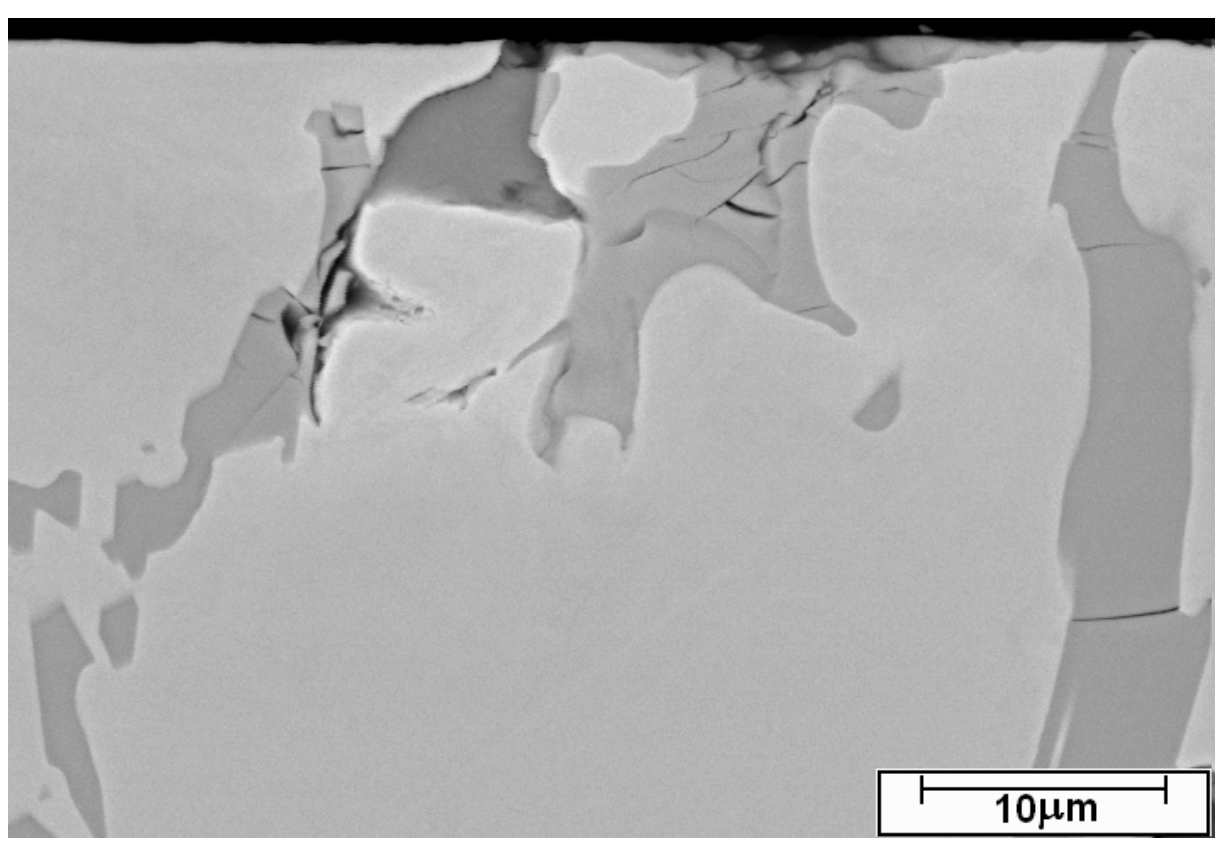

Figura 5.39: Micrografia MEV da seção transversal da amostra de Stellite-6 mostrando quebra de carbonetos após ter sido ensaiada em EC por 64 horas.

como se verifica nas micrografias apresentadas nas figuras 5.40 (b) e (e). Embora também tenha ocorrido destacamento de material das bandas de escorregamento, este se apresentou em proporção mínima, como se vê na figura 5.40 (e). Segundo Cuppari (CUPPARI; SOUZA; SINATORA, 2005) quando carbonetos grosseiros estão presentes num material submetido a EC, tais partículas ficam submetidas a maior concentração de tensões, levando ao seu destacamento prematuro, o que dá suporte à observação do comportamento aparentemente frágil dos carbonetos frente ao desgaste por EC.

Considerando tempos maiores de ensaio e que os carbonetos foram todos arrancados da superfície do material, a matriz começa uma rápida deterioração com formação de grandes vazios que aumentam dramaticamente a perda de massa, onde o mecanismo de desgaste principal é fratura frágil como se pode observar nas micrografias (c) e (f) da figuras 5.40 .

\subsection{Relação entre desgaste por EC com aspectos cristalográficos}

A seguir serão discutidas algumas relações encontradas em vários dos materiais utilizados neste estudo entre o seu desempenho frente ao desgaste EC e algumas características cristalográficas como a orientação cristalográfica grão a grão (meso-textura); o tipo de contornos de grão (CSL e Não CSL) e a atuação de tensões presentes ao nível dos grãos segundo a teoria de Taylor. Estas relações 


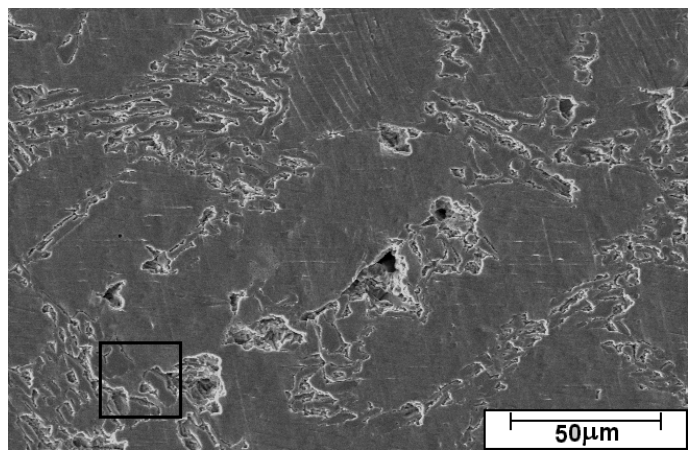

(a) $16 \mathrm{~h} \mathrm{EC}$

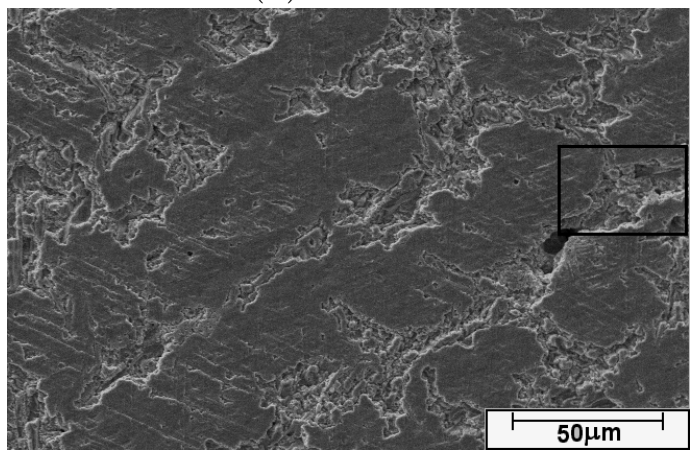

(b) $36 \mathrm{~h} \mathrm{EC}$

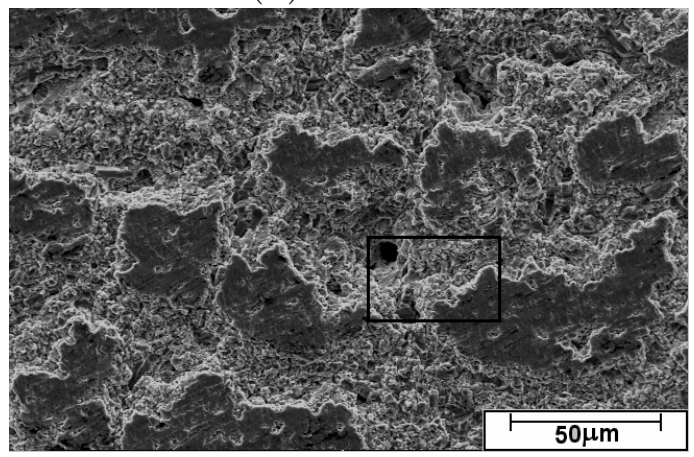

(c) $49 \mathrm{~h} \mathrm{EC}$

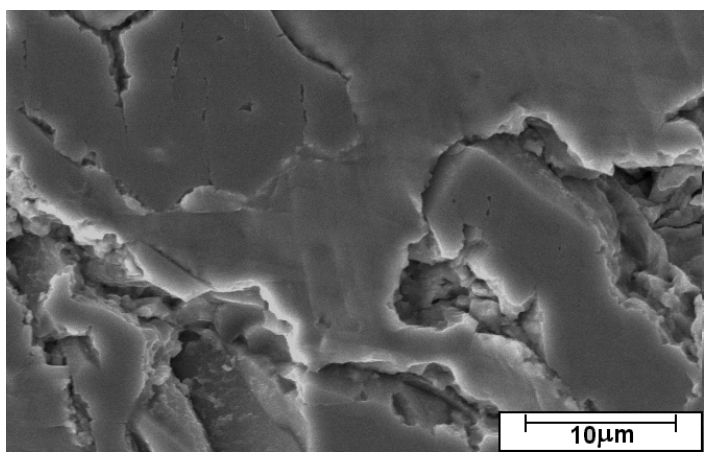

(d) $16 \mathrm{~h} \mathrm{EC}$

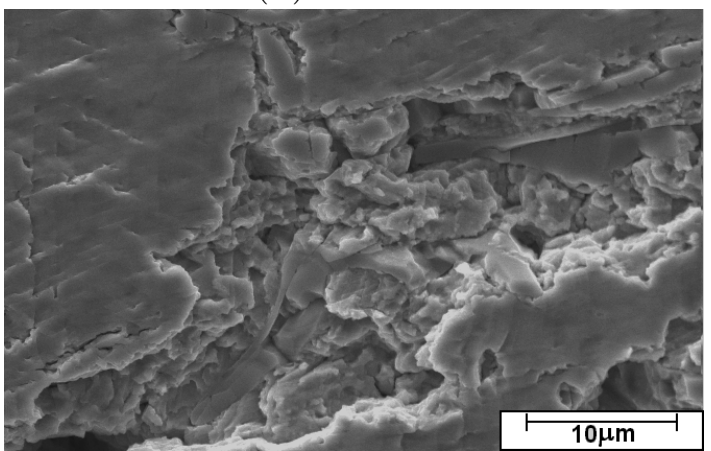

(e) $36 \mathrm{~h} \mathrm{EC}$

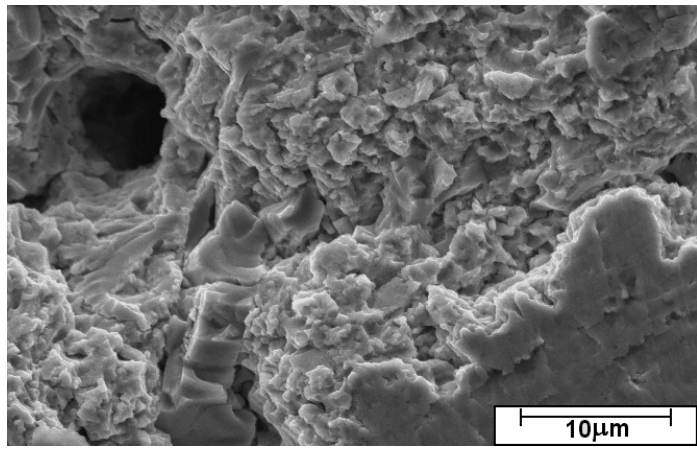

(f) $49 \mathrm{~h} \mathrm{EC}$

Figura 5.40: Micrografias MEV onde se apresenta a evolução do processo de dano em etapas avançadas do desgaste por EC no Stellite-6: (a), (b) e (c) são micrografias correspondentes a 16, 36 e 49 horas de ensaio de desgaste EC respectivamente; (d), (e) e (f) são detalhes de regiões nas superfícies (a), (b) e (c) respectivamente.

foram analisadas para as amostras contendo $0,9 \%$ de $\mathrm{N}$ sem encruamento.

\subsubsection{Relação entre desgaste EC, orientação crista- lográfica e FT}

Na figura 5.41 (a) vê-se o mapa de distribuição de orientações cristalográficas obtido por EBSD da superfície do aço 318HTGN+Sol, antes de ser submetido a ensaios de desgaste por EC.

Na figura 5.41 (b), usando um critério meramente visual, é possível observar quais regiões da Figura 5.41 (a) apresentam os primeiros indícios de dano por EC 
e quais regiões permanecem conservadas para 4 horas de ensaio de desgaste EC. Na figura 5.41 (c) foram destacados com linhas verdes os grãos da Figura 5.41 (b) que ficaram mais conservados. Já na figura 5.41 (d) é apresentado um mapa OIM da mesma região onde só aparecem os grãos com orientação cristalográfica 101 paralela à superfície cavitada, que visualmente se apresentaram mais conservados.

Na figura 5.42 apresenta a mesma sequência de mapas e micrografias da região analisada na figura 5.41, porém para 64 horas de ensaio de desgaste EC.

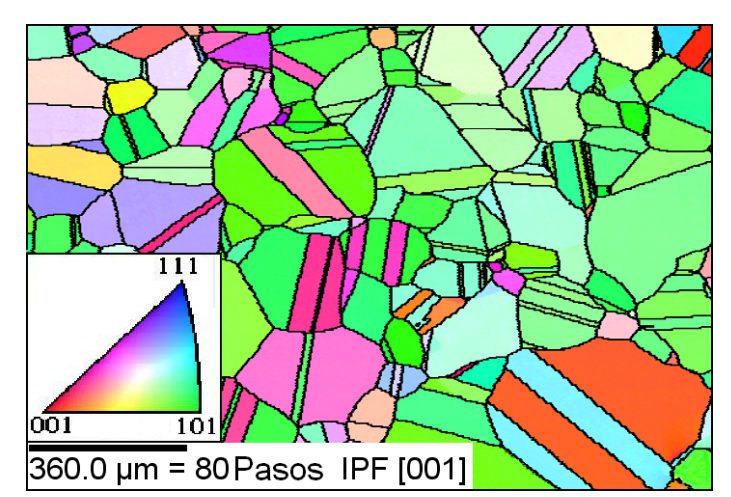

(a)

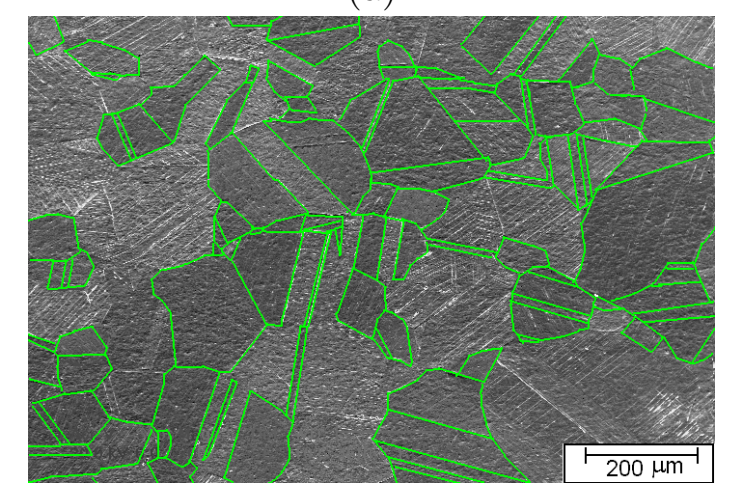

(c)

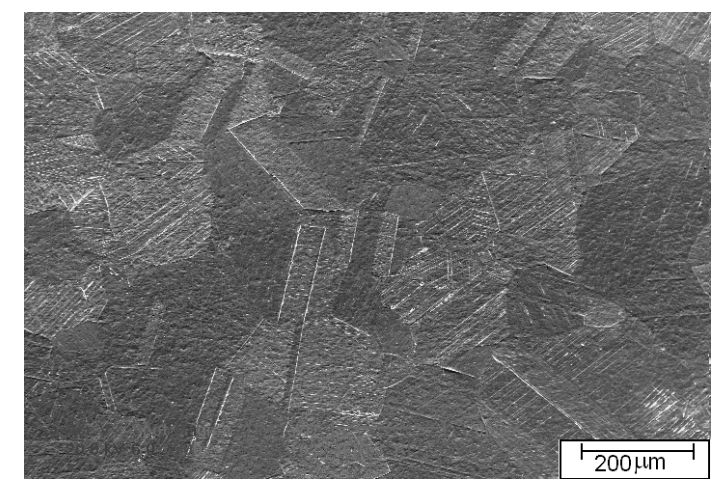

(b)

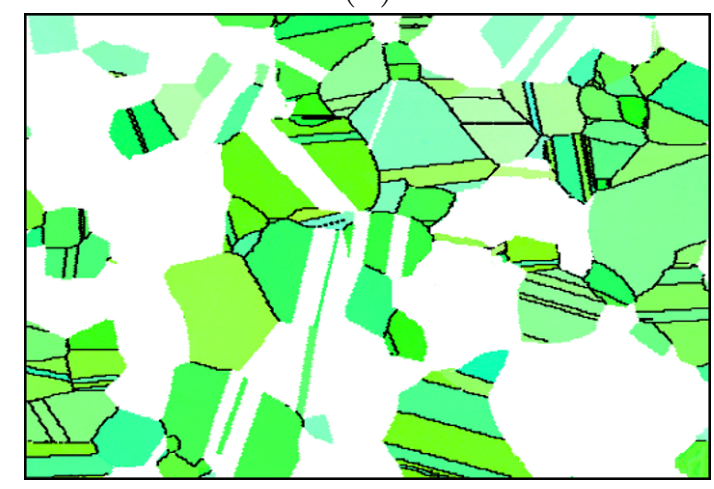

(d)

Figura 5.41: Para o aço 318HTGN+Sol, após 4 horas de ensaio de desgaste EC: (a) mapa OIM, (b) micrografia MEV correspondente com o mapa (a), (c) destaque dos grãos mais conservados segundo a micrografia (b), (d) mapa OIM de grãos mais conservados correspondente com a figura (b) e (c).

No mapa EBSD mostrado na figura 5.41 (a) observa-se que a grande maioria dos grãos apresenta uma orientação cristalográfica 101 paralela à superfície, e são destacados nas figuras 5.41 (c) e (d). Na micrografia da figura 5.41 (b), observase que os grãos com orientação cristalográfica 101 paralela à superfície têm um comportamento diferenciado frente ao desgaste, apresentando a sua superfície mais conservada do que grãos com outro tipo de orientação cristalográfica. A mesma situação pode ser verificada para 64 horas de ensaio, em que uma elevada porção de grãos que têm suas superfícies pouco deterioradas (regiões mais escuras destacadas na micrografia da figura 5.42 (c)), possuem orientação cristalográfica 


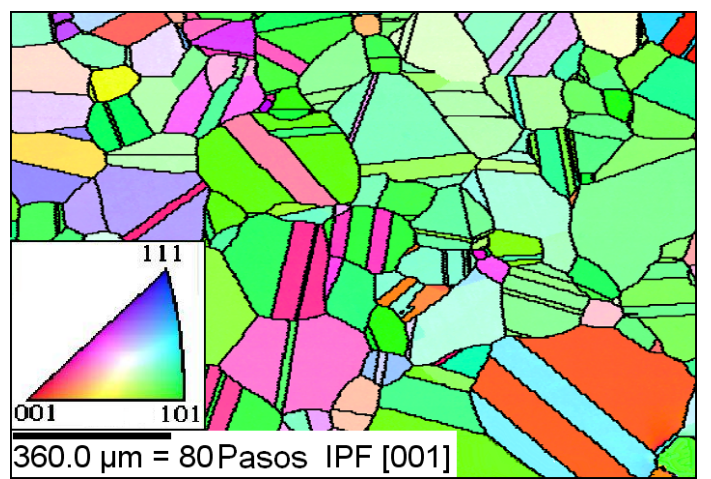

(a)

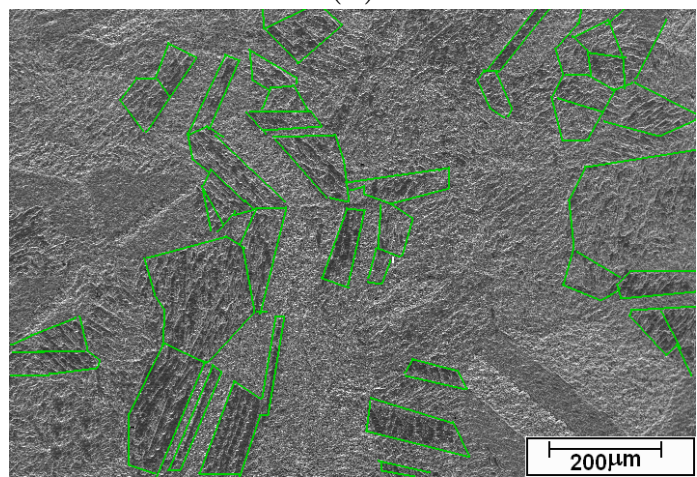

(c)

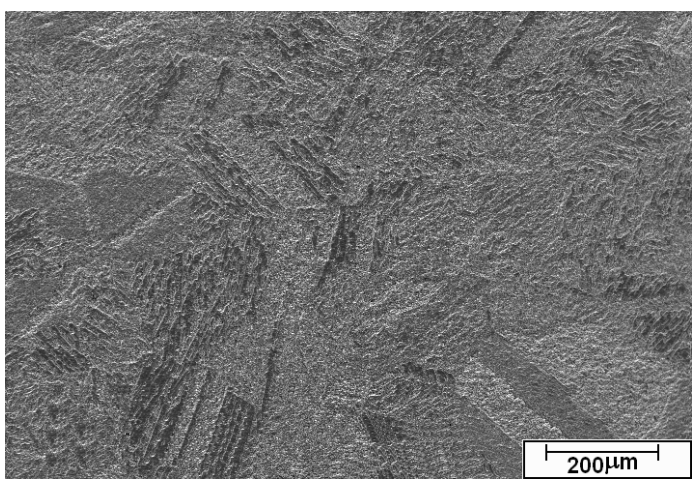

(b)

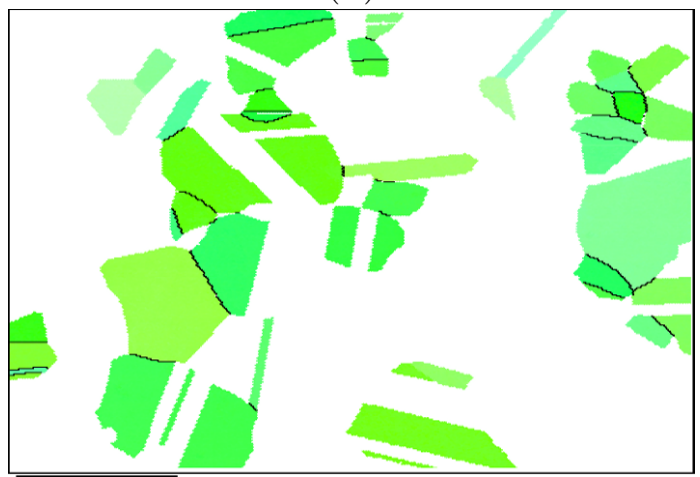

(d)

Figura 5.42: Para o aço 318HTGN+Sol após 64 horas de ensaio de desgaste EC: (a) mapa OIM, (b) micrografia MEV correspondente com o mapa da figura (a), (c) destaque dos grãos mais conservados segundo a micrografia (b), (d) mapa OIM de grãos mais conservados correspondente com a figura (b) e (c).

101 paralela à superfície.

A maior resistência ao desgaste de grãos com orientação cristalográfica 101 paralela à superfície pode ser atribuída à forma como as tensões provenientes das ondas de choque e micro-jatos, após a implosão de bolhas de cavitação, afetam estes grãos. Para tais orientações, é altamente provável que a tensão projetada crítica para induzir a deformação plástica seja menor que a correspondente para outras orientações cristalográficas

Para verificar tanto a variação da tensão cisalhante crítica quanto a sua dependência com a orientação cristalográfica grão a grão, foi calculado o Fator de Taylor - FT para uma subregião na área desgastada por cavitação, como mostrado nas figuras 5.43 (a) a (d). Neste caso foi considerado que as tensões que atuam na superfície do material durante o ensaio de desgaste EC, são de compressão na direção normal à superfície cavitada. Este tipo de tensão representa (embora de forma simplificada), a atuação de uma onda de choque ou um micro-jato quando atinge uma superfície sólida. Este modelo já tinha sido discutido por autores como Hammitt e Mathias e Poll (MATHIAS; POHL, 1991; HAMMITT, 1966), que comparam o efeito das tensões decorrentes das ondas de choque e microjatos, 
quando atingem uma superfície sólida, com o efeito provocado por jateamento de superfícies com granalha (shot peening), em que os mecanismos de deformação são muito similares. Assim com ajuda do programa TSL/OIM foi calculado o FT assumindo a ocorrência de uma tensão de compressão, normal à superfície cavitada como mostrado na figura 5.43 (d).

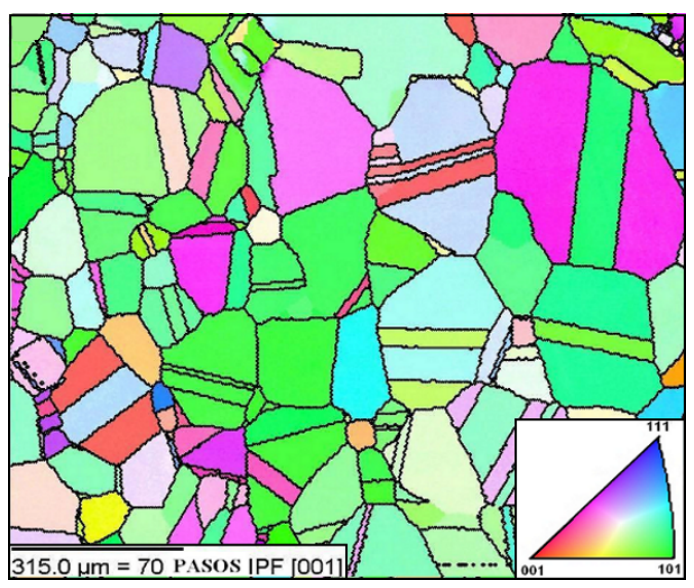

(a)

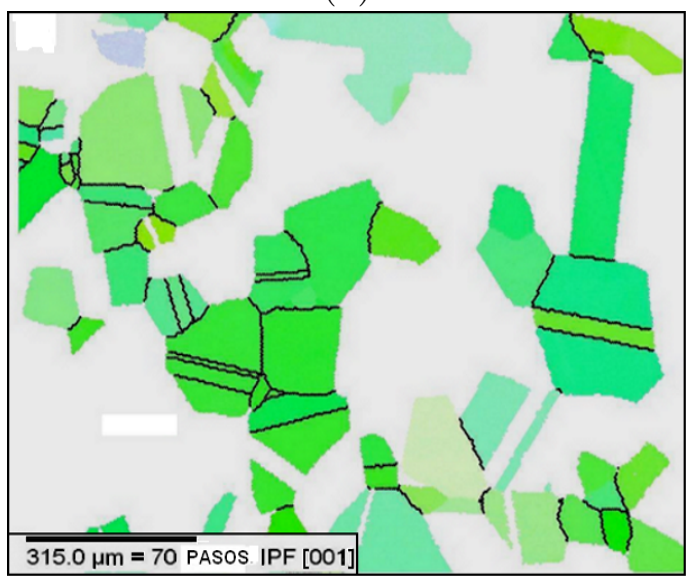

(c)

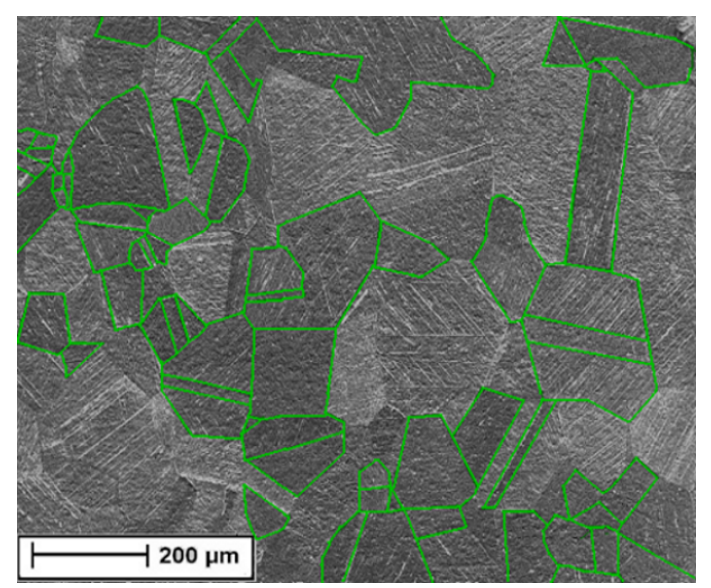

(b)

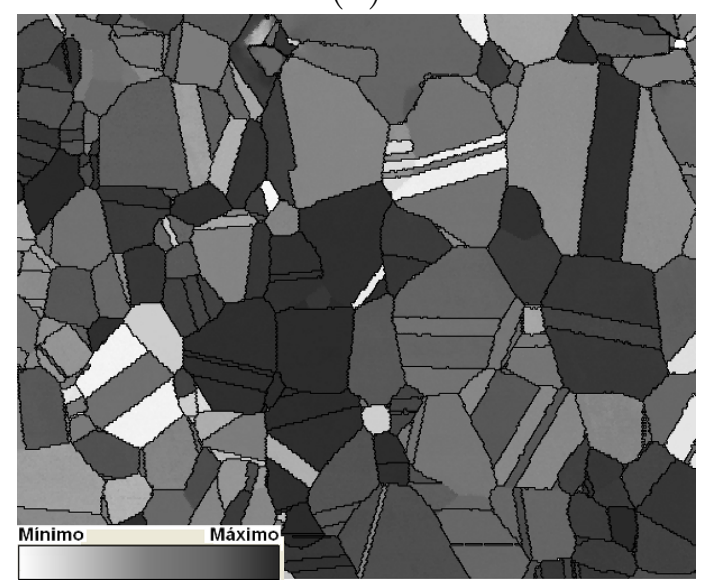

(d)

Figura 5.43: Para o aço 318HTGN+Sol: (a) mapa de distribuição de orientações cristalográficas OIM, (b) micrografia MEV onde se destacam grãos com orientação 101 paralela à superfície, (c) mapa de distribuição de orientações cristalográficas OIM mostrando grãos isolados com orientação 101 destacados em (b), (d) mapa de FT para tensão de compressão normal à superfície cavitada

Observando o mapa do FT da figura 5.43 (d), grãos com tonalidade cinza claro, indicam que o FT é baixo e possuem uma orientação cristalográfica favorável para escoar plasticamente. O contrário ocorre com os grãos de tonalidade cinza escura, onde o FT é alto, indicando que a sua orientação cristalográfica não é favorável para deformar plasticamente.

De acordo com o observado nos mapas e micrografias apresentados na figura 5.43 , para o aço $318 \mathrm{HTGN}+\mathrm{Lam}+$ Sol, ensaiado por 64 horas à EC, é possível afirmar que as mesmas hipóteses discutidas para o comportamento diferenciado 
de grãos com orientação cristalográfica 101 paralela à superfície para o aço 318HTGN+Sol, são semelhantes e por isso não serão discutidas novamente.

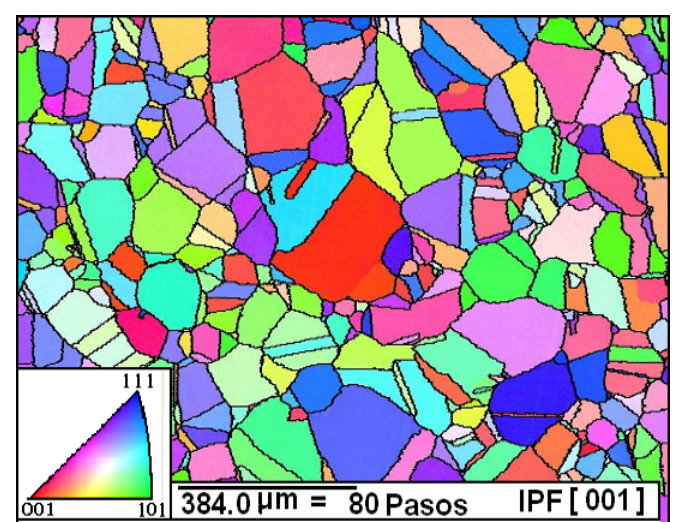

(a)

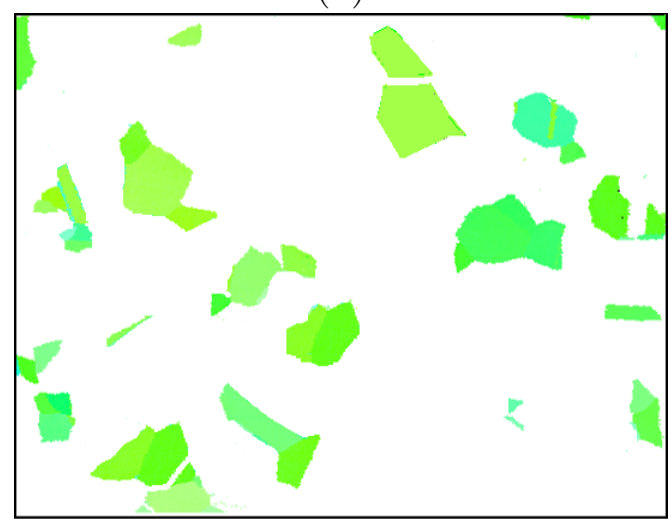

(c)

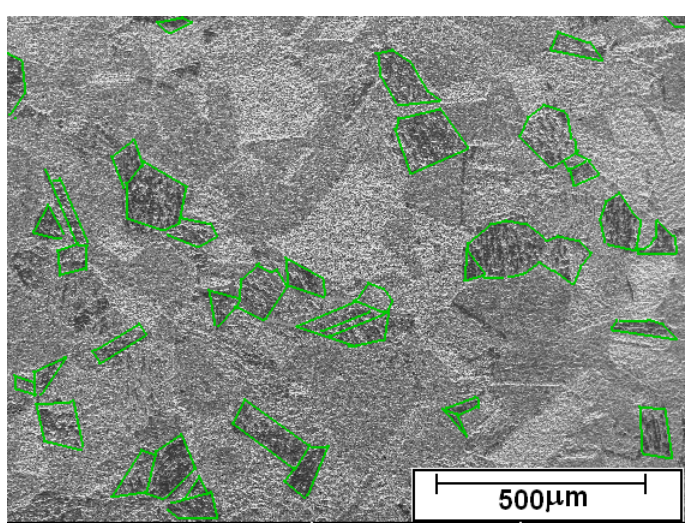

(b)

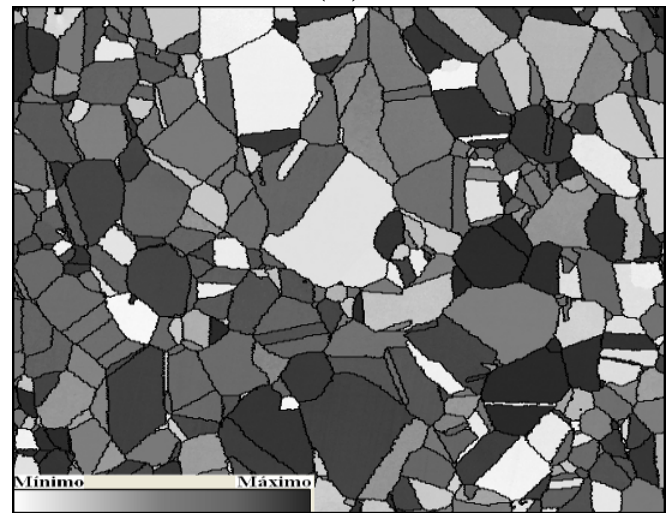

(d)

Figura 5.44: Para o aço 318HTGN+Lam+Sol após 64 horas de ensaio de desgaste EC: (a) mapa OIM, (b) micrografia MEV correspondente ao mapa em (a) com grãos 101 destacados, (c) Mapa OIM de contornos mais conservados correspondente com a figura (b), (d) mapa do FT (b) e (c).

Nas figuras 5.45 (a) a (d) se apresentam, para tempos intermediários de ensaio de desgaste EC de 9 e 25 horas, mapas e micrografias usadas para classificar visualmente o desgaste no interior dos grãos. Esta classificação tem como objetivo avaliar o efeito da orientação cristalográfica dos grãos do material na medida em que o dano vai-se acentuando. Este estudo foi realizado com ajuda do mapa de distribuição de orientações cristalográficas OIM mostrado na figura 5.45 (a), contendo aproximadamente 100 grãos com as mais diversas orientações cristalográficas, como se verifica na IPF mostrada na figura 5.45 (b), auxiliado por micrografias MEV da área sobre a superfície desgastada que tem correspondência com o mapa OIM, mostrando o estado da superfície desgastada por EC para os dois tempos analisados, figuras 5.45 (c) e (d).

Nas figuras 5.46 (a) a (j) são apresentados mapas OIM dos grãos com suas respectivas IPFs, colocadas ao lado direito do mapa com o qual se corresponde, que para os tempos de ensaio analisados (9 e 25 horas), apresentam valores 


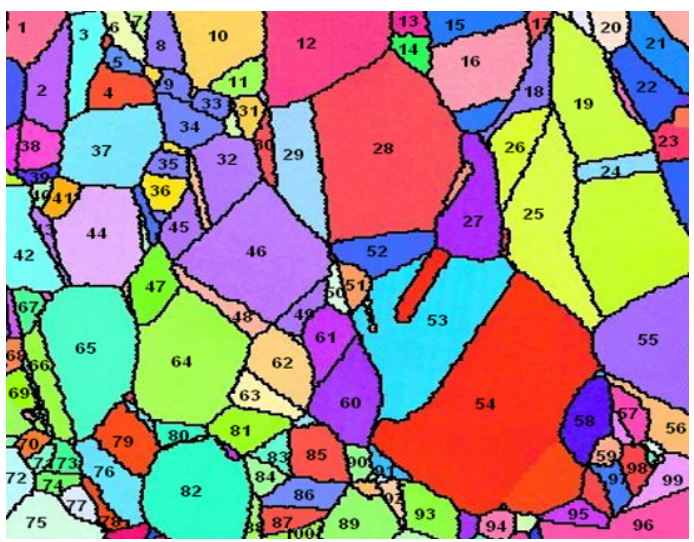

(a)

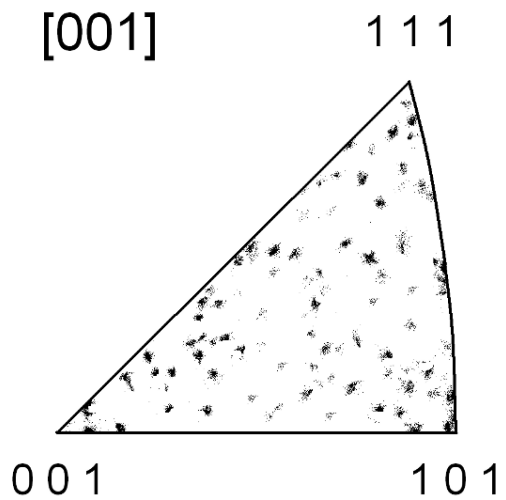

(c)

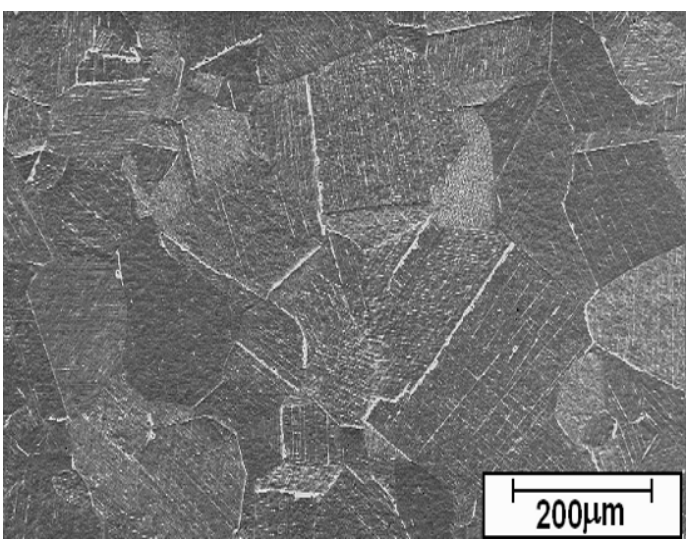

(b)

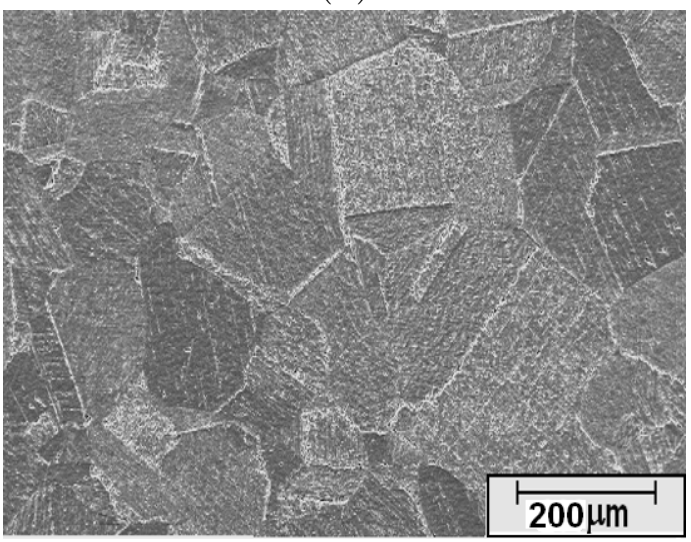

(d)

Figura 5.45: (a) Mapa OIM do aço 318HTGN+Lam+Sol de textura aleatória, contendo aproximadamente 100 grãos, usado para classificar o desgaste, (b) IPF correspondente com a figura (a), (c) e (d) são micrografias MEV onde se mostra a intensidade do desgaste para 9 e 25 horas de ensaio de desgaste EC, respectivamente.

particulares de resistência ao desgaste EC, segundo a classificação aqui adotada. Para classificar a quantidade de dano sofrido pelos grãos adotaram-se valores arbitrários na faixa de 1 a 5. Nessa classificação, o número 1 representa grãos com a melhor resistência, onde a superfície dos grãos se observa bastante conservada. Por outro lado, o número 5 representa grãos com a pior resistência, onde a aparência da superfície se observa em alto estado de deterioração. Para valores intermediários (2, 3 e 4), pode-se afirmar que o grau de deterioração dos grãos aumenta gradativamente. A classificação do desgaste em grãos foi realizada de forma arbitraria, usando critério visual.

Na figura 5.46 os mapas colocados nas colunas (a) a (e) e (f) a (j), em forma descendente, representam grãos com intensidade de desgaste de 1 a 5 respectivamente para os dois tempos de ensaio utilizados.

Dos mapas de distribuição de orientação cristalográfica (a) e (f) mostrados na figura 5.46 para 9 e 25 horas de ensaio respectivamente, pode-se notar que 


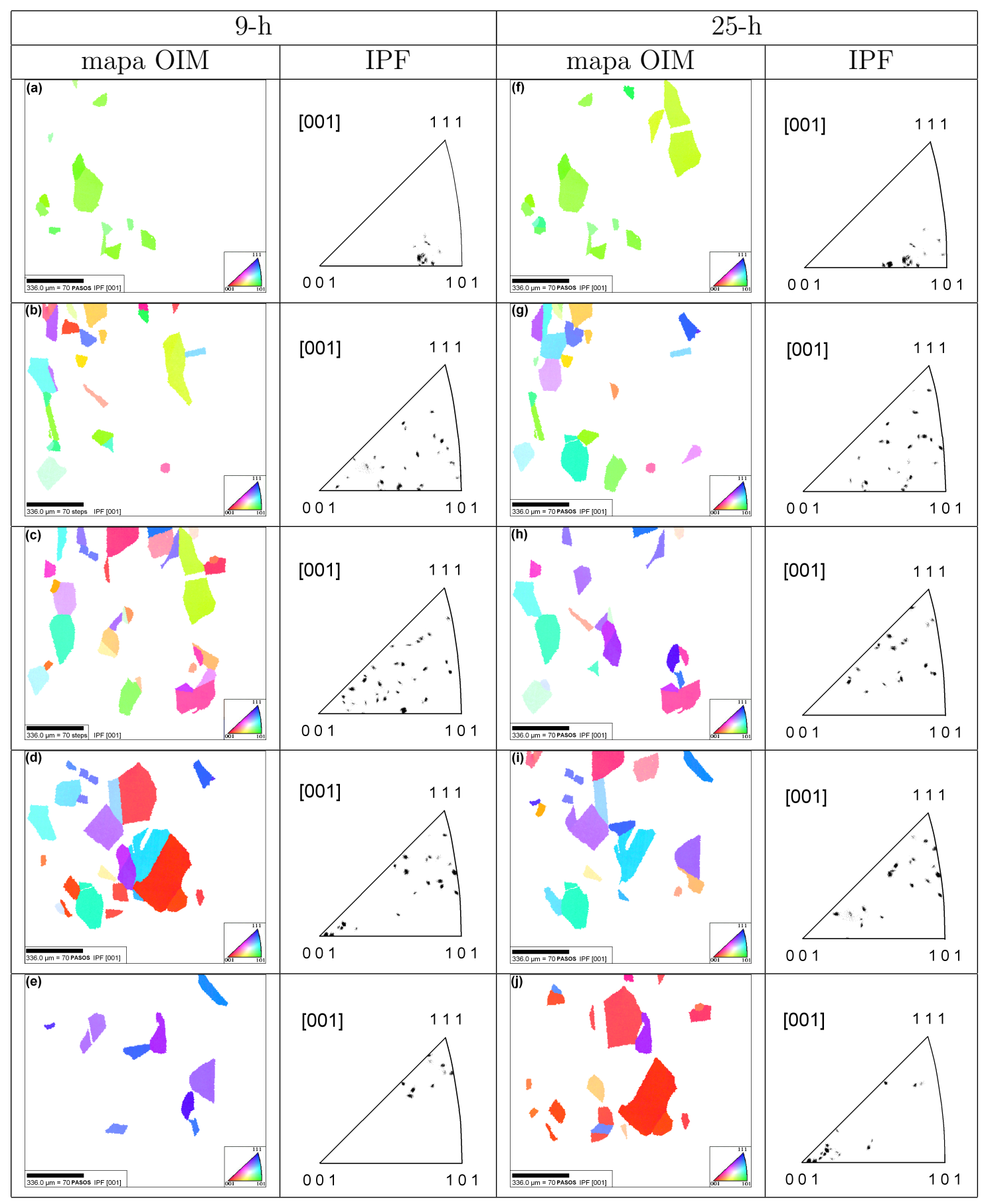

Figura 5.46: Mapas EBSD de grãos para o aço 318HTGN+Lam+Sol em destaque (colunas 1 e 3 ), com sua respectivas IPFs (colunas 2 e 4), correspondentes as micrografias mostradas nas figuras 5.45 (c) e (d) e usados para avaliar a resistência ao desgaste EC para 9 horas de ensaio (figuras (a) a

(e) e 25 horas de ensaio (figuras (f) a (j))

os grãos que apresentam uma maior resistência ao desgaste por EC, isto é, apresentam classificação 1, têm orientação cristalográfica próxima á família de planos 101 paralelo à superfície. Por outro lado, verifica-se também dos mapas das figuras 5.46 (d) e (e) para 9 horas de ensaio, e (e) e (j) para 25 horas de ensaio, que os grãos com o pior comportamento frente ao desgaste por EC têm orientações cristalinas próximas às da família de planos 111 e 001 paralelos à 
superfície. Já grãos com resistências ao desgaste por EC intermediárias, isto é 2, e 3, figura 5.46 (b) e (c) para 9 horas de ensaio e (g) a (h) para 25 horas de ensaio, apresentam orientações com os planos paralelos à superfície localizados entre as três orientações principais.

O comportamento diferenciado frente ao desgaste EC de grupos de grãos com diferente orientação cristalina explica muito bem a resistência ao desgaste encontrada para vários dos materiais ensaiados. Assim grãos com orientação 101 paralela à superfície apresentam a melhor resistência à EC, pois os sistemas de escorregamento $111\langle 110\rangle$ não estão numa orientação aproximadamente paralela aos planos de máxima tensão de cisalhamento situados em um cone a $45^{\circ}$ do eixo de aplicação de tensões. Nesses grãos a tensão crítica projetada para cisalhamento é maior e a deformação plástica (mecanismo por onde se inicia o dano por cavitação) só ocorre para níveis de tensão maiores ou para tempos de ensaio maiores. Tempos de ensaios maiores permitem acúmulo de dano por fadiga, devido à ocorrência de micro-deformação plástica, mesmo sob tensões abaixo da tensão crítica projetada.

\subsubsection{Relação entre desgaste erosivo por cavitação e tipos de contornos de grão}

O estudo do desenvolvimento do dano, nos contornos de grão, foi realizado no aço inoxidável 318HTGN+Lam+Sol de forma visual. Neste estudo pretende-se mostrar de forma gráfica, a variação da porcentagem de cada tipo de contornos de grão danificados, na medida em que avança o tempo de ensaio. Para isto foram utilizados mapas de tipos de contorno de grão obtidos através do software TSL/OIM, além de micrografias MEV, para os diferentes tempos de ensaio analisados (entre 4 e 25 horas).

Nas figura 5.47 (a) a (c) são apresentados os mapas dos tipos de contornos de grão existentes em uma região na superfície da amostra submetida a desgaste EC. O mapa tem aproximadamente 80 contornos CSL $\sum-3,35$ contornos do tipo outros CSL (CSL entre 5 e 27) e 105 contornos do tipo Não CSL, para um total de 220 segmentos de contornos. Os mapas das figuras 5.47 (b) e (c) apresentam em destaque os contornos do tipo CSL $\sum-3$ e outros CSL respectivamente.

Na figura 5.48 (a) a (d) são apresentadas micrografias MEV, da mesma região mapeada na figura 5.47 (a), para tempos de ensaio de 4, 9, 16 e 25 horas, que ajudaram a identificação e classificação dos contornos de grão entre danificados ou conservados. 


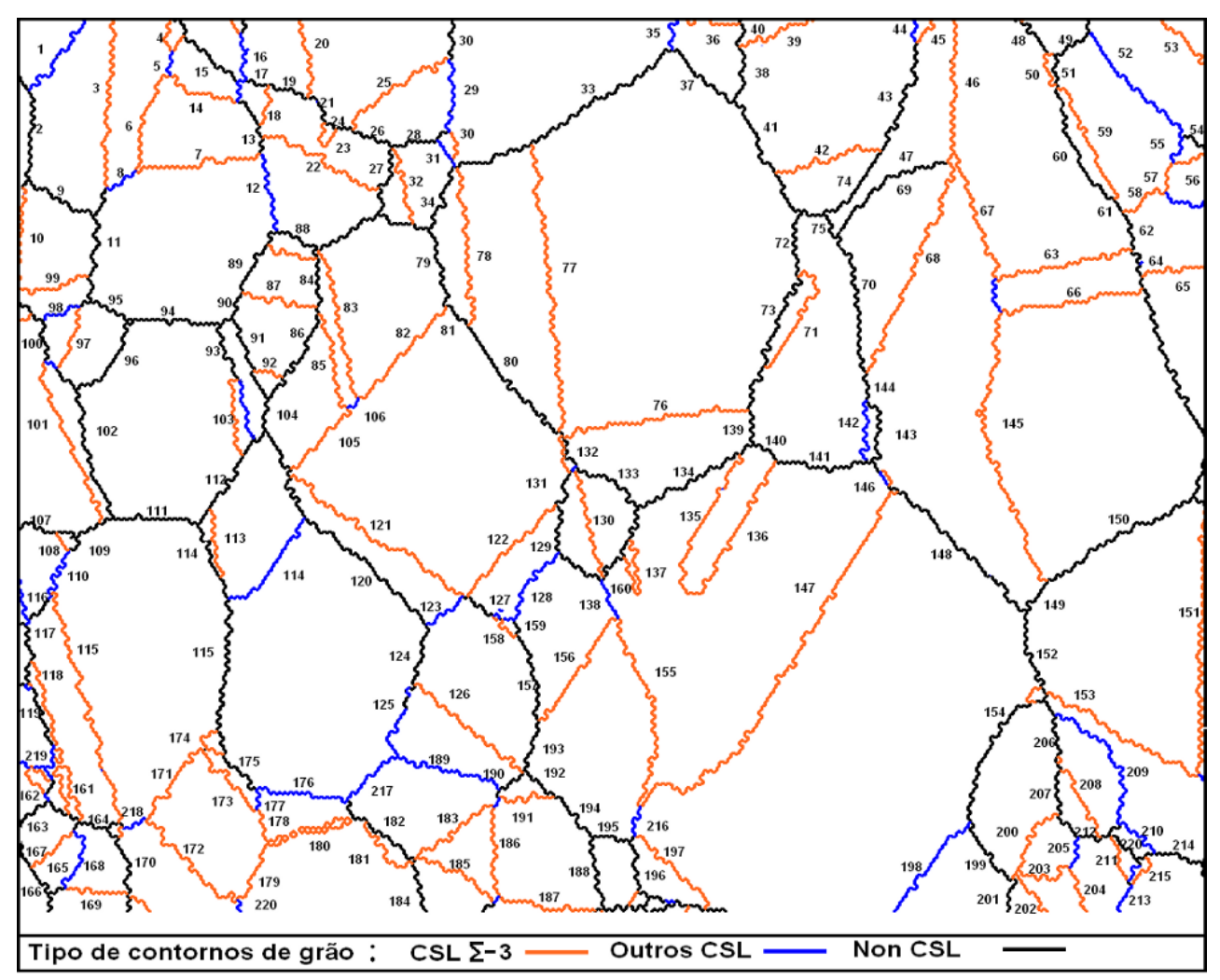

(a)

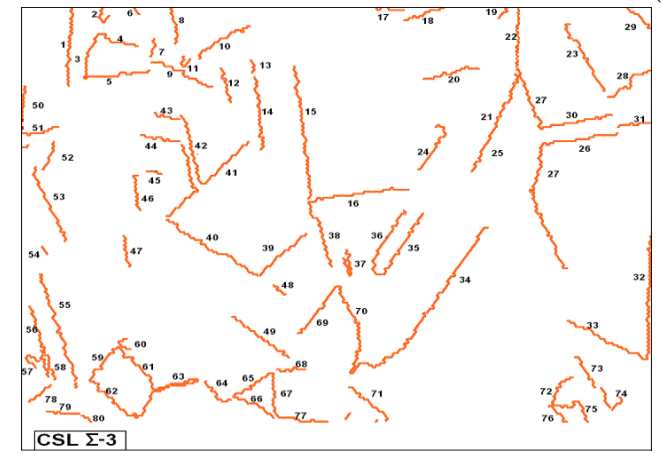

(b)

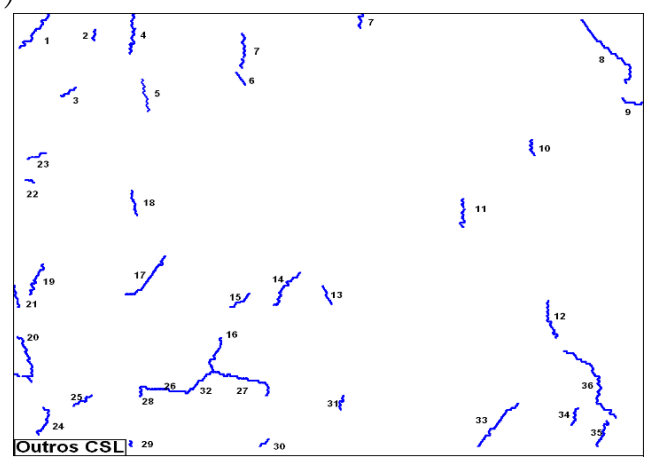

(c)

Figura 5.47: Para o aço 318HTGN+Lam+Sol apresenta-se mapas de tipos de contornos de grão assim: (a) CSL e Não CSL, (b) contornos CSL $\sum-3$ (maclas),

(c) outros CSL utilizados para analisar o desgaste em contornos de grão

No gráfico da figura 5.49 se apresenta o resultado da variação porcentual de contornos de grão, deteriorados para diferentes tempos de ensaio EC. A variação foi calculada individualmente levando em conta somente a quantidade de contornos de cada tipo.

No gráfico apresentado na figura 5.49 observa-se que os contornos de macla, do tipo $\sum-3$, são os mais propensos a serem danificados. O oposto ocorre com os contornos especiais diferentes do tipo $\sum-3$, os quais apresentaram maior resistência ao desgaste EC.

Observa-se, também, que para o maior tempo de ensaio utilizado (25 horas), 


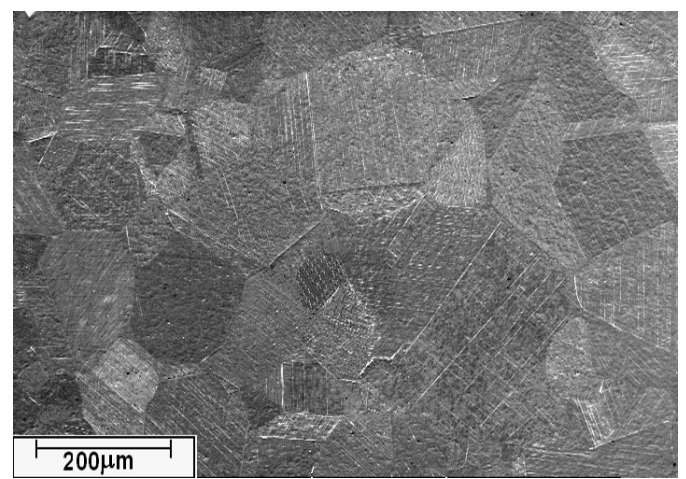

(a)

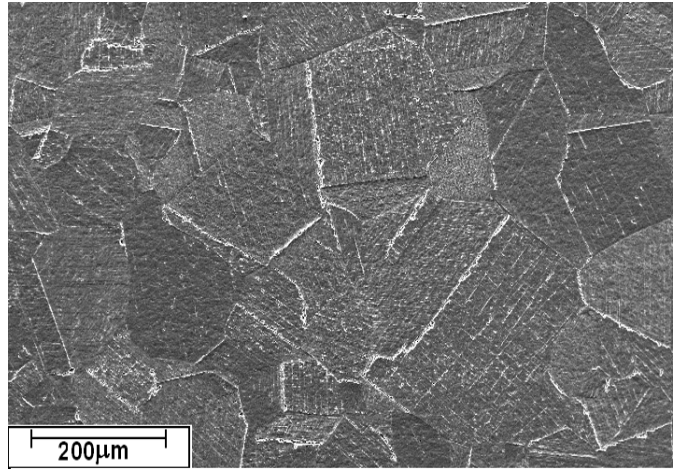

(c)

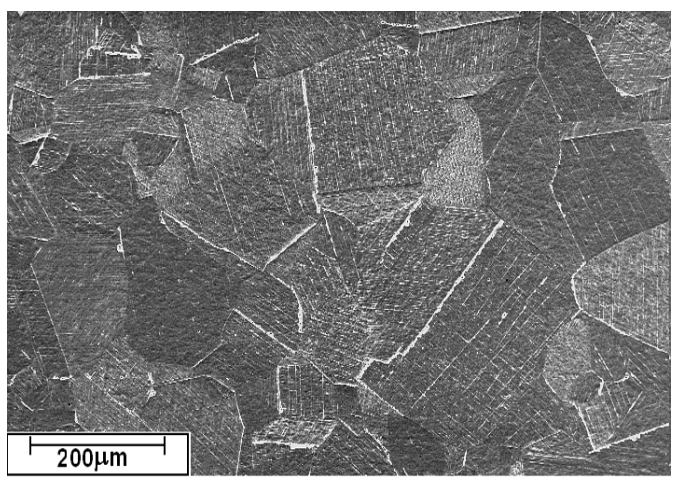

(b)

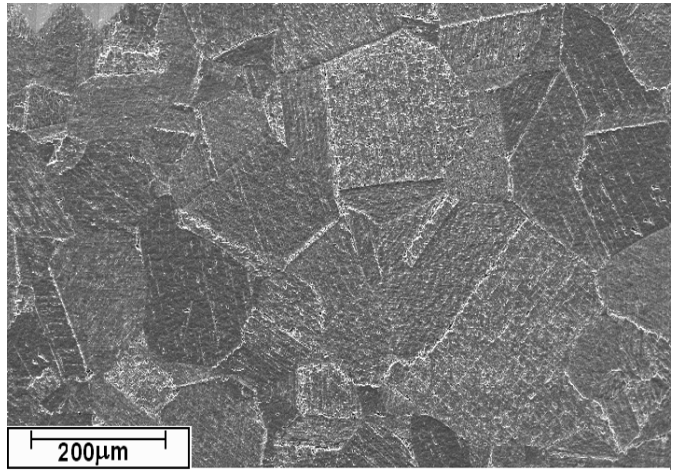

(d)

Figura 5.48: Para para o aço 318HTGN+Lam+Sol apresenta-se a superfície da amostra danificada durante o ensaio de desgaste EC. A região analisada é a mesma mapeada na figura 5.50 (a). Identificação e classificação do estado de diferentes tipos de contornos em função do tempo de ensaio EC: (a) 4h de EC:

(b) $9 \mathrm{~h}$ de EC, (c) $16 \mathrm{~h}$ de EC e (d) $25 \mathrm{~h}$ de EC.

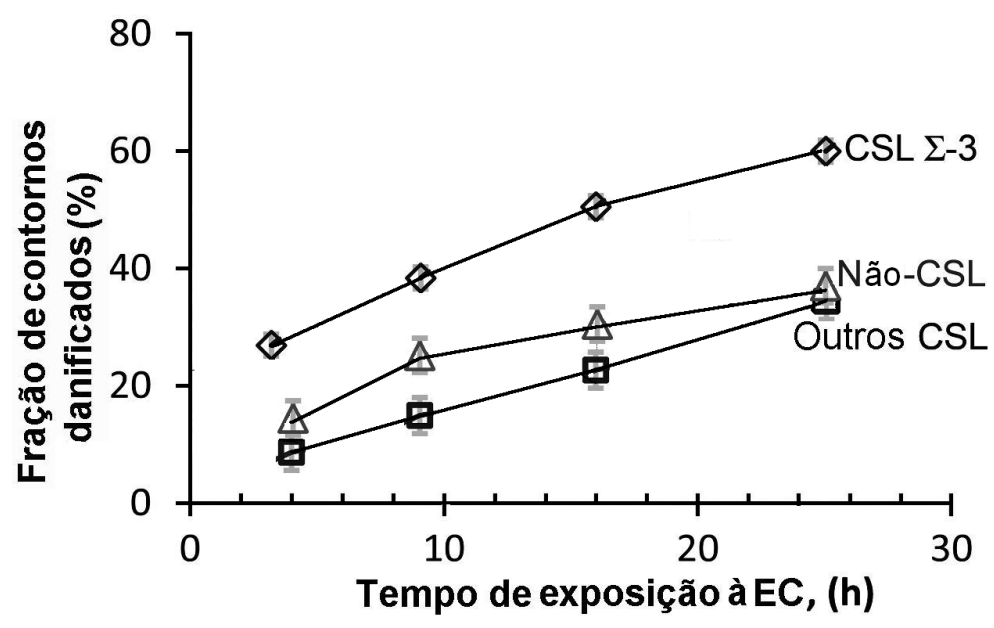

Figura 5.49: Para o aço $318 H T G N+L a m+S o l$, varição da porcentagem de tipos de contornos de grão danificados em função do tempo de exposição à EC, para contornos de grão especiais e não especiais.

aproximadamente $60 \%$ dos contornos do tipo CSL $\sum-3$ apresentam evidências de dano, porém aproximadamente 10 a $20 \%$ desses contornos se mantêm visivelmente conservados. Isto mostra que há uma fração deste tipo de contornos que apresenta uma melhor resistência ao desgaste EC. Para 25 horas de ensaio, 
a porcentagem de contornos danificados do tipo outros CSL e Nao CSL foi de $34,3 \%$ e $37,1 \%$ respectivamente.

Uma hipótese que pode explicar o comportamento dual dos contornos $C S L \sum-3$ refere-se à forma e à coerência dos contornos de macla, onde contornos de macla retos e coerentes são particularmente mais susceptíveis ao dano por EC do que contornos de macla com presença de segmentos incoerentes. Os contornos de macla incoerentes, por possuírem uma energia por unidade de área comparável à energia dos contornos de grão Não CSL (PADILHA, 2000), são mais difíceis de deformar plasticamente, como mostrado para os contornos do tipo Não CSL na figura 5.49 .

Paradoxalmente, uma pequena fração de contornos $C S L \sum-3$, exibiu uma elevada resistência ao desgaste EC. Esta observação confirma a dualidade do comportamento dos contornos $C S L \sum-3$ frente ao desgaste EC. As possíveis causas desta dualidade serão analisadas ao final da próxima seção.

\subsubsection{Relação entre orientação cristalográfica, desgaste EC em contornos de grão e FT}

As figuras 5.50 (a) a (c), para o aço 318HTGN+Lam+Sol, apresentam uma micrografia MEV e mapas EBSD de orientação cristalográfica e de fator de Taylor respectivamente. A micrografia da figura 5.50 (a) mostra uma região da área cavitada por 16 horas, onde se observa o estado de conservação ou dano da maioria de contornos de grão. O mapa de distribuição de orientações cristalográficas mostrado na figura 5.50 (b), correspondente à micrografia da figura 5.50 (a) foi utilizado para calcular FT, supondo compressão uniaxial normal à superfície, usando o software da TSL-OIM figura 5.50 (c).

Como discutido na seção 5.3.1, uma aproximação para o comportamento das tensões decorrentes da implosão de bolhas de cavitação, ao atingir uma superfície sólida, pode ser realizada tomando como modelo o modo de deformação por compressão uniaxial normal à superfície da amostra.

Conhecidos os valores do FT em cada um dos grãos, foi realizado o cálculo da variação do FT entre grãos separados por contornos que visualmente se observam conservados, para 16 horas de ensaio de desgaste por EC.

Na micrografia mostrada na figura 5.53 (a) percebe-se que para 16 horas de ensaio de desgaste EC, ainda existe uma grande quantidade de contornos de grão que permanecem conservados. 


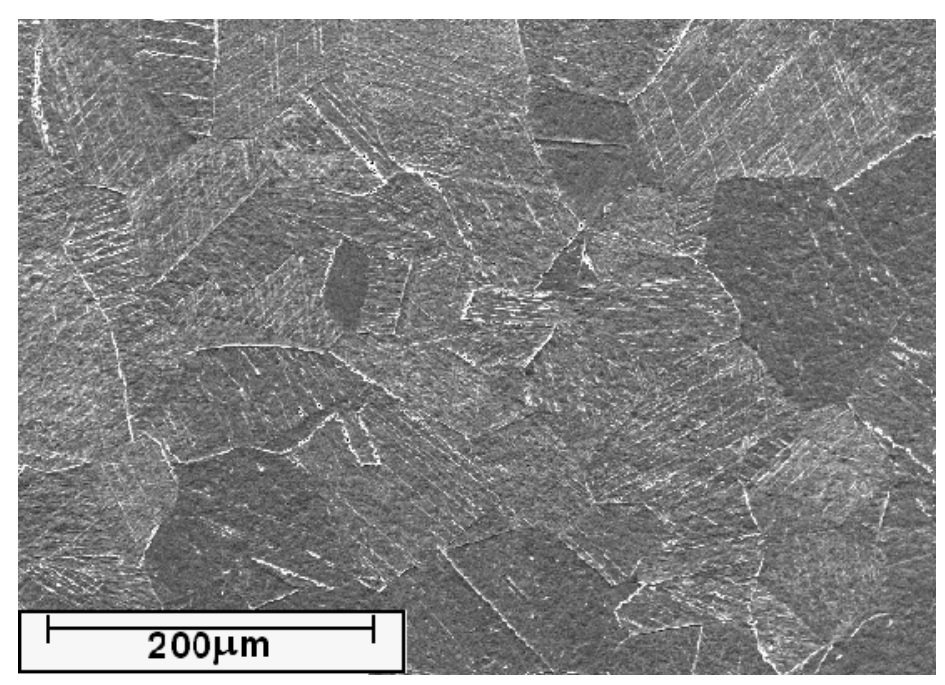

(a)

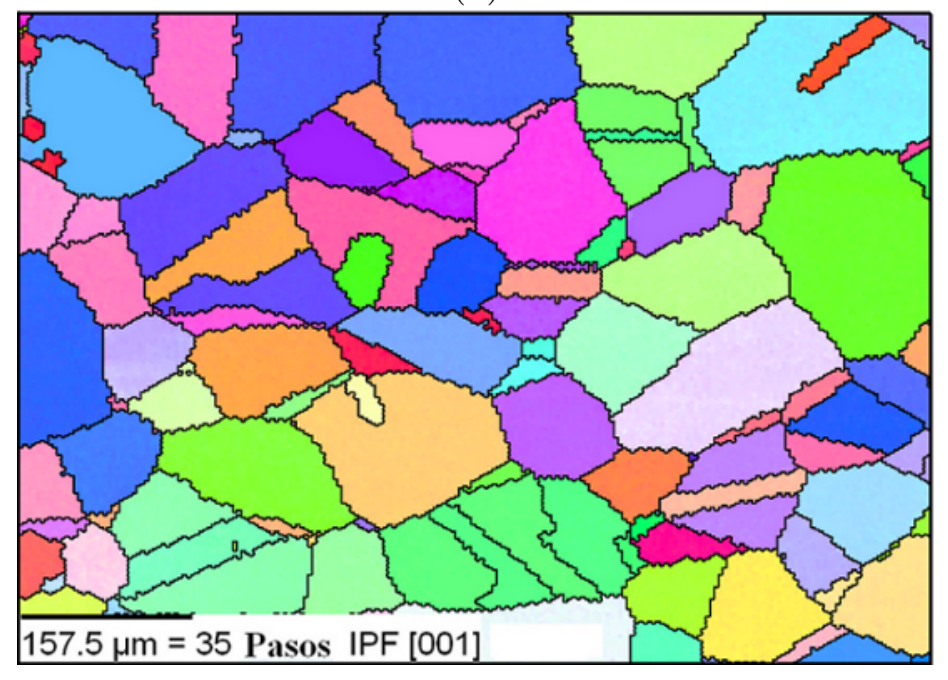

(b)

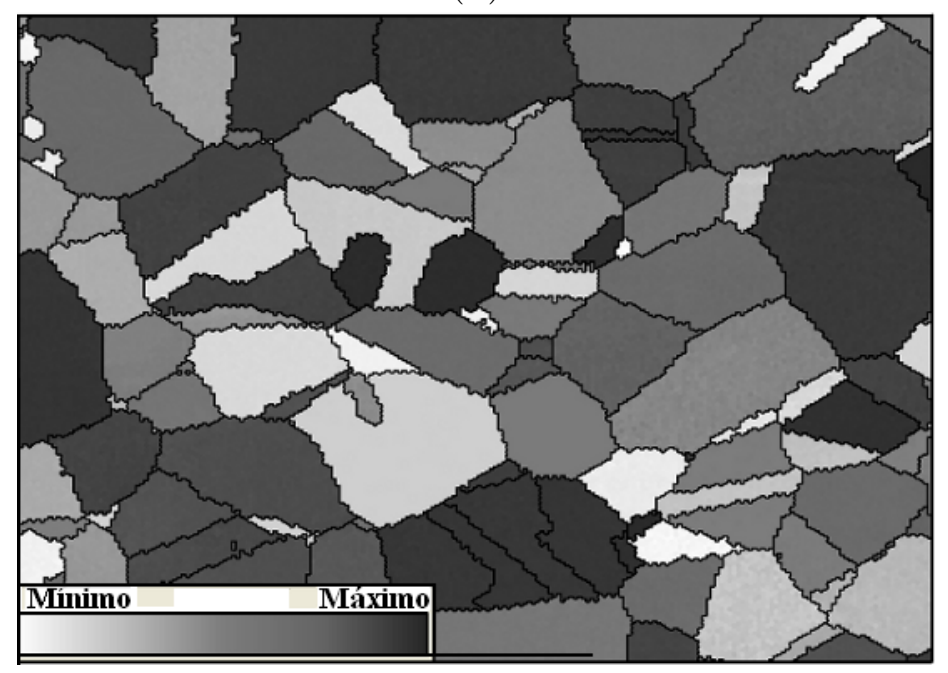

(c)

Figura 5.50: Para o aço 318HTGN+Lam+Sol: (a) micrografia MEV da superfície de uma amostra cavitada 16 h, (b) mapa OIM de orientação cristalográfica, (c) mapa de Taylor para tensão de compressão normal a superfície cavitada. 
Na figura 5.51 é apresentada a variação do FT dos grãos, em função da fração de contornos que visualmente se observam conservados, para 16 horas de ensaio de desgaste EC e calculada com ajuda das figuras 5.50 (a) a (c).

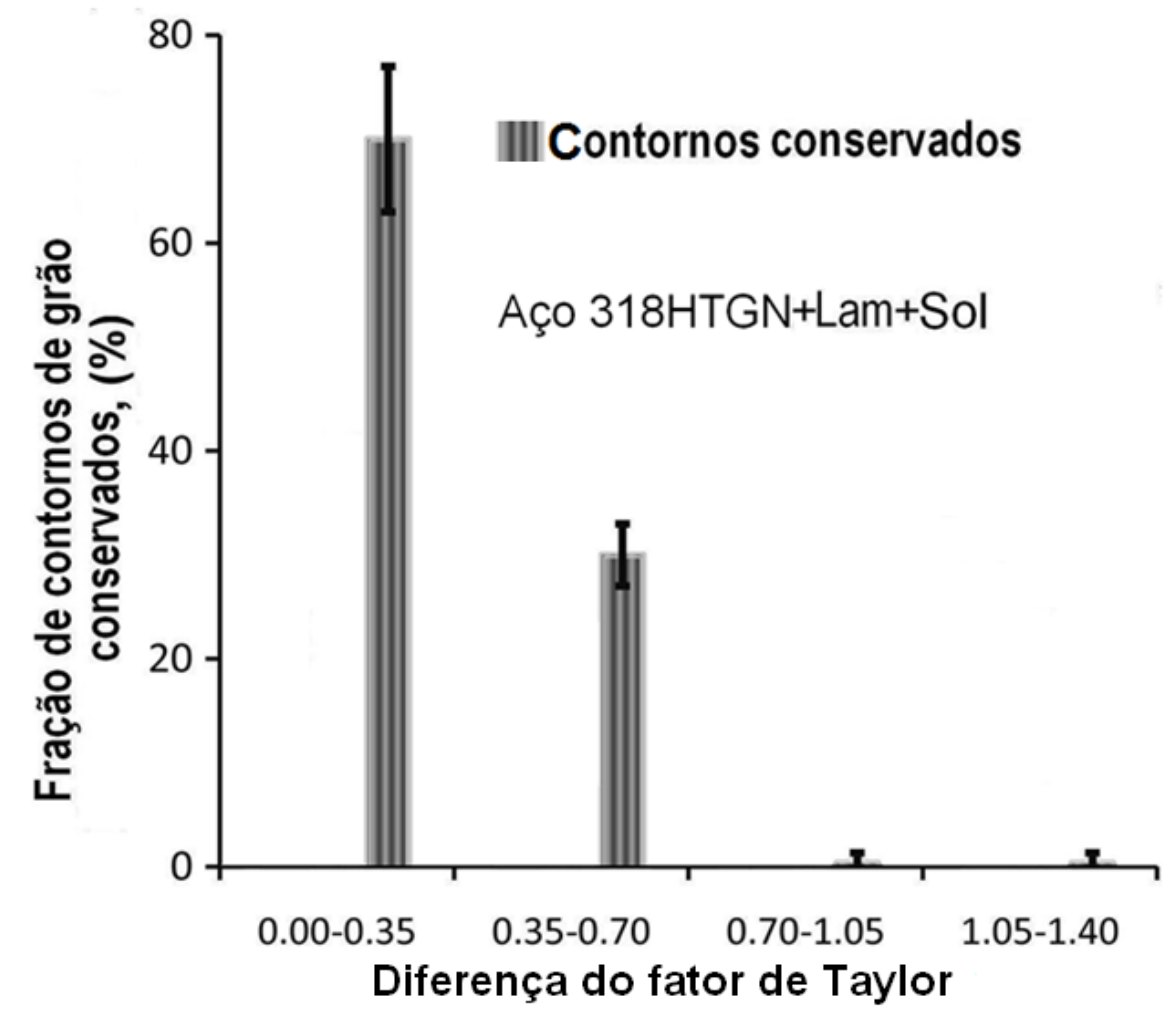

Figura 5.51: Diferença do fator de Taylor de grãos separados por contornos conservados para 16 horas de ensaio em experimentos de desgaste EC.

Sabendo que cada orientação cristalográfica leva a diferentes valores de tensão projetada crítica para deformação plástica "yield stress", observando o comportamento dos contornos nos gráficos da figura 5.51, pode-se validar a hipótese que "o dano em contornos de grão começa preferencialmente em contornos localizados entre grãos que têm maior diferença dos seus limites de escoamento, isto é, apresentam maior variação do fator de Taylor".

A maior diferença do FT entre grãos adjacentes leva a incompatibilidade de deformação plástica, induzindo concentração de tensões no contorno de grão, fazendo com que esses contornos sejam mais susceptíveis tanto a nucleação quanto ao avanço do dano.

Os resultados mostraram que a grande maioria de contornos $C S L \sum-3$ apresentou baixa resistência à deterioração frente ao desgaste EC, porém, como dito na seção 5.3.2, paradoxalmente, uma pequena fração deste tipo de contornos (entre 10 e $20 \%$ ) exibiram uma elevada resistência ao desgaste EC. Este aparente comportamento ambivalente deste tipo de contornos, pode ser atribuído a que em sua maioria, as relações de orientação entre cristais maclados levam a bruscas 
variações do FT entre os grãos, havendo, no entanto, uma pequena fração destas relações de orientação que também leva a insignificantes variações do FT entre os cristais maclados. Este último comportamento dual dos contornos do tipo $C S L \sum-3$ deve-se provavelmente, ao fato de que grãos maclados podem ter diferenças grandes ou pequenas do fator de Taylor, em função do valor do desvio do eixo de rotação para maclação com relação ao eixo normal à superfície da amostra, onde uma diferença pequena do fator de Taylor se apresenta quando a diferença entre o eixo para maclação e o eixo normal à superfície da amostra é também pequena, dando lugar a contornos altamente resistentes à EC e viceversa. 


\section{Conclusões}

\subsection{Condicionamento da superfície do aço UNS S31803}

- Como consequência da nitretação a gás em alta temperatura do aço inoxidável duplex UNS S31803, teve-se a formação de uma estrutura $100 \%$ austenítica com forte orientação cristalográfica preferencial dos grãos com planos $\{101\}$ paralelos à superfície da amostra, contendo aproximadamente $0,9 \% \mathrm{~N}$, tamanho de grão de $150 \mu m$ e dureza de $330 \mathrm{HV} 0,1$.

- A laminação a frio das amostras nitretadas a gás em alta temperatura com estrutura $100 \%$ austenítica, (30\% de grau de redução da seção transversal) causou encruamento da estrutura austenítica com heterogeneidade de deformação, encontrando-se alguns grãos mais deformados do que outros. A dureza aumentou para $470 \mathrm{HV} 0,1$.

- A laminação a frio das amostras nitretadas a gás em alta temperatura, com estrutura 100 \% austenítica, (30 \% de grau de redução da seção transversal), seguida de recristalização a $1200{ }^{\circ} \mathrm{C}$ por 1 hora, promoveram redução do tamanho de grão para $120 \mu m$ e distribuição aleatória de orientações cristalinas. A dureza foi mantida em 330 HV 0,1.

- A nitretação a gás em alta temperatura do aço UNS S31803, em condições que propiciaram a formação de nitretos dispersos em uma matriz austenítica, com tamanho de grão de $85 \mu \mathrm{m}$ e dureza de $330 \mathrm{HV}$ 0,1. A textura apresentada é semelhante à apresentada pelo aço com estrutura $100 \%$ austenítica, com predominância de grãos com planos $\{101\}$ paralelos à superfície da amostra.

- O tratamento duplex realizado no aço UNS S31803, consistindo em nitretação a gás em alta temperatura seguida de nitretação a plasma em baixa temperatura, resultou numa estrutura multicamadas constituída por uma camada austenítica de $100 \mu m$ de espessura e dureza de 330 HV 0,1, 
seguida de uma última camada de austenita expandida rica em nitrogênio com 2, $4 \mu \mathrm{m}$ de espessura e dureza de $1700 \mathrm{HV}$ 0,1. A textura da camada de austenita expandida é a mesma da austenita enriquecida em nitrogênio com predominância de grãos com planos 101 paralelos à superfície da amostra.

- A nitretação a plasma em baixa temperatura realizada no aço UNS S30403, em estado solubilizado, resultou numa estrutura multicamadas constituída

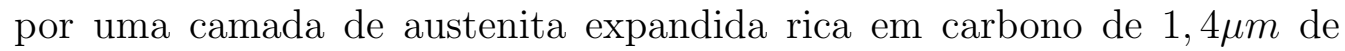
espessura e dureza de 1000 HV 0,1, seguida de uma última camada de austenita expandida rica em nitrogênio com 2,6 $\mu m$ de espessura e dureza de $1500 \mathrm{HV} 0,1$.

\subsection{Desempenho do aço UNS S31803 tratado superficialmente em ensaios de Erosão Cavitação}

- Quando comparados com a superliga de cobalto Stellite-6, os aços inoxidáveis nitretados em alta temperatura, com nitrogênio em solução sólida, 318HTGN+Lam+Sol, 318HTGN+Sol e 318HTGN+Enc apresentaram uma melhora na taxa de desgaste EC de 1,82; 1,96 e 10,6 vezes respectivamente. Já para o aço inoxidável 318HTGN+Plas a melhora foi de 21,2 vezes.

- Com relação aos materiais sem nitrogênio 318CR e 304LSol, os aços nitretados em alta temperatura tiveram uma melhorara significativa da taxa de desgaste EC, onde o aço 318HTGN+Sol superou em 61,1 e 26,8 vezes respectivamente a taxa de desgaste daqueles materiais.

- Os aços 318HGTN+plas submetido a tratamento duplex e 318HGTN+Enc tiveram o melhor comportamento frente ao desgaste EC, representado pela diminuição da taxa de desgaste exibida com relação aos materiais de comparação e aos próprios aços nitretados a gás. Estes dois materiais superaram em 10,8 e 5,4 vezes respectivamente a taxa de desgaste apresentada pelo aço $318 \mathrm{HGTN}+$ Sol, que foi o material melhor comportado do tipo de aços nitretados a gás com nitrogênio em solução sólida, e em 660 e 330 vezes respectivamente a taxa de desgaste do aço 318CR. 


\subsection{Das relações entre desgaste por cavitação e características cristalográficas}

- Verificou-se para os diferentes tipos de aços utilizadas, que a deterioração da superfície durante os ensaios se apresentou de forma heterogênea e que grãos com planos da família 101 orientados paralelamente à superfície das amostras, foram os que apresentaram o melhor desempenho frente a este tipo de desgaste.

- Contornos de macla CSL $\Sigma-3$ são os contornos de grãos mais suscetíveis ao dano por EC, quando separados por regiões com alta anisotropia plástica. Já contornos CSL diferentes de $\Sigma-3$ apresentaram o melhor desempenho em relação aos CSL $\Sigma-3$ e aos não CSL.

- Foi possível fazer a correlação entre textura, resistência ao desgaste EC e fator de Taylor ao se verificar que grãos com orientação cristalina 101 paralela à superfície se comportaram como os mais preservados durante os ensaios de desgaste EC.

- Observou-se correlação entre os valores do fator de Taylor de cada grão e a probabilidade de os grãos sofrerem dano por EC.

- Observou-se correlação entre dano por cavitação iniciado em contornos de grão e a diferença entre os fatores de Taylor de grãos vizinhos. O dano em contornos de grão se apresenta preferencialmente em contornos localizados entre grãos que têm maior diferença de limites de escoamento, isto é, apresentam maior variação do FT.

- Para maiores tempos de ensaio entre $70 \%$ e $80 \%$ dos contornos CSL $\Sigma-3$ apresentaram evidências de dano, porém entre 10 a $20 \%$ desses contornos se mantiveram conservados, indicando elevada resistência ao desgaste EC. Essas diferenças podem ser atribuídas a diferenças de fator de Taylor entre grãos vizinhos e entre regiões macladas no interior de um mesmo grão. 


\section{Sugestões para trabalhos futuros}

- Estudar os mecanismos de transformação da estrutura duplex $(\gamma+\alpha)$ do aço UNS 31803 em austenita e em seguida em austenita expandida e correlacionar com a textura e a resistência à cavitação.

- Quantificar os efeitos de tamanho de grão, tipo de contorno, textura e fator de Taylor na resistência à cavitação de aços austeníticos convencionais e de alto teor de nitrogênio.

- Estudar a possibilidade de realizar tratamentos duplex em um único ciclo de nitretação a plasma para enriquecimento da superfície em nitrogênio, seguido de tratamento de difusão para formação de camada austenítica espessa, contendo elevado teor de nitrogênio em solução sólida, com função de reforço mecânico.

- Estudar o efeito de tratamentos de shot-peening na resistência à cavitação de aços austeníticos convencionais e de aços de alto nitrogênio

- Avaliar outros tipos de desgaste em aços inoxidáveis austeníticos nitretados em alta temperatura e nitretados a plasma. 


\section{Referências}

AHMED, S.; HOKKIRIGAWA, K.; OBA, R. Fatigue failure of sus 304 caused by vibratory cavitation erosion. Wear, v. 177, n. 2, p. 129 - 137, 1994.

ARCHARD, J. Contact and rubbing of flat surfaces. Journal of Applied Physics, v. 24, n. 8, p. 981-988, 1953.

ARRIS, S.; ALEXANDER, A. The joukowsky equation for fluids and solids. In: The joukowsky equation for fluids and solids. November 2009. http://alexandria.tue.nl/repository/books/609455.pdf.

ASM-HANDBOOK-VOL-18. Friction, Lubrication, and Wear Technology. 18. ed. Ohio: American Society for Metals, 1992.

ASM-HANDBOOK-VOL:2. ASM Heat treating. 9th. ed. [S.l.]: American Society for Metals, 1991.

ASTM-E112. ASTM-E112 Standard test methods for determining average grain size. In: Standard test methods for determining average grain size. United States, 2004.

ASTM-E407. Standard practice for microetching metals and alloys. USA, 2007.

ASTM-G32. Standard test method for cavitation erosion using vibratory apparatus. 2009. ASTM-G32/2009.

ASTM-G40. Standard terminology relating to wear and erosion. USA, 2010.

BEDKOWSKI, W.; GASIAK, G.; LACHOWICZ, C.; LICHTAROWICZ, A.; LAGODA, T.; MACHA, E. Relations between cavitation erosion resistance of materials and their fatigue strength under random loading. Wear, v. 230, n. 2, p. $201-209,1999$.

BERNS, H.; SIEBERT, S. High nitrogen austenitic cases in stainless steels. ISIJ, v. 36, n. 7, p. 927-931, 1996.

BHADESHIA, H.; HONEYCOMBE, R. Steels : Microstructure and properties. London, edition = 3ra,: E. Arnold, 2006.

BHUSHAN, B. Principles and applications of tribology. First. New York: Wiley, 1999.

BISHOP, J.; HILL, R. A theoretical derivation of the plastic properties of a polycrystalline face-centred metal. Philosophical Magazine, v. 42, n. 334, p. 1298-1307, 1951.

BREGLIOZZI, G.; SCHINO, A. D.; AHMED, S.-U.; KENNY, J.; HAEFKE, H. Cavitation wear behaviour of austenitic stainless steels with different grain sizes. Wear, v. 258, n. 1-4, p. $503-510,2005$. 
BUNGE., H. J. Texture analysis in materials science mathematical methods. Second. USA: CUVILLIER VERLAG, 1993.

CAlAINHO, L.; HORTA, A.; GONÇALVES, C.; LOMÔNACO, G. Cavitação em turbinas hidráulicas do tipo francis e kaplan no brasil -proceedings xv seminário nacional de produção e transmissão de energia elétrica snptee. Foz de Iguaçu - Paraná - Brasil, Junho 1999.

CALLISTER, W. Fundamentals of materials science and engineering. 7th. ed. New York,: Wiley, 2006.

CHEN, H.; LIU, J.; CHEN, D.; JIADAO, W. Damages on steel surface at the incubation stage of the vibration. Wear, v. 265, p. 692-698, 2008.

CHEN, H.; LIU, S. Inelastic damages by stress wave on steel surface at the incubation stage of vibration cavitation erosion. wear, v. 266, n. 1-2, p. 69-75, 2009 .

CHIN, G. Metallography and microstructures. first. Ohio: ASM International, 1985.

COURTAS, S.; GRéGOIRE, M.; FEDERSPIEL, X.; BICAïS-LEPINAY, N.; WYON, C. Electron backscattered diffraction (ebsd) use and applications in newest technologies development. Microelectronics and Reliability, v. 46, n. 9-11, p. $1530-1535,2006$.

CUPPARI, M.; SOUZA, R.; SINATORA, A. Effect of hard second phase on cavitation erosion of fe-cr-ni-c alloys. Wear, v. 258, n. 1-4, p. $596-603,2005$.

DAVIS, J. Stainless steels. first. New York: ASM International, 1994.

DINGLEY, D.; RANDLE, V. Microtexture determination by electron back-scatter diffraction. Journal of Materials Science, v. 27, n. 17, p. 4545-4566, 1992.

EDWARDS, D.; JONES, I. An experimental study of forces generated by the collapse of transient cavities in water. Fluid Mech, v. 7, n. 4, p. 596-609, 1960.

FACTOR, M.; ROMAN, I. Microhardness as a simple means of estimating relative wear resistance of carbide thermal spray coatings: Part 1 characterization of cemented carbide coatings. Journal of Thermal Spray Technology, v. 11, n. 4, p. $468-481,2002$.

FACTOR, M.; ROMAN, I. Use of microhardness as a simple means of estimating relative wear resistance of carbide thermal spray coatings: Part 2. wear resistance of cemented carbide coatings. Journal of Thermal Spray Technology, v. 11, n. 4, p. 482-495, 2002.

FEICHTINGER, H.; ZHEN, X. Powder metallurgy of high nitrogen stainless steels. Powder Metallurgy International, v. 22, n. 2, p. 7-13, 1990.

GARVART, L.; MONTHEILLET, F. Dynamic recristallization and grain refinement in a high purity 3041 type austenitic stainless steel. Materiaux $\mathscr{E}$ techniques, n. 5-6, p. 65-68, 2000. 
GARZÓN, C. Transformações de fase e mudanças de textura cristalográfica durante a nitretação gasosa em alta temperatura de aços inoxidáveis. Tese (Doutorado) - Universidade de São Paulo, São Paulo, 2004.

GARZÓN, C.; TSCHIPTSCHIN, A. Textura e relações de orientação em camadas obtidas por nitretação superficial de aços inoxidáveis em alta temperatura. II workshop sobre textura e relações de orientação-Escola Politécnica da USP, São Paulo, p. 309-328, 2003.

GARZÓN, C.; TSCHIPTSCHIN, A. New high temperature gas nitriding cycle that enhances the wear resistance of duplex stainless steels. ournal of Materials Science, v. 39, n. 23, p. 7101-7105, 2004.

GARZÓN, C.; TSCHIPTSCHIN, A. P.; THOMAS, H.; SANTOS, F. Cavitation erosion resistance of a high temperature gas nitrided duplex stainless steel in substitute ocean water. Wear, v. 259, n. 1-6, p. 145 - 153, 2005.

GAVRILJUK, V.; BERNS, H. High nitrogen steels : Structure, properties, manufacture, applications. first. New York: Springer, 1999.

GAVRILJUK, V.; SHANINA, B.; BERNS, H. A physical concept for alloying steels with carbon + nitrogen. Materials Science and Engineering: A, v. 481-482, p. $707-712,2008$.

GAVRILJUK, V.; SHIVANYUK, V.; SHANINA, B. Change in the electron structure caused by $\mathrm{c}, \mathrm{n}$ and $\mathrm{h}$ atoms in iron and its effect on their interaction with dislocations. Acta Materialia, v. 53, n. 19, p. 5017-5024, 2005.

GLAVATSKAYA, N. I.; SOZINOV, A.; PETROV, Y. N. Grain boundary strengthening in austenitic nitrogen steels. Materials Science and Engineering a-Structural Materials Properties Microstructure and Processing, v. 271, n. 1-2, p. 14-21, 1999.

GODEC, M.; JENKO, M. Presentation methods of textures measurements. materials $\&$ tehnology, v. 34, n. 6, p. 359-364, 2000.

GONTIJO, L.; MACHADO, R.; MIOLA, E.; CASTELETTI, L.; NASCENTE, P. Estudo da estrutura da fase s no aço aisi 3161 por difração de raios x e espectroscopia mössbauer. Revista Brasileira de Aplicações de Vácuo, v. 24, n. 2, p. 81-86, 2005.

G.PALUMBO; AUST, K.; ERB, U.; P.LIN. On a more restrictive geometric criterion for special csl grain boundaries. Escripta materialia, v. 38, n. 11, p. 1685-1690, 1998.

GWIDON, W. Wear materials, mechanisms and practice. second. England: John Wiley \& Sons, 2006.

HAMMITT, F. G. Damage to solids caused by cavitation. Philosophical Transactions for the Royal Society of London. Series A, Mathematical and Physical Sciences, v. 260, p. 245-255, 1966.

HATTORI, S.; ISHIKURA, R. Revision of cavitation erosion database and analysis of stainless steel data. Wear, v. 268, n. 1-2, p. 109 - 116, 2010. 
HATTORI, S.; MIKAMI, N. Cavitation erosion resistance of stellite alloy weld overlays. Wear, v. 267, p. $154-160,2009$.

HEAT-TECH, L. Nitretação sob plasma pulsado. Março 2007. http:

//www.heattech.com.br/releases.html\#ArtigosTecnicos.

HEATHCOCK, C.; BALL, A.; PROTHEROE, B. Cavitation erosion of cobalt-based stellite $\AA$ alloys, cemented carbides and surface-treated low alloy steels. Wear, v. 74, n. 1, p. $11-26,1981$.

HEATHCOCK, C.; BALL, A.; PROTHEROE, B. Cavitation erosion of stainless steels. Wear, v. 81, n. 1, p. 311-327, 1982.

HOROVITZ, M.; NETO, F.; GARBOGINI, A.; TSCHIPTSCHIN, A. Nitrogen bearing martensitic stainless steels: Microstructure and properties. ISIJ

International, v. 36, n. 7, p. 840-845, 1996.

HULL, D.; BACON, D. Introduction to dislocations. 4th. ed. Boston: Butterworth-Heinemann, 2001.

HUMPRHEYS, F.; HATHERLY, M. Recrystallization and related anneling phenomena. first. UK: Pergamon Press, 1996.

HUTCHINGS, I. M. Tribology Friction and wear of engineering materials. First. England: Elsevier, 1992.

IWAI, Y.; OKADA, T.; TANAKA, S. A study of cavitation bubble collapse pressures and erosion part 2: Estimation of erosion from the distribution of bubble collapse pressures. Wear, v. 133, n. 2, p. 233 - 243, 1989.

JEAN, P.; JEAN, M. Fundamentals of cavitation. first. NEW YORK: KLUWER ACADEMIC PUBLISHERS, 2005.

KESTENBACH, H. Estudos de textura no microscópio eletrônico de transmissão. I workshop sobre textura e relações de orientação "deformação plástica, recristalização, crescimento de grão, São Paulo, p. 411-440, 2003.

KLAPKIV, M.; POVSTYANA, N.; NYKYFORCHYN, H. Production of conversion oxide-ceramic coatings on zirconium and titanium alloys. Materials Science, v. 42, n. 2, p. 277-286, 2006.

KRAUSS, G. Steels : Processing, structure, and performance. first. Ohio: Materials Park - ASM International, 2005.

KRELLA, A.; CZYZNIEWSKI, A. Cavitation erosion resistance of nanocrystalline tin coating deposited on stainless steel. Wear, v. 265, n. 7-8, p. $963-970,2008$.

KRELLA, A.; CZYZNIEWSKI, A. Investigation concerning the cavitation resistance of tin coatings deposited on austenitic stainless steel at various temperatures. Wear, v. 265, n. 1-2, p. $72-80,2008$.

LEIBNIZ-INSTITUTE. Electron back-scatter diffraction (EBSD). first. German: Institute for Complex Materials, 2007. 
LIMA, N. de; LIMA, L. de; PADILHA, A. Texturas de recristalização. II workshop sobre textura e relações de orientação-Escola Politécnica da USP, São Paulo, p. 107-128, 2003.

LIN, P.; PALUMBO, G.; ERB, U.; AUST, K. Influence of grain-boundarycharacter-distribution on sensitization and intergranular corrosion of alloy-600. Scripta Metallurgica Et Materialia, v. 33, n. 9, p. 1387-1392, 1995.

LIU, W.; ZHENG, Y.; LIU, C.; YAO, Z.; KE, W. Cavitation erosion behavior of crmnn stainless steels in comparison with 0cr13ni5mo stainless steel. Wear, v. 266, n. $1-2$, p. $69-75,2009$.

LO, K.; CHENG, F.; MAN, H. Laser transformation hardening of aisi 440c martensitic stainless steel for higher cavitation erosion resistance. Surface $\mathcal{E}$ Coatings Technology, v. 173, n. 1, p. 96-104, 2003.

MATHIAS, M.; POHL, M. The residual stress, texture and surface changes in steel induced by cavitation. Wear, v. 150, p. $11-20,1991$.

MENTHE, E.; BULAK, A.; OLFE, J.; ZIMMERMANN, A.; RIE, K. Improvement of the mechanical properties of austenitic stainless steel after plasma nitriding. Surface \& Coatings Technology, v. 133, p. 259-263, 2000.

MESA, D. H.; GARZÓN, C.; TSCHIPTSCHIN, A. Estudio del desgaste erosivo por cavitación a nivel del tipo de límites de grano y orientación cristalina de los granos en un acero inoxidable austenítico de alto nitrógeno. Scientia et Technica, v. 41, n. 1, p. 291-296, 2009a.

MESA, D. H.; GARZÓN, C.; TSCHIPTSCHIN, A. P. Meso-anisotropia da deformação plástica e do desgaste durante a erosão por cavitação de um aço austenítico com alto teor de nitrogênio. $63^{\circ}$ Congresso da ABM, Santos - São Paulo, p. 3704-3712, 2008.

MESA, D. H.; GARZÓN, C.; TSCHIPTSCHIN, A. P. Mesoscale plasticity anisotropy at the earliest stages of cavitation-erosion damage of a high nitrogen austenitic stainless steel. Wear, v. 267, n. 1-4, p. 99 - 103, 2009b.

MESA, D. H.; TORO, A.; SINATORA, A.; TSCHIPTSCHIN, A. P. The effect of testing temperature on corrosion-erosion resistance of martensitic stainless steels. Wear, v. 255, n. 1-6, p. 139 - 145, 2003.

MEYERS, M.; CHAWLA, K. Mechanical Behavior of Materials. second. USA: Cambridge University Press, 2008.

MILLER, G.; PURSEY, H. On the partition of energy between elastic waves in a semi-infinite solid. Proc. Royal Soc., London, v. 233, n. 55-59, p. 69-75, 1955.

MOMMA, T.; LICHTAROWICZ, A. A study of pressures and erosion produced by collapsing cavitation. Wear, v. 186-187, n. Part 2, p. 425 - 436, 1995.

OSSA, C.; TSCHIPTSCHIN, A.; ROGERO, S. Cytotoxicity study of plasmasprayed hydroxyapatite coating on high nitrogen austenitic stainless steels.

Journal of Materials Science: Materials in Medicine, v. 17, n. 3, p. 1095 -1100, 2006 . 
PADILHA, A. Materiais de engenharia microestrutura e propriedades. first. São Paulo: Hemus S.A, 2000.

PETERSON, M.; WINER, W. Wear control handbook. First. New York: American Society of Mechanical Engineers, ASME, 1980.

PLESSET, M.; CHAPMAN, R. Collapse of an initially spherical cavity in the neighbourhood of a solid boundary. Journal of Fluid Mechanics, v. 47, n. 2, p. 283-290, 1971.

PRESSER, R.; SILCOCK, J. Aging behavior of 18mn-18cr high nitrogen austenitic steel for end rings. Metal Science, v. 17, n. 5, p. 241-247, 1983.

PRZYBYLA, C.; ADAMS, B.; MILES, M. Methodology for determining the variance of the taylor factor: Application in fe-3 Journal of Engineering Materials and Technology-Transactions of the Asme, v. 129, n. 1, p. 82-93, 2007.

QIAO, Y.; ZHENG, Y.; WU, X.; KE, W.; YANG, K.; JIANG, Z. Cavitation erosion resistance of high nitrogen stainless steel in comparison with low $\mathrm{n}$ content cr-mn-n stainless steel. Tribology - Materials, Surfaces $\&$ Interfaces, v. 1, n. 3, p. 165-172, 2007.

RABINOWICZ. ear coeficients-metals, wear control handbook. second. New York: ASME, 1980.

RANDLE, V.; ENGLER, O. Introduction to texture analysis : Macrotexture, microtexture and orientation mapping. first. Amsterdam: Gordon \& Breach, 2000 .

RAWERS, J.; DUNNING, J.; ASAI, G.; REED, R. Characterization of stainless steels melted under high nitrogen pressure. Journal Metallurgical and Materials Transactions A, v. 23, n. 7, p. 2061-2068, 1992.

RAWERS, J.; MAURICE, D. Understanding mechanical infusion of nitrogen into iron powders. Acta Metallurgica Et Materialia, v. 43, n. 11, p. 4101-4107, 1995.

RAYLEIGH. On the pressure developed in a liquid during the collapse of a spherical cavity. Philosophical Magazine, v. 34, n. 1, p. 94-98, 1917.

RECCO, A. Estudo da obtenção e das propriedades dos filmes de TiN e TiN depositados sobre aços ferramenta AISI H13 e D2 nitretados e não nitretados. Tese (Doutorado) — Universidade de São Paulo, São Paulo, 2008.

RECCO, A.; LÓPEZ, D.; BEVILACQUA, A.; SILVA, F.; TSCHIPTSCHIN, A. Improvement of the slurry erosion resistance of an austenitic stainless steel with combinations of surface treatments: Nitriding and tin coating. Nitriding and tin coating. Surface and Coatings Technology, v. 202, n. 4-7, p. 993-997, 2007.

RHO, B. S.; HONG, H. U.; NAM, S. W. Analysis of the intergranular cavitation of nb-a286 alloy in high temperature low cycle fatigue using ebsd technique. Scripta Materialia, v. 43, n. 2, p. 167-173, 2000.

RICHMAN, R.; MCNAUGHTON, W. Correlation of cavitation erosion behavior with mechanical properties of metals. Wear, v. 140, n. 1, p. $63-82,1990$. 
ROTHERY, H. Estrutura das ligas de ferr. Introdução elementar. 1ra. ed. São Paulo: Edgar Blucher, 1968.

SARMA, G.; DAWSON, P. Effects of interactions among crystals on the inhomogeneous deformations of polycrystals. Acta Materialia, v. 44, n. 5, p. 1937 - 1953, 1996.

SCHWARTZ, A.; KUMAR, M.; ADAMS, B. Electron backscatter diffraction in materials science. first. New York: Kluwer Academic, 2000.

SHIMA, A.; TOMITA, T. K.; OHSAWA, N. Mechanism of impact pressure generation from spark-generated bubble collapse near a wall. AIAA Journal, v. 21, n. 1, p. 55-59, 1983.

SIMMONS, J. Overview: High-nitrogen alloying of stainless steels. Materials Science and Engineering a-Structural Materials Properties Microstructure and Processing, v. 207, n. 2, p. 159-169, 1996.

SINATORA, A. Custos e soluções para problemas de desgaste. Metalurgia e Materiais, v. 53, n. 467, p. 548-560, 1997.

SINATORA, A. Introduçaõ ao processo de desgaste. 2000.

SOYAMA, H.; MACODIYO, D. Fatigue strength improvement of gears using cavitation shotless peening. Tribology Letters, v. 18, n. 2, p. 181-184, 2005.

SOYAMA, H.; SASAKI, K.; ODHIAMBO, D.; SAKA, M. Cavitation shotless peening for surface modification of alloy tool steel. Jsme International Journal Series a-Solid Mechanics and Material Engineering, v. 46, n. 3, p. 398-402, 2003.

SPIDEL, M. Properties and aplications of high nitrogen steels. HNS88-High Nitrogen Steels- Institute of Metals,, London, p. 92-96, 1989.

STECK, B.; SOMMERFIELD, G.; SCHNEIDER, V. Cavitation on Wet Cylinders Liners of Heavy Duty Diesel Engines. 2006. SAE Technical Paper Series.

TAYLOR, G. Plastic strain in metals. Journal of the Institute of Metals, v. 62, n. 1, p. 307-324, 1938.

TOMITA, Y.; SHIMA, A. High-speed photographic observations of laser-induced cavitation bubbles in water. Acustica Journal, v. 71, p. 161-171, 1990.

TORO, A. Microestrutura e propriedades de superfície de aços inoxidáveis martensíticos de alto teor de nitrogênio. Tese (Doutorado) — Universidade de São Paulo, São Paulo, 2001.

TORO, A.; MISIOLEK, W.; TSCHIPTSCHIN, A. Correlations between microstructure and surface properties in a high nitrogen martensitic stainless steel. Acta Materialia, v. 51, n. 12, p. 3363-3374, 2003.

TORO, A.; TSCHIPTSCHIN, A. Chemical characterization of a high nitrogen stainless steel by optimized electron probe microanalysis. Scripta Materialia, n. doi:10.1016/j.scriptamat.2010.06.021, 2010.

TSL-INC. Oim analysis for windows. TexSEM laboratories-USA, 2003. 
UYN, D. L.; HUDD, R. Steels: Metallurgy and Applications. Boston, edition = 3ra,: Butterworth-Heinemann, 2000.

VIANA, C.; PAULA, A. Texturas de deformação. II workshop sobre textura e relações de orientação- Escola Politécnica da USP, São Paulo, p. 35-54, 2003.

WANTANG, F.; YANGZENG, Z.; XIAOKUI, H. Resistance of a high nitrogen austenitic steel to cavitation erosion. wear, v. 249, p. 788-791, 2001.

WRIGHT, S.; FIELD, D. Recent studies of local texture and its influence on failure. Materials Science and Engineering a-Structural Materials Properties Microstructure and Processing, v. 257, n. 1, p. 165-170, 1998.

ZHOU, Y. K.; HAMMITT, F. G. Cavitation erosion incubation period. wear, v. 86, p. 299-313, 1983.

ZUM-GAHR, K. Microstructure and wear of materials. First. Amsterdam: Elsvier, 1987. 